University of Rhode Island

DigitalCommons@URI

Open Access Master's Theses

1992

\title{
Evaluation of Potential Wildlife Habitat in Created and Restored Freshwater Wetlands in Selected New England States
}

Staci Rae Holcombe

University of Rhode Island

Follow this and additional works at: https://digitalcommons.uri.edu/theses

\section{Recommended Citation}

Holcombe, Staci Rae, "Evaluation of Potential Wildlife Habitat in Created and Restored Freshwater Wetlands in Selected New England States" (1992). Open Access Master's Theses. Paper 758.

https://digitalcommons.uri.edu/theses/758

This Thesis is brought to you for free and open access by DigitalCommons@URI. It has been accepted for inclusion in Open Access Master's Theses by an authorized administrator of DigitalCommons@URI. For more information, please contact digitalcommons-group@uri.edu. 
EVALUATION OF POTENTIAL WILDLIFE HABITAT IN CREATED AND RESTORED FRESHWATER WETLANDS IN SELECTED NEW ENGLAND STATES

BY

STACI RAE HOLCOMBE

A RESEARCH PROJECT SUBMITTED IN PARTIAL FULFILLMENT OF THE REQUIREMENTS FOR THE DEGREE OF MASTER OF COMMUNITY PLANNING

UNIVERSITY OF RHODE ISLAND

SPRING 1992 
MASTER OF COMMUNITY PLANNING RESEARCH PROJECT

OF

STACI RAE HOLCOMBE

Approved:

Major Professor

Acknowledged:

Director

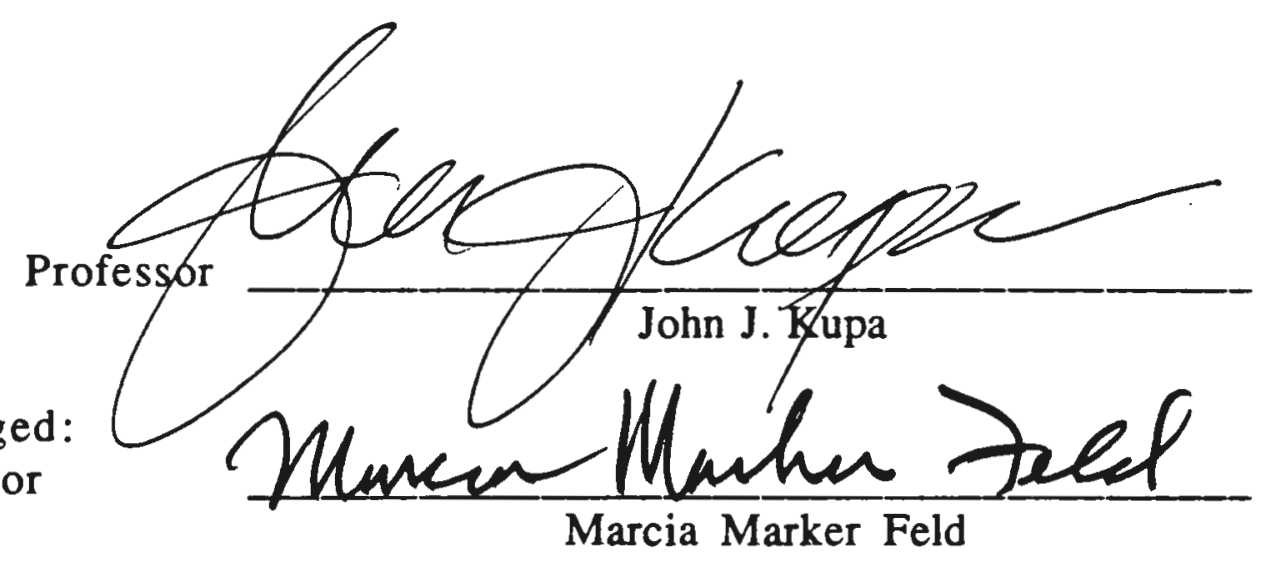




\section{ABSTRACT}

In the past, wetlands were considered to be a nuisance. They were thought of as sources of mosquitoes and places of disease. The environmental awakening of the late 1960's and early 1970's changed the negative view of wetlands and brought about a host of wetland protection laws, programs, and agencies directed toward wetland protection.

Today, many of the wetland protection legislations (e.g., Section 404 of the Clean Water Act, the Massachusetts Wetlands Protection Act, etc...), require a permit to alter a wetland. In efforts to stop any further net loss of wetlands, regulating agencies are allowing permit applicants to create or restore wetlands, as mitigation for wetland losses due to their projects, if there are no other practical alternatives.

These created and restored wetlands are the subject of this research project. The artificial wetlands are intended to compensate for wetland loss by replacing the natural wetlands. However, if the created and restored wetlands do not perform the same functions as the original wetland, then they are not sufficiently replacing the natural wetlands. If this is the case, then the wetland protection laws that allow this type of mitigation may not be fulfilling their purpose and natural wetlands may not be adequately protected.

This project will evaluate the potential wildlife habitat of created and restored wetland projects and compare it to that of natural, undisturbed wetlands to determine if artificial wetlands in New England are adequate replacements for natural wetlands. 


\section{ACKNOWLEDGEMENTS}

I wish to thank my advisor, John J. Kupa, for his guidance and helpful criticisms during the writing of this study. He has helped me to better understand wetlands and the environment in general.

I would also like to thank Kyla Bennett, of the U.S. Environmental Protection Agency, Region 1. She was the one who encouraged me to attempt this project. She always had time to give me suggestions, edit this document, and answer my endless questions. I sincerely thank her for her unfailing support.

Many special thanks go to all those who patiently answered my many questions, including all the members of the Wetland Protection Section at the Environmental Protection Agency, Region 1, and Frank Smigelski, of the New England Branch of the U.S. Corps of Engineers. They were all of great assistance to me in my quest to find wetland sites to evaluate.

I would especially like to thank my fiance, David Hulseberg, for trudging through the mucky wetland sites with me on all those hot and humid summer weekends. I thank him for his endless support, recommendations, gasoline, and especially patience on all those long trips. He was always ready to lend a hand, offer advice, or just listen. He has helped me to get through this with a smile on my face.

Finally, I would like to thank my mother, Remegia Holcombe, for her constant encouragement. She always understood when I had to break engagements with her to work on this immense project. She always had confidence in me, even when I had none of my own. Without her support, I could not possibly have come this far. 


\section{TABLE OF CONTENTS}

Page

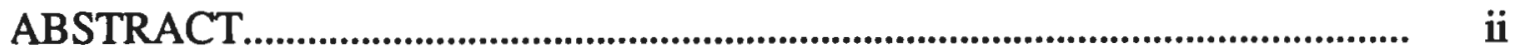

ACKNOWLEDGEMENTS........................................................................................ iii

LIST OF TABLES........................................................................................ vi

LIST OF MAPS................................................................................................ vii

\section{Chapter}

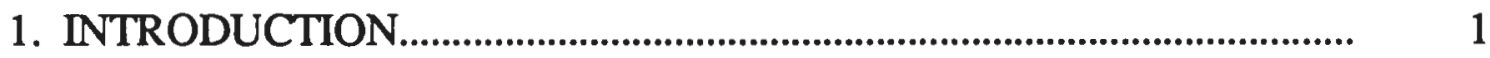

Background........................................................................................ 2

Statement/Significance of the Problem to be Addressed....... 4

2. WETLAND DEFINITION, TYPES, AND VALUES................................. 6

Definition of a Wetland..................................................................... 7

Wetland Types............................................................................................... 9

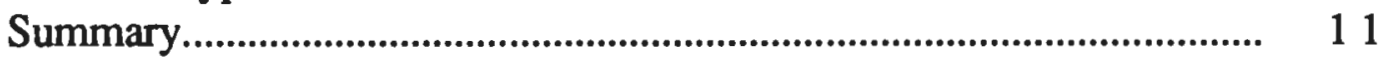

Wetland Values......................................................................................... 11

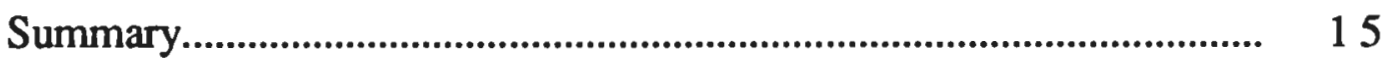

3. WETLAND PROTECTIVE LEGISLATION......................................... 16

Federal Protection Mechanisms...................................................... 18

State Protection Mechanisms........................................................ 23

Summary..................................................................................... 26

4. RESEARCH HYPOTHESIS.................................................................. 27

Is Wetland Creation Successful?..................................................... 29

Summary................................................................................................ 32

5. METHODS OF ANALYSIS............................................................. 33

Wetland Comparison............................................................................. 35

Procedure of Analysis.................................................................. $\quad 36$

6. SPECIFICATION OF DATA.......................................................... 39

Portsmouth High School Sites........................................................ 40

Bradgate Associates Sites......................................................... $\quad 50$ 


\section{TABLE OF CONTENTS cont.}

\section{Chapter}

6. SPECIFICATION OF DATA cont.

Rockingham Mall Sites.......................................................................... 57

Woonsocket Industrial Highway Sites....................................... 67

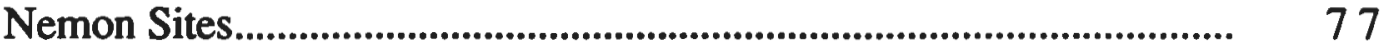

Signal/Resco Resource Recovery Facility Sites....................... 86

Cheshire Waste Water Treatment Plant Sites......................... 96

Robertson/Tomasso Nature Park Sites..................................... 106

Connecticut Route 7 Sites.................................................................. 117

Southbury Travel Center............................................................... 128

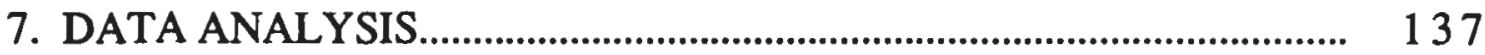

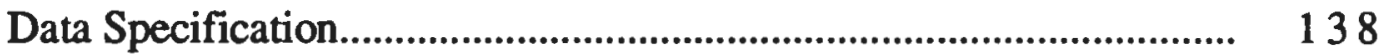

Data Calculations........................................................................... 141

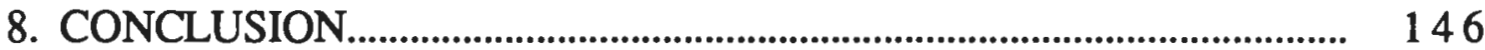

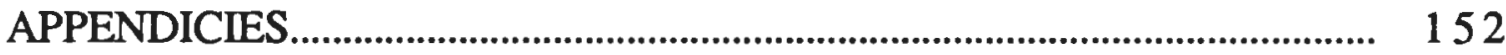

Appendix A (Field Sheets) ........................................................... 153

Appendix B (Permits)....................................................................... 254

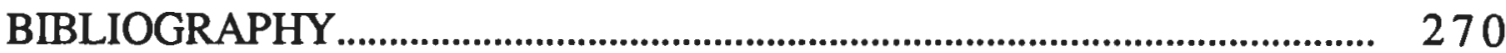




\section{LIST OF TABLES}

Page

Table

1. Summary of Two State Wetlands Programs................................ 25

2. Created and Restored Sites.................................................................... 37

3. Water Quality Classifications............................................................ 139

4. Site Specific Zoning Classifications....................................................... 140

5. Functional Value Indexes......................................................................... 142

6. Re-Calculated Functional Value Indexes........................................... 144 


\section{LIST OF MAPS}

Page

Map

1. Portsmouth High School-Site Location Map............................. 43

2. Portsmouth High School-Athletic Field Expansion Plan View.

3. Portsmouth High School-Mitigation Area Plantings.............. 46

4. Portsmouth High School-Created and Control Sites (US SCS Soils Map)................................................................................ 47

5. Portsmouth High School-Control Site (NWI Map).................... 49

6. Bradgate Associates-Created and Control Sites (USGS Topo Map-Nashua South Quad.)................................... 52

7. Bradgate Associates-Created and Control Sites (US SCS Soils Map)........................................................................ 54

8. Bradgate Associates-Mitigation Map.......................................... 55

9. Rockingham Mall-Created and Control Sites (USGS TopoSalem Depot Quad.)............................................................................. 60

10. Rockingham Mall-Created and Control Sites (US SCS Soils Map).

11a. Rockingham Mall-Southern Wetlands Creation Sites Planting Plan

11b. Rockingham Mall-Southern Wetlands Creation Sites Planting Plan.

12. Rockingham Mall-Control Site (NWI Map)............................. 65

13. Woonsocket Route 99-Created Site (USGS TopoPawtucket Quad.).

14. Woonsocket Route 99-Created Site (US SCS Soils Map)........ 72 


\section{LIST OF MAPS cont.}

$\underline{\text { Map }}$

15. Woonsocket Route 99-Mitigation Area Planting Plan........... 73

16. Woonsocket Route 99-Control Site (NWI Map)....................... 74

17. Woonsocket Route 99-Control Site (US SCS Soils Map)......... 76

18. Nemon-Restored and Control Sites (USGS Topo-Old Orchard Beach Quad.).................................................................... $\quad 80$

19. Nemon-Restoration Area Plan.................................................... 82

20. Nemon-Restored and Control Sites (US SCS Soils Map)........ 83

21. Nemon-Restored and Control Sites (NWI Map)..................... 85

22. Signal Resource Recovery Facility-Site Location Map.......... 89

23. Signal Resource Recovery Facility-Created Site (US SCS Soils Map)..................................................................................... 91

24. Signal Resource Recovery-Wetlands Mitigation Plan........... 92

25. Signal Resource Recovery-Proposed Compensatory Wetland.

26. Signal Resource Recovery-Control Site (NWI Map)............... 94

27. Cheshire WWTP-Created Site (USGS Topo-Meriden Quad.)

28. Cheshire WWTP-Created Site (US SCS Soils Map)................. 101

29. Cheshire WWTP-Proposed Dike and Wetland Areas........... 102

30. Cheshire WWTP-Mitigation Area Map................................. 103 


\section{LIST OF MAPS cont.}

Map

31. Cheshire WWTP-Control Site (NWI Map).................................. 104

32. Robertson/Tomasso Nature Park-Site Location Map............ 109

33. Robertson/Tomasso Nature Park-Created Site (US SCS Soils Map).

34. Robertson/Tomasso Nature Park-Area Context Map............ 112

35. Robertson/Tomasso Nature Park-Wetland Mitigation Plan.

36. Robertson/Tomasso Nature Park-Created and Control Sites (USGS Topo-New Britain Quad.).................................. 114

37. Robertson/Tomasso Nature Park-Control Site (NWI Map)

38. CT Route 7-Created Site (USGS Topo-Norwalk No. Quad)... 120

39. CT Route 7-Created Site (US SCS Soils Map)............................. 122

40. CT Route 7-Created Site (Close-up Site Location Map)........ 123

41. CT Route 7-Created Site-Mitigation Planting Plan................. 124

42. CT Route 7-Control Site (NWI Map)............................................. 125

43. CT Route 7-Control Site (US SCS Soils Map).............................. 127

44. Southbury Travel Center-Restored Site (USGS TopoSouthbury Quad.)....................................................................... 131

45. Southbury Travel Center-Wetlands Restoration Plan.......... 133 
LIST OF MAPS cont.

$\underline{\text { Map }}$

Page

46. Southbury Travel Center-Restored and Control Sites

(US SCS Soils Map)........................................................................ 134

47. Southbury Travel Center-Control Site (NWI Map).............. 135 
Chapter One

\section{INTRODUCTION}




\section{Chapter One}

\section{INTRODUCTION}

\section{Background}

During the Ice Age, about twelve thousand years ago, the glaciers carved valleys, rivers, and lakes into the North American landscape. Shortly after, these waterbodies began to naturally evolve into the freshwater wetlands. (Mitchell, 1975). Through succession, all open bodies of water eventually become wetlands “. . . because all lakes and ponds are transitory, remaining open no longer than it takes geological and biological forces to transform them" (Mitchell, 1975: 1-2).

In the past, humans considered wetlands as a nuisance. They were thought of as places of disease, unpleasant odors, and as sources of mosquitoes and flies. "In 1868, the Massachusetts legislature passed an act providing for the "abatement of wet, rotten, or spongy land covered with stagnant water" (US EPA, February 1987: 3). Unfortunately, these efforts were successful. As a result of this negative perspective, much of the wetlands in the United States have been destroyed. Replacing them are agricultural lands and developments. Some are even used for receptacles of household and hazardous waste. (EPA, February 1988). It is reported that the United States has lost over fifty percent of its natural wetlands in the past 200 years, (Dahl, 1990). 
Draining, filling and converting wetlands in the United States began shortly after the European settlers arrived. In the 1800's, the federal government portioned out nearly 65 million acres of wetlands to 15 states under the Land Swamp Acts. However, the most drastic conversion occurred in the 200 year span between the mid-1950's and mid-1970's. During this period, approximately 450,000 acres of wetlands were lost per year. Ninety percent of inland wetlands were lost to agriculture. (Baldwin, September 1987).

Within the past few decades, environmental awareness regarding wetlands has increased. This is evidenced by the many new laws, wetland protection mechanisms, and agencies that have surfaced whose objective is to preserve wetlands. With an increased understanding of the ecological processes of wetlands, attitudes have changed toward wetlands. Now efforts are to protect, not drain and fill wetlands. However, there is still great pressure from those wishing to convert the wet areas to developed or agricultural lands. In efforts to achieve no further net loss of wetlands, federal and state governments are requiring mitigation for their loss. As mitigation for wetlands being destroyed in these conversion efforts, there is a new idea that has sparked attention; wetland creation ${ }^{1}$ and restoration ${ }^{2}$.

This study examines the quality of wetland creation and restoration projects in every New England state, except Vermont (no

1 Wetland creation, as used in this study, will denote an attempt, by humans, to make a wetland that simulates a natural wetland, in an area where a wetland has not previously existed.

2 The term wetland restoration in this paper is used to denote the creation of a wetland in an area where a wetland previously existed. 
site data could be obtained for this state). This study will examine the potential wildlife habitat of created/restored wetlands and compare it to that of natural wetlands in New England.

\section{Statement/Significance of the Problem to be Addressed}

Wetlands management and protection have recently become issues in the planning world. The creation and restoration of wetlands as compensation for altered or destroyed natural wetlands is a new issue that must be faced by all planners.

Attempting to create or restore a wetland may be difficult. One scientist states that there is not much scientific foundation supporting the fact that wetland replication ${ }^{3}$ will replace lost wetland functions, (Larson, 1987). Thus, it is possible that replication of a natural wetland that was created through natural succession over many decades is impossible.

Of the many laws and statutes that attempt to protect wetlands, most require a permit for any party to 'alter' a wetland. If a permit is granted, depending on the size and permanence of the 'alteration,' the reviewing agencies usually require compensation for the altered or destroyed wetland. This compensation is usually in the form of cash, land donation, or increasingly more often, in the creation or restoration of another wetland. Thus, wetlands are created by humans to replace the natural wetlands destroyed by humans.

3 The term replication in this paper will be used to denote wetlands that are created or restored as mitigation for altering natural wetlands. 
With the sprawl of our cities, prime land for development is becoming scarce. As the pressure for economic expansion increases, lands previously thought to be too difficult to develop due to natural features are now getting a second look. “As development moves into more marginal parcels of land, the presence of wetlands becomes more likely" (Smith, 1989). In increasing numbers, developers are applying for permits, attempting to overcome the obstacles presented by these natural features. This has resulted in an increase in the creation and restoration of wetlands around the country as mitigation for those destroyed by permitted activities. The quality of these created and restored wetlands is the topic of this research project.

Knowledge of issues concerning wetland mitigation are key issues to planners. Planners should be aware of the federal, state, and local laws that allow creation and restoration as compensation for altering wetlands. Awareness of this legislation and its impacts on the environment and future economic development within a community are critical to planners, especially when balancing long term goals for both urban development and environmental protection. 
Chapter Two

\section{WETLAND DEFINITION, TYPES AND VALUES}




\section{Chapter Two}

\section{WETLAND DEFINITION, TYPES AND VALUES}

\section{Definition of a Wetland}

Federal, state and local governments often have different definitions of wetlands, each using different criteria to delineate wetland/upland boundaries. Hence, for the purpose of this study, it will be essential to set a common definition of a wetland.

There is no one universally accepted definition for a wetland. The definitions vary from state to state and government agency to government agency. The U.S. Fish and Wildlife Service has their own definition, the U.S. Environmental Protection Agency (EPA) and the U.S. Army Corps of Engineers (COE) have another, many states have their own definitions, and the student biology books have yet another.

For example, Connecticut distinguishes freshwater wetlands by their soils and coastal wetlands by their vegetation. The freshwater definition reads: "Freshwater wetlands are areas such as banks, bogs, swamps, meadows and submerged land. Soil types designated as poorly drained, very poorly drained, alluvial and flood plain by the National Cooperative Soils Survey define inland (freshwater) wetlands for regulatory purposes" (US EPA, May 1981). 
On the other hand, in Massachusetts, the wetland definition relies on the presence and duration of water, and the location in relation to inland water. It reads as follows:

Freshwater Wetlands are defined as wet meadows, marshes, swamps, bogs; and areas where groundwater, flowing or standing surface water, or ice provides a significant part of the supporting substrate for a wetland plant community for at least five months of the year. Freshwater wetlands are also defined as emergent and submergent plant communities in inland waters and that portion of any bank which touches any inland waters (Mass. Gen. Laws Ch. 131, $\$ 7$, para. 7).

Federal agencies also have different definitions of wetlands. For example, for regulatory purposes, the EPA and the COE use a definition created in response to Section 404 of the Clean Water Act of 1977. This definition does not include lakes ponds and rivers as wetlands, and excludes similar areas that lack hydrophytic vegetation (Tiner, 1989). The definition reads as follows:

Those areas that are inundated or saturated by surface or ground water at a frequency and duration sufficient to support, and that under normal circumstances do support, a prevalence of vegetation typically adapted for life in saturated soil conditions. Wetlands generally include swamps, marshes, bogs and similar areas (EPA, 40 CFR 230.3 and CE, 33 CFR328.3).

On the other hand, the definition used by the U.S. Fish and Wildlife Service is a more scientific description. It is used more by federal agencies for technical classification (US EPA, February 1987). It reads as follows:

Wetlands are lands transitional between terrestrial and aquatic systems where the water table is usually at or near the surface or the land is covered by shallow water. For purposes of this 
classification wetlands must have one or more of the following three attributes: (1) at least periodically, the land supports predominantly hydrophytes; (2) the substrate is predominantly undrained hydric soil; and (3) the substrate is nonsoil and is saturated with water or covered by shallow water at some time during the growing season of each year (Cowardin, et al, 1979).

Different definitions of wetlands lead to different delineations of wetland/upland boundaries. Thus, it is important that the same definition that is recognized in the New Hampshire Method (the method used to evaluate wetlands in this study), is also the same that is recognized by this study. Both the State of New Hampshire and the New Hampshire Method recognize the EPA/COE definition. Thus, the same definition is chosen for this study.

\section{Wetland Types}

From ponds to bogs, there are many different types of wetlands. A few of these wetland types will be explained, focusing specifically on the three most common freshwater wetlands: marshes, swamps, and bogs.

Inland freshwater marshes are common in New England and usually have water depths from a few inches to three feet. These include marshes, river oxbows, wet meadows, and the borders of many lakes and ponds. The water sources for these types of wetlands are typically groundwater, springs, ponds and rivers, rainfall, and surface runoff (US EPA, February 1987).

Marshes usually begin as a shallow depression in a drainage system. Often they have a slow current flowing through them. They are characterized by vegetation with soft-stems, such as cattails 
(Typha latifolia), grasses, sedges (Dichromena colorata), arrowheads (Sagittatria latifolia), and bullrushes (Juncus effusus). These plants can grow on moist soil, or partially submerged in water, or they may bind their roots together to form a floating colony (Howland, 1989: 20). "Bottom materials are a mix of organic/mineral silts and sediments. As the water level fluctuates and this organic base slowly reaches to and above the average water level, populations of shrubs and trees begin to establish themselves, and the transition from open marsh through shrub swamp to wooded swamp begins" (US EPA, May 1981).

Swamps are forested or shrub areas. The soil is very wet throughout most of the year. However, they may have no standing water at all at certain times during the year (US EPA, February 1987). These wetlands usually get their water from surface runoff or from the flooding of ponds or streams. Common trees found in swamps include: cedar (Camaecyparis thyoides), red maple (Acer rubrum), willows (Salix), alders(Alnus), dogwoods (Cornus stolonifera), blueberry (Vaccinium corymbosum), and buttonbush (Cephalanthus occidentalis).

Bogs are less common in New England, though they do exist here. The high acidity of their peat soils result in unique vegetation and wildlife that have adapted to the harsh conditions. Bogs usually form in depressions that are poorly drained. The spongy vegetative covering of sphagnum moss or sedge are characteristic of this wetland (US EPA, February 1987). Typical shrubs of the bog include: leatherleaf (Chamaedaphne calyculata), cranberry (Vaccinium macrocarpon), and bog laurel (Kalmia angustifolia). 


\section{Summary}

The above types of wetlands only constitute a few of the many wetland types that can be found in the world. However, they are the types that were encountered in the field studies for this project. In this study the potential wildlife habitat of created and restored wetlands of one type will be compared to that of natural, undisturbed wetlands of a similar. This evaluation will indicate if created/restored wetlands are sufficient replacements for natural wetlands in New England. The study was only carried out in five of six New England states (Vermont was excluded because no site data could be located for the state).

\section{Wetland Values}

Wetlands of all types provide many unique benefits, or values, in their natural condition. The type of wetland and quality of the natural ecosystem can determine how many values are present. Thus, it is plausible that created wetlands will not provide the same beneficial values that natural wetlands provide because it is difficult, if not impossible, to recreate all the intricate pieces of a wetland ecosystem.

Different states and federal government agencies may recognize a different number of wetland values. However, for the most part they are similar. They can include:

\section{Flood and Storm Protection}

Wetlands are critical in protecting shorelines and downstream areas from flooding, waves, and storm flow. They tend to act like a tubs by storing floodwaters (Tiner, February 1988). Flood storage 
occurs when peak flows of surface water or groundwater are slowed by a wetland basin (US EPA, February 1987). By slowing the velocity of the waters, the wetlands protect adjacent properties from flooding. After wetlands slow and store the water, they slowly release it downstream.

\section{Fish and Wildlife Habitat}

It is widely recognized that wetlands provide valuable wildlife habitat, (US EPA, February 1987). “Inland freshwater wetlands adjacent to rivers and lakes provide valuable nesting and brood habitat for wood ducks, hooded mergansers, and black ducks. These wetlands are also prime habitat for furbearers, such as beaver, muskrat, river otter, and mink. Eastern painted turtles, bog turtles, and snapping turtles are found in the region's freshwater wetlands, as are the American bittern, marsh wren, red-winged blackbird, swamp sparrow, and song sparrow" (U.S. Fish and Wildlife Service, 1989: 4-5).

Some animals, such as the wood duck (Aix sponsa) and muskrat (Ondatra zibethicus), are dependent on wetland ecosystems as their sole suitable habitat (Tiner, February 1988). However, to other animals, wetlands provide a portion of habitat necessary for their survival. For example, deer and moose may just use wetlands for the food and water.

Wetlands may also provide habitat to federally endangered, threatened or rare species. "More than one-third of the nation's threatened and endangered plant species and one-half of the animal species are wetland-dependent. Many Federally and State-listed 
species are associated with the wetlands of the northeastern United States" (US Fish and Wildlife Service, 1989: 5).

\section{Erosion Control}

When wetlands are found between water and upland, they can protect the uplands from erosion. "Wetland vegetation can reduce shoreline erosion in several ways, including increasing durability of the sediment through binding with its roots; dampening waves through friction; and reducing the velocity of the current through friction" (Burke, et. al, 1988: 5). Thus, wetland vegetation helps protect not only uplands, but shorelines from erosion. In some states, wetland vegetation has been planted to control erosion (Burke, et. al., 1988: 5).

\section{Water Quality Improvement}

Since wetlands are usually located in between land and water, they also perform a very important task; the filtering of water. Water is filtered as it moves through the wetland, thus improving the quality of the water. Wetlands also increase water quality by removing and retaining nutrients, reducing sediments, and processing chemical and organic wastes. (Tiner, 1989: 55).

Wetland plants are important in most of the water purification process. For example, the wetland plants trap excess sediments and absorb overabundant nutrients such as nitrogen and phosphorus. Wetland plants have also been shown to remove waste products from water. "In fact, certain wetland plants are so efficient in this task that some artificial waste treatment systems are using these plants" (Burke, et. al, 1988: 7). 


\section{Natural Products}

Wetlands can serve as vast resources for some natural products. The harvest of these natural resources has resulted in local economic prosperity. For example, timber, fish, wildlife, peat, animal furs, blueberries, cranberries, and wild rice are all found in wetlands. Wetland grasses are dried and used as food for livestock (Burke, et. al., 1988: 6). In addition, most of the nation's shellfish species are wetland dependent in some way. "For example, in the Southeast, 96 percent of the commercial catch and over 50 percent of the recreational harvest are fish and shellfish that depend on the estuary-coastal wetland system. Each year, the U.S. commercial fisheries harvest is valued at more than $\$ 10$ billion." (US EPA, February 1988: 5).

\section{Water Supply and Groundwater Recharge}

Many wetlands are valuable for their groundwater discharge. On occasion, groundwater discharge may provide enough water for public use. In Massachusetts, at least 60 communities have public wells in or near wetlands. (Burke, et. al, 1988: 6).

Surface water recharge to groundwater from wetlands is not very common. However, when it does occur, it can be valuable to drinking water supplies, especially when a wetland is over an aquifer (US EPA, February 1987). Whether or not groundwater recharge occurs depends on a number of factors, including: wetland type, geographic location, season, soil type, water table location, and precipitation (Tiner, September 1989: 63). 
Recreation and Aesthetics

Many recreational activities take place in wetlands. Opportunities exist for hiking, picnicking, boating, swimming, hunting, fishing, and ice skating. There are also ample opportunities to take advantage of the scenic beauty found in wetlands. Some may enjoy painting, photography, bird watching, and nature observation in wetlands (Burke, et. al., 1988: 7). Wetlands also provide an environment for the education of students and for scientific research. Summary

The above listed values are only a few of the many known values of wetlands. However, this list has shown that marshes, swamps and other wetlands are assets to society in their natural state. They provide recreational opportunities, natural resources for human use, protect property from floods, and increase water quality (Tiner, September 1989: 64).

However, not all wetlands have every value listed above. It is often difficult to detect if some of the values are present in wetlands, or measure how well they function. Thus, for the purposes of this study, one wetland value was chosen to be measured. This value, wildlife habitat, was found to be the easiest to measure and was expected to be present in nearly all the New England wetlands studied. 
Chapter Three

\section{WETLAND PROTECTIVE LEGISLATION}




\section{Chapter Three}

\section{WETLAND PROTECTIVE LEGISLATION}

As an offshoot of this study, the effectiveness of wetland protection legislations will be examined. If this study determines that the created/restored wetlands are not fulfilling the values of the natural wetlands, then it is possible that there may be a problem with the legislations that are supposed to be protecting wetlands. Thus, a brief look at the wetland protection mechanisms will be valuable here.

There is no one mechanism that is comprehensive enough to fully protect wetlands (US EPA, November 1988). "Because no omnibus wetlands protection law currently exists in the United States, wetlands are protected piecemeal through a variety of federal, state, and local policies, programs and regulations" (Pontius, 1990: 12). Since this is the case, it will be important to describe both the state and federal levels of protection below.

A variety of protection mechanisms exist, both for freshwater and coastal wetlands. However, since this study focuses only on freshwater wetlands, only those legislations affecting freshwater wetlands will be discussed. 


\section{Federal Protection Mechanisms}

\section{The National Environmental Policy Act of 1969}

In December of 1969, the U.S. Congress passed the National Environmental Policy Act (NEPA). This act, created to reconcile conflicts between economic growth and environmental protection, was the beginning of "the environmental decade" (Salvesen, 1990). NEPA requires all federal agencies to be sensitive of the environment and consider the impacts on it when making major federal actions.

This act requires that an Environmental Impact Statement (EIS), be completed by all federal agencies when they are making major federal actions significantly affecting the quality of the human environment. The EIS includes an intense environmental analysis which studies the impact of the action, the adverse environmental effects that cannot be avoided, and any alternatives to the action (Salvesen, 1990).

An EIS is usually only required for significant projects. However, they may also be triggered by the value of the natural resource affected and the amount of controversy (Salvesen, 1990). Smaller projects with little adverse effects on the environment usually only require an Environmental Assessment (EA). An EA is a shorter, less-detailed version of an EIS.

Thus, in major projects that will affect natural resources, such as wetlands, NEPA requires that an EIS be completed. An EIS will assist in identifying the valuable resources that will be affected by the project. Federal, state, and local government can then focus on avoiding or mitigating the impacts on the environment. In doing so, NEPA helps to protect the entire environment, wetlands included. 


\section{Section 404. Clean Water Act}

In 1972, the U.S. Congress amended the original Clean Water Act (originally called the Federal Water Pollution Control Act) to include Section 404. This section of the Act is now the strongest federal protection for wetlands (Smith, 1989). This act prohibits the discharge of dredged or fill materials into U.S. navigable waters. "Subsequent regulatory and legal actions extended the section 404 permit program authority beyond navigable waters to encompass "waters of the United States," which were defined as all surface waters and their tributaries" (Pontius, 1990: 14).

Both the U.S. Environmental Protection Agency and the U.S. Army Corps of Engineers jointly administer the program. The U.S. Fish and Wildlife Service and the National Marine Fisheries Service advise and comment on the 404 process (Burke, et. al., 1988: 19).

According to Section 404, permits are necessary to alter or discharge material into wetlands. These permits may only be granted by the U.S. Army Corps of Engineers. The COE has the authority to determine if the permit should be issued based on compliance with the $404(\mathrm{~b})(1)$ guidelines. These guidelines state that the applicant must show that the proposed action is the least environmentally damaging practicable alternative. However, the EPA has veto power over any decision made by the COE.

In 1977, Congress amended the Clean Water Act again and added some new sections. These involved: 1) the ability for the regulatory agencies to transfer authority to administer the program to individual states, 2) the provision for certain activities with minimal impact to be exempted from the program, and 3 ) the 
creation of general permits for activities with minimal individual or cumulative impact on wetlands (Pontius, 1990).

The two administering agencies of Section 404 of the Clean Water Act, the EPA and the COE, require that the applicant must first try to avoid, then minimize the impacts on wetlands in their project. If wetlands will still be altered due to the project, the EPA and the COE require that the impacts on wetlands be mitigated. As compensation for the wetland loss, wetlands are either created, preserved 4 , enhanced 5 , or restored. The amount of compensation is equal or greater to the amount of wetland loss. In compensating for wetland loss in this way, it appears that there is no net loss of wetlands due to the project. However, if the created wetlands are not functioning as natural wetlands by performing functions that the destroyed wetlands performed, then they are not sufficient replacements for the natural wetlands and net loss is still occurring. Rivers and Harbors Act of 1899

This regulatory program is also administered by the COE. Section 10 of this Act also requires a permit to dredge or place fill in the navigable waters of the United States. "Section 10 coverage extends only to traditionally navigable waters but is, in large measure, coextensive with Section 404 [of the Clean Water Act] coverage" (Salvesen, 1990: 9). Section 404 of the Clean Water Act is

\footnotetext{
4 Wetland preservation is usually accomplished by adding a covenant to the property deed where the wetland lies. The property owner gives up the opportunity to alter or convert the wetland in the future. This action ensures that the wetland will remain in its natural state indefinitely.

5 Wetland enhancement, as used in this study, is increasing the quality of one or more values of a wetland, (e.g., wildlife habitat for wood ducks is increased by locating places for them to nest in wetlands).
} 
much more encompassing than Section 10 of the Rivers and Harbors Act because it regulates all waters of the United States, including most wetlands, rather than just navigable waters.

Executive Orders

Order 11988 was released in 1977. This Order requires all federal agencies to avoid undertaking funding or permitting actions within the 100-year floodplain whenever possible (Salvesen, 1990). Order 11990, also released in 1977, requires all federal agencies to avoid undertaking any activities which may have an adverse impact on any wetlands (Salvesen, 1990).

National Flood Insurance Program

This program requires that communities control development within the 100-year floodplain. Communities are expected to restrict structures in the floodplain, especially those that will increase flooding downstream. This Program encourages communities to protect valuable environmental areas, including nontidal wetlands (Salvesen, 1990: 18).

\section{Food Security Act of 1985}

This Act creates a conservation reserve. Highly erodible lands that are taken out of crop production for ten to fifteen years are placed into this reserve. The Act also allows property easements to be taken from land owners who default on FmHA loans, if the property includes fish and wildlife habitat, floodplains, prime forestlands, erodible lands, or lands with high water quality. These easements are transferred to local governments or non-profit organizations for conservation purposes (Salvesen, 1990: 18). 


\section{Section 1221 of the Food Security Act of 1985}

This section is known as the "swamp buster" provision of the Food Security Act. It uses economic sanctions to limit destructive actions that can impact wetlands. This section prohibits the payment of federal benefits to anyone who converts a former wetland to dry land for agricultural use, thus removing agricultural subsidies and loan guarantees when wetlands are converted (Salvesen, 1990).

\section{Water Resources Development Act of 1986}

This Act requires that compensation for wetland losses be completed at the same time as the construction of the project. It also authorizes the COE to assess corrective mitigation for past wetland losses, without permission from Congress, up to $\$ 30$ million annually. If the action is not for the national benefit, then mitigation costs must be matched by 25 percent local or non-federal funds (Salvesen, 1990: 18).

\section{Tax Reform Act of 1986}

Under this act, landowners receive a strong incentive if they donate a conservation easement. This incentive is in the form of a tax benefit. "An easement for a wetland area would restrict the donor's rights in perpetuity to develop the wetland area" (Salvesen, 1990: 58). These gifts to the community are recorded on the deed as permanent covenants. These covenants can be very valuable in protecting wetlands.

The federal wetland protection mechanisms, as described above, overlap with state and local programs. Together, they help to preserve wetlands in the United States. Thus, state programs should also be examined. 


\section{State Protection Mechanisms}

There are many different mechanisms which can protect wetlands on the state level. State programs in New England usually protect wetlands above and beyond the federal programs. Very few states other than those in New England have fresh water protection laws. New England is unique in this respect. "Unlike Section 404 of the federal Clean Water Act, which regulates both tidal and nontidal wetlands, state regulatory laws have tended to differentiate between tidal and nontidal wetlands, with the former receiving far greater protection" (Burke, et. al., 1988: 21).

However, it is not within the realm of this study, nor is it feasible to evaluate every state's wetland protection mechanisms. Thus, for the purposes of this project, only two of the five New England states that were encountered in this project will be discussed. They are Massachusetts and Rhode Island. In addition, since this study deals solely with freshwater wetlands, only the aspects of the laws that deal with freshwater wetlands will be described.

\section{Massachusetts}

Massachusetts was the first state to adopt a wetlands protection law. The Jones Act of 1963 was Massachusetts' first state wetland law, though it only regulated coastal wetlands. The Hatch Act followed in 1966, regulating the activities in inland wetlands. In 1972, the two acts were combined to create the Massachusetts Wetland Protection Act (Mass .Gen. Laws Ch. 131, Section 40). Salvesen (1990) states that this act is the strictest wetlands program in the nation. 
The wetland regulations identify four inland and eleven coastal areas that are subject to protection. "The state's program is unusual in that it establishes general performance standards for different types of resource areas. The act presumes that wetlands prove at least one of the following seven values: protection of 1) groundwater, 2) water supplies, 3) fisheries, and 4) land containing shellfish; and protection from 5) storms, 6) floods, and 7) pollution-in that these values are in the public interest" (Salvesen, 1990: 64).

In Massachusetts, the legislation is unique in that it is administered at the local level by Conservation Commissions. If the community does not have a Conservation Commission, then the mayor will administer the program. If there is no one at the local level to administer the program, the the Massachusetts Department of Environmental Protection will administer it at the state level. Permits, issued by the local authorities, are required for any activity which will fill, dredge, remove or alter any bank, marsh, meadow, swamp, bog, creek, river, stream, pond, lake, or any area subject to flooding. Generally, these activities are regulated within 100 feet from any of the resources mentioned above.

Massachusetts usually receives approximately 6,000 permit applications each year. Very few are denied. In 1987, the state experienced a development boom. During this year, about 10,000 applications were received (Salvesen, 1990: 65). Mitigation typically required in Massachusetts is a 1:1 ratio.

Rhode Island

The legislation in Rhode Island regulates development in both coastal and freshwater wetlands. The legislation protecting the 
freshwater wetlands is called "The Fresh Water Wetlands Act" (as amended in 1971 and 1979), and is found in the Rhode Island General Laws Sections 2-1-18 to 2-1-27. The freshwater program is administered at the state level by the Rhode Island Department of Environmental Management (DEM). Activities in wetlands such as filling, dumping, daming, diking, diverting water, dredging, draining, altering, or excavating a wetland require a permit from DEM. If there is no other practical alternative for the project and wetlands must be altered, DEM requires mitigation.

In the past, the protection of freshwater wetlands in Rhode Island included only those swamps greater than three acres, marshes greater than one acre, all bogs, ponds greater than half an acre, rivers, areas subject to storm flow, areas subject to flooding, and upland areas within fifty feet of a wetland edge. However, recently, an "other" category was included into the legislation, giving control of all the state's wetlands to DEM.

A summary of the two state wetlands programs mentioned above can be seen in the table below:

\section{Table 1}

\section{SUMMARY OF TWO STATE WETLANDS PROGRAMS}

$\begin{array}{llll}\text { State } & \text { Legislative Authority } & \begin{array}{l}\text { Activities } \\ \text { Regulated }\end{array} & \begin{array}{l}\text { Admin. } \\ \text { Agency }\end{array} \\ \text { Massachusetts } & \begin{array}{l}\text { The Wetlands Protection } \\ \text { Act (1972) }\end{array} & \begin{array}{l}\text { Removal, fill } \\ \text { dredge, alter }\end{array} & \begin{array}{l}\text { Dept. of } \\ \text { Environ. } \\ \text { Protect. }\end{array} \\ & & & \end{array}$


Rhode Island The Fresh Water Wetlands Fill, dump, dam Dept. of Act (amended 1971 \&1979) dike, divert, Environ. dredge, drain, Mgmt. alter, excavate

Sources: Mass. Gen. Laws Ch. 131, Section 40 and

RI Gen. Laws, Sections 2-1-18 to 2-1-27

\section{Summary}

Thus, wetlands in the United States are protected by a variety of federal, state and local mechanisms. This study will determine if the creation and restoration of wetlands allowed by these laws (e.g., Section 404, Mass. Gen. Laws Ch. 131, Section 40 and RI Gen. Laws, Sections 2-1-18 to 2-1-27, etc...), are sufficient replacements for the natural wetlands. If they are not, then it will suggest that these wetland protection laws may not be comprehensive enough or do not meet their goals of preserving wetlands. 
Chapter Four

\section{RESEARCH HYPOTHESIS}




\section{Chapter Four}

\section{RESEARCH HYPOTHESIS}

Since wetlands are ecosystems that are created through natural succession over many years, it is unlikely that humans can replicate a wetland exactly. The issue of whether human-made wetland replicas are sufficient replacements for natural wetlands provides the foundation for the hypothesis of this research project. The purpose of this research project is to evaluate the hypothesis; wetlands created or restored by humans cannot be satisfactory replacements for natural wetlands.

To test this hypothesis, it was necessary to examine the quality of wetland creations and restorations and to compare natural wetlands to human-made wetlands. This study evaluated the potential wildlife habitat value of created/restored wetlands and compared it to that of similar type (e.g., forested, scrub-shrub, etc...), natural, undisturbed wetlands in five of the six New England states. This comparison is described further in Chapter Five, Methods of Analysis.

Other studies that conducted tests similar to the one in this study have determined that wetland creation is not successful and that created wetlands are not sufficient replacements for natural wetlands. Some of this literature is discussed below. 


\section{Is Wetland Creation Successful?}

Gwin and Kentula (1990) completed a report similar to this one for the US EPA that evaluated compliance of created wetlands in Oregon. This study compared ten created wetlands to the permits that were issued for them. The report found that cumulatively, the differences between what was described in the permits and what was actually built totaled a loss of 3.5 acres, or $29 \%$ of total wetland area that was specified to be created in the ten permits (Gwin and Kentula, 1990). "Losses of area occurred due to the differences between the permit conditions and the construction plans, often found in the same file. When the area of the wetland as-built was determined, it was often less than the area indicated in the construction drawings. Cumulatively, both discrepancies amounted to a loss of $29 \%$ of the wetland area that was to be created" (Gwin and Kentula, 1990: 23).

In an inter-agency memo at the US EPA - Region 1, it was stated that the rate of success of a wetland depends on the type of wetland that is being created (Shields, 1985). However, Krohe (1989) states that "we know very little about restoring wetlands, even though there is a lot of wetlands restoration going on" (Krohe, 1989: 4). Krohe goes on to explain that the Massachusetts policy guidelines on wetlands clearly state that no engineering solutions exist that can replicate a freshwater wetland. This is because creating habitats with such eccentric water regimes is tricky: if the hydrology is not right, then a wetland can not exist (Krohe, 1989). Even "...the Fish and Wildlife Service calls wetlands creation an experimental technology and insists that substituting artificial 
wetlands cannot justify [the] development of their counterparts" (Krohe, 1989: 7).

At the 1987 National Wetlands Policy Forum, it was explained that roughly half the restoration and creation projects created up until 1987 had failed in some respect. "The 1986 National Wetlands Symposium had heard much the same news; as a Massachusetts official told the symposium, many replicated wetlands were in fact only stormwater storage areas with a few wetland plants added" (Krohe, 1989: 7).

An article in The Boston Globe reported similar findings. A researcher reported of the wetland creations he had examined, "Most of them certainly didn't look good...They did not look like a natural system...You have a lot of mudholes in the name of replication ...For all the other functions of wetlands [other than waterfowl habitat], it's a crap shoot, just because you have cattails doesn't mean that you have a functioning site...[replication] is an art rather than a science" (Dumanoski, 1989: 25).

An authority on wetlands, Jon Kusler, also reports on the success of creation in a paper called "Wetland Restoration/Creation: A Science Perspective." Kusler explains that certain values of wetlands can be recreated with reasonable certainty, for example floodwater detention. However, he states that the scientific base is not complete enough to support assertions that the other values of natural wetlands can be created in artificial wetlands. In addition, Kusler believes that "based upon the limited studies of both intentional and unintentional restoration and creation projects to date, there is scientific consensus that no wetland can be duplicated 
or replicated exactly. Natural systems are far too complex for that. Most naturally occurring wetlands represent thousands of years of geologic and hydrologic processes..." (Kusler, 1987: 3).

A report done for the EPA by Reimold and Cobler (1986) shows similar results. In this study, 94 wetland replacement sites were evaluated on the basis of vegetative cover and wetlands size. Of that 94, 36 percent were unsuccessful while seven percent were marginal. Ten percent of the mitigation projects had not even been built, or had been destroyed by fill material (Reimold and Cobler, 1986). This study also discovered that "In some cases where unsuccessful projects were granted a COC [Certificate of Compliance], Conservation Commissions appeared satisfied by the fact that applicants had made a "good faith effort" to comply with...regulations" (Reimold and Cobler, 1986: 13).

Another concurrent view is described in the New York Times. In this article, it is reported that "More often than not, according to proliferating studies made by and for Federal and state governments ...efforts [at wetland restoration] are ending in failure. The failures not only threaten to undermine a highly advertised Federal and state goal of no further net loss of wetlands, they also jeopardize the hardwon credibility of wetlands restoration itself" (Stevens, 1991: pp C1).

Another wetlands expert focuses on how wetland mitigation should be evaluated in the future. "Larson (a wetland expert at the University of Massachusetts), states that "The test of whether replacement wetlands are a valid resource management practice is no longer a test of whether human-made wetlands will grow aquatic 
plants, attract ducks, or have the initial appearance of a natural wetland. The question to be answered is whether or not the artificial wetland will have a suite of ecological functions similar to those of the natural wetland it replaces"' (Kriz, 1988: 5).

\section{Summary}

In conclusion, many studies have examined the success of wetland creations and restorations. Most have determined that they are not successful. This indicates that low quality, human-made wetlands are not replacing the values of natural wetlands. This study examines a similar issue, the potential wildlife habitat of created and restored wetlands as compared to natural, undisturbed wetlands in New England. 
Chapter Five

METHODS OF ANALYSIS 


\section{Chapter Five}

\section{METHODS OF ANALYSIS}

Many methods to evaluate wetlands were considered for use in this project. One method was found to be particularly applicable. This method, Method for the Comparative Evaluation of Nontidal Wetlands in New Hampshire, was written by Ammann et. al. (1991). He modeled the method after a similar method that he created for the state of Connecticut called the "Method for the Evaluation of Inland Wetlands in Connecticut" (1986). According to a Wetlands Protection Specialist at the U.S. Environmental Protection Agency (EPA), the EPA and the U.S. Army Corps of Engineers are attempting to create a similar method, using the Connecticut and New Hampshire methods as models (Bennett, personal communication: 7/17/91).

The New Hampshire Method analyzes wetlands by their values. The Method is divided into fourteen sections, one for each of the values that the state of New Hampshire recognizes. Each section begins with a short introduction on the importance of that particular value. This is followed by a list of questions that should be answered in the field. These questions examine the different factors that contribute to the value. The answers to the questions are filled in on the data sheets, also provided in the section. Each possible answer to the questions has a number assigned to it. A few minor calculations at the end of the data collection yields a numerical value for each 
wetland. These numerical values can be used to compare one wetland to another.

The New Hampshire Method was chosen primarily for use in this project because it was designed for government officials, planners, and others who are familiar with wetlands, but who are not necessarily wetland experts. It was designed to assess local wetlands to determine which are the most valuable. In addition to being recommended to me by staff of the US EPA, it was also chosen for its simplicity.

If all of the worksheets in the manual are completed, the most valuable wetlands can be determined by the highest values. Thus, this method can be used to determine the "best" wetlands so they can be targeted for protection. However, in this study, the purpose is to compare created and restored wetlands to natural wetlands through one specific value that could be easily measured; potential wildlife habitat. If $i$ is determined that the human-made wetlands do not replace the wildlife value adequately, then it is highly possible that they do not replace other values adequately either.

\section{Wetland Comparison}

There are many ways that wetlands can be evaluated and compared. The federal government recognizes twelve values, and individual states may recognize many different values. Eight of those values have been listed above in Chapter Two. For the purposes of this project, it will not be feasible to measure every single value for every wetland sampled. Therefore, one value will be compared among all the wetlands: potential wildlife habitat. 
Through the evaluation of wildlife habitat of selected wetlands in New England, each created/restored wetland was compared to its natural counterpart. Specifically, wildlife habitat value was chosen for its ease of measurement. Since this researcher does not have formal training in wetland evaluation, the measurement of wildlife habitat appeared to be the most feasible.

To evaluate wildlife habitat, the habitat evaluation and ecological integrity sections of the Method for the Comparative Evaluation of Nontidal Wetlands in New Hampshire were followed. The data sheets were completed and relatively simple math calculations produced values which were used to compare the wetlands.

The values provided a basis to compare the wetlands to each other and ultimately to evaluate the hypothesis; wetlands created or restored by humans cannot be satisfactory replacements for natural wetlands. If this project determines the hypothesis is true, it may indicate that the wetlands in New England are adequately protected.

\section{Procedure of Analysis}

The first step of the study was to choose the ten created/restored sites in New England. These were chosen from the file drawers of the EPA - Region 1. Wetlands were chosen in five of the six New England states. Site specific information could not be located on any sites in Vermont. As much site specific information as possible was gathered from the files. The permits that were available can be found in Appendix B. Only human-made wetlands from two to five years old were chosen. 
The control sites were chosen next. These sites were the same type and of similar size as the artificial wetlands. The control sites were chosen within two miles of the created/restored wetland (with two exceptions). The ten chosen created/restored sites are listed in the table below:

\section{Table 2}

\section{CREATED/RESTORED SITES}

\section{$\underline{\text { Name }}$}

1. Portsmouth High School

2. Bradgate Associates

3. Rockingham Mall

4. Woonsocket Ind. Highway

5. Nemon

6. Signal Resource Recov.

7. Cheshire WWTP

8. Robertson/Tomasso Park

9. CT Route 7

10. Southbury Travel Center
Location

Portsmouth, NH 2

Nashua, NH 4

Salem, NH

Lincoln, RI

Saco, ME

Millbury, MA

Cheshire, CT

Plainville, CT

Norwalk, CT

Southbury, CT
Created/

Age $\quad$ Restored

2 Created

$4 \quad$ Created

2 Created

3 Created

3 Restored

$5 \quad$ Created

4 Created

$3 \quad$ Created

3 Created

3 Restored

Information on soils and water quality were then gathered as required in the habitat evaluation section of the New Hampshire Method. The U.S.G.S. Topographical Maps and the corresponding National Wetlands Inventory maps were obtained for each site.

Field visits took place next. The wetlands were located from the maps and from information in their files. At the field visits, wildlife and plants were identified using field guides. Photographs were taken and pertinent data noted. The potential wildlife habitat 
and ecological integrity 6 were then measured by recording the information requested on the data sheets from the New Hampshire Method.

The data sheets for both the wildlife habitat value and ecological integrity value were completed because both values are closely related to each other. In addition, the wildlife habitat data sheets required information called for in the ecological integrity section. The completed data sheets for each site can be found in Appendix A.

After all the primary data was collected, a value was calculated from the data sheets for each wetland. This value represents the wetland's potential wildlife habitat. The objective was then to evaluate the hypothesis.

6 The term ecological integrity, as used in this study, means the overall health and function of the wetland ecosystem. All the functions that a wetland performs contribute to the ecological integrity of the wetland (Ammann, 1986). 
Chapter Six

\section{SPECIFICATION OF DATA}




\section{Chapter Six}

\section{SPECIFICATION OF DATA}

\section{NEW HAMPSHIRE SITES}

\section{Portsmouth High School}

Created Wetland

\section{Purpose}

This site was created as mitigation for isolated wetlands destroyed for an athletic field expansion at Portsmouth High School, in the City of Portsmouth, New Hampshire (Map 1). The City of Portsmouth applied for a permit to fill 4.7 acres of wetlands for the athletic field project. I decided to focus on the largest of the artificial wetlands, the one southwest of the baseball field. This created wetland consisted of one acre of shallow marsh/wet meadow. It was created as compensation for a similar wetland that was destroyed (see site Maps 2 and 3).

\section{Description}

Construction of the created wetland began in July of 1989. Therefore, the wetland was approximately two growing seasons old at the time of the site visit on August 10, 1991. The site had revegetated well (see photos, page 44). According to a wetland regulatory specialist at the US COE, this wet meadow/shallow marsh wetland drains into an unnamed tributary of Sagamore Creek (Herke, personal communication: 7/92). There was a moderate interspersion 
of the two wetland classes visible. Marsh and emergent vegetation were apparent, as can be seen in the photos.

There were visible plantings on the earth berm located adjacent to the ball field. Being in such close proximity to a school, it was eviden: that the wetland had been used as an educational site because the periphery was trodden. Less than twenty-five percent of the soils on the site were hydric, according to the US Soil Conservation Service's (US SCS) Soil Survey for this county (see Map 4). The zoning of the site was found to be residential, with one house to a $1 / 2$ acre. I estimated five buildings to be within 500 feet of the wetland edge. No wildlife was observed using the site.

\section{Portsmouth High School - Control Site}

\section{Natural Wetland}

\section{Description}

This wetland site is slightly over $3 / 4$ of a mile away from the High School and is located just southwest of the intersection of Peverly Hill Road and Middle Road (Map 5). This site was chosen because it is described as a palustrine emergent wetland, like the created wetland described above. However, after visiting the site, it was apparent that some the site had succeeded to include some scrub shrub (see photos, page 48). It is slightly larger in size than the artificial wetland (1.25 acres), because none could be found exactly the same size within one mile of the High School.

More than fifty percent of the soils on the site are hydric, according to the US SCS's soil survey (Map 4). The zoning of the site is single family residential, with one house to 20,000 square feet, or 
$1 / 2$ acre zoning. No mowing, draining, filling, or any other type of disturbance could be detected. There seemed to be little or no human influence on the site. The site was, however, located adjacent to a fairly busy local roadway, thus causing a slight disturbance to wildlife in the nearby upland. There was free vegetated access for wildlife along the well vegetated corridor straight to Sagamore Creek. 
Eortsmouth High Schocl.

Site Location Map

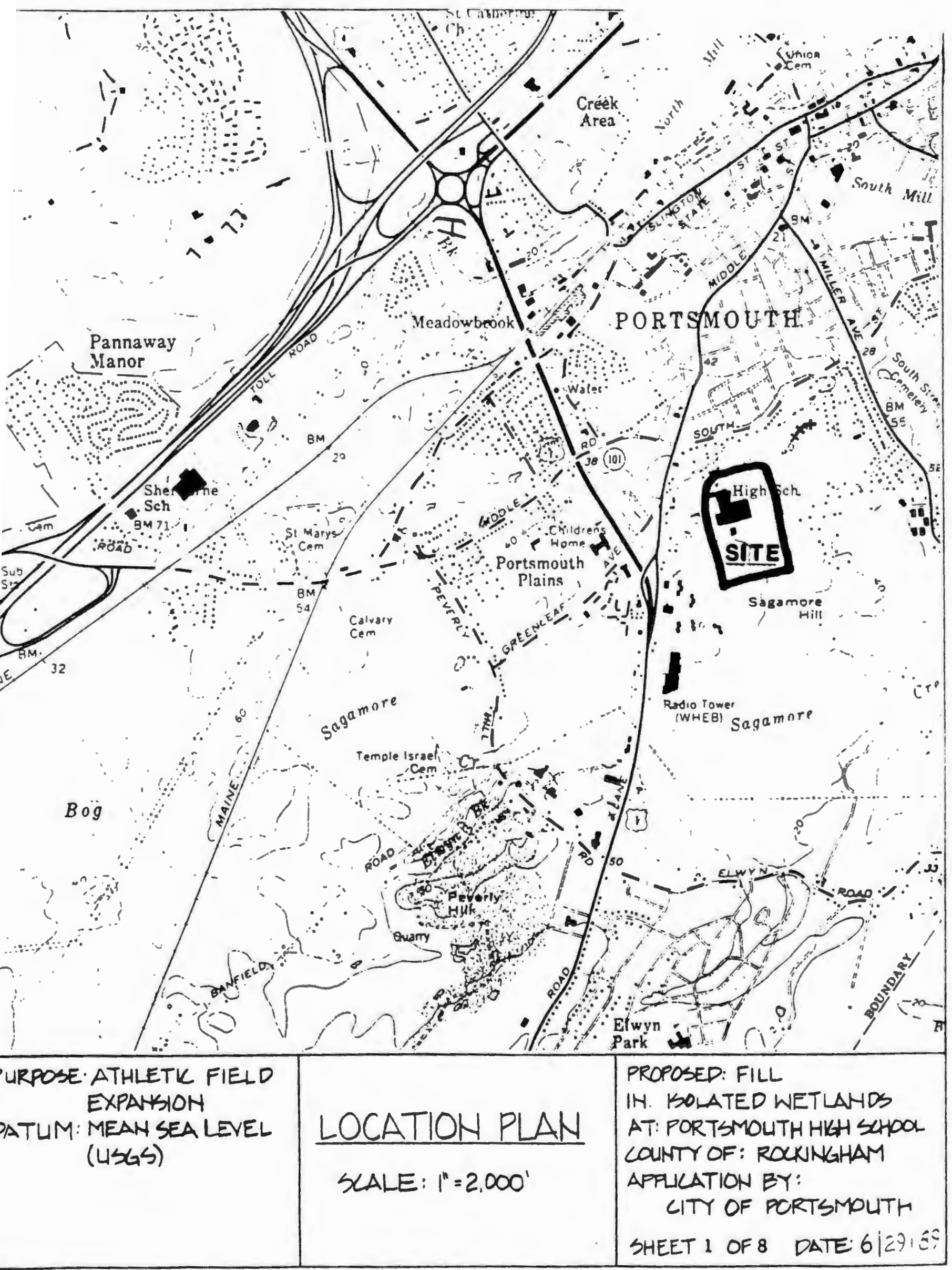


PORTSMOUTH HIGH SCHOOL

Created site
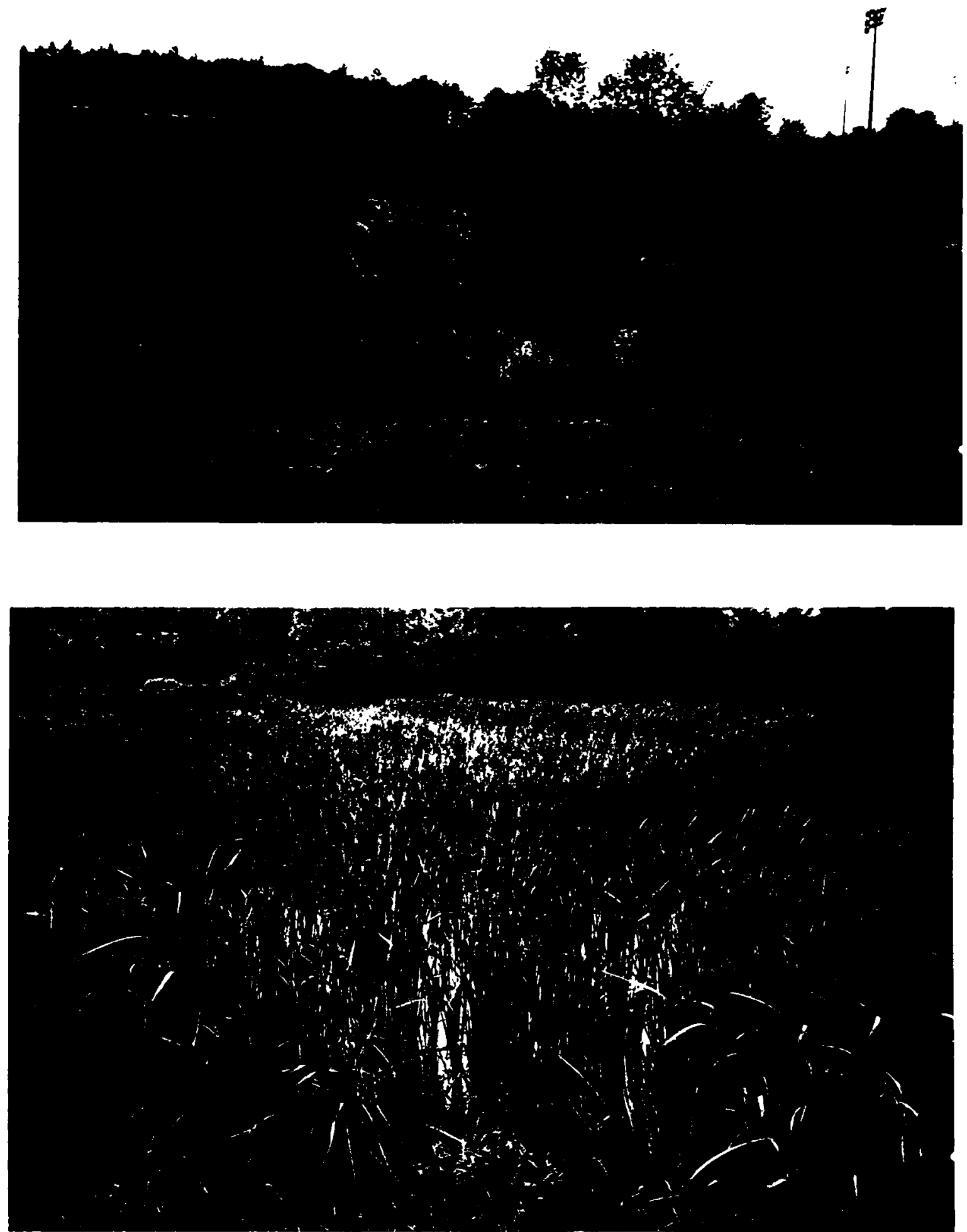


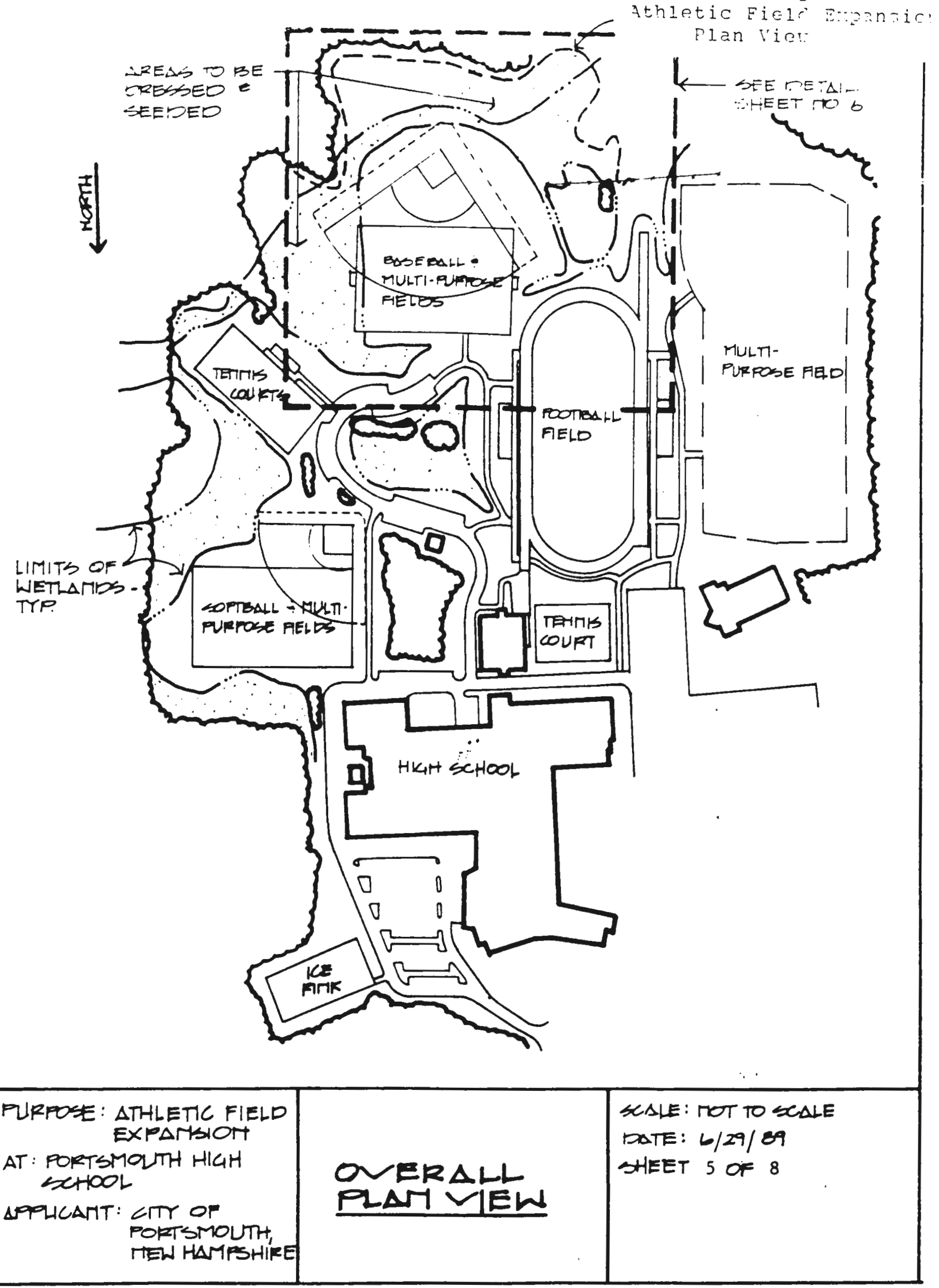


PORTSMOUTH HIGH SCHOOL

Control site
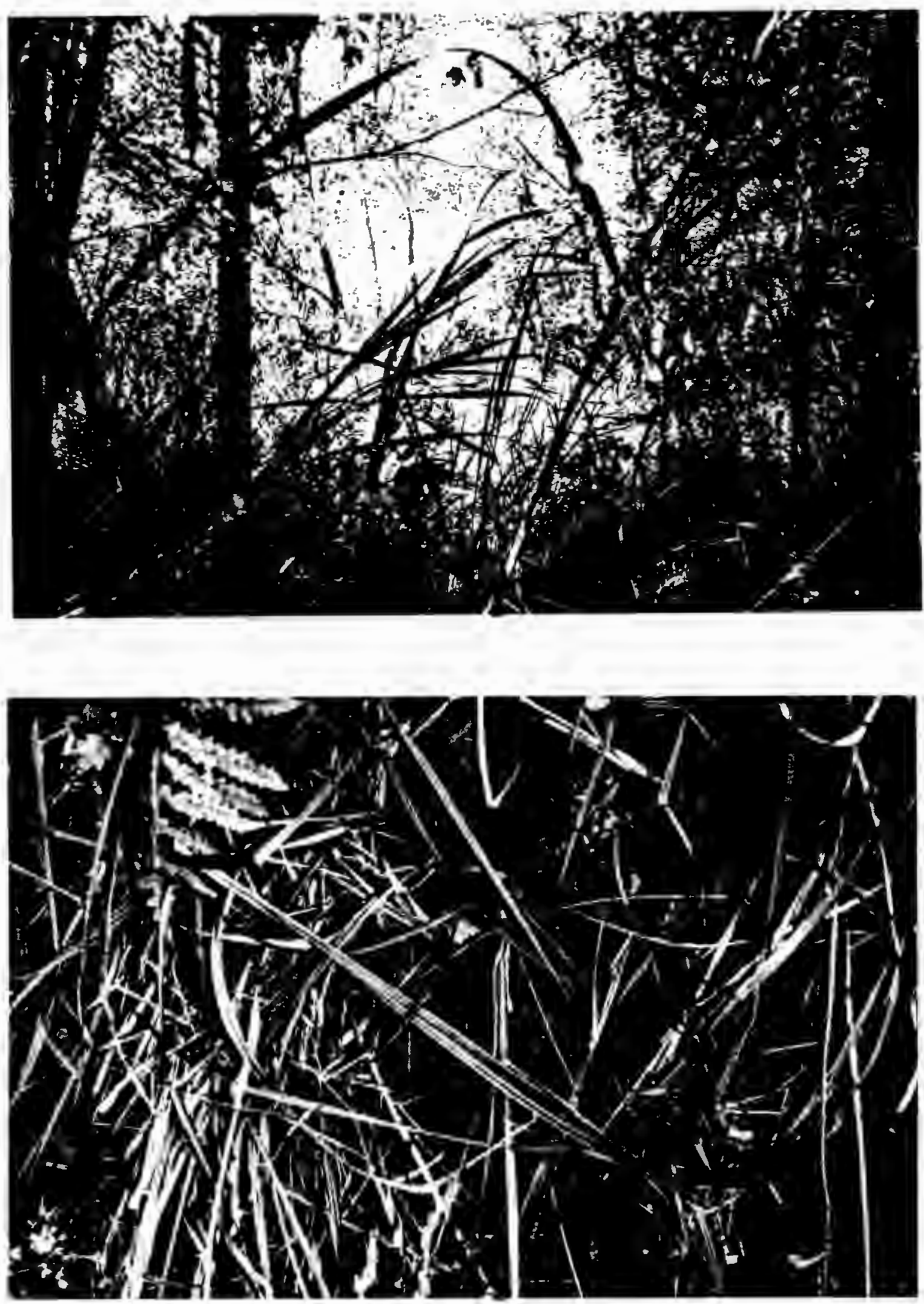


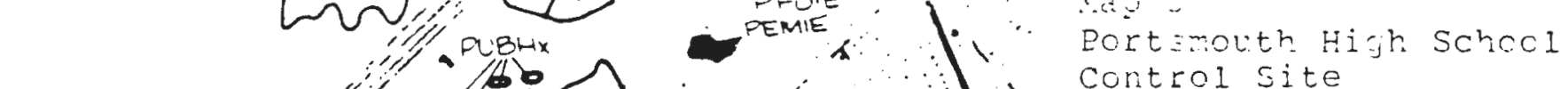
Control Site

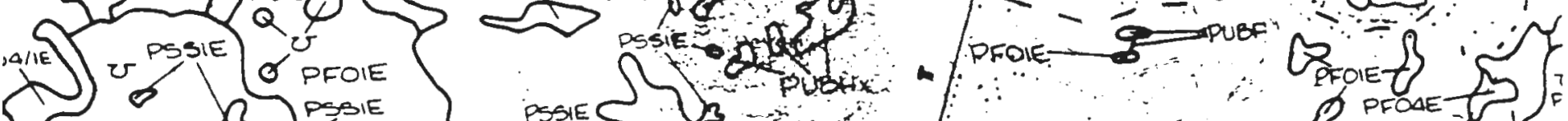

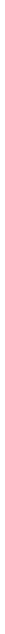

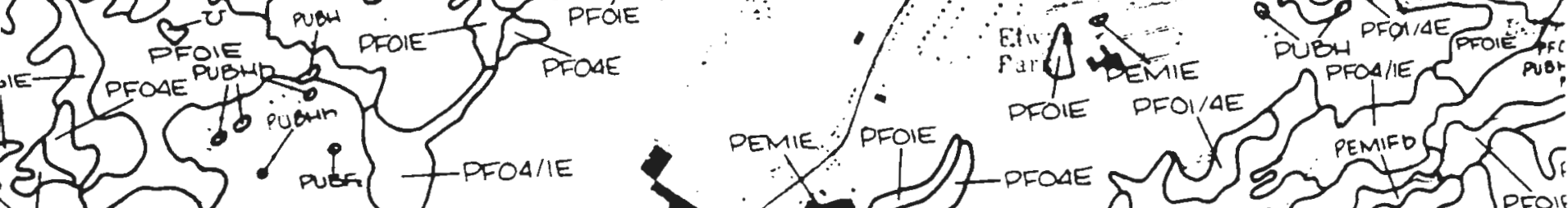
作

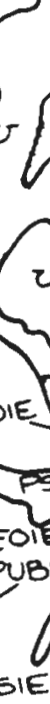

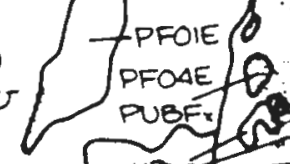
$\Omega_{\text {POOE }}$

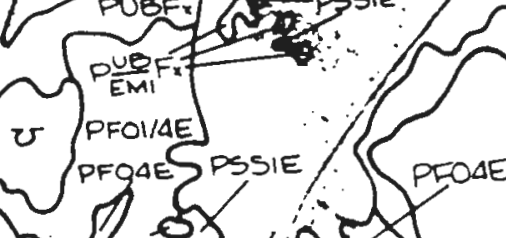
vits

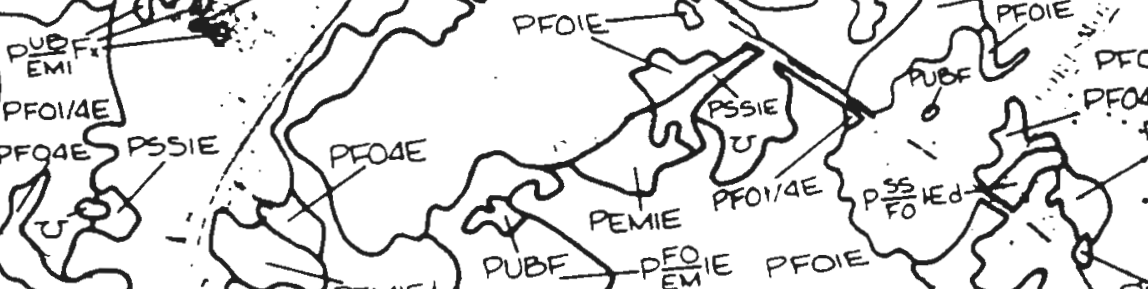
vuer, (6)

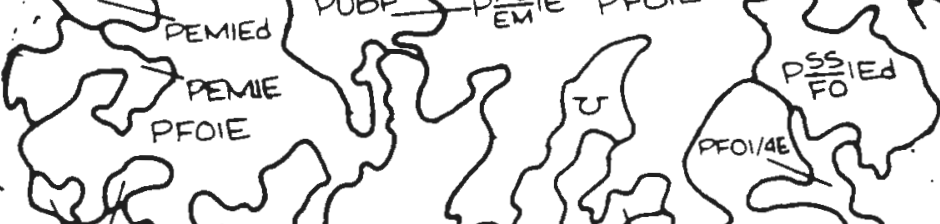

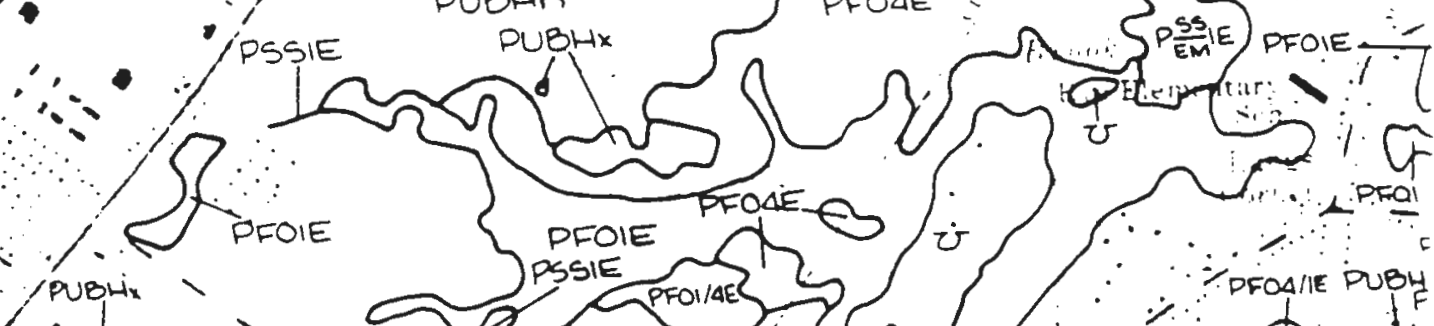




\section{Bradgate Associates}

\section{Created Wetland}

\section{Purpose}

Bradgate Associates Inc., developers, applied for a permit to fill $11 / 2$ acres of wetlands to create a residertial condominium complex called Meadowview Estates in Nashua, New Hampshire. The applicant later revised its plan to fill just less than one acre of wetland. Since the project involved the filling of less than an acre of wetland, the COE were granted a Nationwide Permit in April of 1986. Since the creation was permitted in 1986, it is estimated that the wetland was 4 growing seasons old at the time of the site visit on August 10, 1991. The creation was to include a .7 acre detention pond and surrounding wetlands, totalling approximately an acre of artificial wetlands.

Meadowview is located off Middle Dunstable Road in Nashua, New Hampshire (Map 6). The condominiums are attached units. The buildings are relatively close to each other, and appear to be in a "cluster" type of arrangement. The site work involved clearing the entire site, dredging and filling a 1 1/2 acre emergent wetland to create a detention pond and some upland for building foundations and parking lots (Map 8).

\section{Description}

The site visit showed the created area to be a relatively small pond in a large ditch (see site photos, page 53). The pond was smaller than .7 acres and most of the surrounding wetland area was being mowed. A small amount of emergent vegetation was seen around the periphery of the pond. 
There were about ten condominium buildings within 500 feet of the isolated wetland. The wetland was surrounded on all sides by either roads or parking lots. Thus, the site was not accessible to wildlife, other than those animals that could fly in.

It would seem that the residents of Meadow View used the wetland area for recreation because trash was seen in the ditch. The soils of the area were mostly hydric, according to the US SCS soil survey (Map 7).

\section{Bradgate Associates - Control Site}

\section{Natural Wetland}

\section{Description}

This site was visited on August 31, 1991. It is located just over a half mile north of the artificial site, along Salmon Brook (Map 6). Hydric soils were under most of the site, as was determined by the US SCS soil survey for Hillsborough County (Map 7). The wetland was an emergent type, similar to the created site at Meadowview Estates. However, there was a small amount of shrub vegetation (see photos, page 56). The zoning was quoted as $\mathrm{R}-18$, meaning one single family residence on a minimum lot size of 18,000 square feet. There were about six houses within 500 feet of the wetland.

A bridge crossed over the River, just adjacent to the wetland. Little human activity could be determined in the wetland itself. Wildlife could access the wetland from the well vegetated stream corridor. 

BRADGATE ASSOCIATES

Created Site
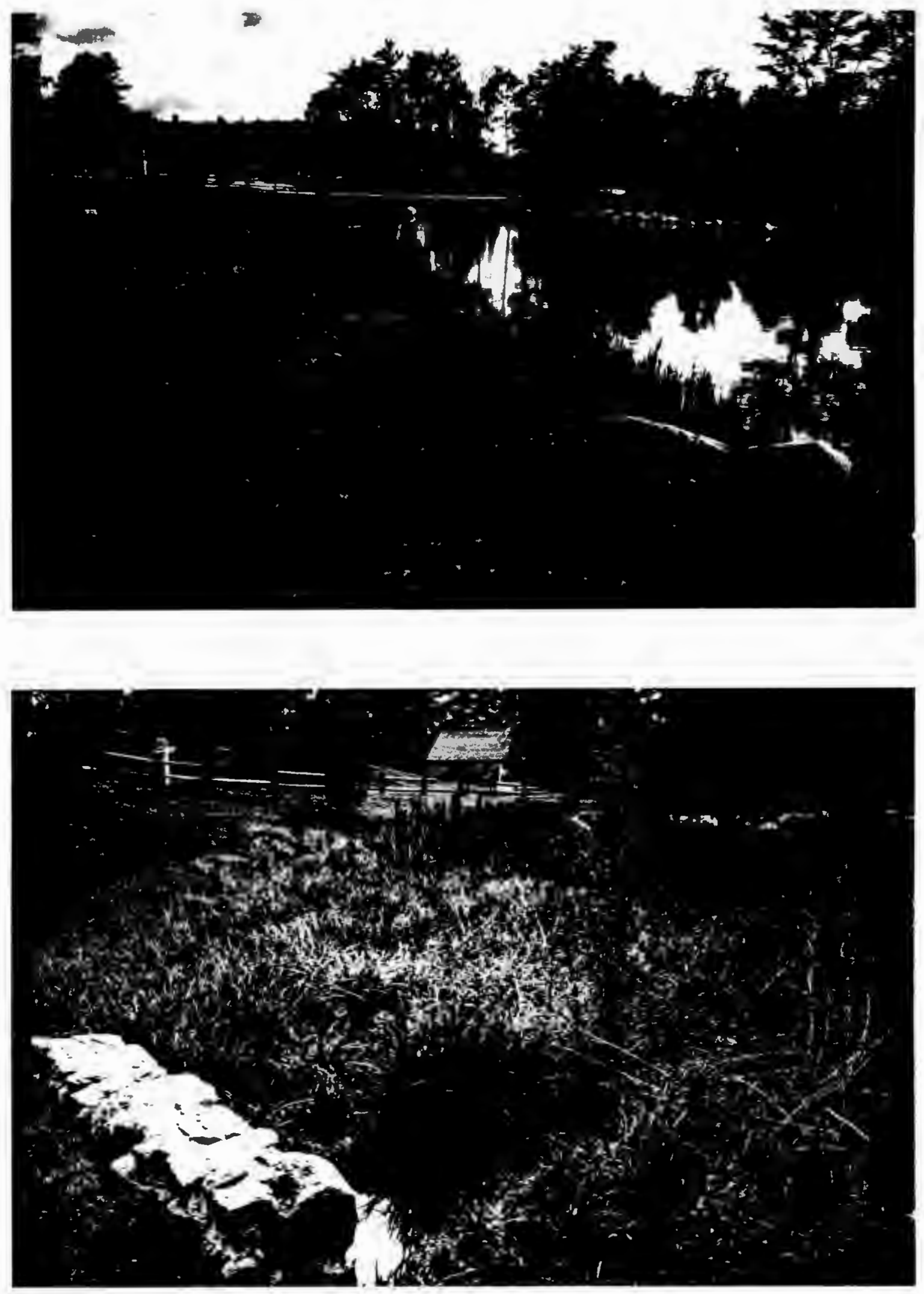



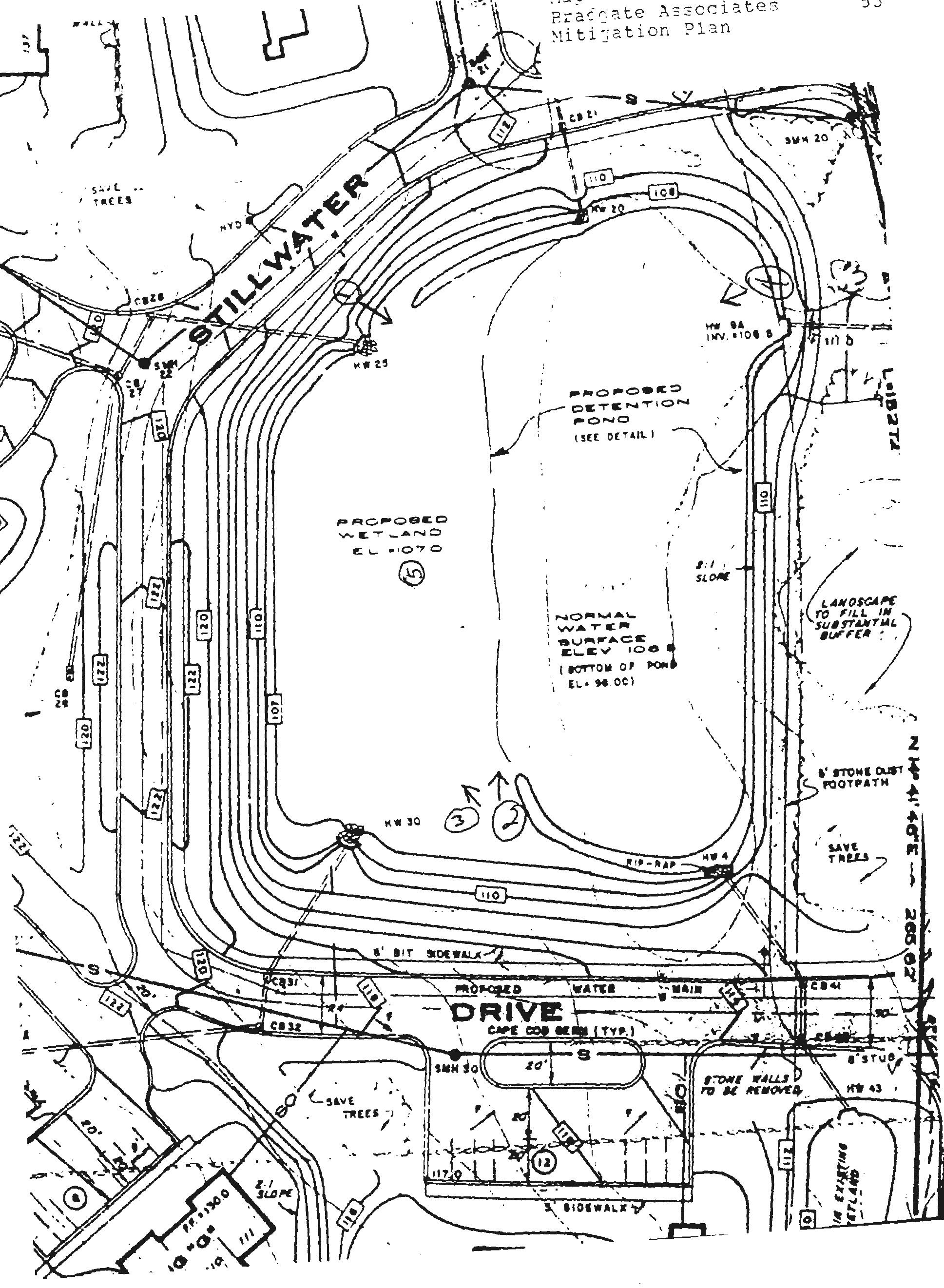


BRADGATE ASSOCIATES

Control Site
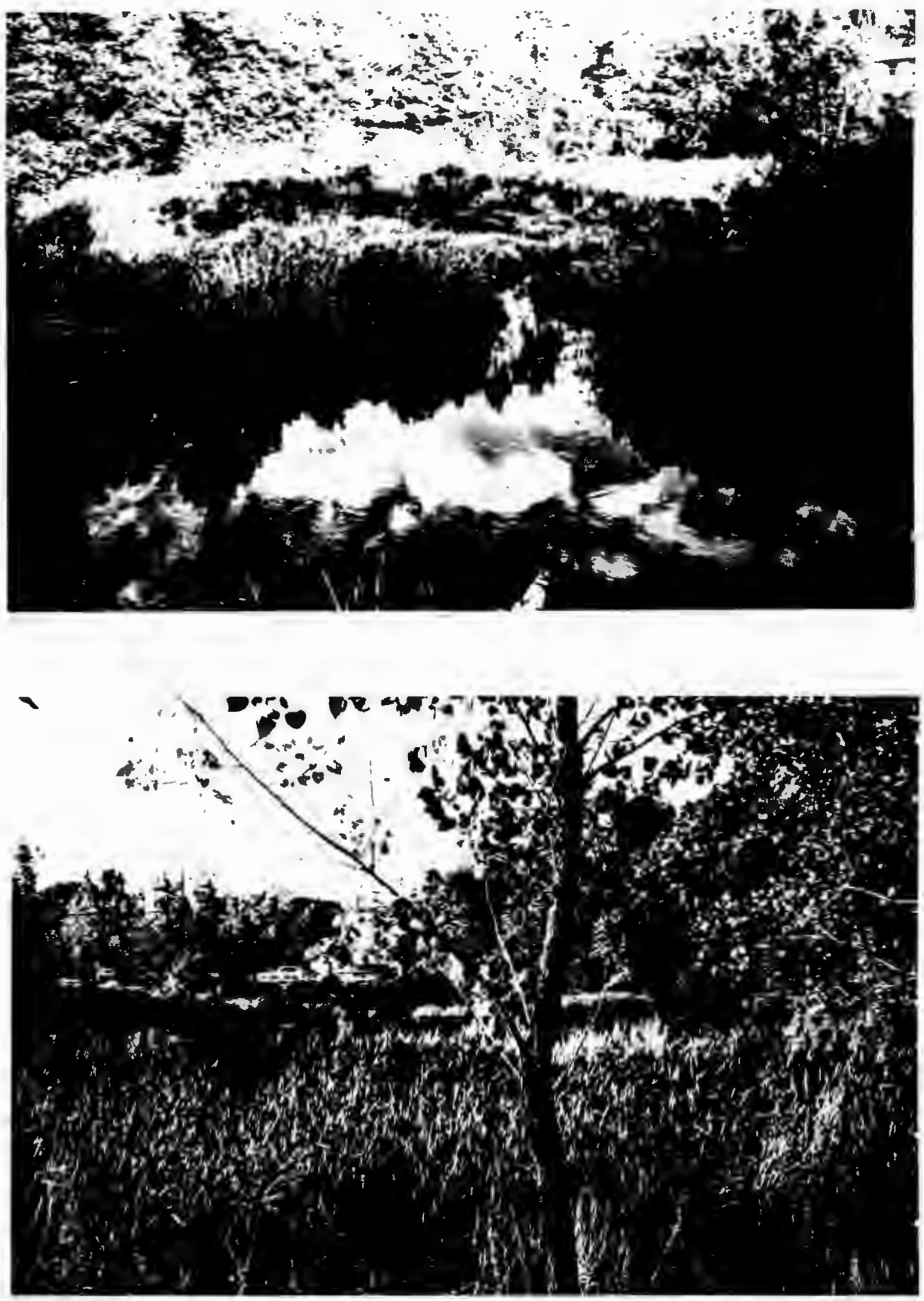


\section{Rockingham Mall}

\section{Created Wetland}

\section{Purpose}

The 4.5 acres of artificial wetlands on this site were created as mitigation for two wetlands that were filled to create the "Mall at Rockingham Park" and surrounding parking areas. The developers stated that the wetlands to be destroyed had low functional values because they had already been altered. They were granted a Nationwide Permit \#26 to fill 5 acres of wetlands. The wetlands were not only proposed as mitigation for those destroyed, but also for stormwater management.

\section{Description}

The mall was visited on August 31, 1991. At this time, the mall had just recently opened for business. The mall is located just west of Rockingham Park, a racetrack, in Salem, New Hampshire (see Map 9). The wetlands were created in three sites, totalling 4.5 acres, according to one of the members of the consulting firm that worked on the project, (Wood, personal communication: 8/28/91). I chose to focus on the two smaller of the three wetland sites. Together, the two sites totalled about one acre of artificial wetlands. They are located at the southeastern and southwestern corners of the property. The planting plans for these two wetlands can be seen on Maps $11 \mathrm{a}$ and $11 \mathrm{~b}$.

These wetlands were just under two growing seasons old at the time of my visit. They are considered a mixture of both emergent and scrub shrub vegetation (see photos, page 61). About 25 to 50 percent of the soil under the site is considered hydric, as discovered 
in the US SCS soil survey (Map 10). The zoning for the site is commercial/industrial, according to the planning department in Salem.

Seven buildings were counted within 500 feet of just one of the wetlands. Both wetlands were entirely fenced in. They appear to be small, deep, human-made ditches with wetland vegetation on the bottom. Thus, both sites were inaccessible to wildlife, except those that are able to fly. There was high activity in the upland surrounding both wetlands with the mall, its parking lots and ring road, as well as residences.

\section{Rockingham Mall - Control Site}

Natural Wetland

\section{Description}

The natural site was also located in Salem, less than two miles away, at the end of Veterans Memorial Parkway, adjacent to the Spicket River (see Map 9). This site was visited on August 31, 1991. The wetland was of the same types as the created wetland: emergent and scrub-shrub (Map 12). More than 50 percent of the soils were defined as hydric, according to the US SCS soil survey (Map 10). The zoning was quoted to be rural residential in this area. There were only two houses counted within 500 feet of this wetland.

Over 50 percent of this wetland was bordered by a woodland or natural buffer (see photos, page 66). There was ample access from the wetland to the vegetated stream corridor of the Spicket River, just adjacent to the wetland. Thus, the site was highly accessible to wildlife. No human activity could be detected within 
the wetland, and there was very little activity in the nearby upland as well. The wetland was located at the end of a dead end street. The street was only sparsely populated with homes. 
Re

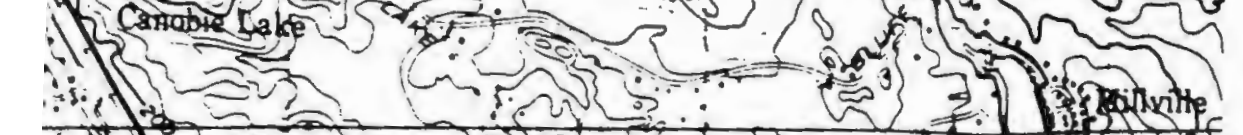
-

USGS Topo - Salem Depet Ola

?

(1)

(a)

J) $\{$ (

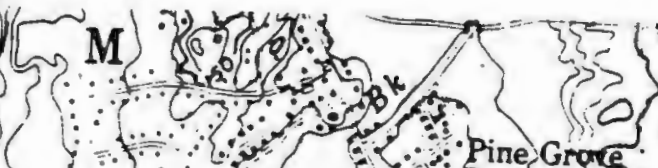

(1)

(1)

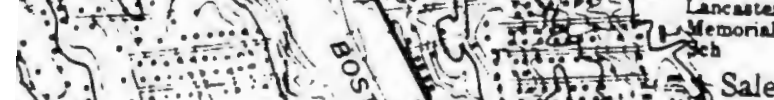

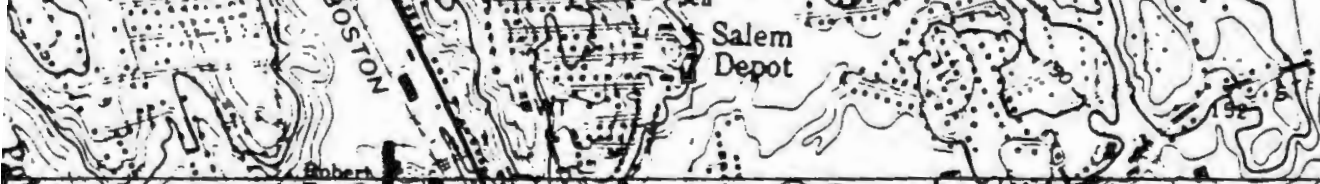

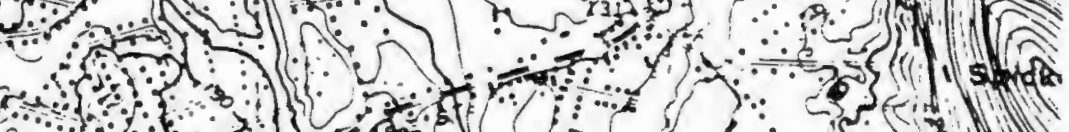
है

0.j,

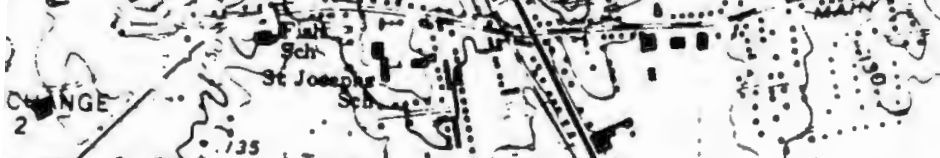

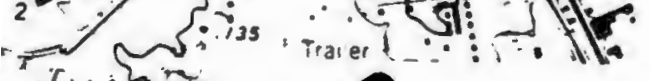
Rockingham Created site

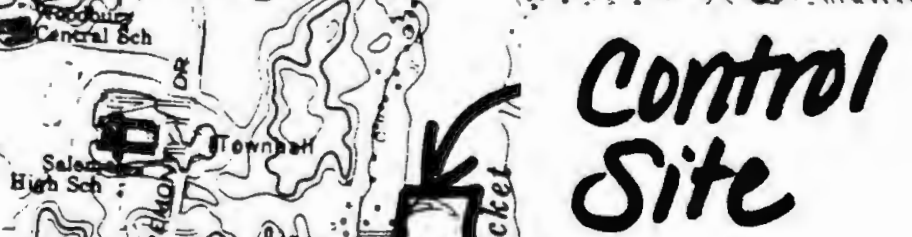
गु) $\therefore$ र 3 $\therefore$ $2 y^{3}$ (1) is

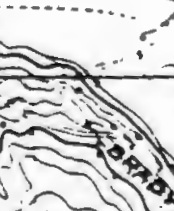
Northeastern

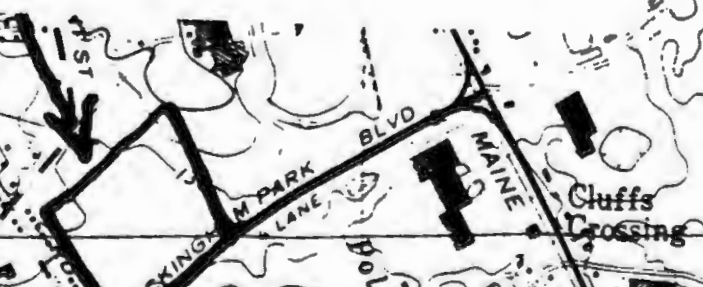

-Pर्ण aro 3 ? Interanto pi RCANGE

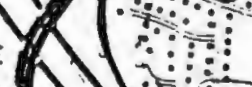

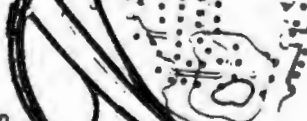

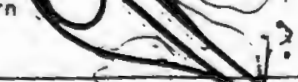

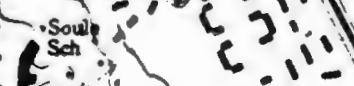

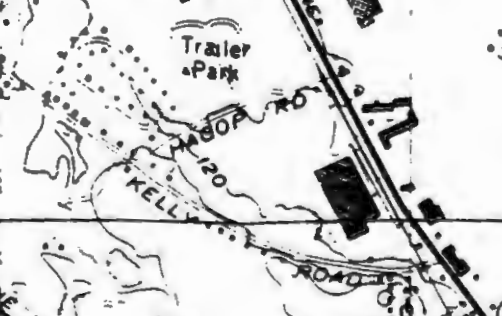

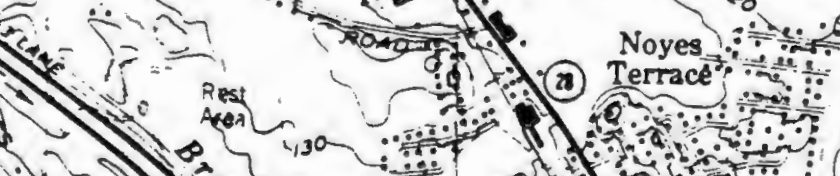
(a)
(20

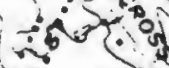

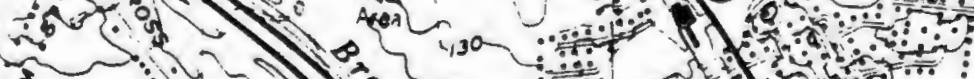

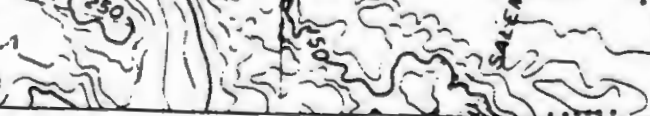

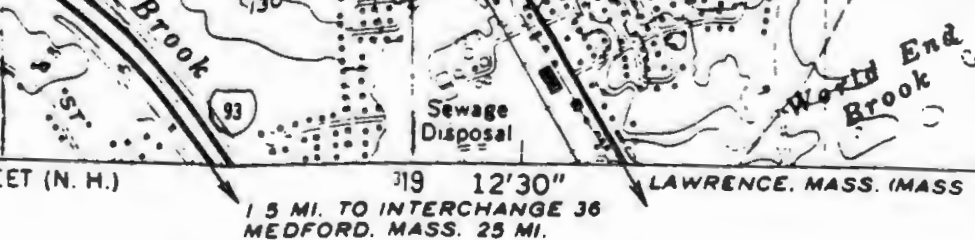

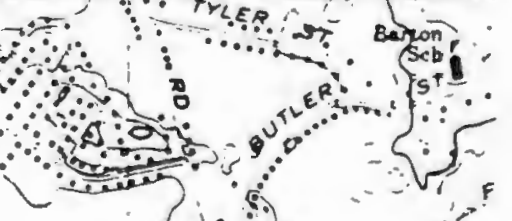


ROCKINGHAM MALL

Created Site
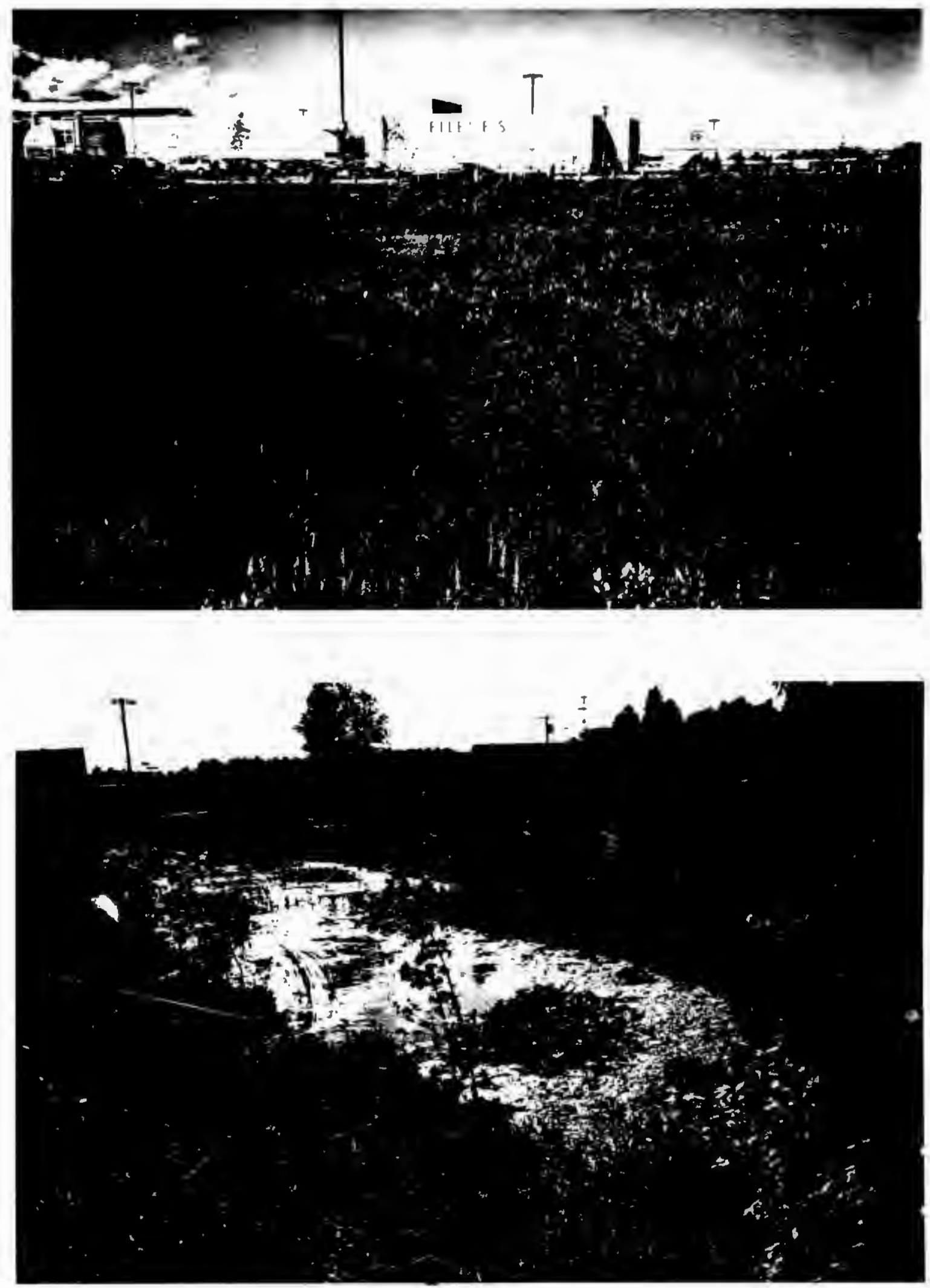
Rocking ham wail control site

Rockingham Mail 


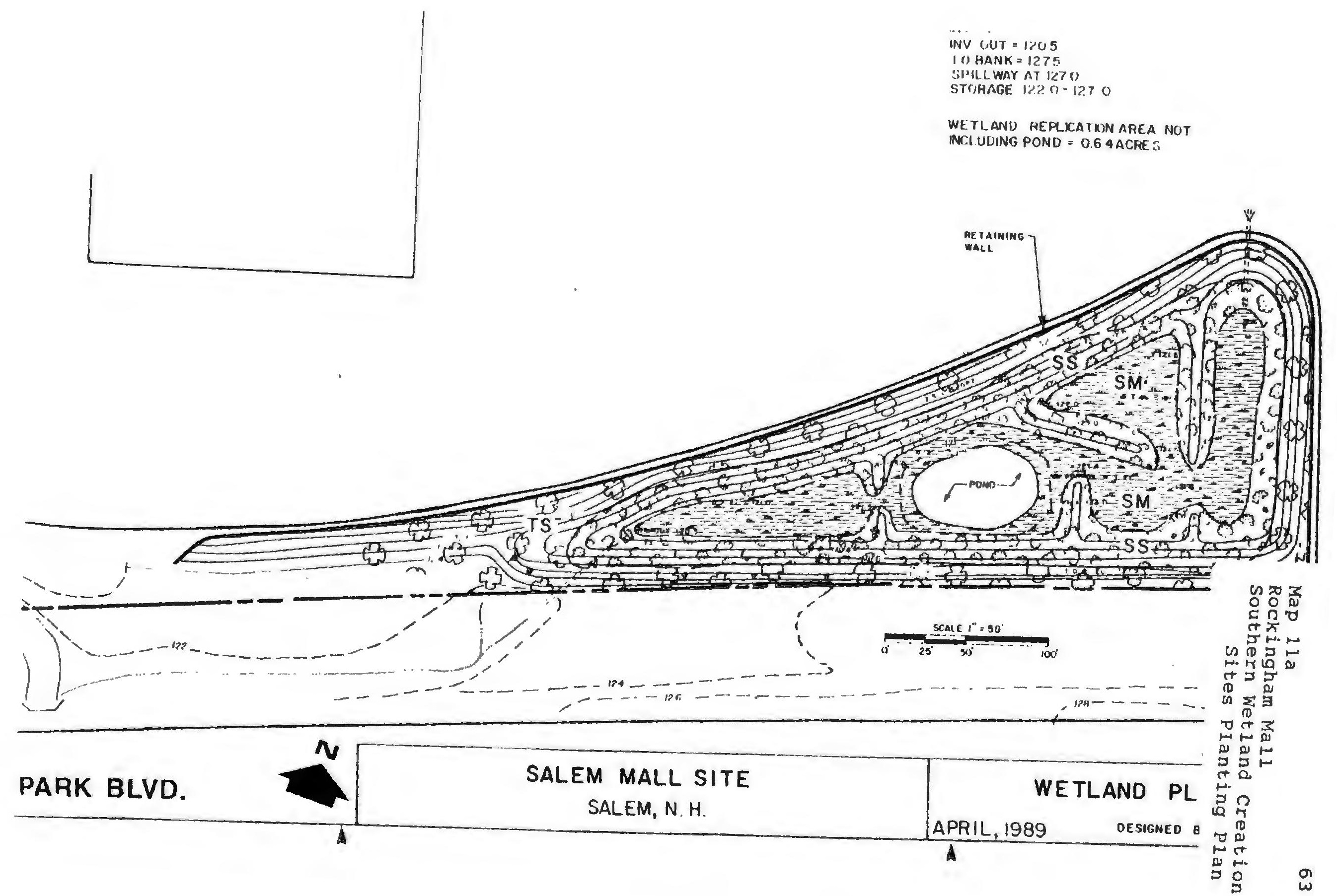




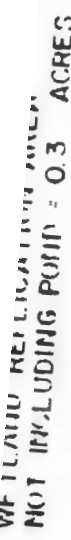

Maj 11'

Rockingham Mal1

Southern het land

sites Plartins Plan

$\frac{1}{5}$
$\frac{1}{0}$
$\frac{2}{y}$
0
0
0

$\bar{a}$

\section{sis}
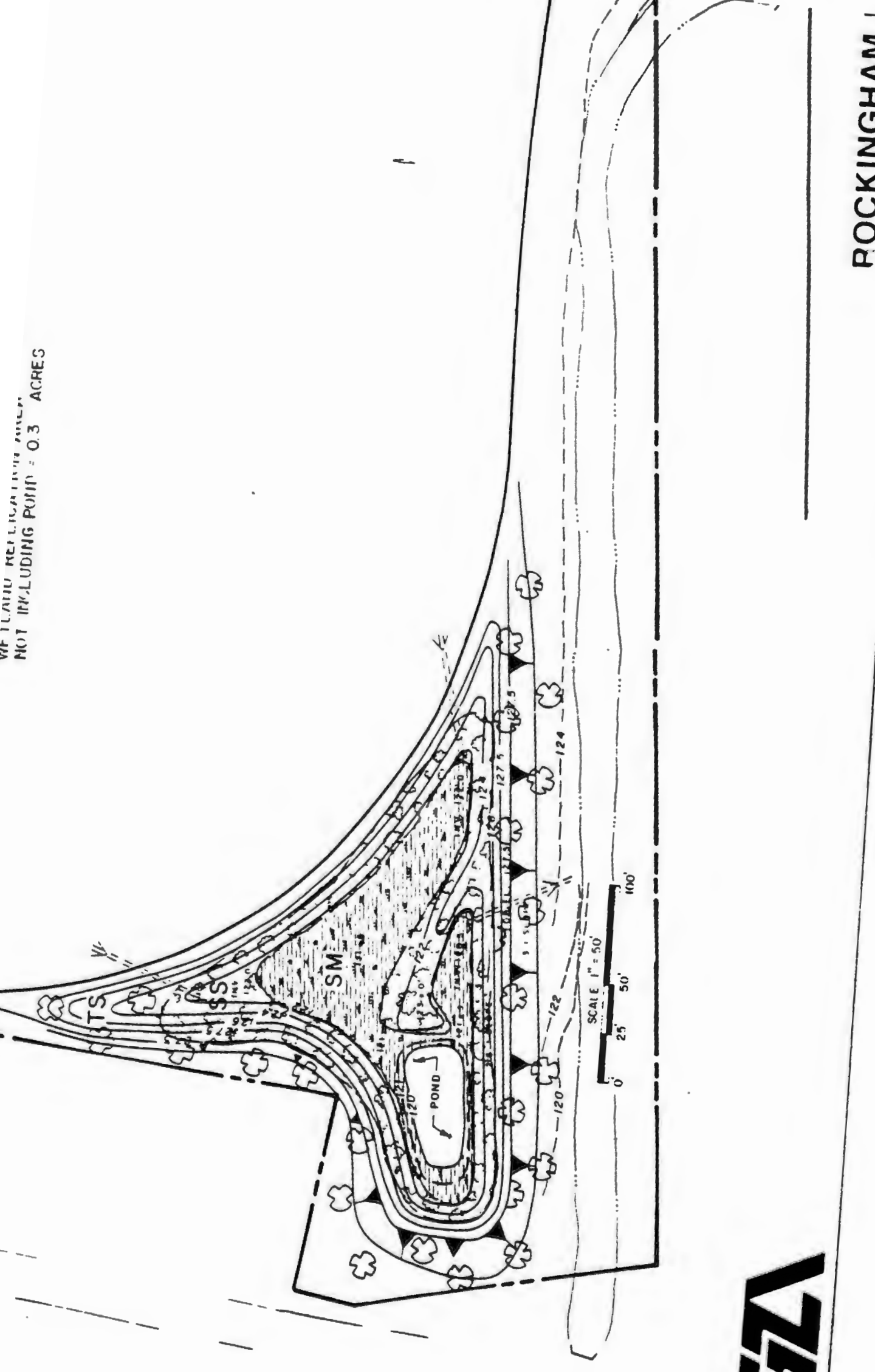

8 ONICZ.24380า00

2861

(2)

$86011-N$ ON 371$]$ 
ROCKINGHAM MALL

Control site
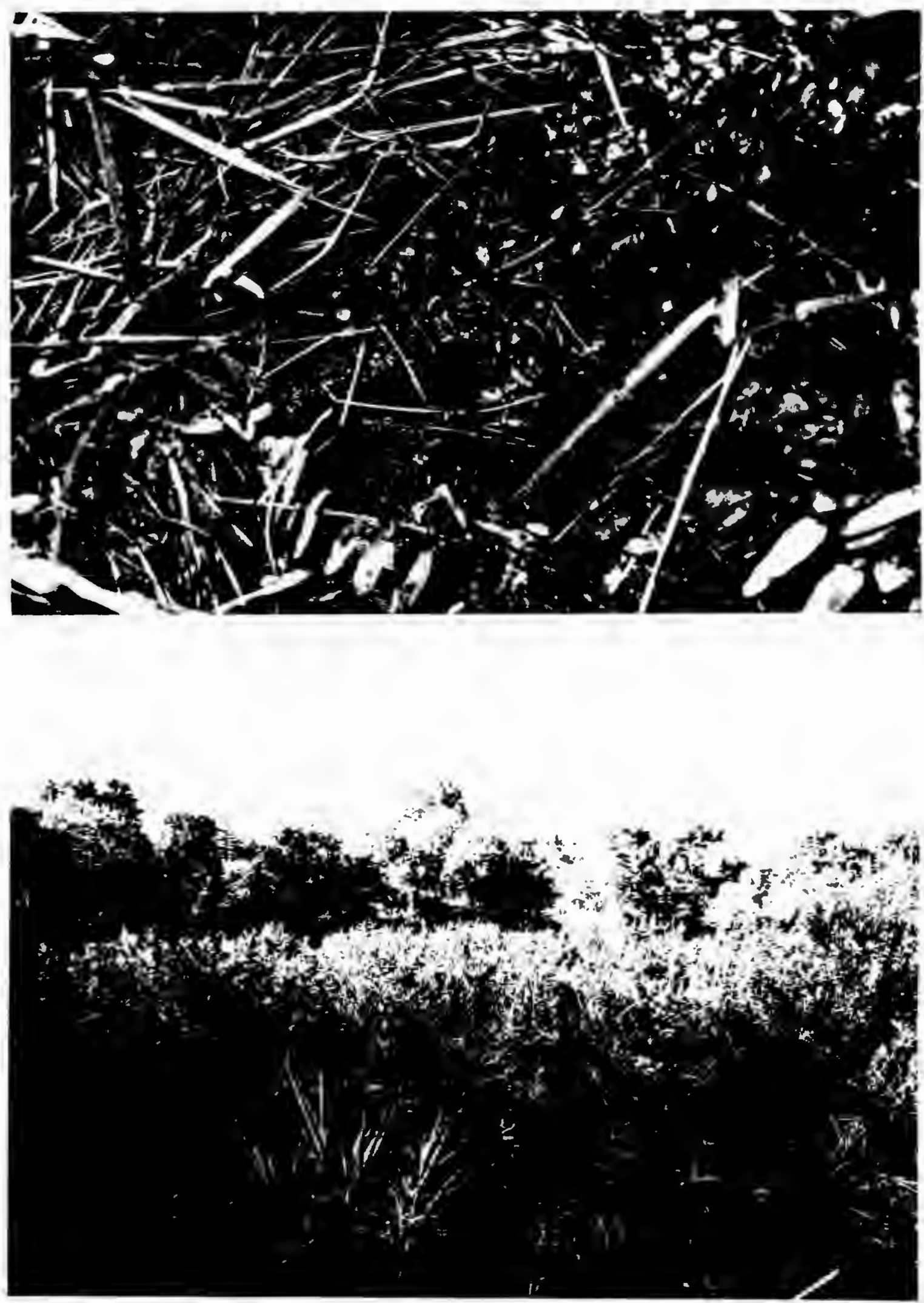


\section{RHODE ISLAND SITE}

\section{Woonsocket Industrial Highway (Route 99)}

\section{Created Wetland}

\section{Purpose}

In early 1987, construction of this highway began. Created wetlands were planned along with the construction to serve as mitigation for 6.7 acres of natural wetlands that were filled for the roadway. Approximately 6.7 acres of wetlands were created. Additional mitigation was in the form of wetlands enhancement and preservation.

The Rhode Island Department of Transportation (RI DOT), acquisitioned an eleven acre parcel which supports a 5.8 acre wetland. RI DOT will preserve this parcel. In addition, .1 acres of wetlands will be enhanced as partial mitigation for temporary fill in wetlands during construction of the Blackstone River Bridge. The existing wetland supports a dense stand of phragmites. Following the construction of the bridge and the removal of temporary fill, approximately .1 acres of wetlands will be excavated below existing grade to to promote the establishment of more valuable wetland plant species. Thus, mitigation for this project will include 6.7 acres of created wetlands, 5.8 acres of preserved wetlands, and .1 acres of enhanced wetlands. 


\section{Description}

The wetland areas were completed in 1988, and thus were about three growing seasons old when I visited them on August 24, 1991. The roadway runs approximately north to south from Route 122 to Route 146 in Lincoln, Rhode Island. The roadway and created site can be seen on Maps 13 and 14.

There were several artificial wetland sites; however, I chose to concentrate on "Site E," a 3.5 acre emergent/scrub shrub wetland, located just southwest of the intersection of the new Route 99 and Sayles Hill Road. This wetland is adjacent to the 5.8 acre wetland preservation area mentioned above (Map 15). The wetland was converted from an upland meadow and forested area to a mix of open water, emergent wetland, and shrub wetland (see photos, page $71)$.

From 25 to 50 percent of the wetland was listed as having hydric soils, as determined from the US SCS soil survey (Map 14). The zoning of the area, according to the Cumberland Planning Department is RA40. This zone allows one single family residence per acre. The wetland is associated with Crook Fall Brook. The Brook has a water quality of ' $B$ ' according to a water quality specialist at the US EPA - Region 1, (Hall, personal communication: 5/5/92).

One building was noted within 500 feet of the wetland edge. Since the wetland was surrounded by wooded/vegetated areas and adjacent to other contiguous wetlands, the site is easily accessible to wildlife. During my site visit, I could hear shots being fired in the adjacent wetland, indicating some people used the area for hunting recreation. 
Woonsocket Industrial Highway (Route 99) - Control Site Natural Site

\section{Description}

The natural wetland, visited on August 24, 1991, is located in the Town of Cumberland, Rhode Island (Map 16). This site is about three miles away from the created site. This site was one of the few exceptions to the two mile limit. No other similar sites could be located within two miles of the artificial wetland.

The site is estimated to have over 50 percent hydric soils, as determined thorough the US SCS soil survey (see Map 17). Since the zoning of the site could not be obtained (the only incidence of this in this study), the current land use was used, as allowed in the $\mathrm{New}$ Hampshire Method. The current land use was determined to be rural residential. There were about six houses within 500 feet of the wetland.

The wetland was located in a valley, surrounding a pond, (see photos, page 75). There was no evidence of human activity in the wetland, or even in the nearby upland. The wetland was surrounded by hills, forests, and fields, providing sufficient access to the wetland for wildlife. 


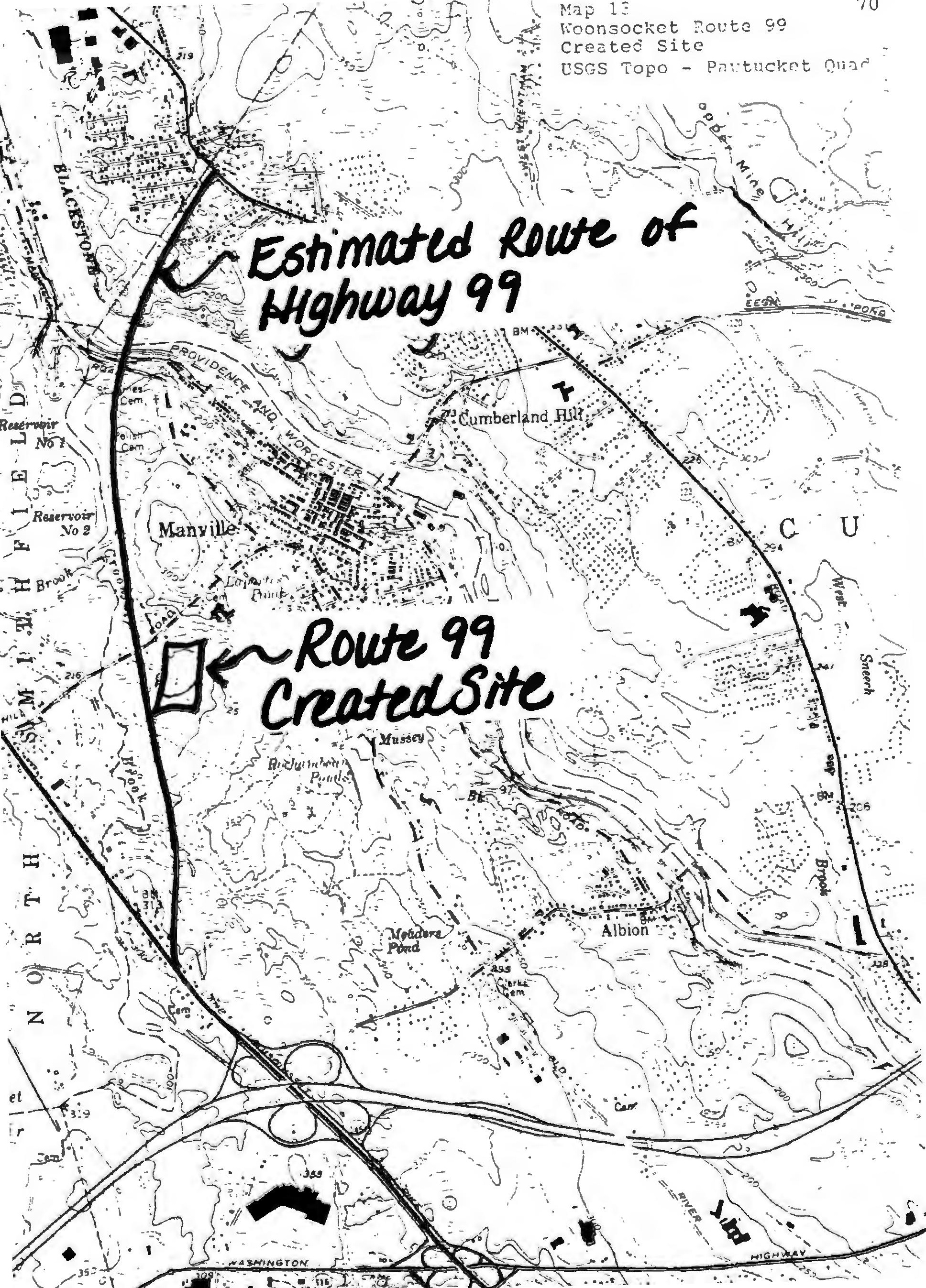


WOONSOCKET INDUSTRIAL HIGHWAY (Route 99)

Created Site "E"
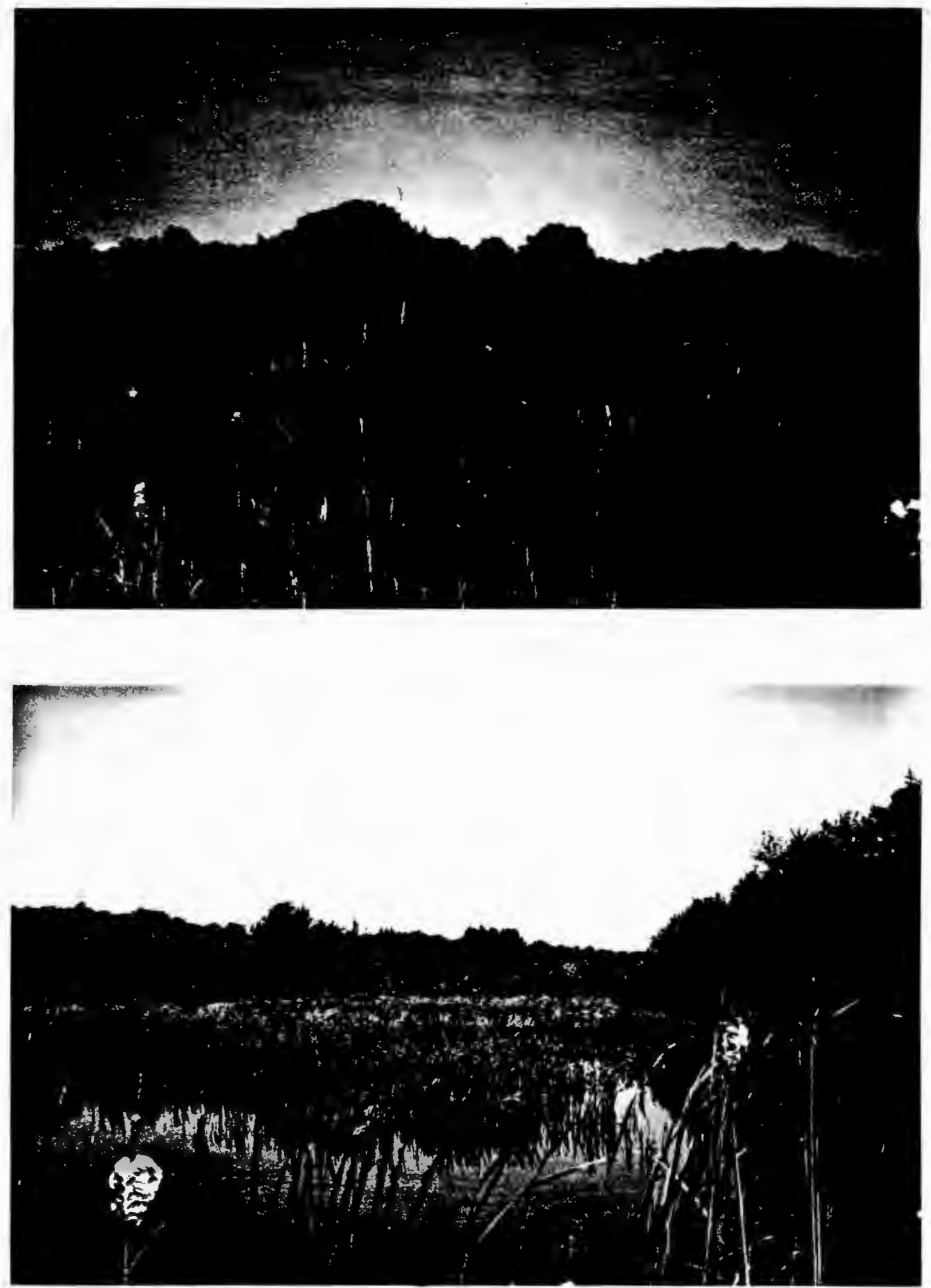


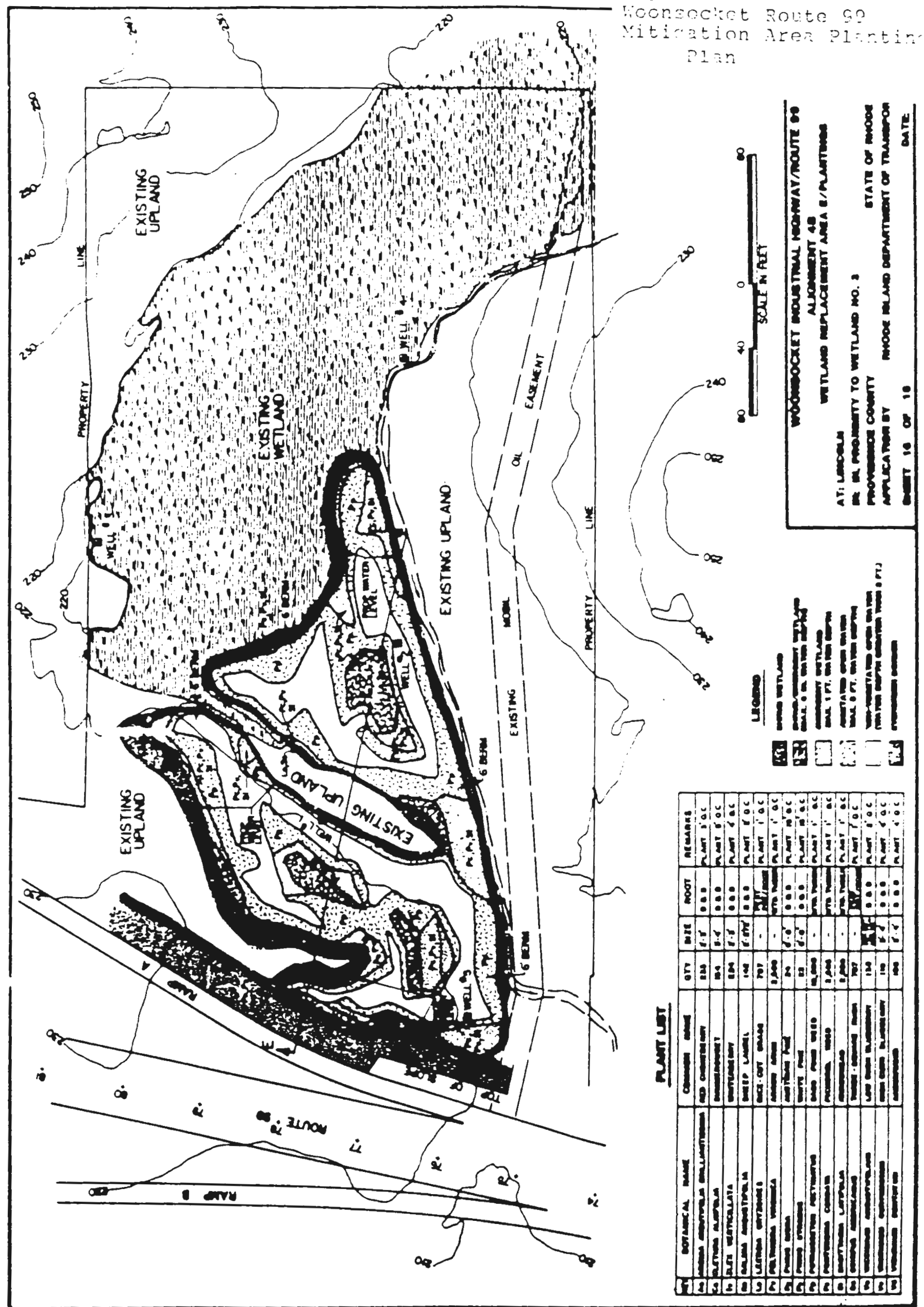


WOONSOCKET INDUSTRIAL HIGHWAY (Route 99)

Control site
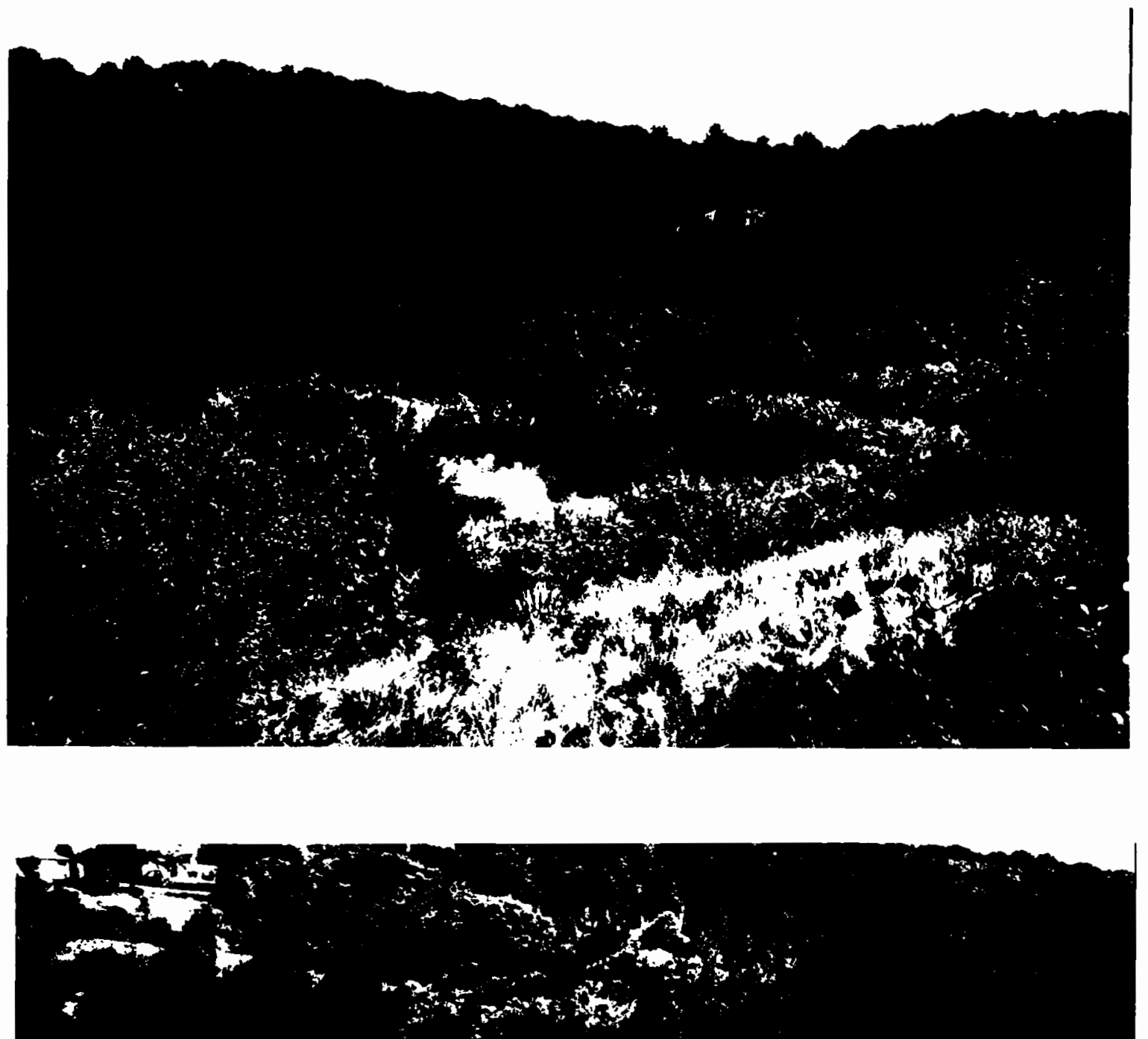


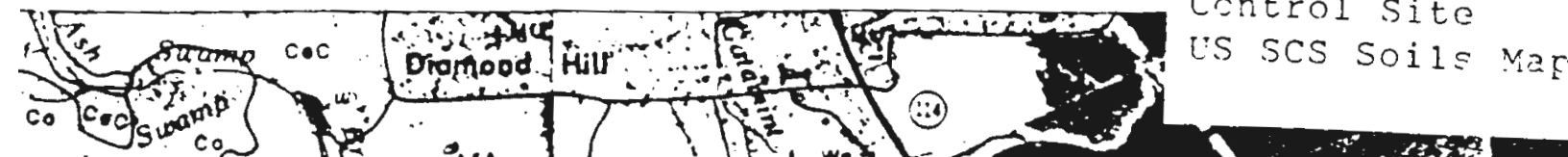

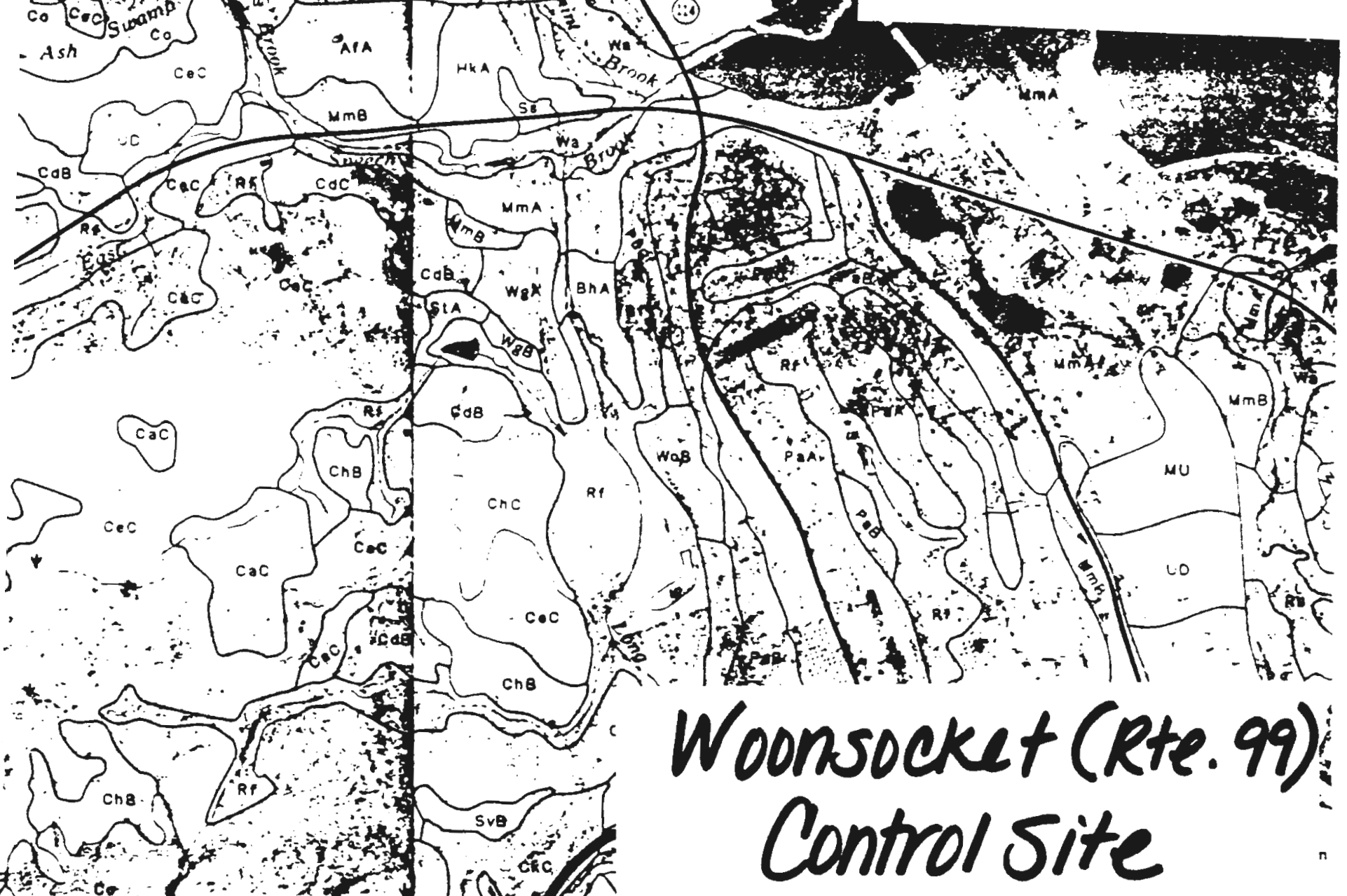

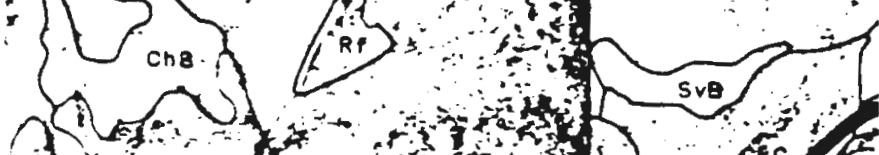

a

1 ra 0

M

8

B. E<smiles>C1CCCCC1</smiles>

\section{Woonsocket (Rte
Control Site}




\section{MAINE SITE}

Nemon

\section{Restored Site}

\section{Purpose}

An illegal filling of a wetland in Saco, Maine, was reported to the US EPA - Region 1, on June 1, 1987 (Map 18). This fill was in violation of Section 404 of the Clean Water Act of 1977. In addition to a fine, the violator was required to restore the wetland to its natural state. The violation occurred in two sites totalling 1.5 acres. I chose to focus on the .5 acre scrub shrub/emergent restoration on the property between Oakland and Hubbard Streets (see Map 19).

\section{Description}

The restoration was completed in 1989, and thus was three growing seasons old during my August 31, 1991 visit. The site appeared to simply be an open field with some wetland vegetation in it though parts of the wetland were wet (see photos, page 81). The site appeared to be an isolated wetland, not connected to any other water ways. Over 50 percent of the soils on the site were hydric, according to the US SCS soil survey (see Map 20). The zoning of the area was $\mathrm{R} 1 \mathrm{~A}$, according to the local zoning office. This means that one residence is allowed on a minimum lot size of one acre. There were five houses counted within 500 feet of the wetland edges.

There was some trash and a small amount of trodden vegetation in the wetland, providing evidence of some human activity within the wetland. The activity in the upland was moderate 
as well, with the wetland being surrounded on two sides with roads, and nearby residences. A small woodland was adjacent to the site, about 50 feet deep, however, there were houses on the opposite side of the woods. Thus, the only way wildlife could access the site would be by crossing a road or going throngh someone's yard.

\section{Nemon - Control Site}

\section{Natural Site}

\section{Description}

The natural site, visited on August 31, 1991, was located less than a half mile away from the Nemon site. The site is located west of the intersection of Route 112 and the Maine Toll Road, Route 95 (see Map 20).

Since no mixed emergent/scrub shrub wetlands could be located within two miles of the restored site, two separate natural sites were chosen; one emergent and one scrub shrub, almost adjacent to each other. The total combined area of the wetlands was .75 acres. The wetlands can be identified in the National Wetlands Inventory Map; Map number 21.

The zoning of this area is listed as commercial/industrial at the town level. These wetlands are associated with nearby Deep Brook. Only one house was counted within 500 feet of the edges of both wetlands. One side of both wetlands is bordered by a vegetative buffer that leads to the Brook (see photographs, page 84). This will provide wildlife access to the site. However, the opposite side of the wetlands has the major highway, Route 95 . The emergent wetland site is actually adjacent to the highway. Thus, even though there is 
no evidence of human activity within the wetlands, there is ample disturbance in the adjacent upland. 
$\therefore \therefore$ Brook

Map 18

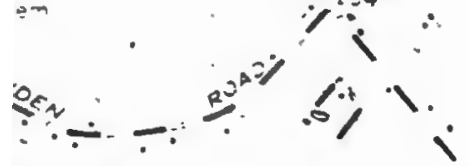

Nemon site

Restored and Control sites

USGS Topo - Old Orchard

Beach muad.

3ig Ledge

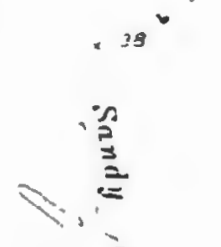

$\therefore$.

3
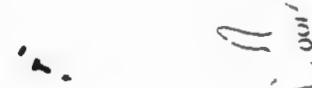

.39

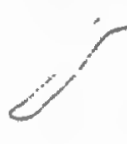

$\therefore$
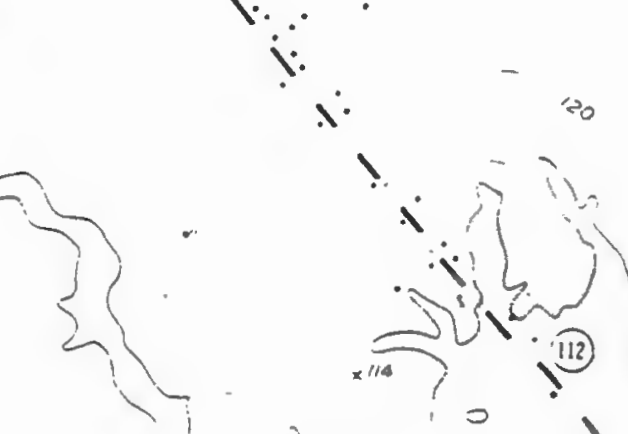

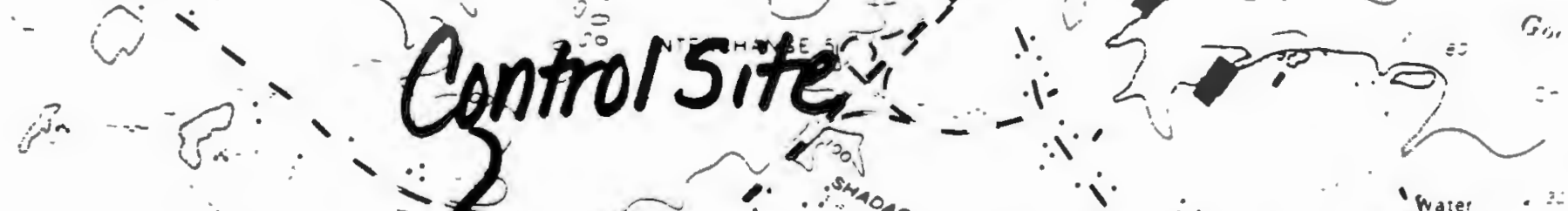

3

2
20
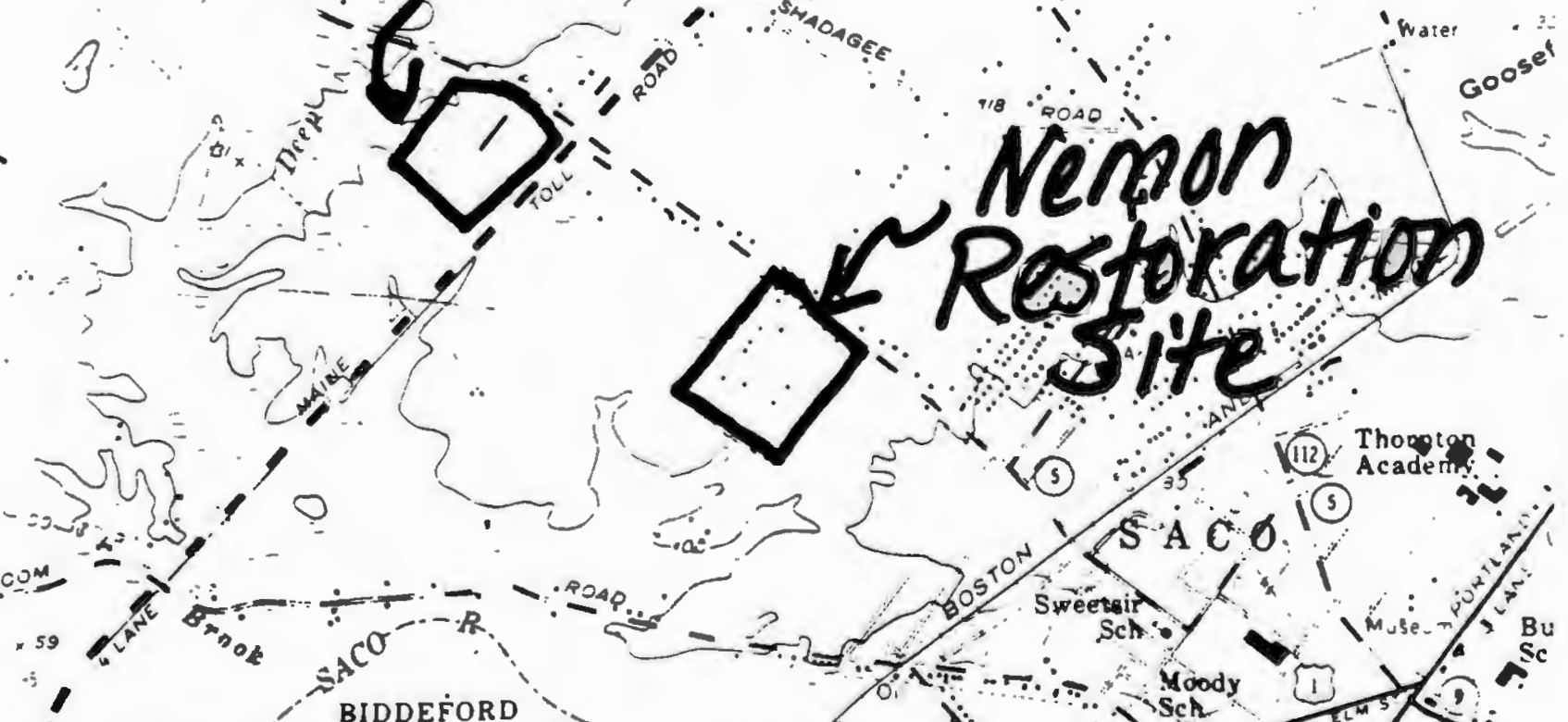

fism to interchinge.

BIDDEF́ORD

381

y the Army Map Service

of published by the Geological Survey

USGS and USC\&GS

d Jrainage in part compled from aerial photcgraphs

3. Topography ty oianetable surveys 1944

ised by the Geological Survey 1956

hy compiled from USC\&GS chart 231 (1954)

projection, 1927 North American dalum

it grid based on $M_{a}$ ine coordinate system.

r Universal Transuerse Mercator grid ticks, 
81

NEMON SITE

Restored Site
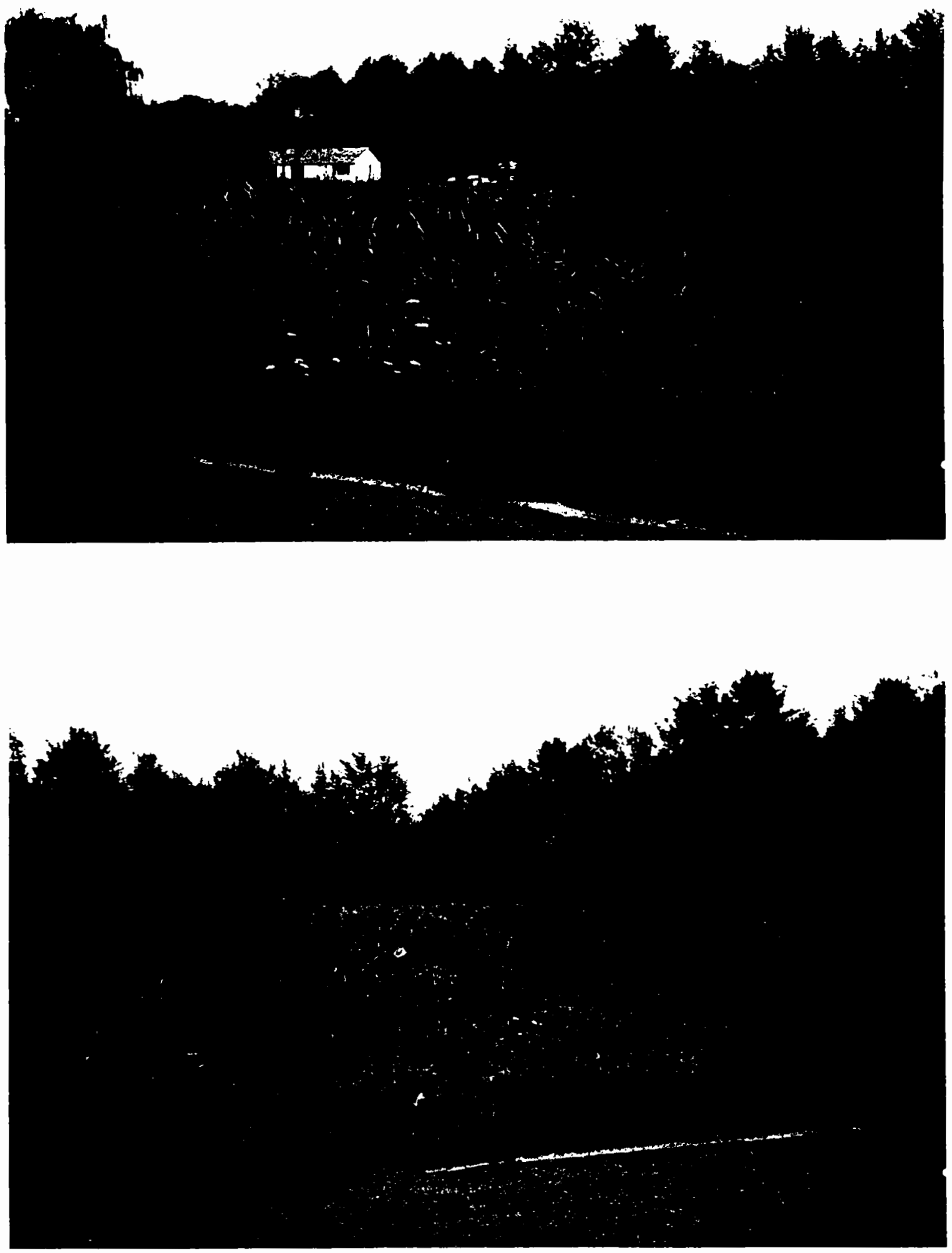


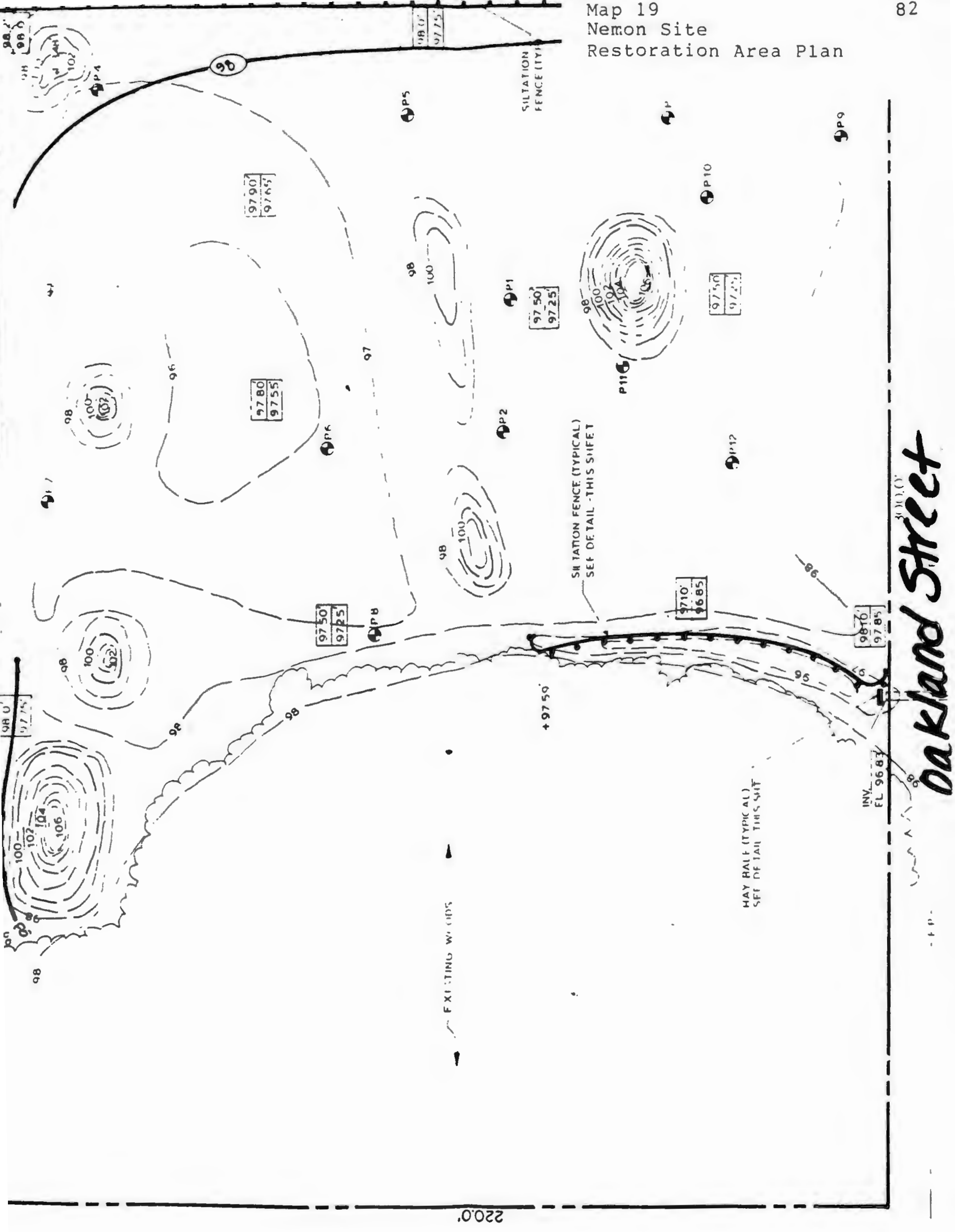



NEMON SITE

Control Site
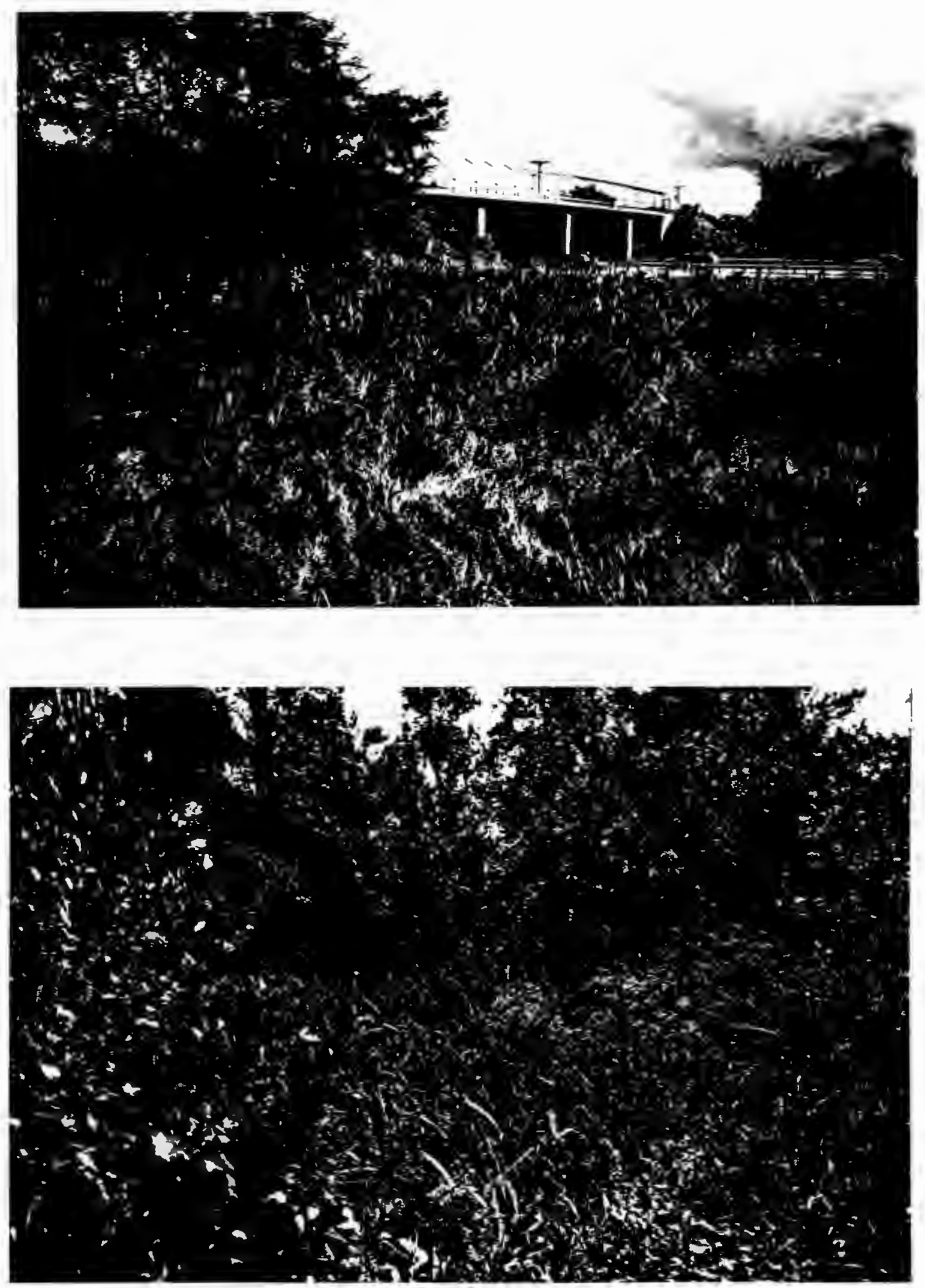



\section{MASSACHUSETTS SITE}

\section{Signal Resco/Resource Recovery Facility}

\section{Created Site}

\section{Purpose}

The construction of the Central Massachusetts Resource Recovery Facility, a trash to energy conversion plant, resulted in the disturbance of about a half acre of three separate wetland sites. One replacement wetland area will compensate for the three small disturbed wetlands. The replacement wetland is a .5 acre scrub shrub/emergent artificial wetland. The central and southern sections of the created wetland were converted from uplands. The northern section is a former wetland.

\section{Description}

The site is located on the border between the Town of Millbury and the City of Worcester, Massachusetts. It can be found next to Dorothy Pond, between Route 20 and the Massachusetts Turnpike (Route 90) on Map 22. The wetland is located in both communities, however, the majority of the wetland is located in Millbury, as can be seen in Map 25. The permit to alter the wetlands from the US COE was granted in 1985, thus the wetland was between five or six growing seasons old at the time of my site visit on September 28, 1991.

The compensatory wetland is long and narrow and is directly adjacent to the west side of the access road to the Recovery Facility (Map 24). Directly to the east and adjacent to the created wetland is an existing forested wetland (see photos, page 90). From 25 to 50 percent of the soils are hydric according to the latest mapping of the 
soils (Map 23). Since the majority of the wetland lies in Millbury, the zoning was obtained from that town. The site is in an 12 zone, or industrial zone, as reported by the Millbury Planning Department. Five industrial buildings were counted within 500 feet of the wetland edge.

The artificial wetland is associated with Broad Meadow Brook and other contiguous wetlands. About half of the wetland is bordered by a vegetative buffer of another wetland (on the eastern side of the wetland) which leads directly to the vegetative corridor of Broad meadow Brook. Thus, the site can be accessed by wildlife. There was no mowing of the wetland vegetation noticed, however, some purple loosestrife has worked its way into the created site.

There is no evidence of human activity within the wetland, however, there is significant disturbance in the nearby upland. Route 20 , the nearby local highway, is a heavily traveled road. The adjacent access road is well traveled by trucks hauling trash to the Recovery Facility to be incinerated. The huge Recovery Facility with its large smoke stack is also less than 500 feet away.

\section{Signal Resco/Resource Recovery Facility - Control Site} Natural Site

\section{Description}

The natural emergent/scrub shrub site was also located in Millbury, next to Shiner Hole Pond (see Map 26). The wetland is associated with an unnamed tributary of Ramshorn Brook. It is of similar types as the created wetland: scrub-shrub/emergent (see Map 26). This one acre site was visited on September 28, 1991. It is 
located in the middle of a large wooded, natural area, (see photos, page 95). It can be seen that the area is used for recreation because of the many well trodden trails throughout the woods. In the wetland itself, there was no evidence of human activity and a lot of deer sign was noted. Because of the ample wooded are? and nearby contiguous wetlands and pond, wildlife have sufficient access to the wetland.

The area is zoned as Suburban Residential, though there were no buildings in the area. The area was quite secluded and thus there was no evidence of mowing, draining, or any type of disturbance to the wetland. There were also no roads close-by. 
SIGNAL/RESCO RESOURCE RECOVERY PLANT Created site
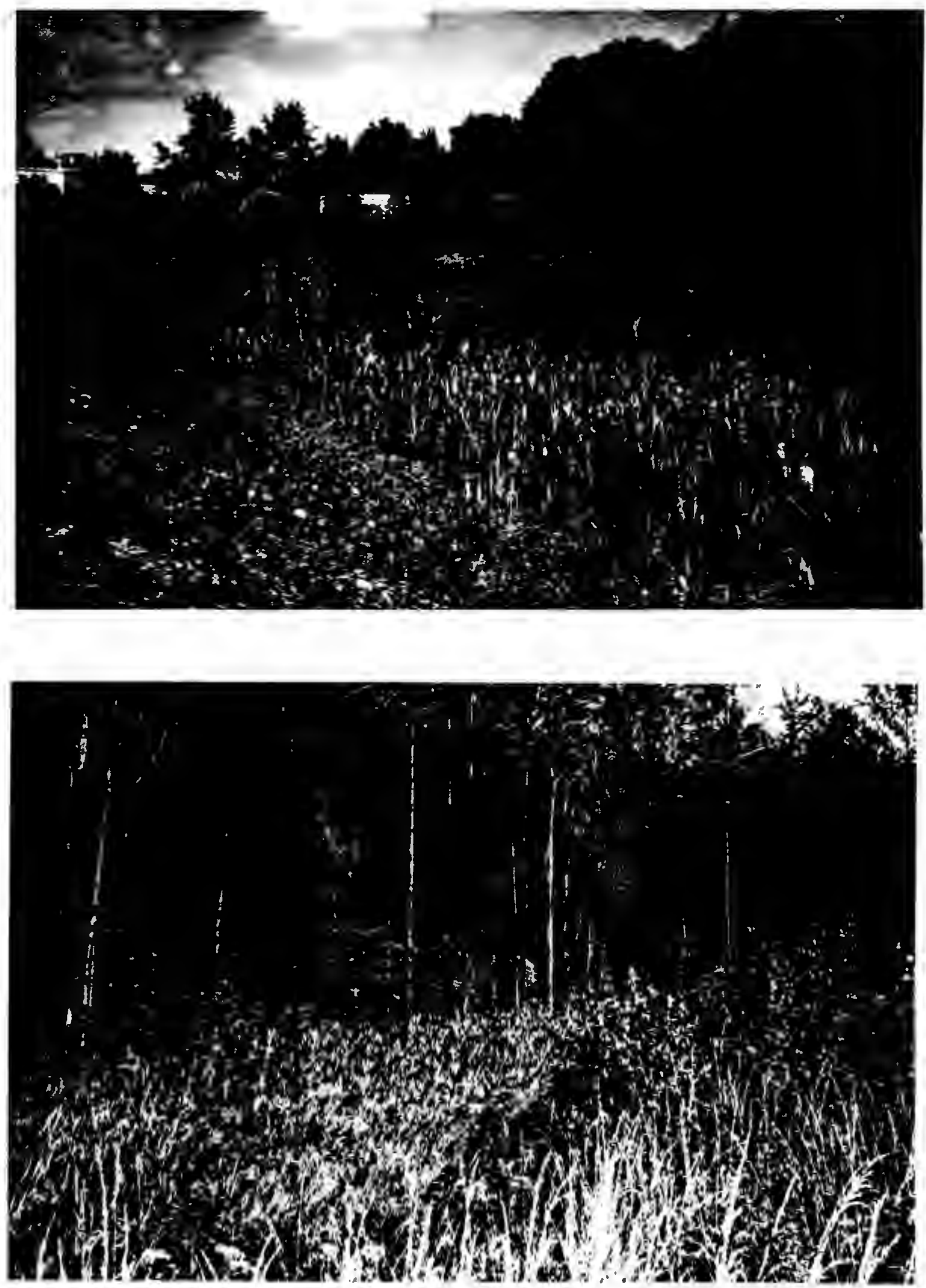


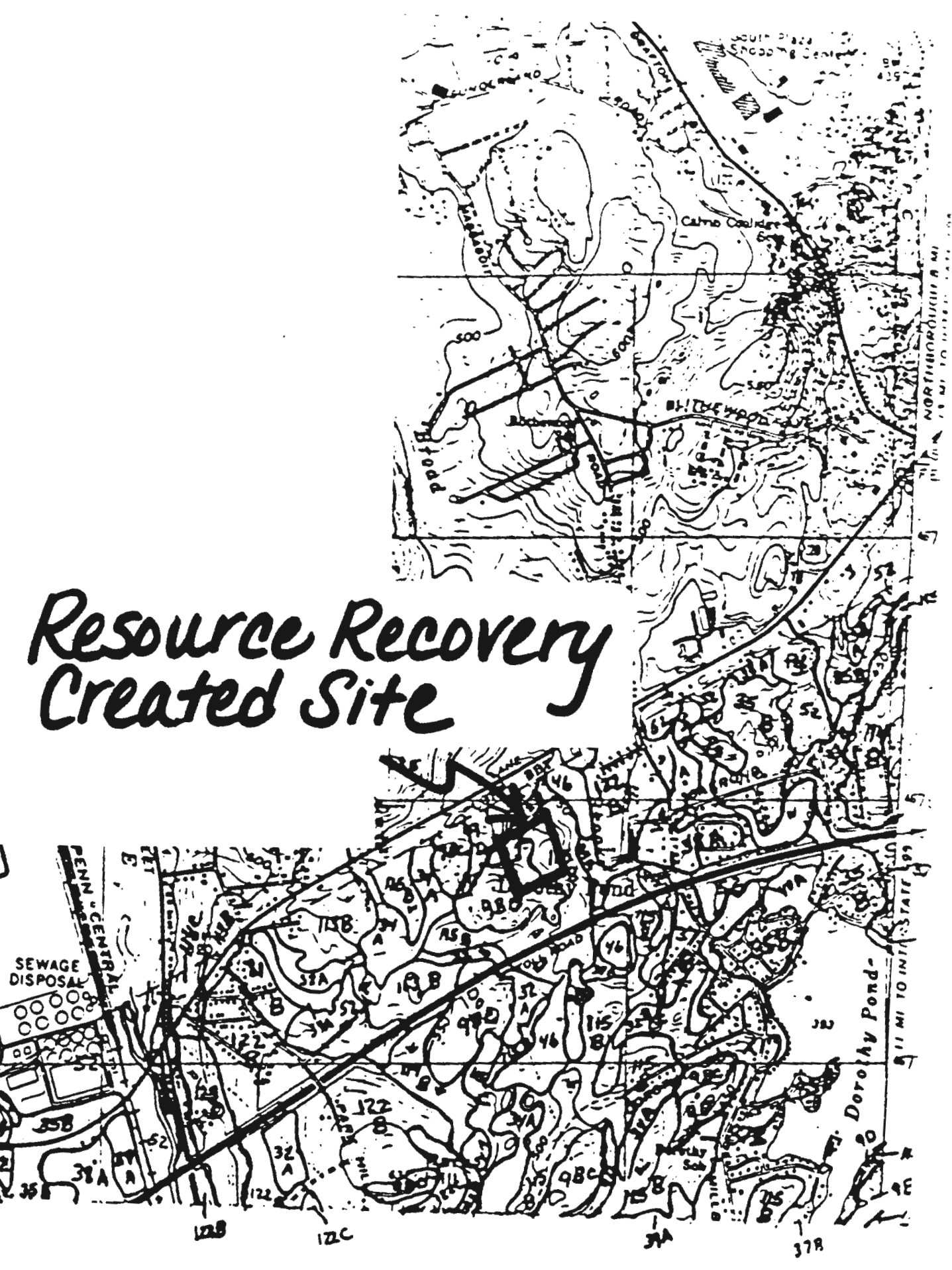

(1) 


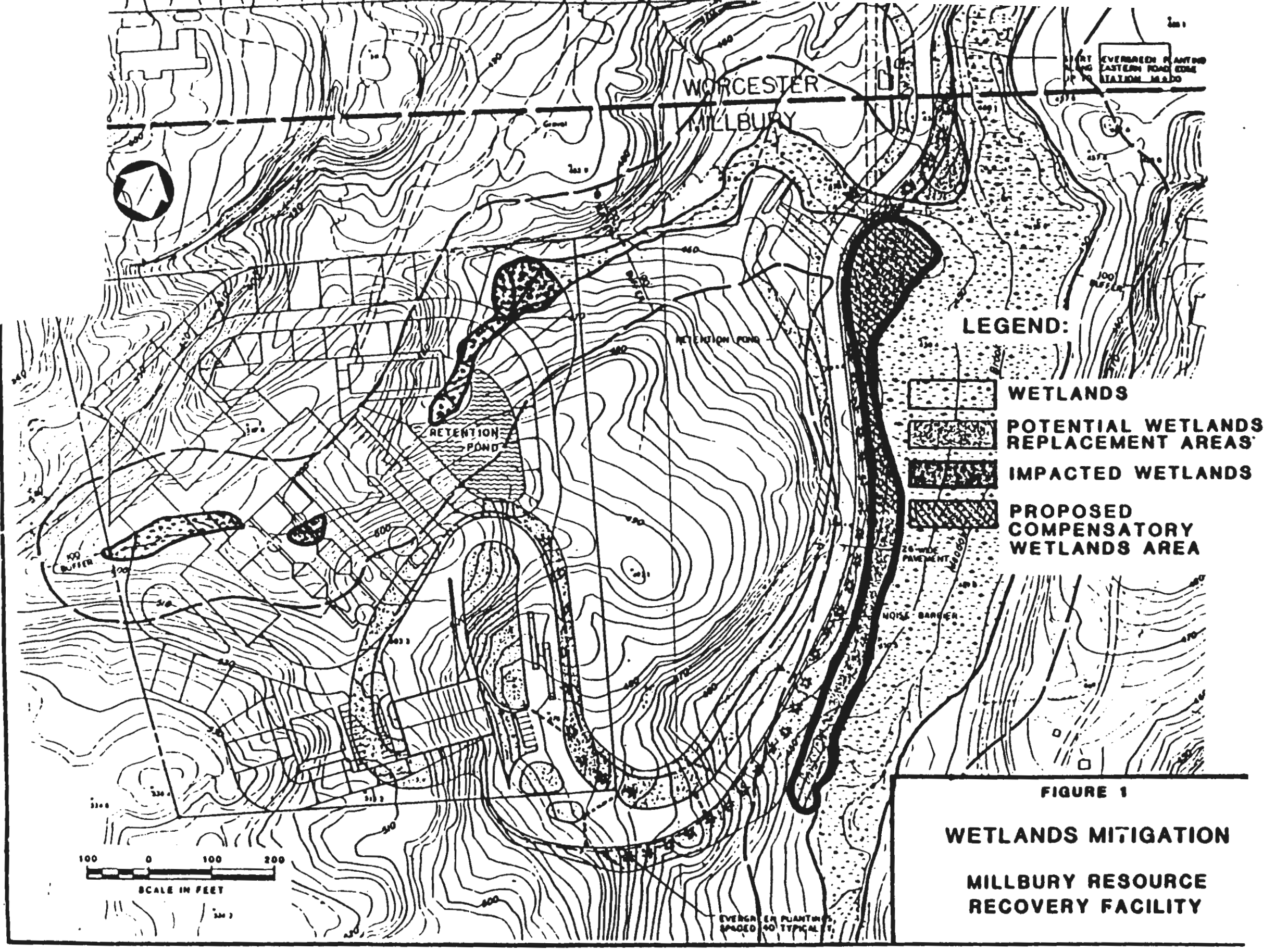



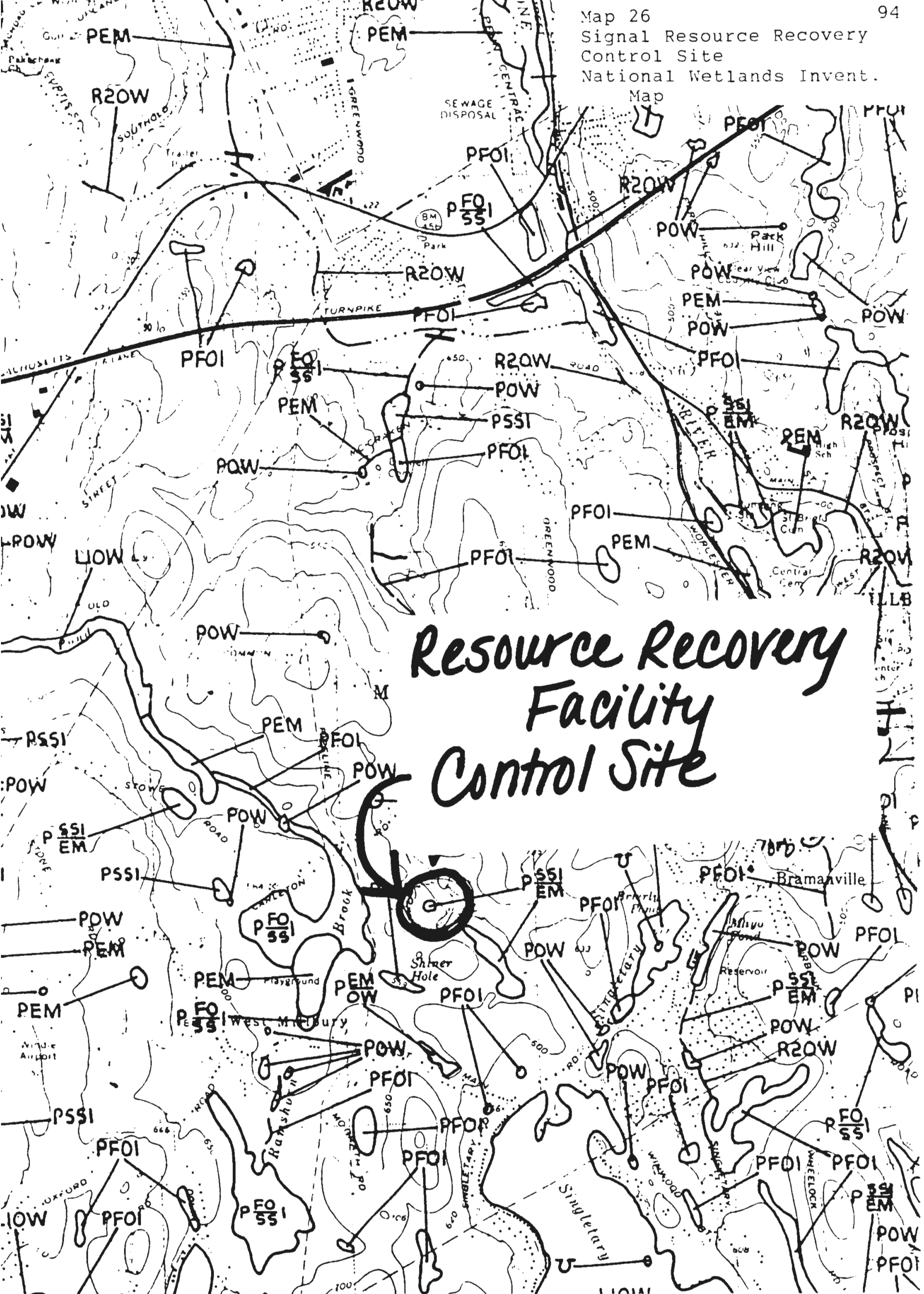
SIGNAL/RESCO RESOURCE RECOVERY PLANT

Control site
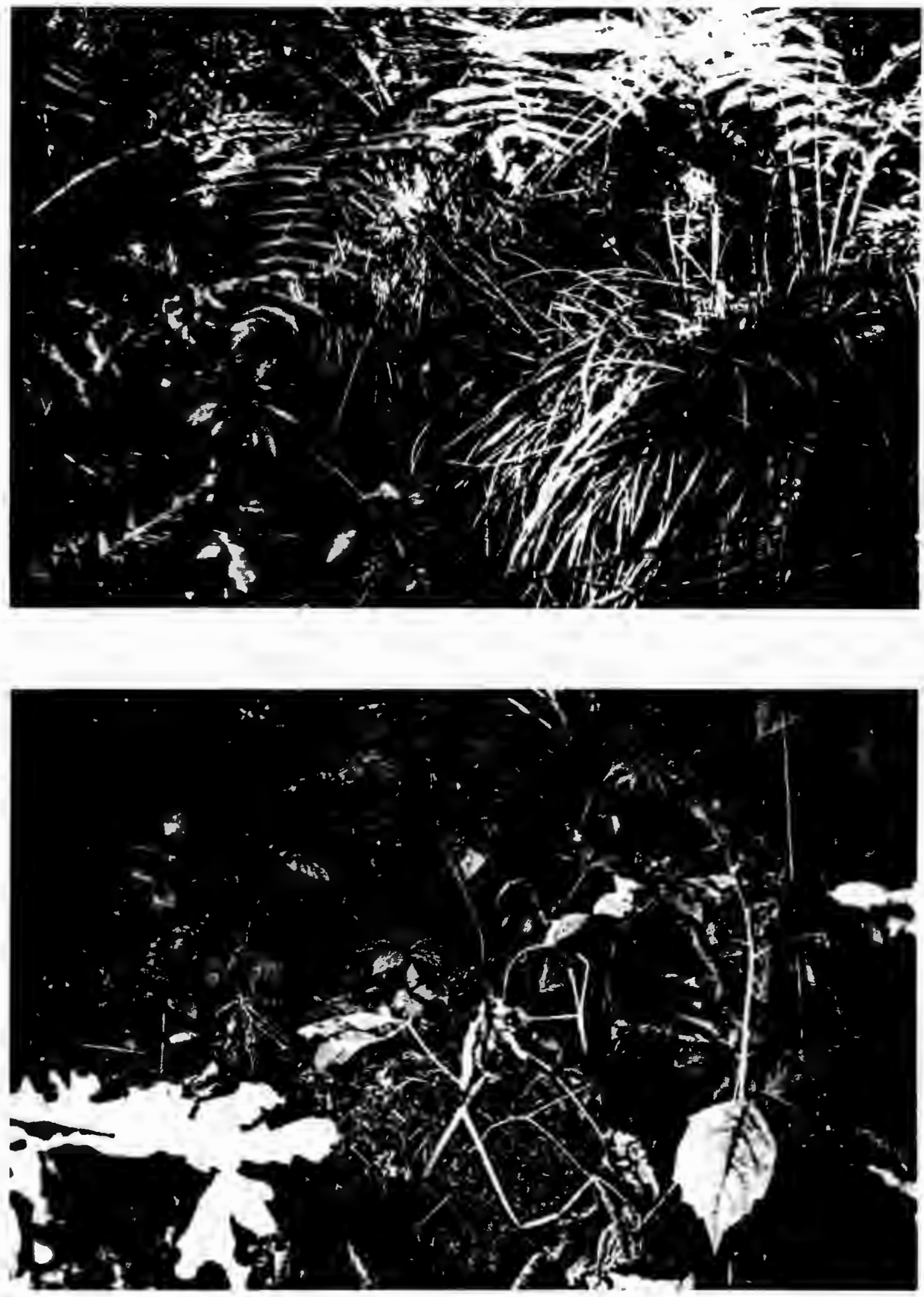
CONNECTICUT SITES

\section{Cheshire Waste Water Treatment Plant}

\section{Created Site}

\section{Purpose}

This wetland was created to offset the wetlands lost to create a dike at the Cheshire Sewage Treatment Plant. Approximately 65 acres of "buttonbush" shrub wetland was filled during the dike construction. In addition, six large bottom land trees were cut down. The creation will be a total of 1.42 acres, including .85 acres of like wetland and .57 acres of side slopes. The created wetland will connect with the existing buttonbush wetland. The wetland will be approximately 650 feet long, narrow at the junction with the existing wetland and widening to 150 feet as it reaches the upland soils (see Map 30).

\section{Description}

This .85 acre shrub wetland was visited on August 17, 1991. The US COE permit was granted in 1986, making the wetland four growing seasons old during the summer of my visit. It is located just off Cheshire Street in Cheshire, Connecticut (Map 27). None of the soils under this creation are hydric, according to the US SCS soil survey (Map 28). According to the local zoning department, the site is zoned $\mathrm{R} 40$, or one-acre residential.

The wetland is associated with the Quinnipiac River, listed as having a " $B$ " water quality (Hall, personal communication: 5/5/92). There were three buildings within 500 feet of the wetland edge. All three were a part of the Waste Water Treatment Plant. This can be seen on Map 29. 
There was no evidence of human activity within the wetland (see photos, page 100). However, in the upland, near the dike and towards the wetland, the area was being mowed. There were also deep tire tracks at the base of the dike. The nearby athletic fields and the Waste Water Plant are buffered from the wetland by a wooded area and the dike, respectively.

The wetland is adjacent to an existing wetland and the vegetative corridor of the Quinnipiac River, creating ample access to the site for wildlife.

\section{Cheshire Waste Water Treatment Plant - Control Site}

\section{Natural Site}

\section{Description}

Since no accessible similar natural site could be found within two miles of the created site, one had to be chosen from outside the two mile limit. The scrub shrub site that was chosen from the National Wetlands Inventory map falls slightly over 2.5 miles away from the artificial wetland, just off Reservoir Road in Cheshire, Connecticut (see Map 31). The site is located behind a small multifamily residential apartment building. The wetland appears to be a field with very little wetland vegetation (see photos, page 105).

The one acre wetland was visited on September 20, 1991. The zoning for the area is reported to be $\mathrm{R}-80$, or two acre residential zoning. Six buildings were noted, all residences, within 500 feet of the wetland edge. There was some trash observed at the wetland site indicated that there is some human activity within the wetland. 
There is a moderate level of activity in the upland as well, from the apartment building and its parking lot.

The wetland appears to be isolated, not associated with any other water bodies. About 50 percent of the site is bordered by a wooded land. Thus, wildlife may access this site. 
CHESHIRE WASTE WATER TREATMENT PLANT

Created Site
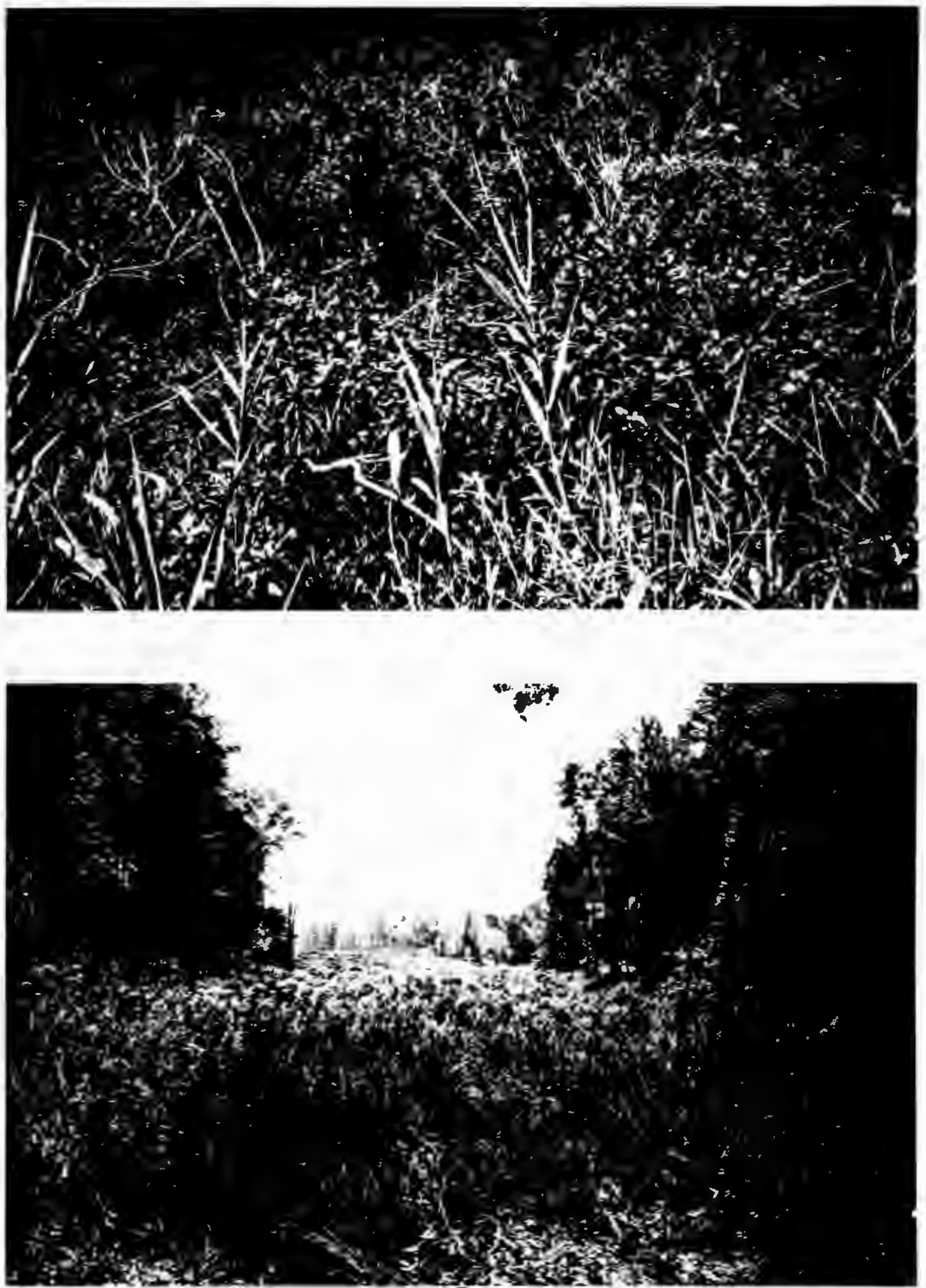


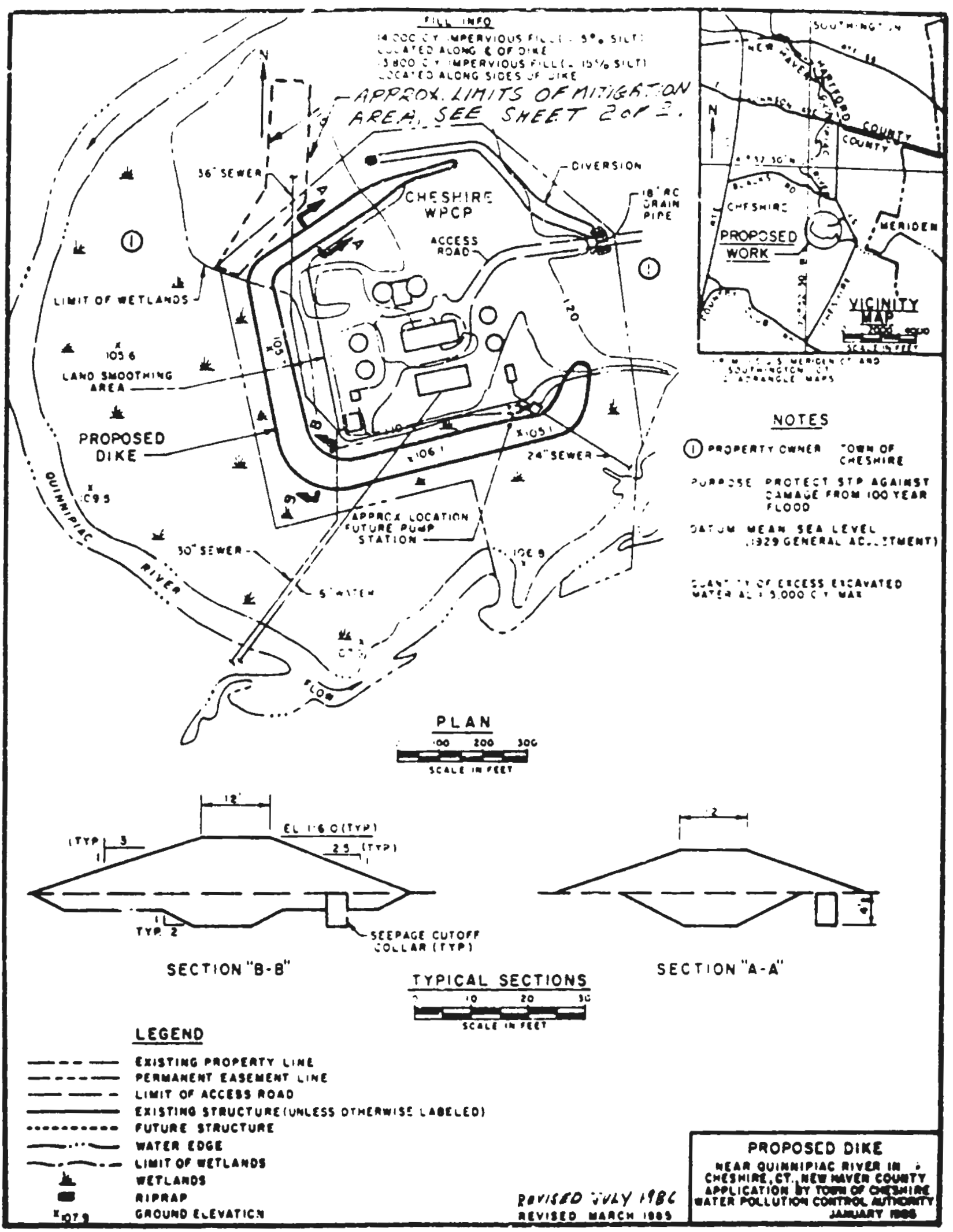


Mitigation Area Map
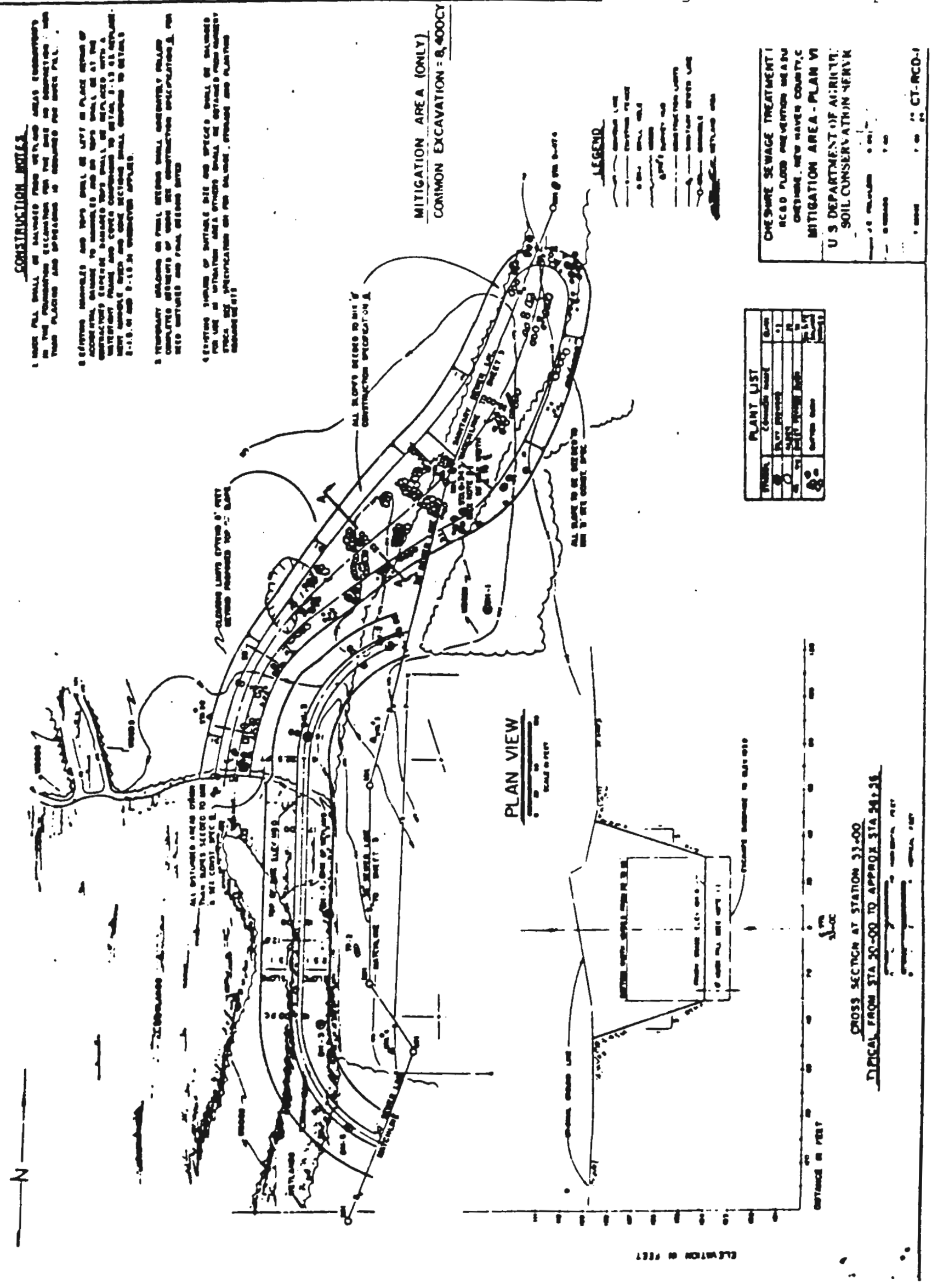


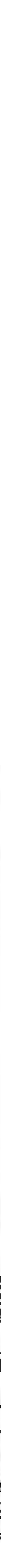


CHESHIRE WASTE WATER TREATMENT PLANT

Control site
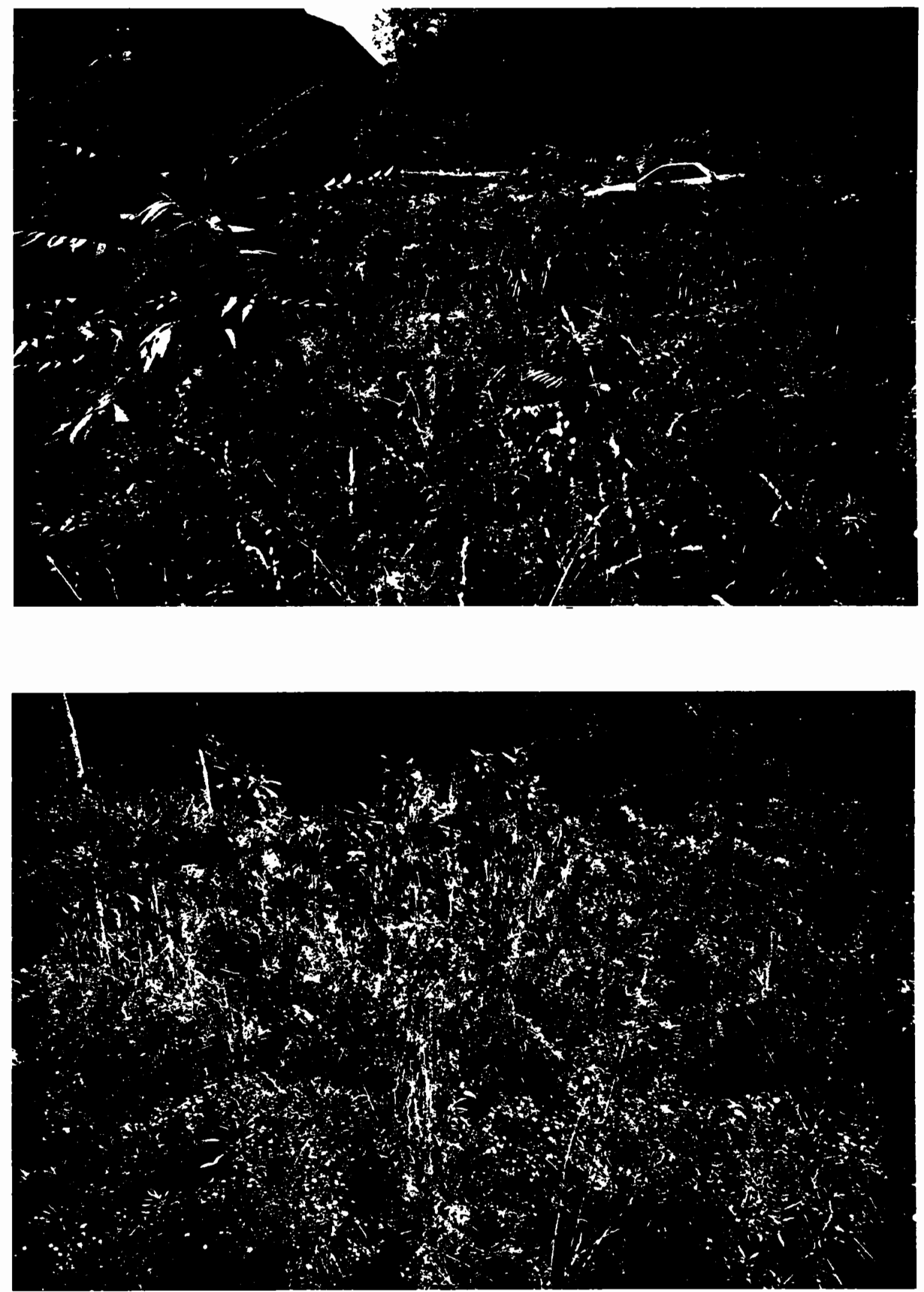


\section{Robertson Airport/Tomasso Nature Park}

\section{Created Wetland}

\section{Purpose}

The created wetland is to provide mitigation for 3.6 acres of emergent/scrub shrub wetlards (with open water areas) filled for a southerly runway expansion at the Robertson Airport. The runway expansion, filled areas, and mitigation areas can be seen on Map 34 . The wetland filled was part of Shade Swamp, a large riverine wetland system, which lies adjacent to the Pequabuck River. Shade Swamp covers about 1000 acres in both the towns of Farmington and Plainville, Connecticut. The filled site was a part of the southern section of the Swamp.

As mitigation for the filled wetlands, a 3.8 acre wetland was created. The artificial wetland was similar to the destroyed wetland: an emergent/scrub shrub wetland with areas of open water (see Map 35). The wetland was also hydrologically connected to Shade Swamp. The area was conserved by the town by turning it into a park. The name of the park is Tomasso Nature Park. The area that the created wetland lies on was once part of the Plainville land fill. The site is located adjacent to the present landfill site (Map 34). The area of the artificial wetland is almost immediately adjacent to the west of the existing wetland.

\section{Description}

This wetland was completed in 1988, making it three growing seasons old. The project site is just east of Johnson Avenue, at the Robertson Airport, in Plainville, Connecticut (see Map 32). Hydric soils cover almost the entire site according to the US SCS soil survey 
(Map 33). The zoning of the area, according to the planning office in town, is restricted industrial. There were fourteen homes counted within 500 feet of the wetland, although they were located outside the of the fenced in wetland.

As described above, the wetland is bordered by a large, contiguous wetland called Shade Swamp and the associated Pequabuck River. The wetland area is set up as a nature park (see photos, page 110), with educational signs, walkways, bridges, and benches. There appeared to be little human activity in the wetland. However, it may be difficult to find evidence of human activities since there are walkways. No trash was seen. There were no visitors on the day of my site visit, a beautiful, sunny, summer day.

There was activity in the nearby upland, with the airport, residences, the landfill and the salvage yard. Planes lift off adjacent to the wetland and often fly overhead. Wildlife do have access to the site through Shade Swamp and along the Pequabuck River corridor.

\section{Robertson Airport/Tomasso Nature Park - Control Site} Natural Wetland

\section{Description}

This wetland was less than one mile away from the Nature Park, off Farmington Avenue, in Plainville, Connecticut (Map 36). The site visit was conducted on September 20,1992. This wetland is a 4.5 acre scrub shrub/emergent wetland (see NWI Map, \#37). According to the local planning/zoning department, the area is $1 / 2$ floodplain and $1 / 2$ restricted industrial. However, the land use of the area is rural residential. When zoning is different from the 
current land use, the New Hampshire Method allows researchers to choose current land use rather than the local zoning classification. Four homes were counted within 500 feet of the wetland edge.

The wetland is associated with the Pequabuck River, as is the created site. The water quality classification of this river is " $B$," according to an EPA specialist (Hall, personal communication: 5/5/92). There could be no human activity detected within the thick brush of the wetland. The wetland is divided by a local road. The photographs on page 115 show the wetlands on either side of the road. Wildlife may access the site along the stream corridor or through the other contiguous wetlands. 


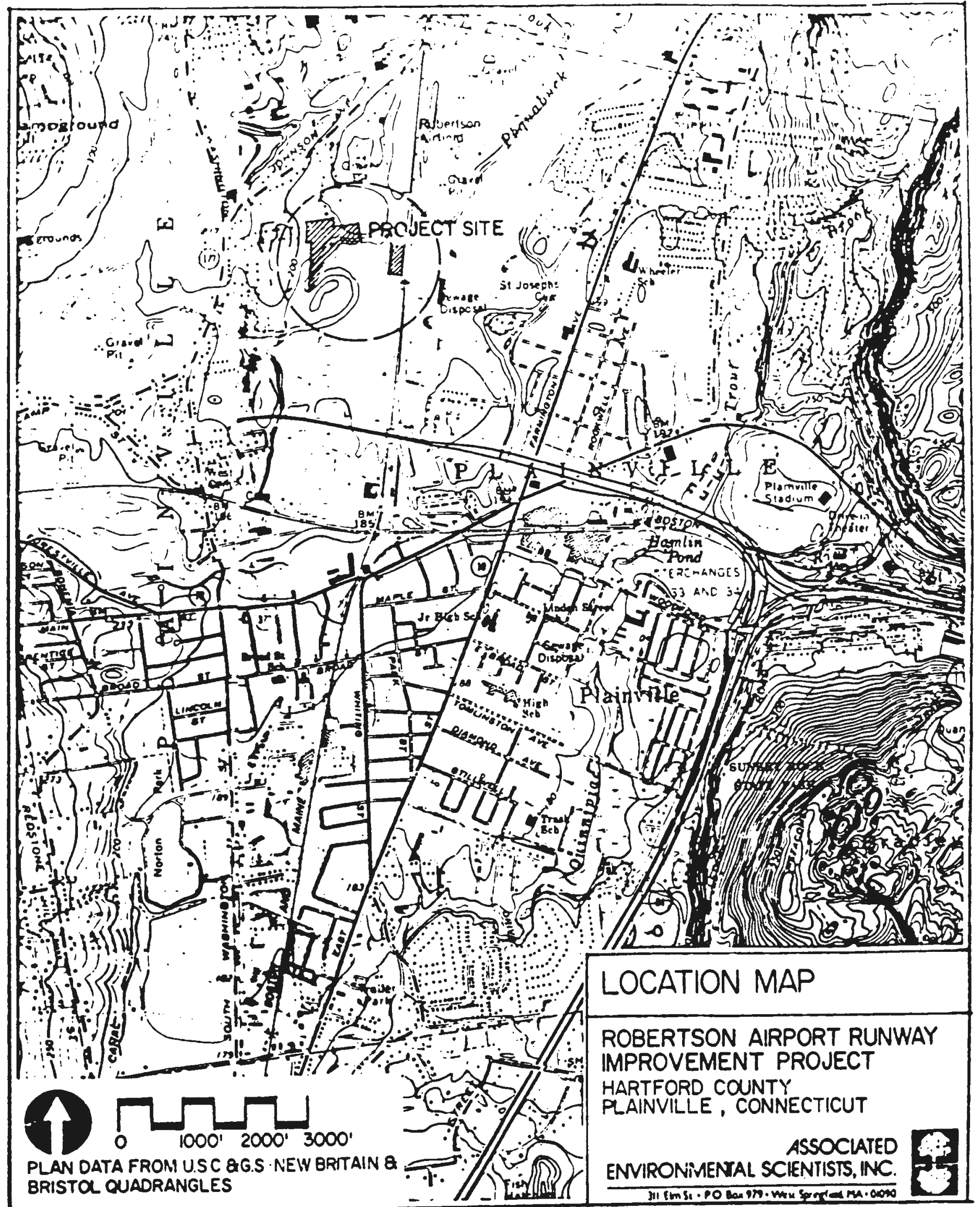


ROBERTSON AIRPORT/TOMASSO NATURE PARK

Created site
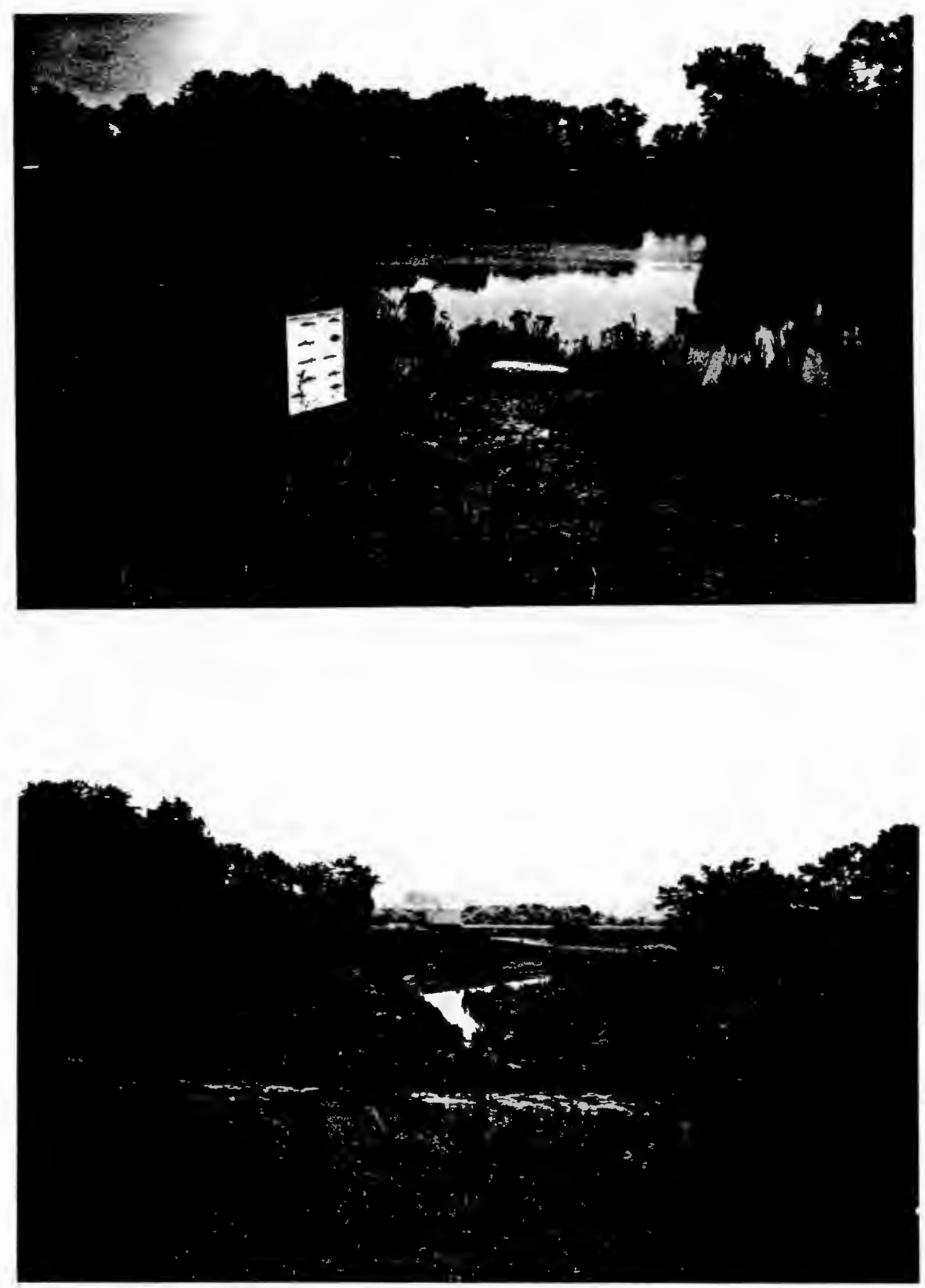


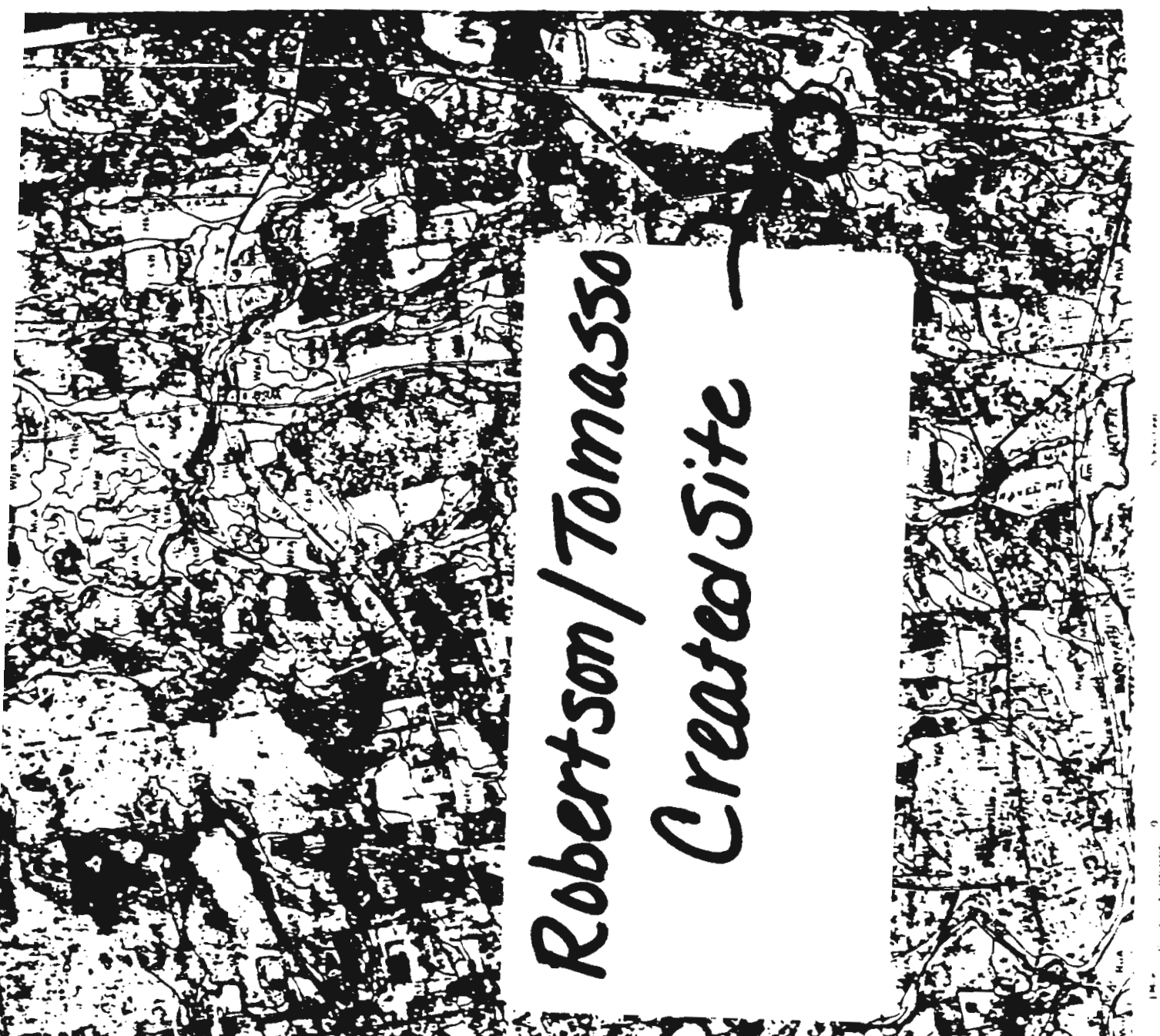

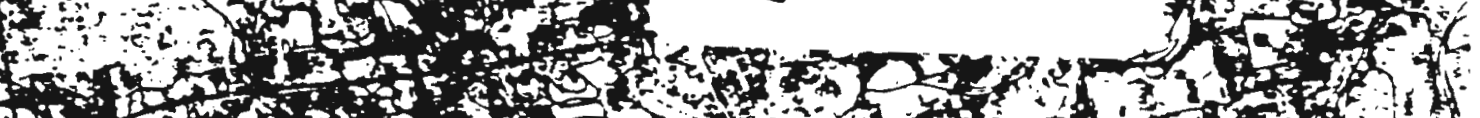
(15) (1) if $x^{2}$ and (1) 17)

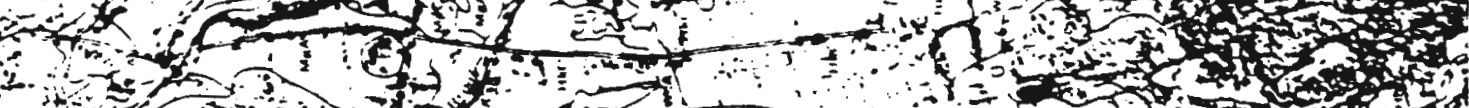

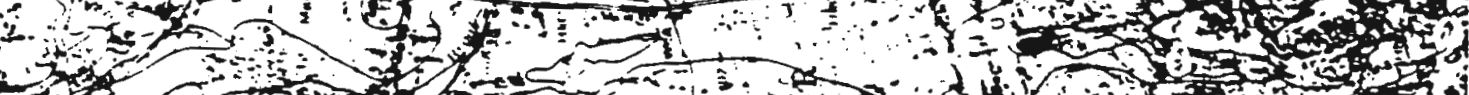
(1) (1)

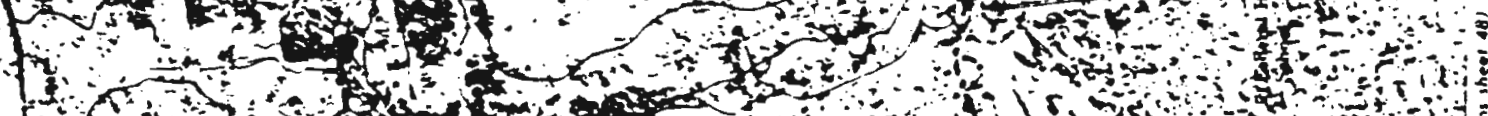
f (f) one en

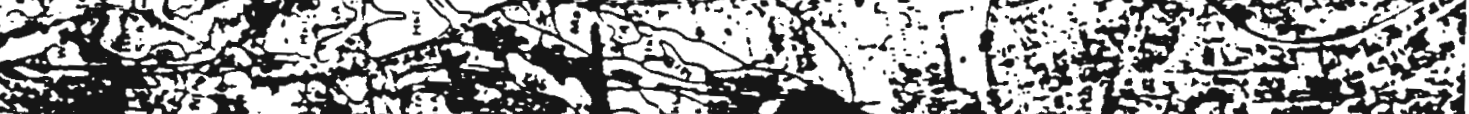
Xes 


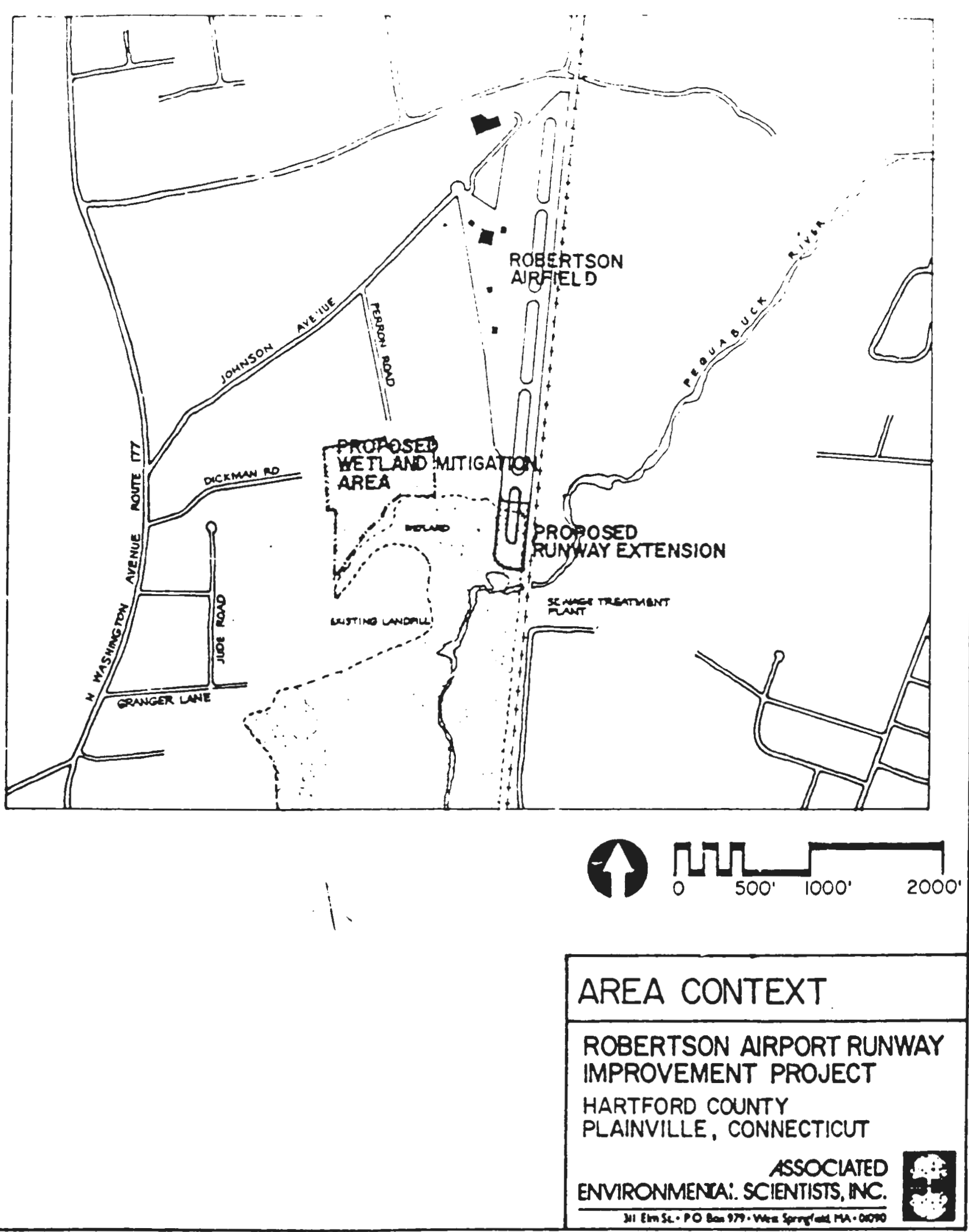




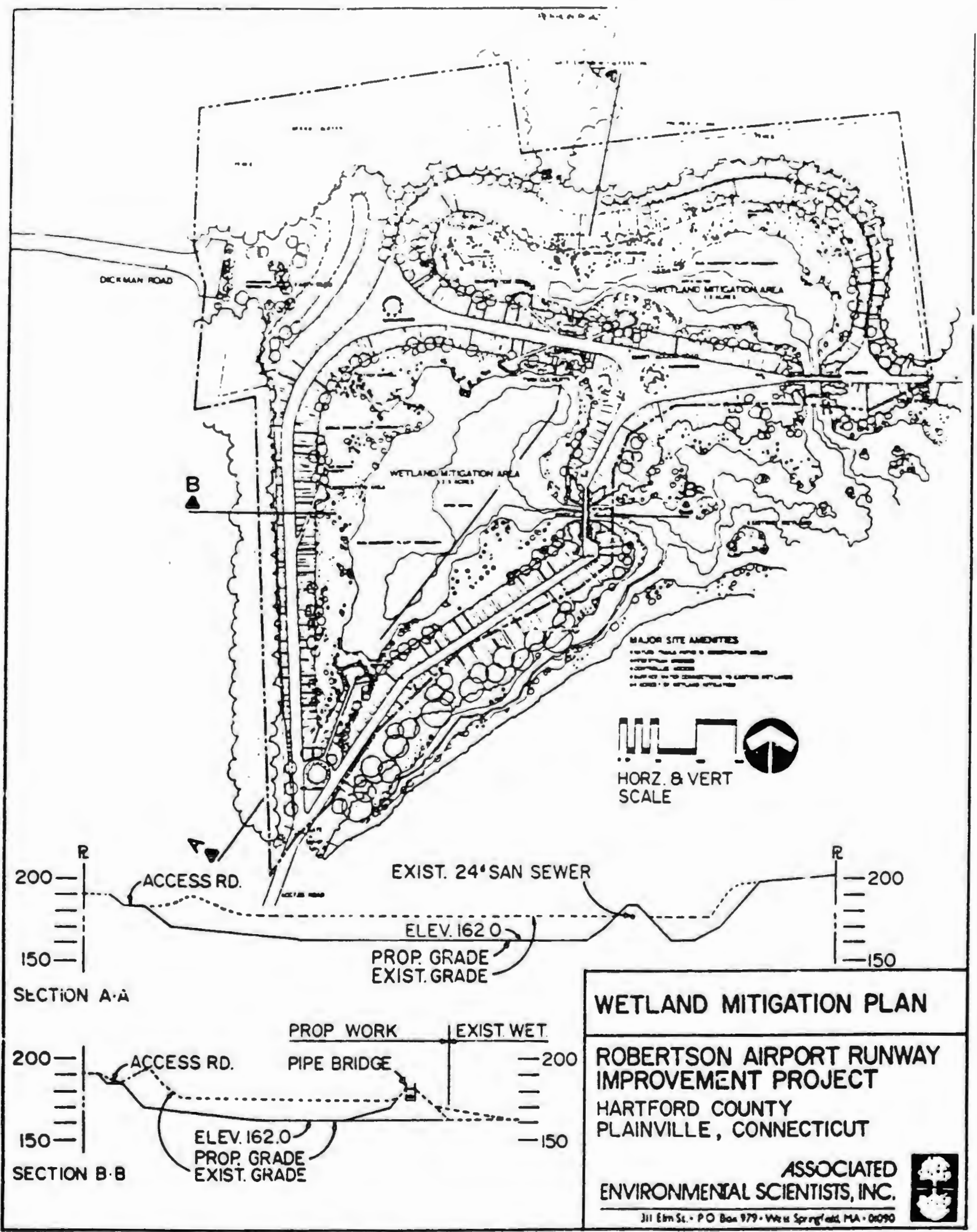


- Robentson/Tomasso

1 Createdsite

0

5

(

Of Robentsong Tomasso 
ROBERTSON AIRPORT/TOMASSO NATURE PARK

Control site
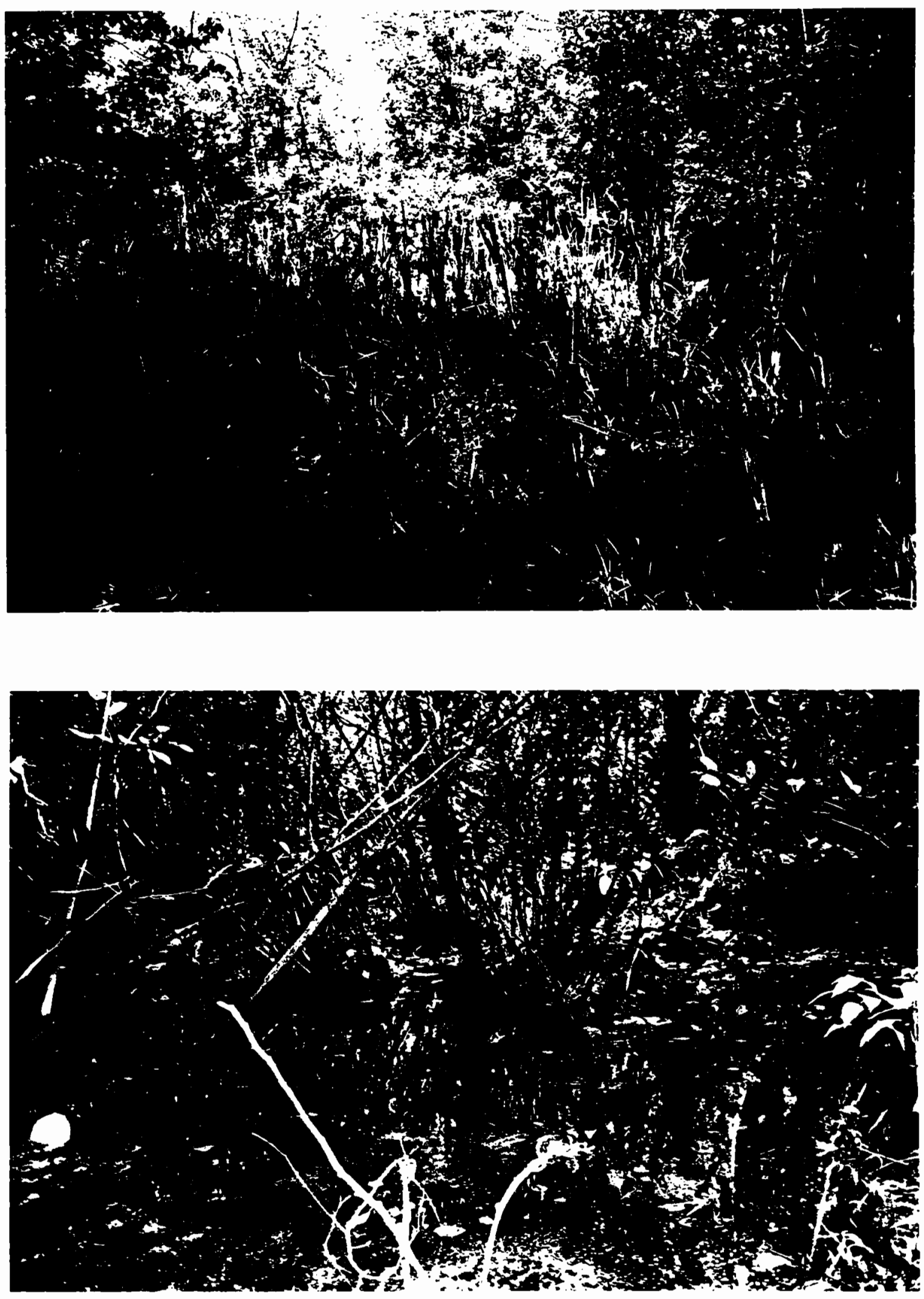


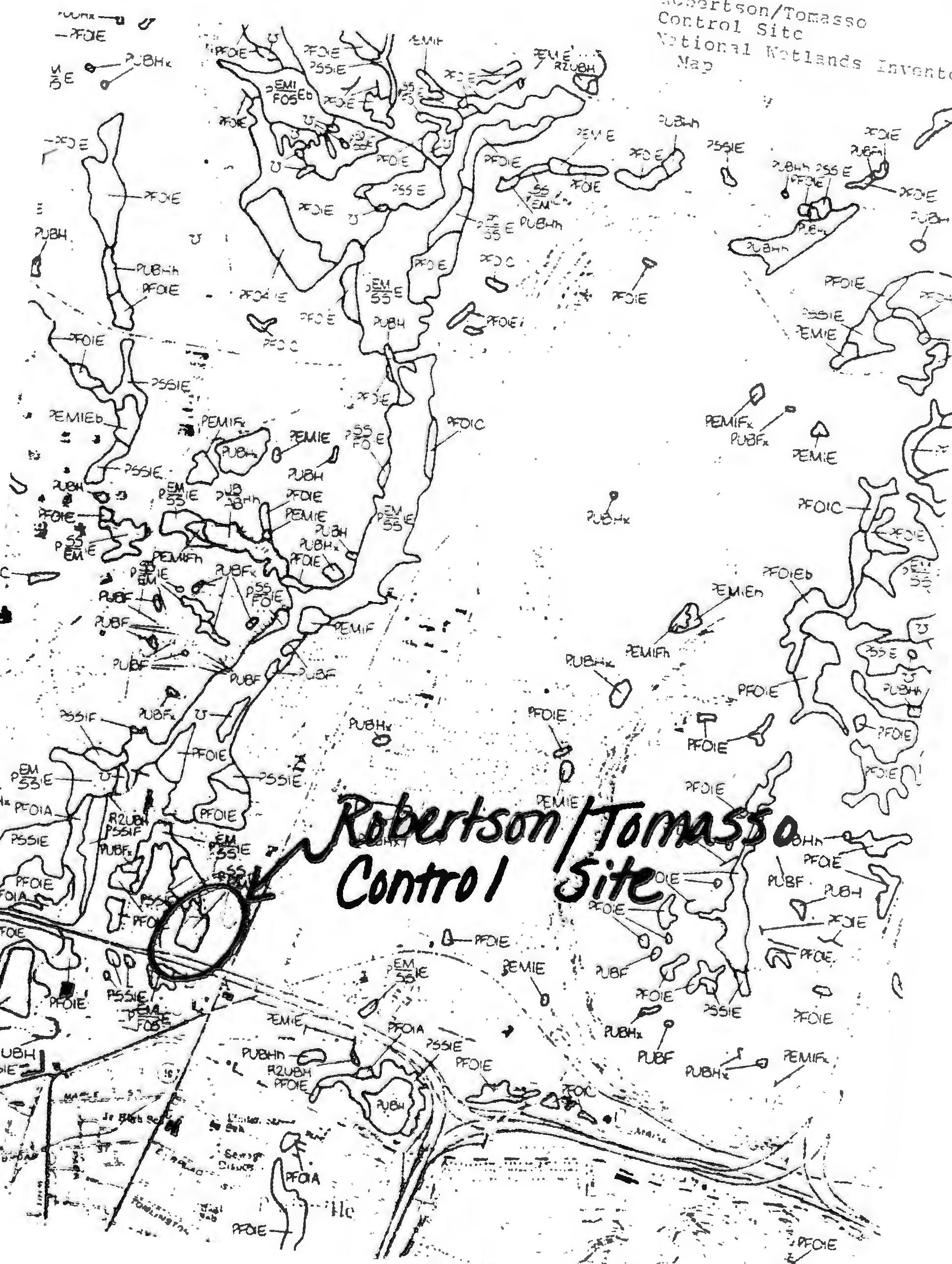




\section{Connecticut Route 7}

Created Wetland

\section{Purpose}

In extending the Route 7 expressway from Route 15 to Grist Mill Road in the City of Norwalk, Connecticut, fill was placed in several wetland sites. About 7.8 acres of existing wetlands were excavated or filled for this project. As compensation for the altered wetlands, 8.1 acres of wetlands were created. Created types included marsh, scrub/shrub and wet meadow habitat. The wetlands will be created in ten separate areas. As recommended to me by a wetland specialist at the US COE, I focused on site \#7, at the Nusco Towers (Map 40).

\section{Description}

This site is located on Indian Hill, just west of the existing Route 7 and north of the Merritt Parkway (see Map 38). This emergent/scrub shrub, 3.1 acre creation is broken into two sections, or basins (see Map 41). I visited the site on August 17, 1991, three growing seasons after it was completed.

Site \# 7 is located along the NUSCO power lines, between Louden Street and Seir Hill Road. To create this wetland, the cliffs were blasted away around the power lines to a low elevation. By attempting to avoid the power lines, the state divided the created wetland in half. This unusual wetland is surrounded by high, vertical cliffs and is adjacent to the new Route 7 (not yet completed at the time of my site visit). This is clearly depicted in the photographs on page 121. 
Less than 25 percent of the soils at this site are hydric, as determined by the US SCS soil survey (Map 39). The zoning of the area is $\mathrm{R} 40$, or one-acre residential. The isolated wetland is connected via a culvert under the highway to the pond and existing wetland on the other side of the highway. Other than these culverts, there is no wildlife access to this site. The steep cliffs and highway surround the wetland.

Ten buildings were noted within 500 feet of the wetland edge. The buildings were multi-family apartment buildings, beyond the fence on the opposite side of the road. There was no evidence of human activity within the wetland. There was little activity in the upland on the weekend day that I conducted my site visit. However, as soon as the highway is completed, the activity in the upland will dramatically increase.

\section{Connecticut Route 7 - Control Site}

\section{Natural Wetland}

\section{Description}

This wetland is only slightly over two miles away from created site. The site visit to this wetland took place on September 30, 1991. The 3 acre emergent/scrub shrub wetland is north of Gruman Hill Road, on Copts Brook (Map 42). Over 50 percent of the soils here are hydric, according to the US SCS soil survey (see Map 43). The zoning is $\mathrm{R} 40$, rural residential. There were five houses located within 500 feet of the wetland edge.

The level of human activity in the wetland was low. There was no evidence of fill, although there may have been a small amount 
around the power lines that go through the site. One local road crosses the wetland. The road and surrounding residences only amounts to slight activity in the upland surrounding the natural wetland.

Wildlife have access to this site along the stream corridor. However, it would be difficult for them to access the area because of the dense phragmites that have taken over the site (see photos on page 126). 

CONNECTICUT ROUTE 7

Created Site \#7
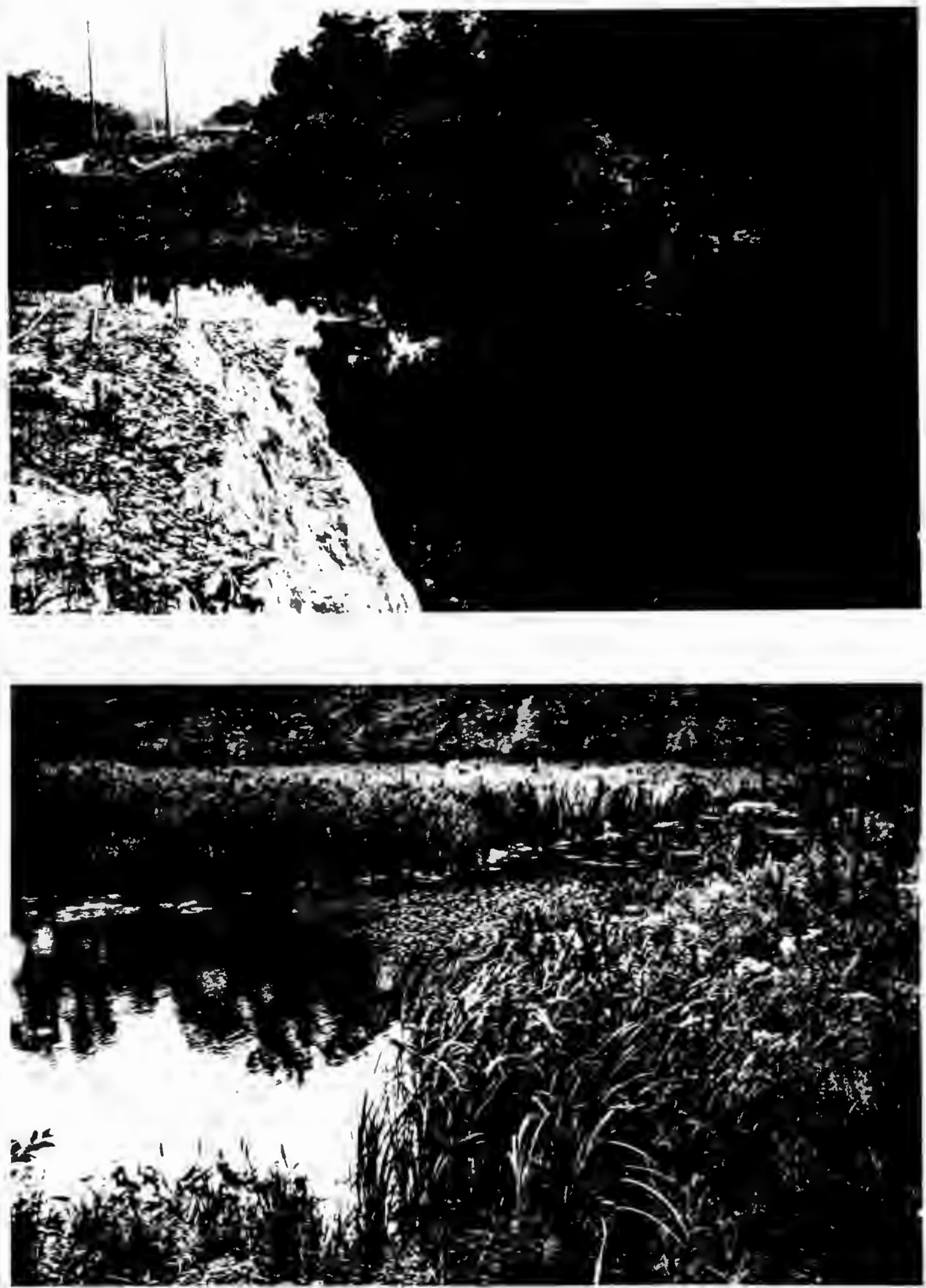


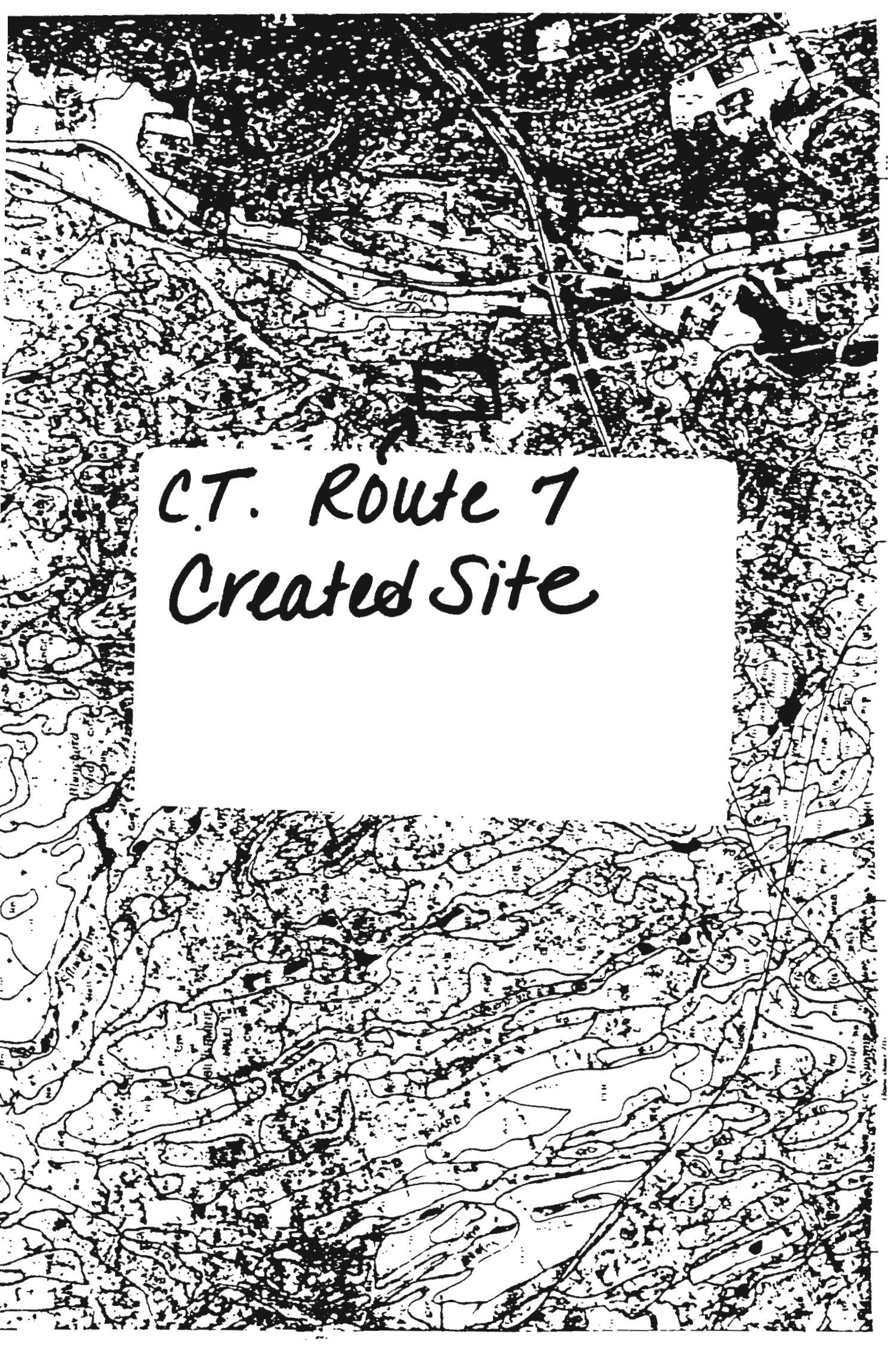


W! ITUN

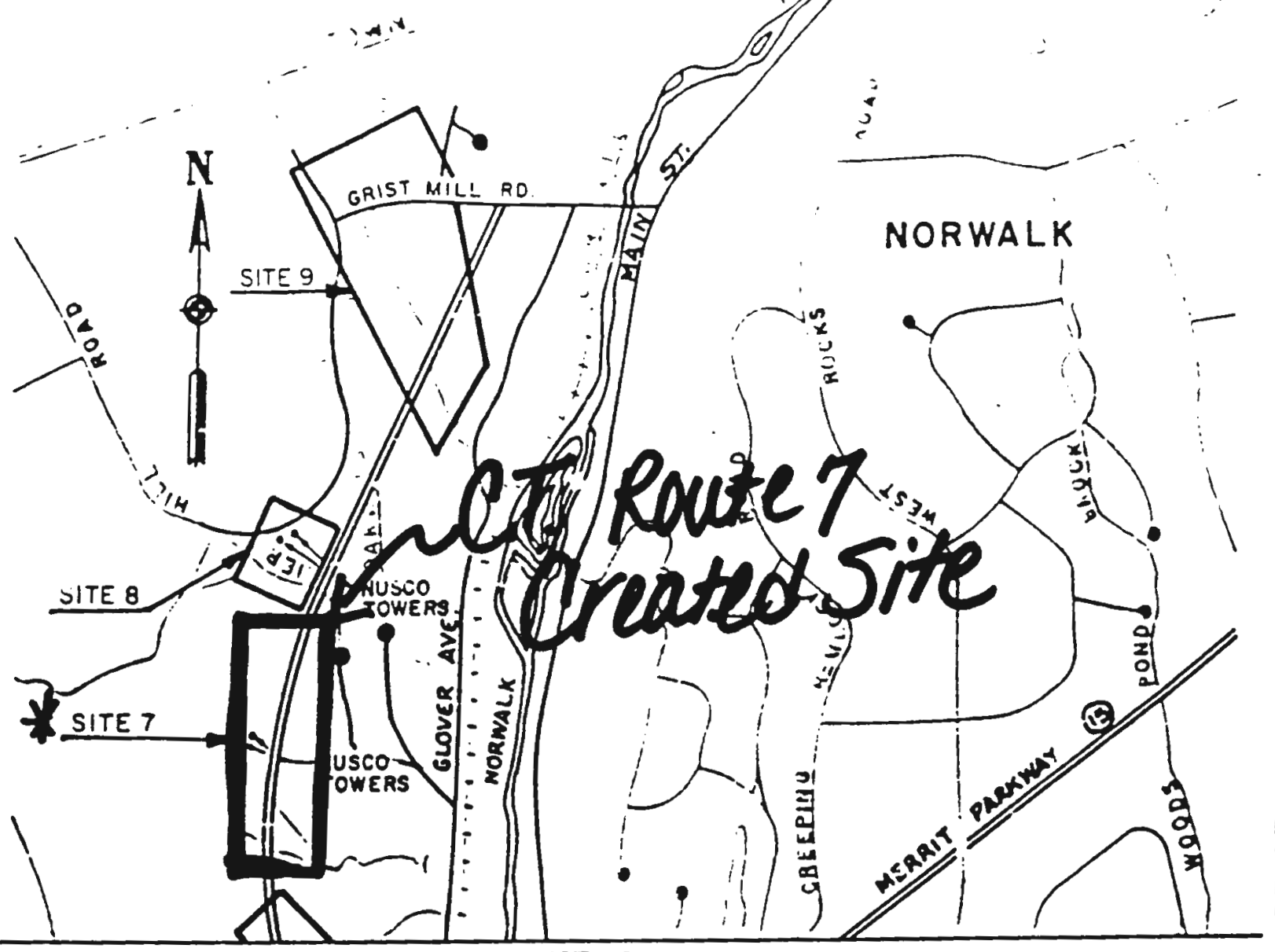

MATCH LINE PLATE 2 SITE LOCATION

LOCATION PLAN

$\checkmark 1000500 \quad 0$

1000

2000

SCALE IN FEET

TATE PROJECT NO. 102-190 ELOCATION OF U.S. ROUTE 7 ORWALK

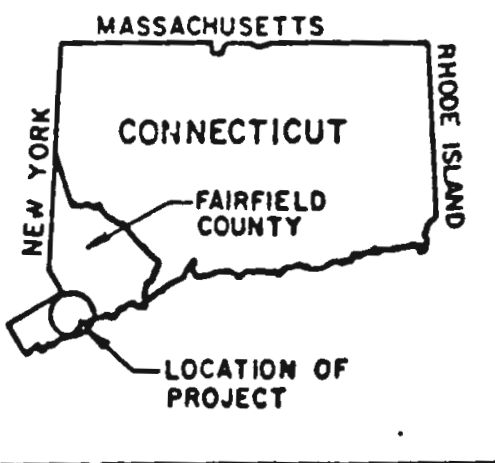

ILAND - WETLAND

PLATE 3 OF 26

DATE: NOV., 1986 
QRFATED WEILAND - PLANT SPECIES PRESENT Mr M $<1$

MARSH AREA

Water Plantain

Soft Rush

P) Arrumar Lily

Broad-leaved Cattail *

Pickerelweed (P)

P) hiater Lily

BANK AREA

Rugosa Rose (P)

Winterberry (P)

Serviceberry (P)

White Pine (P)

Showy Tick-Trefoil

Honeysuckle (P)

Boneset

Red Maple (P)

Ch: Route 7

crertec site

Mitigation pIantinr Flan

Crab Apple (P)

Clethra (P)

Fed cedar (P)

WET MEADOW AREA

Barnyard Grass

Blue curls

Beak Rush

Bugleweed

Blue Vervain

Foxtail

Spike Rush

Soft Rush

Smartweed
Highbush Bluebern (P)

Snartweed*

Silver Maple (P)

Tickseed Sunflowers

Siberia Dogwood (P)

Notes: (P) - Planted, * - Dominant

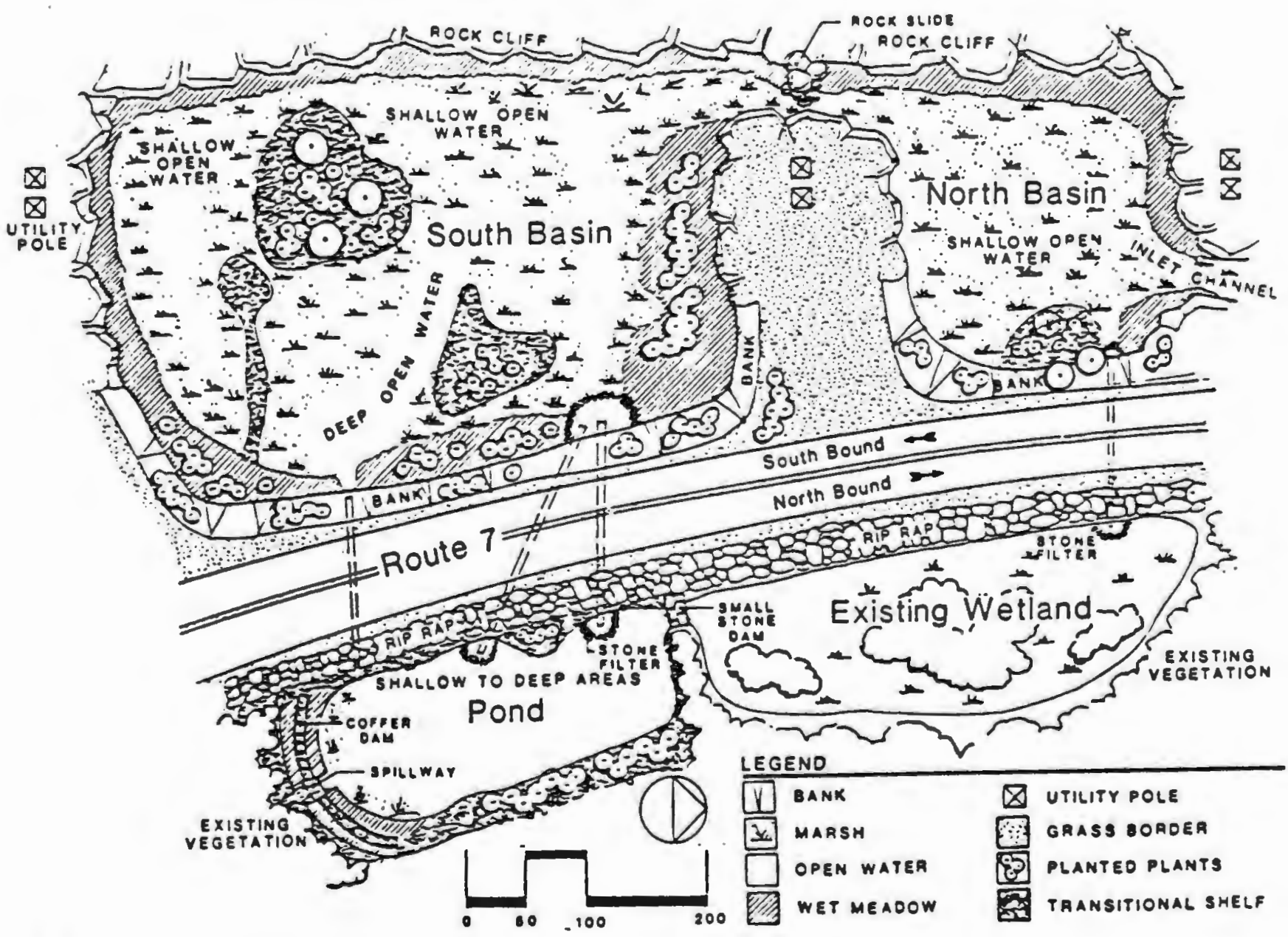

Beggars Tick

Narrow-leaf willow herb

Boneset

Rice cutgrass 
CONNECTICUT ROUTE 7

Control site
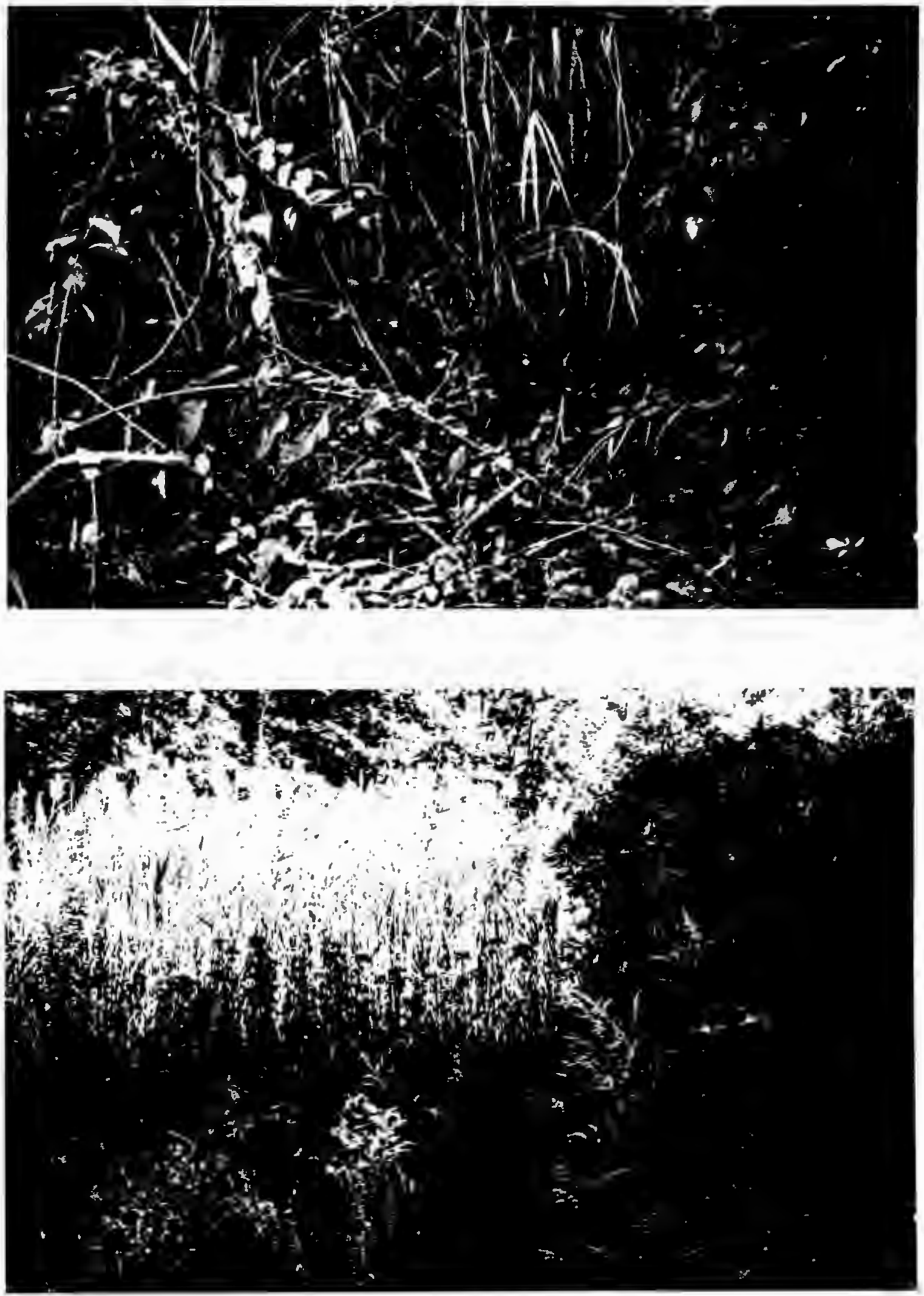


\section{Southbury Travel Center}

\section{Restored Site}

\section{Purpose}

Professional Properties Associates applied for a permit to place fill in approximately 1.9 acres of wetlands in conjunction with the development of "Phase 2" of a travel center, called Southbury Travel Center. The Travel Center is located just of exit 14 of Interstate 84, at the southwest corner of CT Route 172 and Main Street South, in Southbury Connecticut (see Map 44). Later, the approximate fill area in wetlands was reduced to 1.1 acres. The filled wetland was a disturbed wet meadow with some wetland shrubs occurring. As partial mitigation for the 1.1 acres of fill, an adjacent .65 acre wetland restoration was completed.

The wetland to be restored was an adjacent formerly filled wetland. The restoration was similar to the filled wetland, with scrub shrub, marsh, and pond habitat types (Map 45). The restored wetland was designed to perform three functions; wildlife habitat, water quality renovation, and sediment control during construction.

\section{Description}

This site was visited on August 17, 1991, approximately three growing seasons after the wetland restoration was completed. According to the US SCS soil survey for the county, over 50 percent of the soils at the site were hydric (see Map 46). The local zoning office reported the zoning of the site to be B2E, a business zone. There were nine buildings counted within 500 feet of the wetland edge. 
The site consisted of an open water pond with marsh and scrub shrub vegetation. The restored site can be seen in the photographs on page 132. The restored wetland site is surrounded by roads and the Travel Center on all sides, creating a significant disturbance in the adjacent upland. Within the wetland, there was evidence of disturbance, with an old silt fence still in tact as well as rusted cables and barrels at a corner of the site. The wetland is surrounded by a high hill, called Ichabod Hill, on one side. Interstate 84 travels up this hill on one side of the wetland. It appears that runoff from the roads and hills will end up in the low-lying restored wetland.

Mowing of the adjacent upland is evident on the edges of the wetland. Phragmites have taken over much of the existing southwestern wetland. Farming is taking place across the street though there is no evidence of draining for agricultural or any other purpose. There is no corridor for wildlife to gain access to the site. The site is surrounded by roads, though they are not immediately adjacent to the wetland itself.

\section{Southbury Travel Center - Control Site}

\section{Control Site}

\section{Description}

This site is located about a quarter mile away from the restoration at the Travel Center. The natural site is an emergent/scrub shrub wetland, southwest of the Southbury Travel Center (see Map 47). The soils are mostly hydric according to the US SCS soils survey for the county (Map 46). This site is also zoned B2E, a business district. 
An unnamed tributary of the Pomperaug River runs through the wetland. Only one building was within 500 feet of the wetland edge. The wetland is located at the base of Horse Hill. Thus, wildlife may access the site along this woodland area. The wetland is naturally occurring, receiving its source of water from the stream, as well as from runoff from the hill and the adjacent roads.

There was little human activity noted within the mucky soils of the control wetland (see photos, page 136). However, there was a lot of trash noted in the immediately adjacent upland. The trash included rusted barrels and cans, an old bike, and some major appliances. The two adjacent roads and the trash indicated a high amount of activity in the upland. 
132

SOUTHBURY TRAVEL CENTER

Restored Site
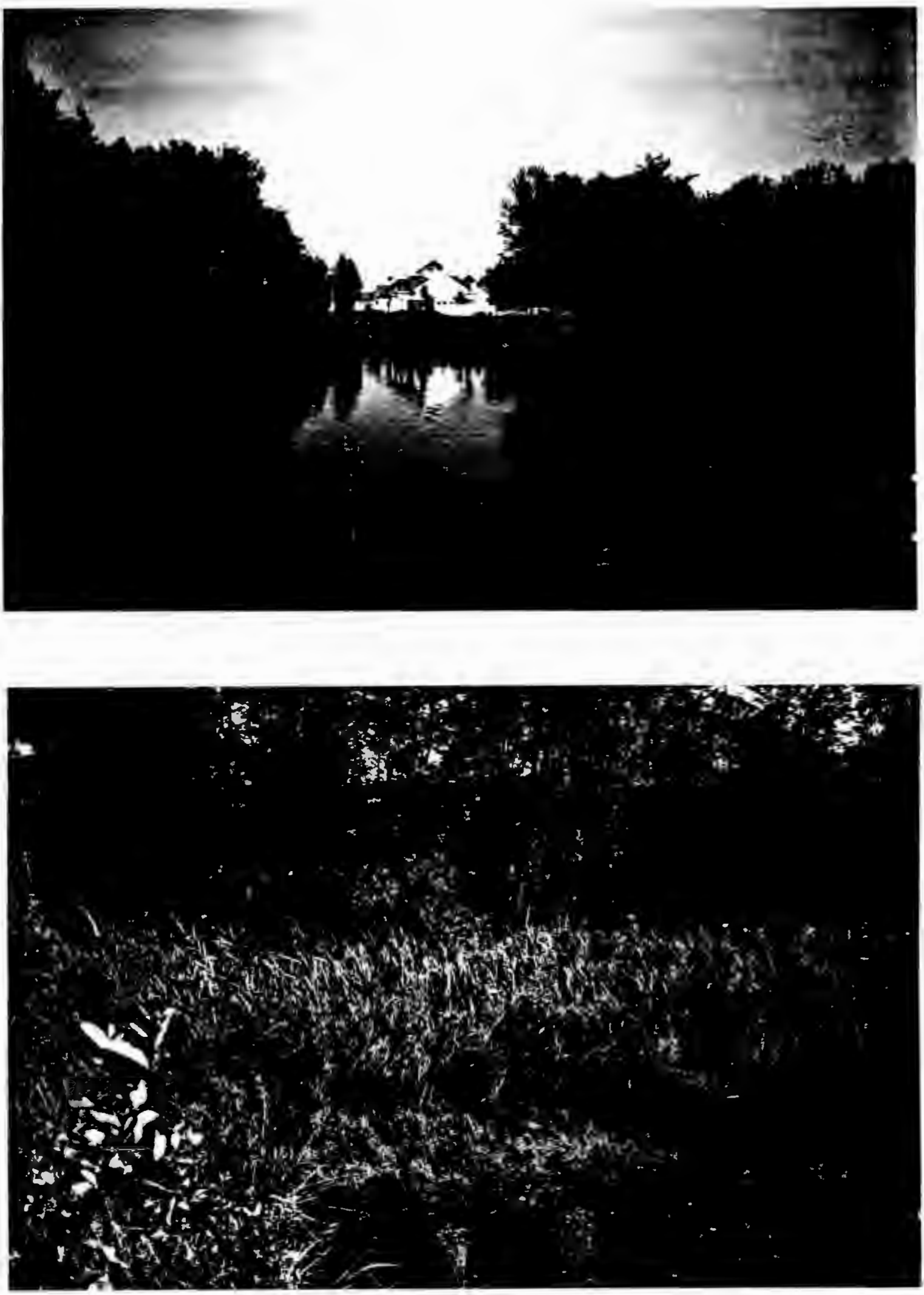


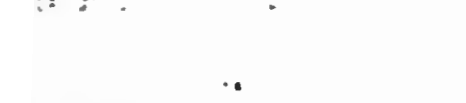

$\because \because \therefore \ldots$
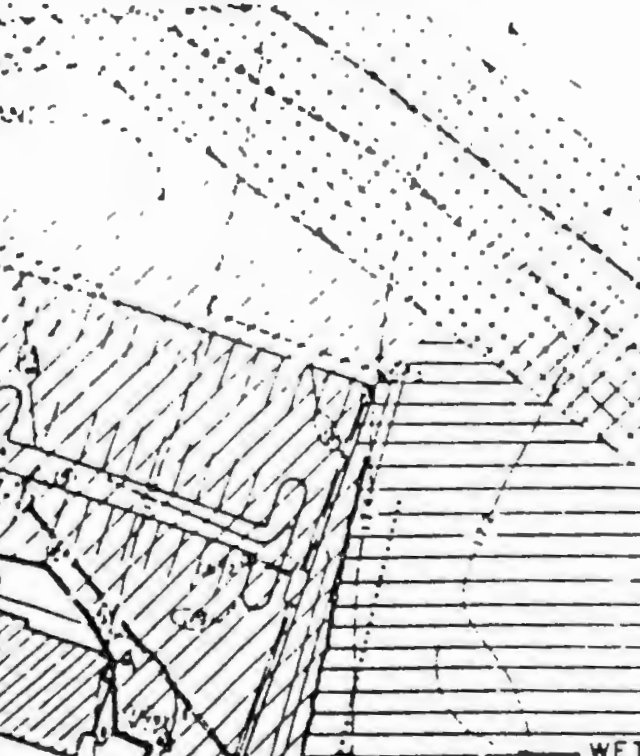


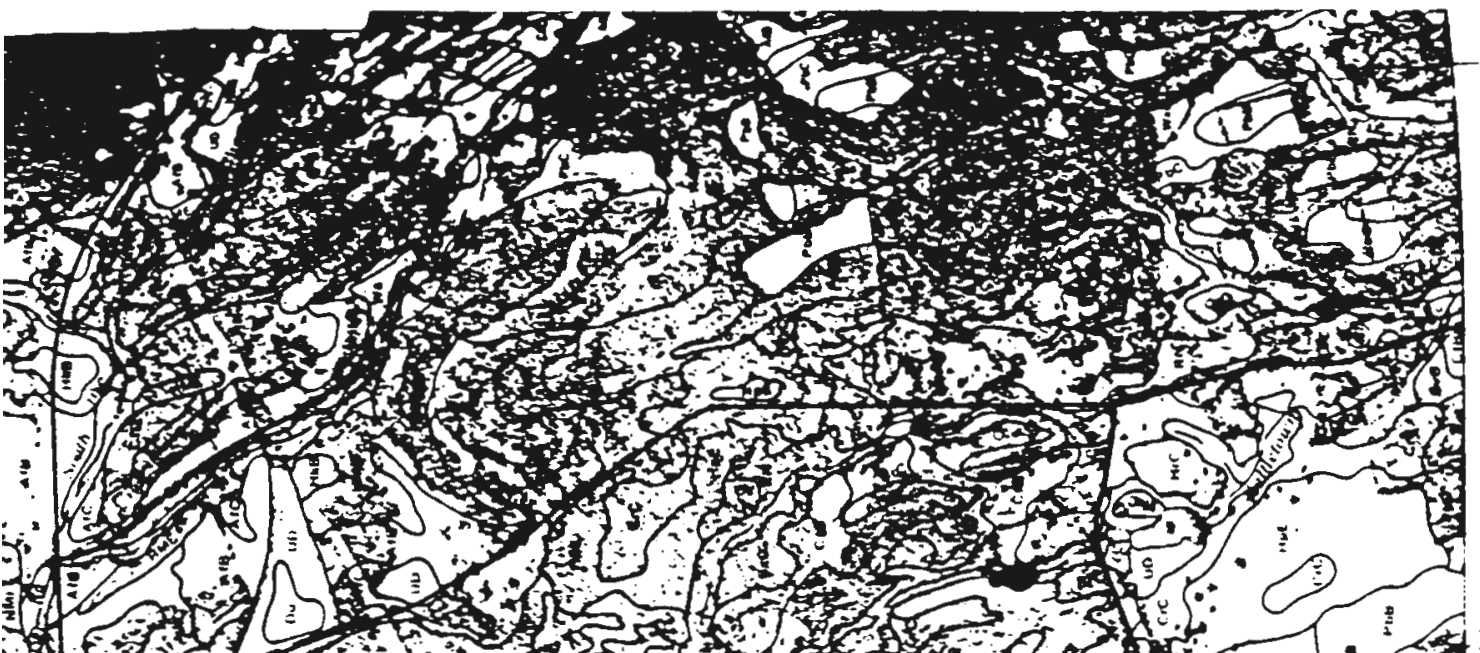
(1)

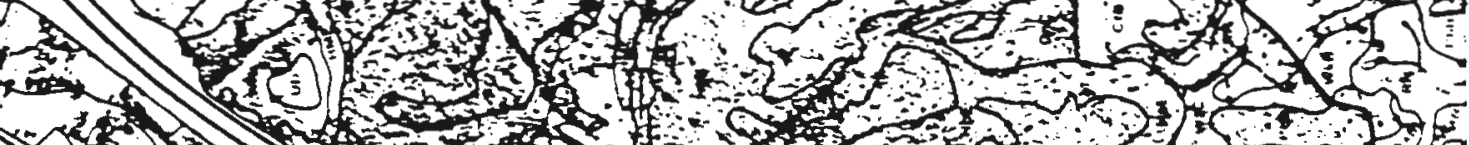

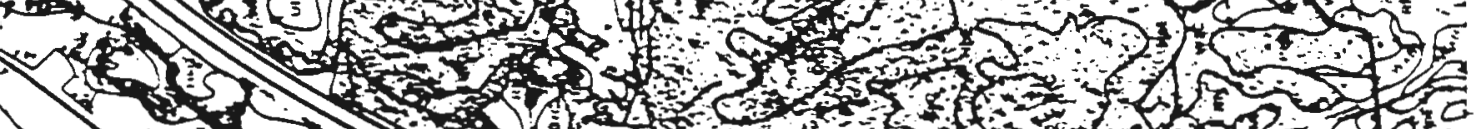

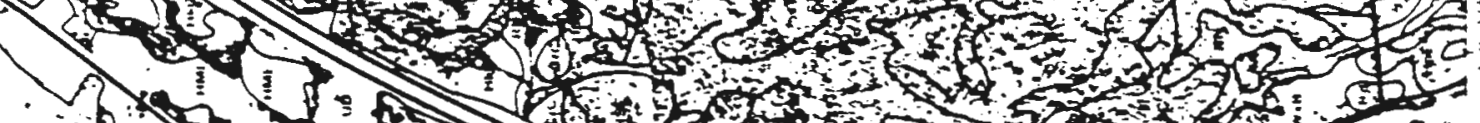
(1)

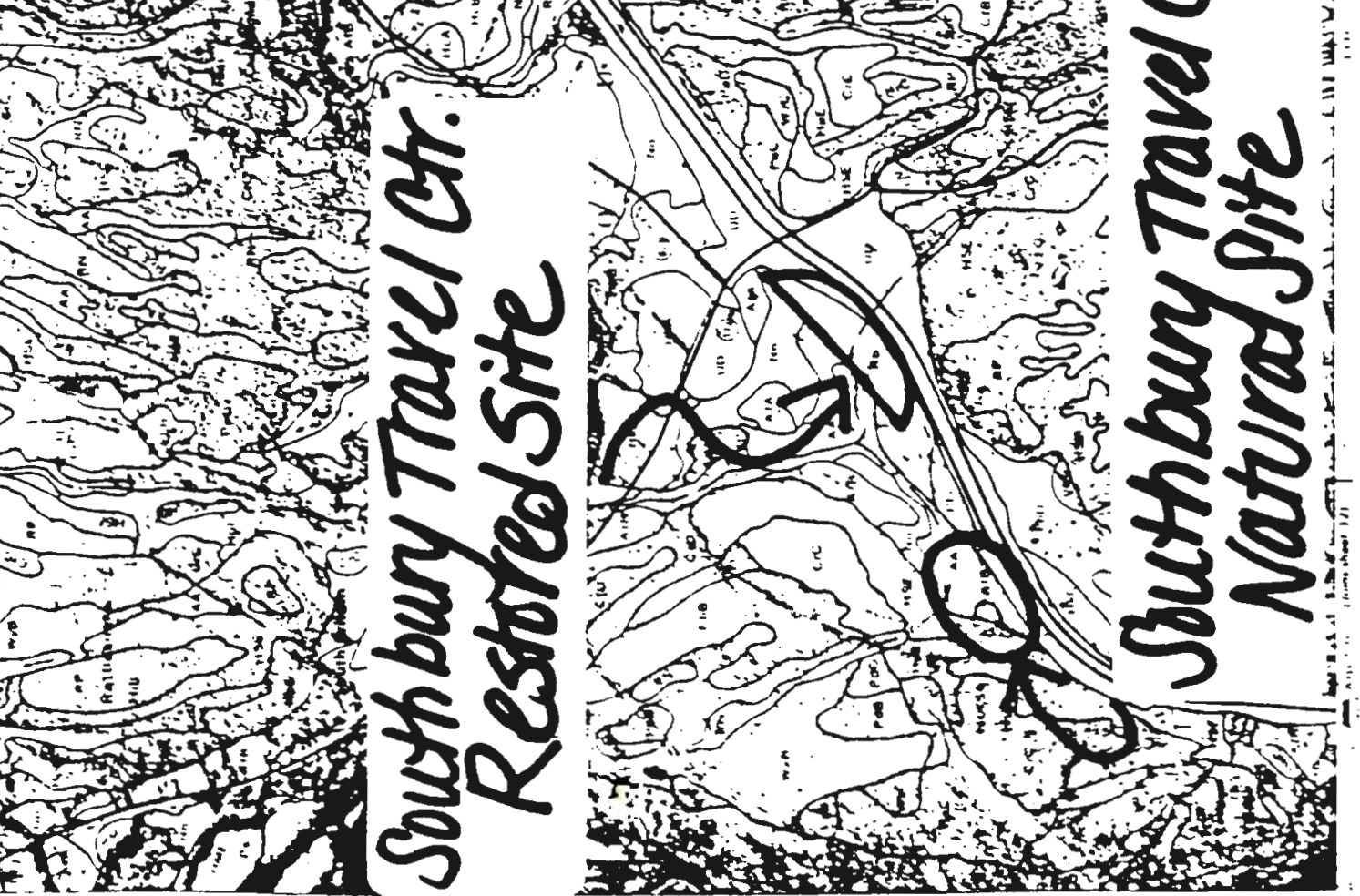




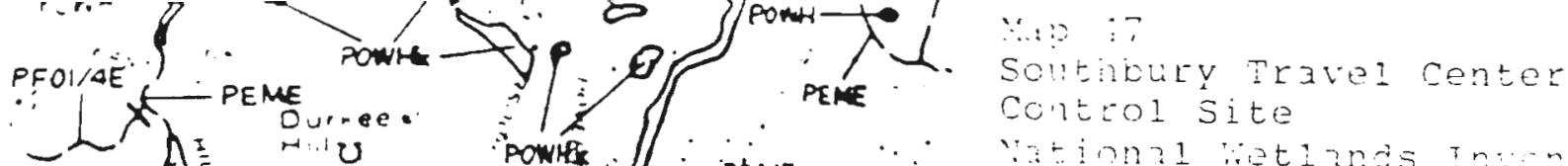

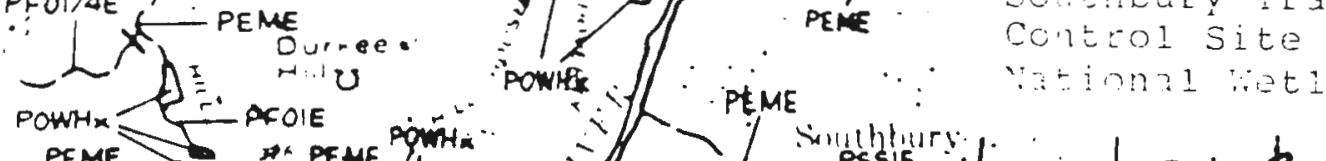
(1) and 
SOUTHBURY TRAVEL CENTER

Control site
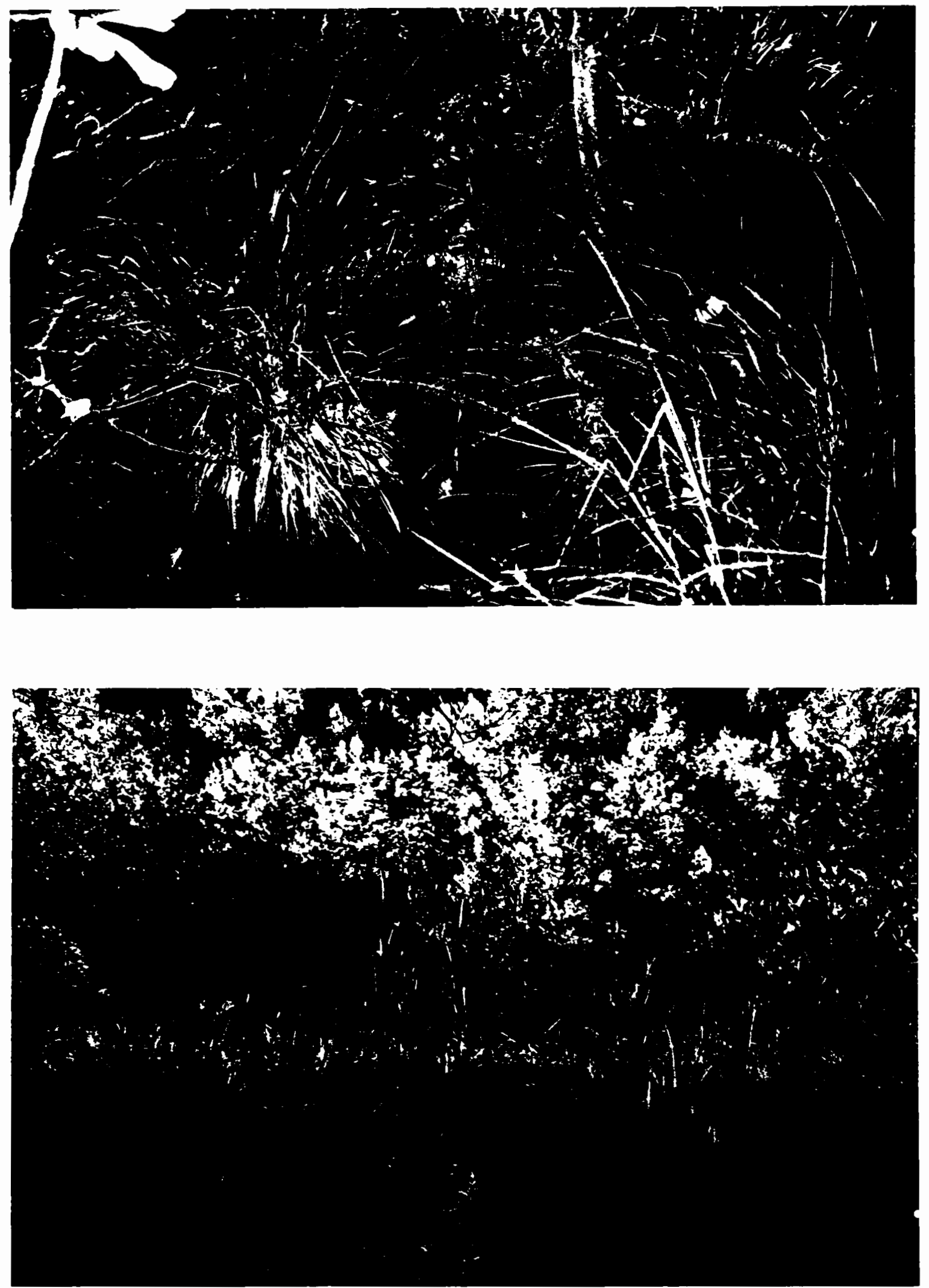
Chapter Seven

\section{DATA ANALYSIS}




\section{Chapter Seven}

\section{DATA ANALYSIS}

\section{Data Specification}

The hypothesis (wetlands created or restored by humans cannot be satisfactory replacements for natural wetlands) was evaluated through an analysis of data collected in the field (as described above), together with library research, personal interviews with wetland specialists, and research of the mitigation proposals.

I researched the mitigation proposals in June and July, 1991. The permits that were available for the created/restored sites can be seen in Appendix B. I conducted the site visits during the height of the growing season, on weekend days from August 10, 1991 though September 30, 1991. The field sheets for each site can be seen in Appendix A.

The water quality information was obtained from a water quality expert at the US EPA - Region One, (Hall, personal communication: 5/5/92), for the waterbodies associated with each wetland in the study. The water quality information is listed in a table on the top of the following page. 
Table 3

\section{WATER QUALITY CLASSIFICATIONS}

Waterbody

1. Sagamore Creek

2. Salmon Brook

3. Porcupine Brook

4. Spicket River

5. Crook Fall Brook

6. Long Brook

7. Deep Brook

8. Broad Meadow Bk.

9. Ramshorn Brook

10. Quinnipiac River

11. Pequabuck River

12. Copts Brook

13. Pomperaug River
Wetland Associated With It

Class

Portsmouth H.S. \& Control Site

B

Bradgate Associates (Control) B

Rockingham Mall

Rockingham Mall (Control)

B

Woonsocket Route 99

Woonsocket Route 99 (Control)

B

A

Arthur Nemon (Control)

B

Signal/Resco Resource Recovery

B

B

Signal/Resco Resource (Control)

B

Cheshire Waste Water Tmt. Plant

B

Robertson/Tomasso \& Control Site

B

CT Route 7 (Control)

B

Southbury Travel Center

The soils information was either requested from the appropriate regional US Soil Conservation Service office, or was gathered from the US SCS soil survey itself. The soils maps for each site can be found with the according wetland site description above. Soils information could not be obtained for two sites; the Robertson Airport/Tomasso Nature Park Control Site and the Signal/Resco Resource Recovery Plant Control Site. Thus, to determine if the hydric soils comprised; a). more than 50 percent, b). between 25 and 50 percent, or $c)$. less than 25 percent of the wetland site, I based my decision on the results of a similar site.

For example, the Signal/Resco control site was adjacent to a pond and had very mucky soils present, just like the Woonsocket 
Route 99 control site. Since the Woonsocket Route 99 control site had over 50 percent hydric soils on the site, I assumed the same was true for the Signal/Resco control site. For the Robertson Airport/Tomasso Nature Park control site, the conditions were similar to the Bradgate Associates control site. Both were located adjacent to a stream, along the stream corridor. Again, since the soils information was not available for the Robertson/Tomasso site, I assumed the hydric soils covered over 50 percent of the site, as they did at the Bradgate control site.

Zoning information was gathered in the Spring of 1992. Phone calls were made to the appropriate office at the municipal halls in the communities where each wetland was located. The zoning information for each site can be seen in the table below.

Table 4

\section{SITE ZONING CLASSIFICATION}

Wetland Name

1. Portsmouth High School

2. Portsmouth High School (Control)

3. Bradgate Associates

4. Bradgate Associates (Control)

5. Rockingham Mall

6. Rockingham Mall (Control)

7. Woonsocket Route 99

8. Woonsocket Route 99 (Control)

9. Arthur Nemon
Location

Portsmouth, NH

Portsmouth, NH

Nashua, NH

Nashua, NH

Salem, NH

Salem, NH

Lincoln, RI

Cumberland, RI

Saco, ME
Zoning

Class

SR2

SR2

R40

R 18

Com/Ind Residential

RA40

Not Avail

R1A 
10. Arthur Nemon (Control)

11. Signal/Resco Resource Recovery

12. Signal/Resco Resource (Control)

13. Cheshire WWTP

14. Cheshire WWTP (Control)

15. Robertson AP/Tomasso Nature Pk

16. Robertson AP/Tomasso (Control)

17. CT Route 7

18. CT Route 7 (Control)

19. Southbury Travel Center

20. Southbury Travel Center (Control)
Saco, ME

Millbury, MA

Millbury, MA

Cheshire, CT

Cheshire, CT

Plainville, CT

Plainville, CT

Norwalk, CT

Norwalk, CT

Southbury, CT

Southbury, CT
Industrial

I 2

Suburban Res

R40

R80

Industrial

Residential

R40

R40

B2E

B2E

Zoning information for one site could not be obtained. The site was the Woonsocket Route 99 control site. In this case, I chose to go with the current land use that I observed, as allowed by the $\underline{\mathrm{New}}$ Hampshire Method. Also, at the Robertson Airport/Tomasso Nature Park control site, the zoning classification given to me conflicted with the current land use at the site. As directed in the New Hampshire Method, I chose to go with the current land use classification that I observed.

\section{Data Calculations}

I next completed the calculations as described in the New Hampshire Method. I took the average of the functional value indexes (fvi) for each section: ecological integrity and wildlife habitat. I rounded them off to three points beyond the decimal. I then multiplied the fvi by the acreage of the wetland. Thus, in the $\underline{\mathrm{New}}$ Hampshire Method, the values given to the wetlands are influenced 
by the size of the wetland: the larger the wetland, the higher the fvi for that value of the wetland.

The final fvi's for both values were then added together to produce a final functional value index for the wetland. The calculations can be found on the field sheets for each site in Appendix A. These values can be used to compare the wetlands to each other. However, in this study, it is only equitable to compare the created wetlands to the control sites chosen for them. The values can be seen in the table below.

\section{Table 5}

\section{FUNCTIONAL VALUE INDEXES}

Wetland Name

1. Portsmouth High School

2. Portsmouth High School (Control)

3. Bradgate Associates

4. Bradgate Associates (Control)

5. Rockingham Mall

6. Rockingham Mall (Control)

7. Woonsocket Route 99

8. Woonsocket Route 99 (Control)

9. Arthur Nemon

10. Arthur Nemon (Control)

11. Signal/Resco Resource Recovery

12. Signal/Resco Resource (Control)

13. Cheshire WWTP

14. Cheshire WWTP (Control)
Size in

Type

Created $\quad 1.00$

Natural 1.25

1.152

1.874

Created

1.00

Natural

1.00

.761

1.509

Created $\quad 1.00$

.798

Natural

1.50

2.417

Created $\quad 3.50$

5.719

Natural

3.80

5.703

Restored $\quad .50$

Natural

.75

1.026

Created $\quad .50$

.515

Natural

1.00

1.624

Created

.85

1.005

Natural

1.00 
15. Robertson AP/Tomasso Nature Pk. Created $3.80 \quad 5.202$

16. Robertson AP/Tomasso (Control) Natural $4.50 \quad 6.940$

17. CT Route 7

Created $\quad 3.10$

3.428

18. CT Route 7 (Control)

Natural $\quad 3.00$

3.543

19. Southbury Travel Center Restored .65

20. Southbury Travel Center (Control) Natural 1.25

.642

1.710

As can be seen, in all but one comparison, the natural, or control site, has a higher fvi than the created or restored wetland. The Woonsocket Industrial Highway (Route 99) created site was the exception. In this comparison, the created wetland had a higher combined wildlife habitat/ecological integrity fvi than the natural wetland. However, as was mentioned above, the fvi's are influenced by size. Thus, in cases where the natural wetland was larger than the created/restored wetland, the fvi would naturally be higher. That occurred with eight of the ten created/restored wetlands. Since there is a difference in eight of the comparisons, it is necessary to recompute the fvi's to determine if the natural wetlands truly have a higher fvi than the created/restored wetlands.

The only point during the calculations that the size of the wetland can influence the fvi, is at the very end, where the fvi for each of the two values (ecological integrity, wildlife habitat) is multiplied by the acreage of the wetland. Up until this point the fvi's are not in any way influenced by the size of the wetlands. Thus, if both the created/restored and natural wetlands were multiplied by the same acreage, the results would be more representative of the 
true fvi's. This has been done and the results are shown in the table below:

Table 6

\section{RE-CALCULATED FUNCTIONAL VALUE INDEXES}

\section{Wetland Name}

1. Portsmouth High School

2. Portsmouth High School (Control)

5. Rockingham Mall

6. Rockingham Mall (Control)

7. Woonsocket Route 99

8. Woonsocket Route 99 (Control)

9. Arthur Nemon

10. Arthur Nemon (Control)

11. Signal/Resco Resource Recovery

12. Signal/Resco Resource (Control)

13. Cheshire WWTP

14. Cheshire WWTP (Control)
Type

Created $\quad 1.00$

Natural 1.00

Created $\quad 1.00$

Natural 1.00

Created $\quad 3.50$

Natural

3.50

Restored $\quad .50$

Natural $\quad .50$

Created $\quad .50$

Natural
Natural

Created

.50

.85

.85

3.80

3.80

Restored

.65

.65
FVI

1.499

5.719

5.254

.450

.683

.515

.812

1.005

.972

5.202

5.859

.642

.889

As can be seen by the table, the results have changed slightly. By assuming the wetlands are the same size and multiplying the fvi's of the two wetlands by the same acreage value, there is a decline in the final fvi of the control sites. 
When evaluating the difference it made in the comparisons, it can be seen that two of the created wetland sites now have a higher functional value index than their natural counterparts. These two created wetlands are the Cheshire Waste Water Treatment Plant and Woonsocket Route 99.

This study has shown that in 8 of the 10 comparisons made, the natural site was determined to have a better potential wildlife habitat than the created/restored site. Thus, only 20 percent of the created/restored sites were determined to be sufficient replacements for natural wetlands when considering wildlife habitat. 
Chapter Eight

\section{CONCLUSION}




\section{Chapter Eight}

\section{CONCLUSION}

It was the intention of this study to evaluate the hypothesis; human-made wetland replicas are not sufficient replacements for natural wetlands. An assessment of the potential wildlife habitat value of freshwater wetlands was performed. A comparison was used to determine if the potential wildlife habitat was better in created and restored wetlands or in natural wetlands. The tool used to evaluate the wildlife habitat value was the Method for the Comparative Evaluation of Nontidal Wetlands in New Hampshire. The results are listed in Chapter Seven, Data Analysis.

It was determined that the potential wildlife habitat in natural wetlands was superior to that of the created/restored wetlands. It was also indicated that eighty percent of the time, the created/restored wetlands are not sufficient replacements for natural wetlands. These results concurred with similar studies described in Chapter Four, Research Hypothesis.

Since the hypothesis was determined true, it indicates that wetland replications and restorations are not fulfilling their purpose. Creations and restorations are supposed to functionally replace the altered or destroyed natural wetland. If they cannot perform the functions of a natural wetland, then they are not sufficient replacements for them. 
Since these wetlands that are supposed to serve as mitigation for the destroyed natural wetlands are not functioning as well as the natural wetlands, then it is highly possible that wetlands are not being adequately protected. We are losing wetlands rather than preserving them. We are destroying them rather than replacing them. If this is the case, then there may be a problem with the mechanisms that are supposed to be protecting wetlands.

The protection of wetlands is piecemeal (Pontius, 1990: 12). Wetlands allegedly receive sufficient protection from the overlapping of federal, state, and local wetland protection efforts. However, if mitigation, the mechanism that is used by regulatory agencies to compensate for natural wetland loss, is not producing viable alternatives, then it can be suggested that the federal, state, and local protection efforts are not succeeding. Maybe protection specialists at all levels should re-evaluate the effectiveness of mitigation. There may be another alternative that will produce more promising results. Permit applicants usually propose to compensate for wetland losses by creating a wetland from an upland habitat or by enhancing existing wetland habitats (Thompson \& Williams-Dawe). This type of mitigation is attractive to developers, because it is just averaged into the cost of construction. It is also attractive to regulators because they feel they are succeeding in not allowing any further net loss of wetlands (Thompson \& Williams-Dawe). However, mitigation has several problems.

One of the main problems with wetland mitigation is the lack of monitoring. "There are no wetland police...The development industry knows that" (Stevens, 1991: pp. C9). Thus, the agencies 
that permit the mitigation as compensation, do not follow up to see if the artificial wetland is successful. In addition, it appears that those that are creating the wetlands, know nothing about wetland creation/restoration. "...As federal and state governments belatedly require developers and farmers to compensate for or "mitigate" any loss of wetlands they cause, inexpert, inexperienced, often less competent practitioners are rushing into the field" (Stevens, 1991: pp. C1). Some believe that wetlands cannot be created. "Based upon the limited studies of both intentional and unintentional restoration and creation projects to date, there is a general scientific consensus that no wetland can be duplicated or replicated exactly" (Kusler, 87: 3). Yet others believe that wetlands can be created, though they do not know how long it takes to create one. "No one can be positive how long it takes to establish artificial wetlands, much less how to judge a level of success sufficient to justify the avoidable destruction of natural habitats" (Thompson \& Williams-Dawe).

Many of created, enhanced, or restored wetlands have been reported as successes. However, most are not really successes upon close inspection. It seems that the criteria used to evaluate success in many cases was simply whether wetland plants had established themselves on the site (Larson, 1987).

However, it is reported that some functions of wetlands can be created. "There appears to be a consensus among scientists and observers that certain types of wetland wildlife habitat -- primarily waterfowl and marsh bird habitat -- can be created in upland areas where the right combinations of topography and water supply are present" (COEQ, 1988: 2). 
Thus, there is agreement that there are problems with wetland mitigation. If wetland mitigation is to continue, the regulatory agencies should focus more clearly on avoidance and minimization and less on compensation as an alternative. Care should also be taken to permanently preserve those wetlands that are particularly valuable to society. If there are no alternatives and wetland mitigation is the only solution, then the applicants should be required to do a study of the existing values of the wetland they are destroying (as the EPA and COE require under Section 404). They should then be responsible to create a wetland that serves those same functions. If wetlands are allowed to be restored and created, a monitoring program should be an necessary aspect of the mitigation plan. Someone should also be appointed to maintain the new wetland site. The cost of a wetland creation or restoration should not be allowed to dictate the kind of wetland created or restored. Should something go wrong in the creation/restoration attempt, there should be provisions for new action to be taken, (COEQ, 1988).

Whatever the future course of wetland protection is, it is expected that planning will take a larger role in mitigation strategies. "Under programs now under way by federal agencies, wetlands considered unsuitable for development will be better mapped, enabling planners to steer projects away from problematic areas" (Krohe, 1989: 9).

In conclusion, wetlands should be regulated not as plant communities, but rather as intricate ecosystems that provide functions for the benefit of society (Larson, 1987). Also, it is 
important to keep in mind that, "The easiest kind of wetlands damage to mitigate,...is the damage that isn't allowed in the first place” (Krohe, 1989: 9) 


\section{APPENDICIES}


Appendix A

\section{FIELD SHEETS}




\section{SUMMARY SHEET FOR THE N.H. METHOD Ullow mash creitior.}

wetland name or code Portsmouth thigh School_total area of wetland I lace county Rockingham town Bortsmowth, NH Dare August 10, 1991 investigator(s) Staci Holcormbe, Dand Hulseberg

\begin{tabular}{|c|c|c|c|}
\hline $\begin{array}{c}A \\
\text { Functlonal } \\
\text { Value }\end{array}$ & $\begin{array}{c}\text { B } \\
\text { FVI From } \\
\text { Data Sheots }\end{array}$ & $\begin{array}{c}\text { C } \\
\text { Slze of Evaluation } \\
\text { Area (Acres) }\end{array}$ & $\begin{array}{c}D \\
\text { Wetland Value Units } \\
8 \times C\end{array}$ \\
\hline 1. Ecological Integrity & WOWE. 538 & 1 & 100018.558 \\
\hline 2. Wildlife Habitat & .614 & 1 & .614 \\
\hline $\begin{array}{l}\text { 3. Finfish Habitat: } \\
\text { Part A - Rivers and Streams }\end{array}$ & & & 1.152 \\
\hline Part $B$ - Ponds and Lakes & & & \\
\hline
\end{tabular}

4. Educational Potential

5. Visuallaesthetic Quality

6. Water Based Recreation

7. Flood Control Potential

8. Ground Water Use Potential

9. Sediment Trapping

10. Nutrient Attenuation

11. Shoreline Anchoring and

Dissipation of Erosive Forces

12. Urban Quality of Life

8: Wildlife Habitat

C: Educational Opportunity

D: VisuaVAesthetic Quality

$E$ : Water Based Recreation

13. Historical Site Potential

14. Noteworthiness 
- SCS soils map

- N.H. Water Quality Report 10 Congress 305(b)

- USGS topographic map or recent aerial pholograph

- A method to calculate area (Dot grid, planimeter, etc.)

- Ruler or scale

- Map wheel (Optional)

\begin{tabular}{|c|c|c|c|}
\hline $\begin{array}{c}\text { A } \\
\text { Evaluation } \\
\text { Questions }\end{array}$ & $\begin{array}{c}\text { B } \\
\text { Computations } \\
\text { or Actual Value }\end{array}$ & $\begin{array}{c}\mathrm{C} \\
\text { Evaluation } \\
\text { Criteria }\end{array}$ & $\begin{array}{c}D \\
\text { Functior: }{ }^{\prime} \text { Vah } \\
\text { index }=y^{\prime}\end{array}$ \\
\hline
\end{tabular}

\section{QUESTIONS TO ANSWER IN THE OFFICE:}

1. Percent of wetland having very poorly drained soils or Hydric A soils and/or open water.

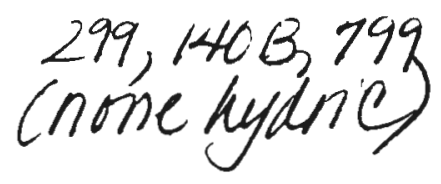

2. Dominant land use zoning of wetland (see town zoning map). Use current land use if different from what is zoned.
a. More than 50 percent
h. From 25 to 50 percent
c. Less than 25 percent
$1:$
$0 \vdots$
$0 .:$

a. Agriculture, forestry, or 1.0 similar open space zoning

b. Rural residential $\quad 0.5$

c. CommerciaVindustrial, $\quad 0.1$ high density residential

\section{QUESTIONS TO ANSWER IN THE FIELD:}

3. Water quality of the watercourse, pond, or lake associated with the wetland.

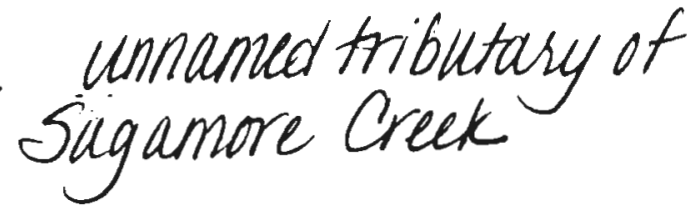

4. Ratio of the number of occupied buildings within 500 feet of the wetland edge to the total area of the wetland (acres).
a. High: Minimal pollution. $\quad 1.0$ Actual water quality meets or exceeds Class A or B standards
b. Medium: Moderate pollu- tion. Actual water quality is below Class 8 stan- dards

a. Less than 1 bldg: 10 acres $(<0.10)$

b. From 1 bldg: 10 acres to 1 bldg: 2 acres $(0.10$. $0.50)$

c. More than 1 bldg: 2 acres (>0.5)

c. More than 50 percent filled for the ball tilld

More than 80 percent
b. From 20 to 80 percent
c. Less than 20 percent 500 feet in width. woodland glote
depth to this can see the wettand ts berng
used for educational purposes.
periohery is trodden

a. Low level: Few trails in

\section{WITHIN WETLAND as evi-}

Level of human activity denced by litter, bike trails, roads, residences, etc.

\section{use and/or sparse litter} used trails, roads, etc.

c. High level: Many trails, roads, etc. within wetland b. Moderate level: Some 


\begin{tabular}{cccc}
\hline A & B & C & D \\
Evaluation & Computations & Evaluation & Functional Vai \\
Questions & or Actual Value & Criteria & Index (FVI) \\
\hline
\end{tabular}

QUESTIONS TO ANSWER IN THE FIELD (continued):

8. Level of human activity IN UPLAND within 500 leet of the wetland edge as evi denced by litter, bike trails, roads, residences, etc.

9. Percent of wetland plant community presently being altered by mowing, grazing, farming, or other activity. (Include areas now dominated by phragmites or purple bosestrite).

10. Percent of wetland actively being drained for agriculture or other purposes.

11. Number of public road andror railroad crossings per 500 feet of wetland (measured along long axis of wetland).

12. Long-term stability.

$$
\begin{aligned}
& \text { wettand partially } \\
& \text { dependent on dike, though its } \\
& \text { cow elevation }+ \text { being at base of } \\
& \text { steep hill woudd drect nundf } \\
& \text { toward the site }
\end{aligned}
$$

none could be$$
\text { detected }
$$

none are paralele ot adjacent.. a. Low level: Few trails in use $\quad 1.0$ andror sparse litter

b. Moderate level: Some trails, $\quad 0.5$ scattered residences, etc.

c. High level: Many trails, roads, etc. within upland

a. Less than 10 percent

b. From 10 to 50 percent

c. More than 50 percent

0.5

AVERAGE FVI FOR FUNCTIONAL VALUE $1=$ Average of column D = EVALUATION AREA FOR FUNCTIONAL VALUE 1 = Total area of wetland $.5375 \div(6.45 \div 12)$

a. Wetland appears to be naturally occurring, not impounded by dam or dike

b. Wetland appears 10 be somewhat dependent on artificial diking by dam. road, fill, etc.
10

0.5

0.1

1.0 acres. 


\section{NEEDED FOR THIS EVALUATION:}

- USGS topographic map

- Land use map and/or recomt aerial pholographs

- Ruler or scale

- A method to calculate area (Dol grid, planimeter, etc.)

- N.H. Water Quality Report to Congress 305(b)
A

Evaluation

Questions
B

Computations

or Actual Value
Evaluation

Criteria
Functional Valu

Index (FVI)

\section{QUESTIONS TO ANSWER IN THE OFFICE:}

1. Ecological integrity.

Average FVI irom Functional Value $1 \cdot . \underline{5 j}$

2. Area of shallow permanent open water (less than 6 feet deep) including streams

in or adjacent to wetland.

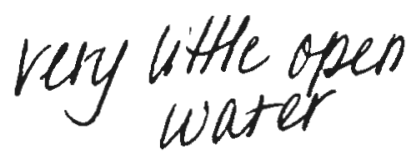

a. More than 3 acres

1.0

b. From 0.5 to 3 acres

0.5

Less than 0.5 acre

0.1

\section{QUESTIONS TO ANSWER IN THE FIELD:}

3. Water quality of the watercourse,

FVI from Question V.1.3

lake, or pond associated with the

wetland.

4. Wetland diversity.

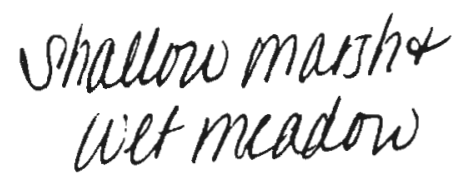

wiet meadow
a. Three or more wetland classes
9.0 present
(b) Two wetland classes present
c. One wetland class present
0.5

a. Emergent marsh and/or shallow $\quad 1.0$ open water

b. Forested and/or scrub-shrub wetland 0.5

c. Scrub-shrub saturated (bog) or 0.1 wet meadow

a. At least two wetland classes highly 1.0 interspersed. Areas of each class scattered within wetland like a patchwork quilt

some nitung in
mitig ation trea b. Moderate interspersion of welland 0.5 classes

c. Low degree of interspersion. Each 0.1 wetland class is more or less contiguous and separate from the other classes 


\begin{tabular}{cccc}
\hline A & Bvaluation & $C$ & D \\
Questions & Computations & Evaluation & Functional Value \\
Or Actual Value & Criteria & Index) \\
\hline
\end{tabular}

7. Welland juxtaposition.

8. Number of islands or inclusions of upland within wetland.

9. Wildlife access to other wellands (overland). Travel lanes should be 50-100 feet wide.

10. Percent of welland edge bordered by upland witdite habitat (brush, woodland, active farmland, or idle land) at least 500 feet in width.

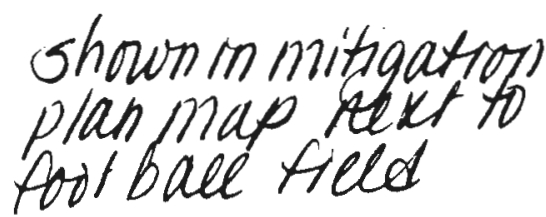

plan map feet to foot bale tield a. wetlands within a 1 mile radius by perennial stream or lake

b. Wetland connected to other wetlands within a 1 to 3 mile radius by perennial stream or lake, OR other unconnected wetlands are present within a 1 mile radius

c. Wetland not hydrologically connected to other wetlands within 3 miles and no other unconnected wellands within 1 mile

a. Two or more

b. One

None

a. Free access along well vegetated stream comidor. woodland, or lakeshore

b. Access partially blocked by roads, urban areas, or other obstructions

c. Access blocked by roads. urban areas, or other obstruc. tions

2. More than 40 percent
1.0 photos, at site isita on us 65 topo r hap 


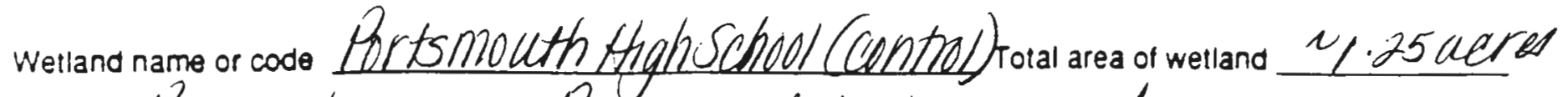

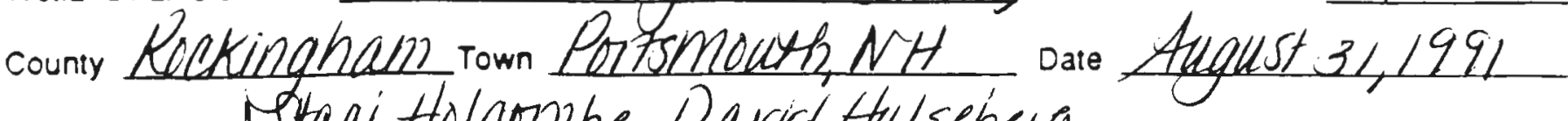

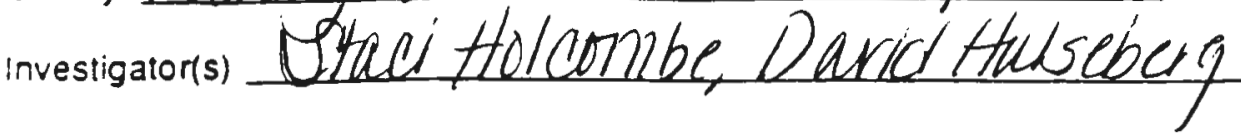

\begin{tabular}{|c|c|c|c|}
\hline $\begin{array}{c}\text { A } \\
\text { Functlonal } \\
\text { Value }\end{array}$ & $\begin{array}{c}\text { B } \\
\text { FVI From } \\
\text { Data Sheots }\end{array}$ & $\begin{array}{c}\text { C } \\
\text { Size of Evaluation } \\
\text { Area (Acres) }\end{array}$ & $\begin{array}{c}D \\
\text { Wetland Value Untts } \\
B \times C\end{array}$ \\
\hline 1. Ecological Integrity & $8 \theta_{k}$ & 1.25 & .005 \\
\hline 2. Wildlife Habitat & .695 & 1.25 & .869 \\
\hline $\begin{array}{l}\text { 3. Finfish Habitat: } \\
\text { Pan A - Rivers and Streams }\end{array}$ & & & otal dilgidit \\
\hline Part $B$ - Ponds and Lakes & & & 1.0 \\
\hline
\end{tabular}

\section{Educational Potential}

5. VisuaVAesthetic Quality

\section{Water Based Recreation}

7. Flood Control Potential

\section{Ground Water Use Potential}

\section{Sediment Trapping}

10. Nutrient Attenuation

11. Shoreline Anchoring and

Dissipation of Erosive Forces

12. Urban Quality of Life

B: Wildife Habitat

C: Educational Opportunity

$D$ : VisuaVAesthetic Quality

E: Water Based Recreation

\section{Historical Site Potential}

14. Noteworthiness 
(witi has succuded to serul shrub)

NEEDED FOR THIS EVALUATION:

- Zoning map

- SCS soils map

- N.H. Water Quality Report to Congress 305(b)

- USGS topographic map or recent aerial photograph

- A method to calculate area (Dot grid, planimeter, etc.)

- Ruler or scale

- Map wheel (Optional)

\section{A}

Evaluation

Questions
Computations

or Actual Value
Postsinatio H. 5. (control)

Functional Value 1 ECOLOGICAL INTEGRITY

\section{QUESTIONS TO ANSWER IN THE OFFICE:}

1. Percent of wetland having very poorly drained soils or Hydric A soils and/or open water.

2. Dominant land use zoning of wetland (see town zoning map). Use current land use if ditferent from what is zoned.

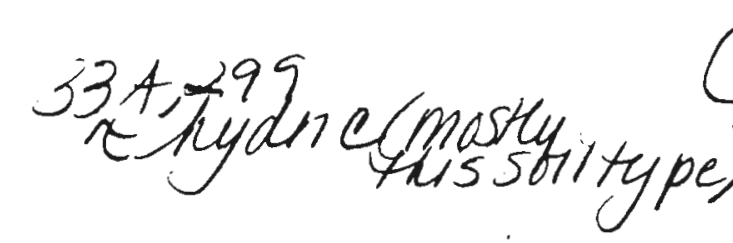

\begin{tabular}{ll}
\multicolumn{1}{c}{ Criteria } & Index (FVI) \\
\hline & \\
a. More than 50 percent & 1.0 \\
b. From 25 to 50 percent & 0.5 \\
c. Less than 25 percent & 0.1 \\
& \\
a. Agriculture, forestry, or & 1.0 \\
similar open space & \\
zoning & \\
Rural residential & 0.5 \\
C.- CommerciaVindustrial, & 0.1 \\
high density residential &
\end{tabular}

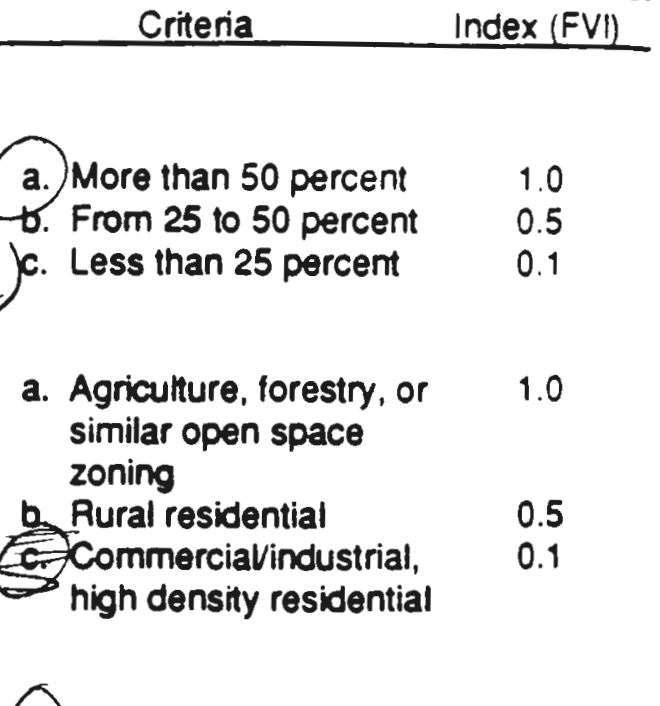

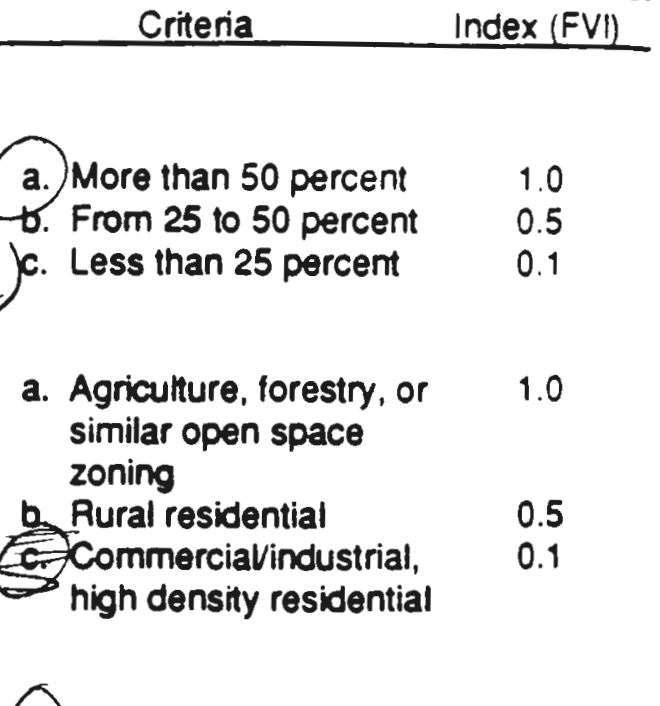

\section{QUESTIONS TO ANSWER IN THE FIELD:}

SR2-xingle fanuly

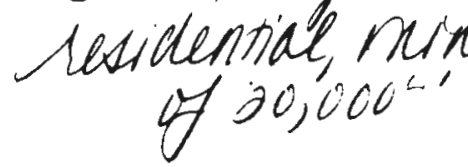

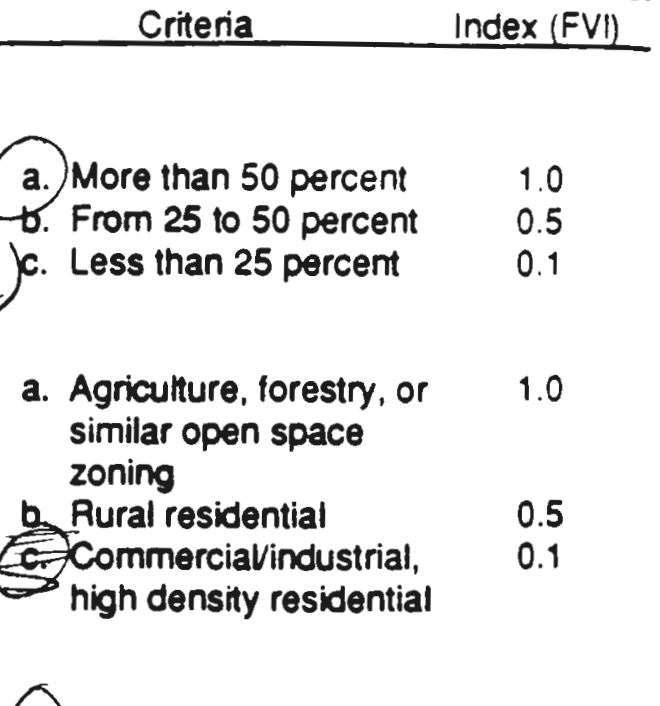

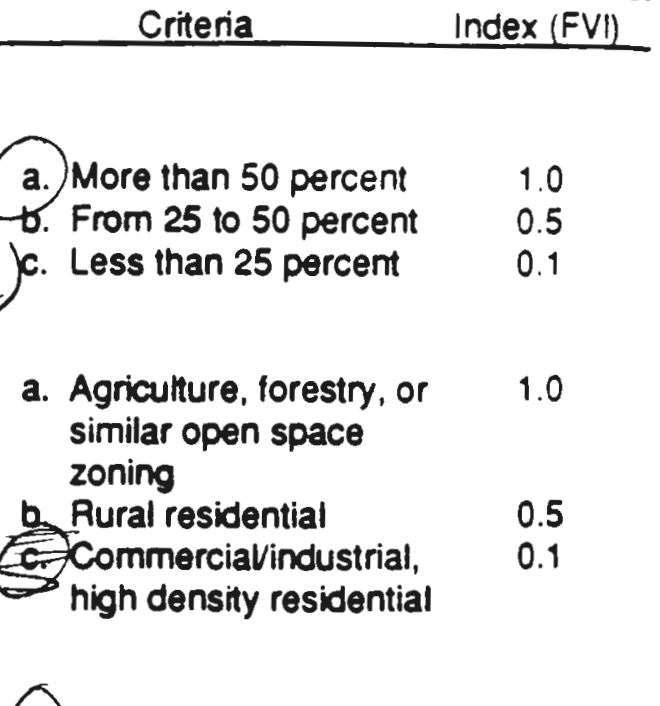

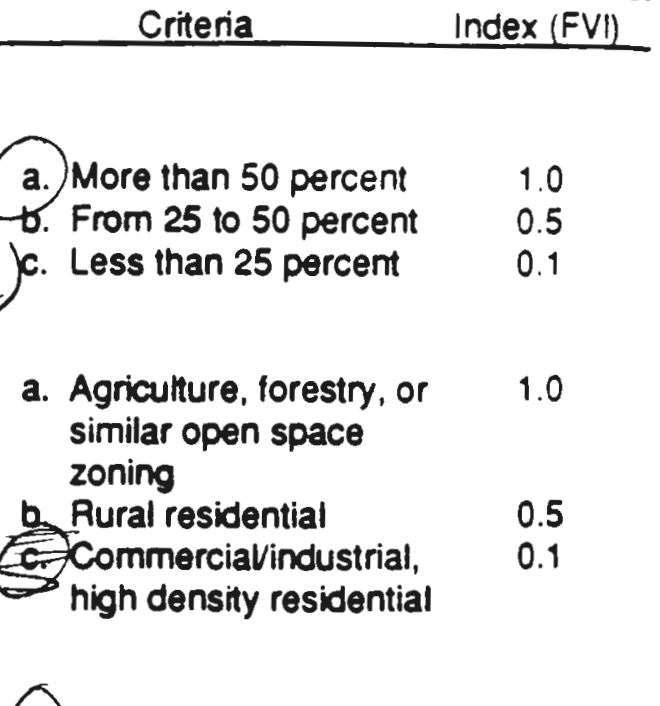

\begin{tabular}{ll} 
Criteria & Index (FVI) \\
\hline & \\
a. More than 50 percent & 1.0 \\
b. From 251050 percent & 0.5 \\
c. Less than 25 percent & 0.1 \\
& \\
a. Agriculture, forestry, or \\
similar open space \\
zoning \\
Rural residential \\
CommerciaVindustrial, \\
Com high density residential \\
\end{tabular}

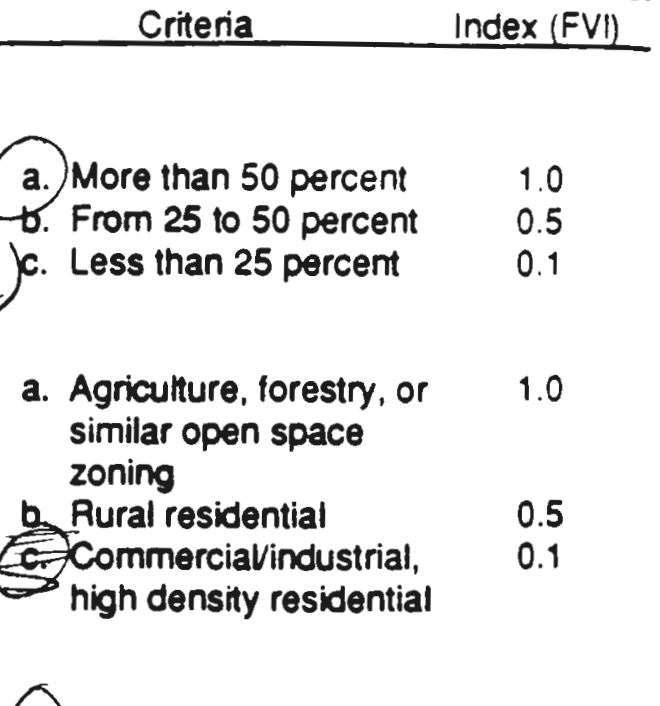

3. Water quality of the watercourse, pond, or lake associated with the wetland.

a. High: Minimal pollution. $\quad 1.0$ Actual water quality meets or exceeds Class A or $\mathbf{B}$ standards

b. Medium: Moderate pollution. Actual water quality is below Class B standards

4. Ratio of the number of occupied buildings within 500 feet of the wetland edge to the total area of the wetland (acres).

5. Percent of original wetland filled.

6. Percent of wetland edge bordered by a butfer of woodland or idle land at least 500 feet in width.

7. Level of human activity WITHIN WETLAND as evidenced by litter, bike trails, roads, residences, etc.

\section{N 3 kuildings: 21.25 ac}

a. Less than 1 bldg: 10 acres $(<0.10)$

b. From 1 bldg: 10 acres to 1 bldg: 2 acres (0.100.50 )

c. More than 1 bidg: 2 acres (>0.5)

a. Less than 10 percem

b. From 10 to 50 percem

c. More than 50 percent

(a. More than 80 percent

b. From 20 to 80 percent

c. Less than 20 percent

1.0

0.5

0.1

a. Low level: Fow trails in 1.0 use and/or sparse litter

b. Moderate level: Some used trails, roads, etc.

c. High level: Many trails, roads, etc. Within wetland 


\begin{tabular}{cccc}
\hline A & $\mathbf{B}$ & C & 0 \\
$\begin{array}{c}\text { Evaluation } \\
\text { Questions }\end{array}$ & $\begin{array}{c}\text { Computations } \\
\text { or Actual Value }\end{array}$ & $\begin{array}{c}\text { Evaluation } \\
\text { Criteria }\end{array}$ & $\begin{array}{c}\text { Functional Val } \\
\text { Index (FVI) }\end{array}$ \\
\hline
\end{tabular}

OUESTIONS TO ANSWER IN THE FIELD (continuod):

8. Level of human activity IN UPLANO within 500 feet of the wetland edge as evi denced by litter, bike trails, roads, residences, etc.

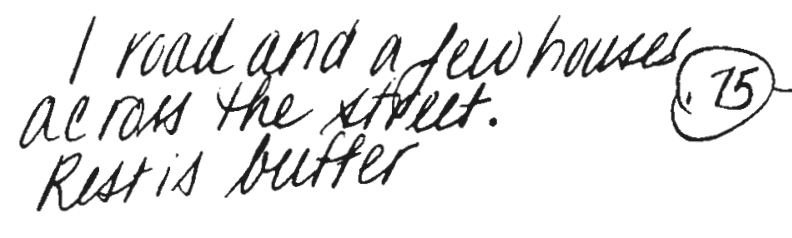

a. Low level: Few trails in use 1.0 and/or sparse litter

b. Moderate level: Some trails, $\quad 0.5$ scattered residences, etc.

c. High level: Many trails, roads, etc. within upland

a. Less than 10 percent $\quad 1.0$

6. From 10 to 50 percent 0.5

c. More than 50 percent 0.1

9. Percent of wetland plant community presently being attered by mowing, grazing, farming, or other activity. (Include areas now dominated by phragmites or purple loosestrife).

10. Percent of wetland actively being drained for agriculture or other purposes.

a. Less than 10 percent 1.0

b. From 10 to 50 percent 05

c. More than 50 percent 0.1

11. Number of public road and/or railroad crossings per 500 feet of welland (measured along long axis of wetland).

b. Wetland appears to be somewhat dependent on antificial diking by dam. road, fill, etc.

AVERAGE FVI FOR FUNCTIONAL VALUE $1=$ Average of column D = $14+4.19$

EVALUATION AREA FOR FUNCTIONAL VALUE 1 = Total area of wetland $=1.25$ acres. 


\section{NEEDED FOR THIS EVALUATION:}

- USGS topographic map

- Land use map and/or recent aerial photographs

- Puler or scale

- A method to calculate area (Dot grid, planimeter, etc.)

- N.H. Water Quality Report 10 Congress 305(b)

\section{A}

Evaluation

Questions
Computations or Actual Value

\section{Evaluation \\ Criteria}

Function: $\vee$ all Index $=:$ : 1

\section{QUESTIONS TO ANSWER IN THE OFFICE:}

1. Ecological integrity.

2. Area of shallow permanent open water (less than 6 feet deep) including streams

in or adjacent to wetland.
Average FVI from Functional Value 1
a. More than 3 acres
b. From 0.5 to 3 acres
c. Less than 0.5 acre

1.2

05

0 :

3. Water quality of the watercourse,

FVI from Question V.1.3 lake, or pond associated with the welland.

4. Welland diversity.

$$
\begin{aligned}
& \text { Eu has suceuded toss. } \\
& \text { some Fo there too }
\end{aligned}
$$

a. Three or more wetland classes present

b. Two wetland classes present

c. One wetland class present

5. Dominant wetland class.

a. Emergent marsh and/or shallow open water

6.) Forested and/or scrub-shrub wetland

0.5

c. Scrub-shrub saturated (bog) or wet meadow

6. Interspersion of vegetation classes andjor open water.

a. At least two wetland classes highly interspersed. Areas of each class scattered within wetland like a patchwork quilt

b. Moderate interspersion of wetland classes

c. Low degree of interspersion. Each welland class is more or less coniguous and separate from the other classes 


\begin{tabular}{cccc} 
A & B & $C$ & 0 \\
Evaluation & Computations & Evaluation \\
Questions & Or Actual Value & Criteria & Index (FVI) \\
\hline
\end{tabular}

\section{Wetland juxtaposition.}

8. Number of islands or inclusions of upland within wetland.

9. Wildlife access to other wetlands (overland). Travel lanes should be 50-100 feet wide.

\section{hilly terrain}

10. Percent of wetland edge bordered by upland wildile habitat (brush, woodland, active farmland, or idle land) at least 500 feet in width. a. Wetland connected 10 other 1.0 wetlands within a 1 mile radius by perennial stream or lake

b. Wetland connected to other wetlands within a 1 to 3 mile radius by perennial stream or lake, OR other unconnected wetlañds arepresent within a 1 mile radius

c. Wetland not hydrologically connected to other wellands within 3 miles and no other unconnected wetlands within 1 mile
(a. Two or more
1.0
b. One
0.5
c. None
0.1
a. Free access along well vegetated stream corridor, woodland, or lakeshore
b. Access partially blocked by roads, urban areas, or other obstructions
c. Access blocked by roads, urban areas, or other obstruc- tions

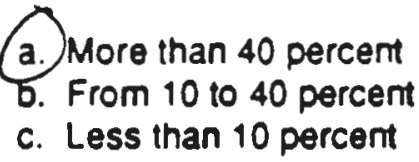

AVERAGE FVI FOR FUNCTIONAL VALUE $2=$ Average of column D $=.695 .(6.946 \div 10)$ EVALUATION AREA FOR FUNCTIONAL VALUE 2 - Total area of wetland $=1.25$ acres. 
SUMMARY SHEET FOR THE N.H. METHOD

weland ane or coose Bradgate Asicciates

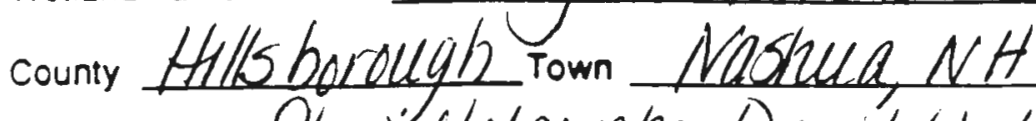
inversianorss Stheri Holcombe, Davió Hulseberg

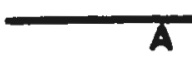

Functlonal

Value

1. Ecological Integrity

2. Wildife Habitat

3. Fintish Habitat:

Pant A - Rivers and Streams

Part B - Ponds and Lakes

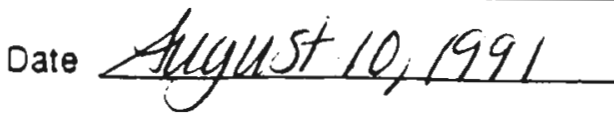

Total area of wetland $\mathrm{N} / \mathrm{ACr}$

4. Educational Potential

5. VisuaVAesthetic Quality

6. Water Based Recreation

7. Flood Comtrol Potential

8. Ground Water Use Potential

9. Sediment Trapping

10. Nutrient Attenuation

11. Shoreline Anchoring and

Dissipation of Erosive Forces

12. Urian Quality of Life

B: Wildlite Habitat

C: Educational Opportunity

D: VisuaVAesthetic Quality

E: Water Based Recreation

13. Historical Site Potential
FVI From

Data Sheots

.392

.369
Size of Evaluation

Area (Acres)
D

Wetland Value Units

$B \times C$
.392

1

.369

total

.761 
NEEDED FOR THIS EVALUATION:

- Zoning mã̄

- SCS soils map

- N.H. Water Quality Report to Congress 305(b)

- USGS topographic map or recent aerial photograph

- A method to calculate area (Dot grid, planimeter, etc.)

- Ruler or scale

- Map wheel (Optional)

A

Evaluation

Questions biallgate Assound
B

Computations

or Actual Value
Evaluation

Criteria
Functional Valut Index (FVI)

\section{QUESTIONS TO ANSWER IN THE OFFICE:}

1. Percent of wetland having very poorly drained soils or Hydric A soils andlor open water.

2. Dominant land use zoning of wetland (see lown zoning map). Use current land use if different from what is zoned.

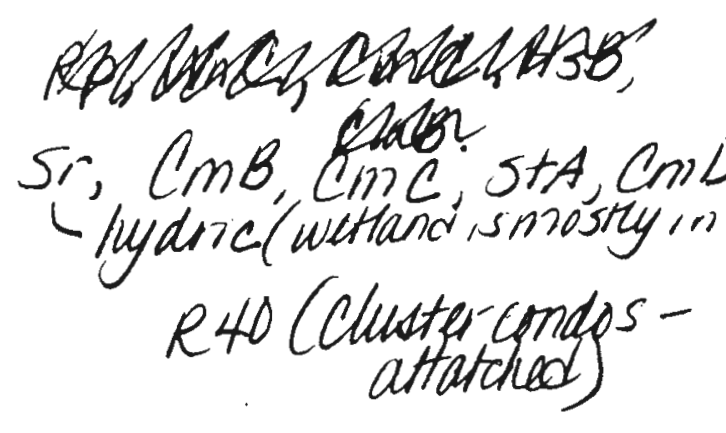

a. More than 50 percent

b. From 25 to 50 percent

c. Less than 25 percent
1.0

0.5

0.1

a. Agriculture, forestry, or similar open space zoning

b. Rural residential

c.) CommerciaVindustrial, high density residential

\section{QUESTIONS TO ANSWER IN THE FIELD:}

3. Water quality of the watercourse, pond, or lake associated with the wetland.

4. Ratio of the number of occupied buildings within 500 feet of the wetland edge to the total area of the wetland (acres).

5. Percent of original wetland filled.

6. Percent of welland edge bordered by a butfer of woodland or idle land at least 500 feet in width.

7. Level of human activity WITHIN WETLAND as evidenced by litter, bike trails. roads, residences, etc.

Continued on next page..

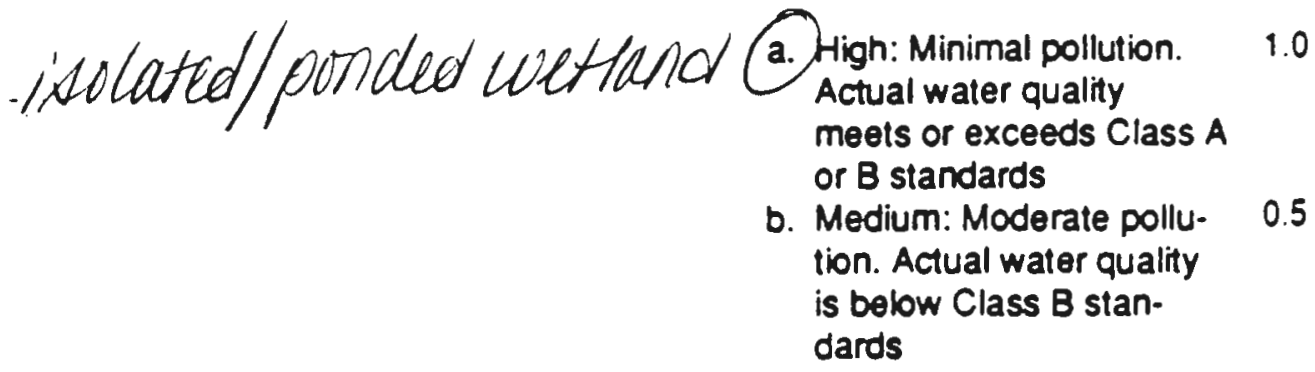

d/O burdings: lace

a. Less than 1 bidg: 10 acres $(<0.10)$

b. From 1 bldg: 10 acres 10 1 bldg: 2 acres 10.10 . 0.50)

c. More than 1 bldg: 2 acres $(>0.5\rangle$

a. Less than 10 percent b. From 10 to 50 percent c. More than 50 percent

a. More than 80 percent none at wel bordenng.
some on atter travg
the road. tome trash endert reiderices adjacent. b. From 20 to 80 percent c. Less than 20 percent

a. Low level: Fow trails in use andyor sparse litter

b. Moderate level: Some used trails, roads, etc.

c. High level: Many trails, roads, etc. within welland 


$\begin{array}{cc}A & B \\ \text { Evaluation } & \text { Computations } \\ \text { Questions } & \text { or Actual Value }\end{array}$

\section{QUESTIONS TO ANSWER IN THE FIELD (continued):}

8. Level of human activity IN UPLANO within 500 feet of the wetland edge as evi denced by litter, bike trails, roads, residences, etc.

9. Percent of wetland plamt community presently being attered by mowing, grazing. farming, or other activity. (Include areas now dominated by phragmites or purple bosestrife).

10. Percent of welland actively being drained for agriculture or other purposes.

11. Number of public road and/or railroad crossings per 500 leet of wetland (measured along long axis of wetland). a. Low level: Few trails in use $\quad 1.0$ and/or sparse litter

b. Moderate level: Some trails, 0.5 scattered residences, elc.

c. High level: Many trails, roads, etc. within upland

a. Less than 10 percent

b. From 10 to 50 percent

12. Long-term stability.

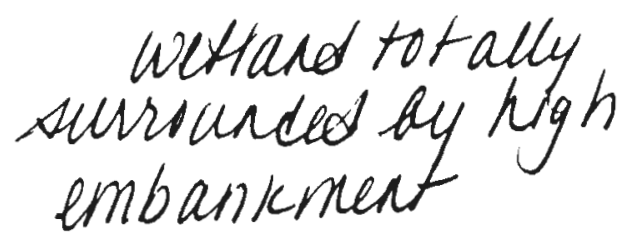

a. Less inan 10 percent 10

b. From 10 to 50 percent 05

c. More than 50 percent 0.1
2 roads purallel to cong axis sy wettand a. None

b. One or fewer

(c.) Two or more

a. Welland appears to be naturally occurring, not impounded by dam or dike

b. Wetland appears to be somewhat dependent on artificial diking by dam. road, fill, etc. 


\section{NEEDED FOR THIS EVALUATION:}

- USGS topographic map

- Land use map and/or recent aerial photographs

- Ruler or scalo

- A method to calculate area (Dot grid. planimeter, etc.)

- N.H. Water Quality Report to Congress 305(b)
Brallgate Asscarles

Functional Value 2

\begin{tabular}{cccc}
\hline $\mathbf{A}$ & $\mathbf{B}$ & $\mathrm{C}$ & $\mathrm{D}$ \\
$\begin{array}{c}\text { Evaluation } \\
\text { Questions }\end{array}$ & $\begin{array}{c}\text { Computations } \\
\text { or Actual Value }\end{array}$ & $\begin{array}{c}\text { Evaluation } \\
\text { Criteria }\end{array}$ & $\begin{array}{c}\text { Functional Valk } \\
\text { Index IFVII }\end{array}$ \\
\hline
\end{tabular}

\section{QUESTIONS TO ANSWER IN THE OFFICE:}

1. Ecological integrity.

Average FVI from Functional Value $1 . \underline{392}$

2. Area of shallow permanent open water (less than 6 feet deep) including streams in or adjacent to wetland.

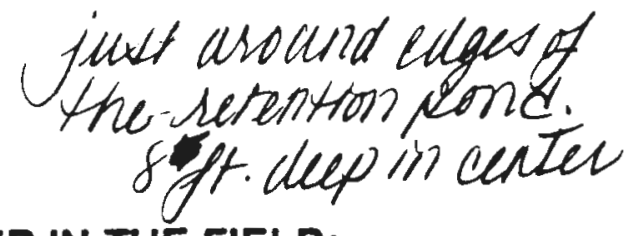

\section{QUESTIONS TO ANSWER IN THE FIELD:}

3. Water quality of the watercourse, lake, or pond associated with the wetland.

4. Welland diversity.

$$
\begin{aligned}
& \text { if the tite were not being } \\
& \text { nowed, then thallow marsh } \\
& \text { chol open water would be the } \\
& \text { 5. Dominant wetland class. } \\
& \text { dominailt class }
\end{aligned}
$$

6. Interspersion of vegetation classes and/or open water.
a. More than 3 acres
b. From 0.5 to 3 acres
c. Dess than 0.5 acre
1.0
0.5
0.1

a. Three or more welland classes $\quad 9.0$ present

b. Two wetland classes present

c. One wetland class present

0.5

0.9 (a.) Emergent marsh andvor shallow $\quad 90$
open water

b. Forested and/or scrub-shrub wetland

c. Scrub-shnub saturated (bog) or wet meadow

0.5

0.1

1.0

a. At least two wetland classes highly interspersed. Areas of each class scattered within welland like a patchwork quith

b. Moderate interspersion of wetland classes

c. Low degree of interspersion. Each wetland class is more or less contiguous and separate from the other classes 


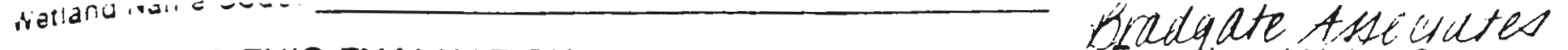

NEEDED FOR THIS EVALUATION:

Fungtional value 2

WETLAND WILDLIFE HABITAT

(cominued)

\begin{tabular}{cccc}
\hline A & Evaluation & $\mathbf{C}$ & \\
Questions & $\begin{array}{c}\text { Computations } \\
\text { or Actual Value }\end{array}$ & $\begin{array}{c}\text { Evaluation } \\
\text { Criteria }\end{array}$ & $\begin{array}{c}\text { Functional Value } \\
\text { Index (FVI) }\end{array}$ \\
\hline
\end{tabular}

7. Welland juxtaposition.

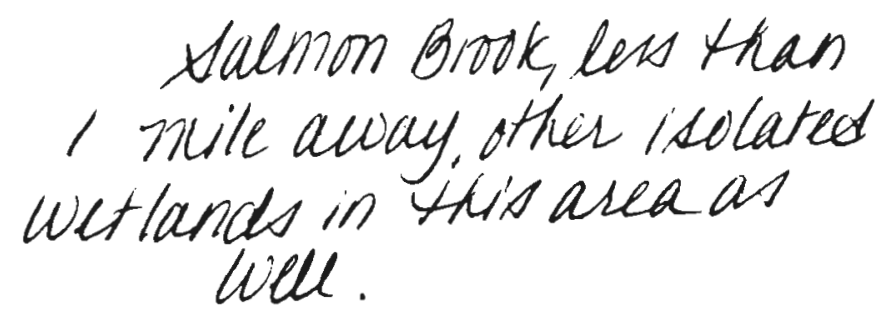

8. Number of islands or inclu. sions of upland within wetland.

a. Wetland connected to other 1.0 wetlands within a 1 mile radius by perennial stream or lake

b. Wetland connected to other wetiands within a 1 to 3 mile radius by perennial stream or lake, OR other unconnected wetlands are present within a 1 mile radius

c. Wetland not hydrologically connected to other wetlands within 3 miles and no other unconnected wetlands within 1 mile

$\begin{array}{ll}\text { a. Two or more } & 1.0 \\ \text { b. One } & 0.5 \\ \text { c. None } & 0.1\end{array}$

9. Wildlife access to other wetlands (overland). Travel lanes should be 50-100 feet wide.
a. Free access along well vegetated stream comidor. woodland, or lakeshore
b. Access partially blocked by roads, urban areas, or other obstructions
c. Access blocked by roads, urban areas, or other obstruc. tions

(10)


SUMMARY SHEET FOR THE N.H. METHOD

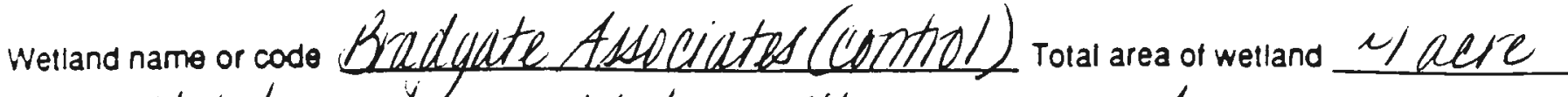

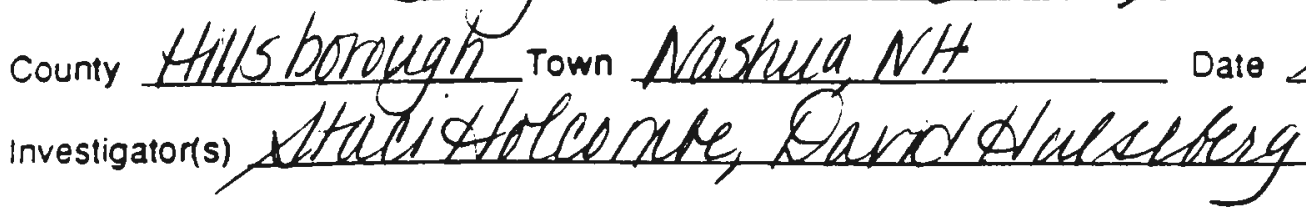

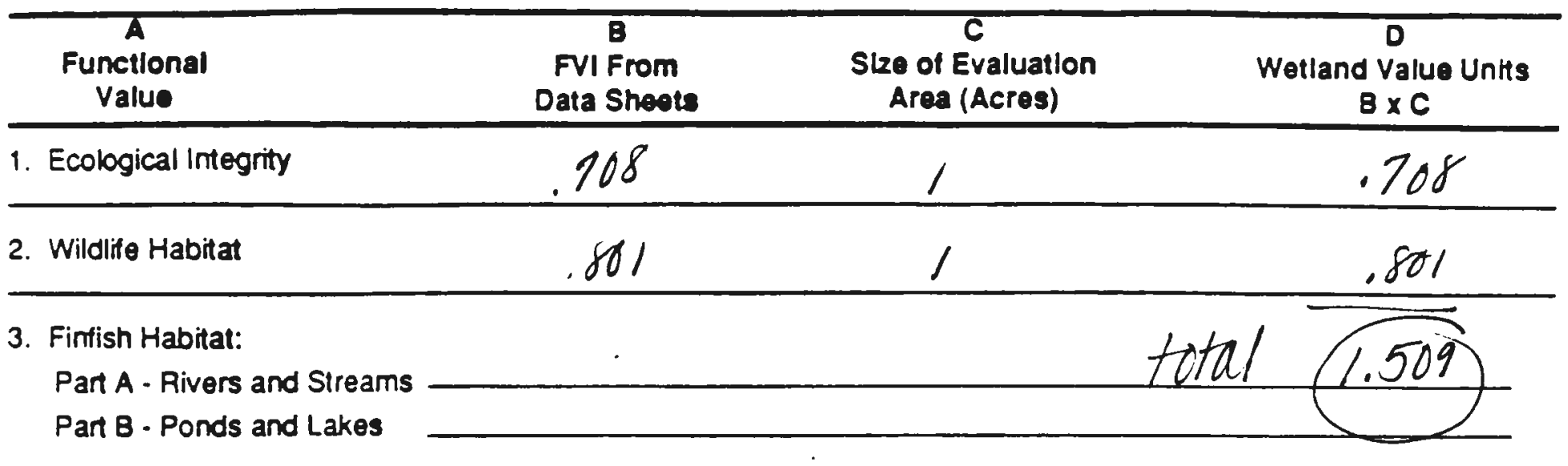

4. Educational Potential

5. VisuaVAesthetic Quality

6. Water Based Recreation

7. Flood Control Potential

8. Ground Water Use Potential

9. Sediment Trapping

10. Nutriem Attenuation

11. Shoreline Anchoring and

Dissipation of Erosive Forces

12. Urban Quality of Life

B: Wikdife Habitat

C: Educational Opportunity

$D$ : VisuaVAesthetic Ouality

$E$ : Water Based Recreation

13. Historical Site Potemtial

14. Noteworthiness 
NEEDED FOR THIS EVALUATION:

- Zoning mâ

- SCS soils map

- N.H. Water Quality Report to Congress 305(b)

- USGS topographic map or recent aerial photograph

- A method to calculate area (Dol grid, planimeter, elc.)

- Ruler or scale

- Map wheel (Optional)
A

Evaluation

Questions
Bradaate tsucuates (control).

Functional Value 1

\section{ECOLOGICAL INTEGRITY}

Computations
or Actual Value
Evaluation

Criteria
Functional Vah Index (FVI)

\section{QUESTIONS TO ANSWER IN THE OFFICE:}

1. Percent of wetland having very pootty drained soils or Hydric A soils and/or open water.

2. Dominant land use zoning of wetland (see lown zoning map). Use current land use if different from what is zoned.

$$
\begin{aligned}
& \text { Rp, WnC, CmC, HsB, CaB } \\
& \text { (shydric-(most of wet iandis } \\
& \text { on this sol fyre })
\end{aligned}
$$

a. More than 50 percent $\quad 1.0$

b. From 251050 percent $\quad 0.5$

c. Less than 25 percent 0.1

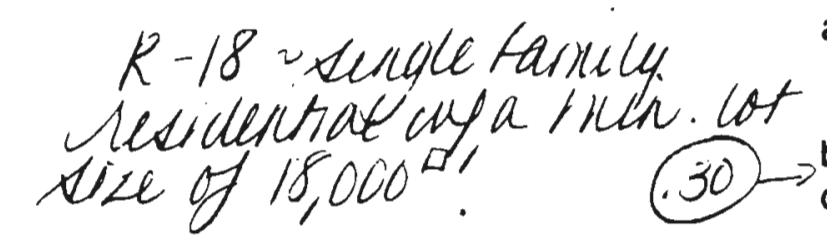

$R-18$ v tengle farnely. residentiat uy a inin. Lot

a. Agriculture, forestry, or similar open space zoning

b. Rural residential

c. CommerciaVindustrial, high density residential

\section{QUESTIONS TO ANSWER IN THE FIELD:}

3. Water quality of the watercourse, pond, or lake associated with the wetland.

a. High: Minimal pollution. $\quad 1.0$
Actual water quality meets or exceeds Class A or $B$ standards

b. Medium: Moderate pollution. Actual water quality is below Class B standards

4. Ratio of the number of occupied buildings within 500 feet of the wetland edge to the total area of the 26 building: I acre wetland (acres).

5. Percent of original wetland filled.

6. Percent of wetland edge bordered by a butfer of woodland or idle land at least 500 feet in width.

a. Less than 1 bldg: 10 acres $(<0.10)$

b. From 1 bldg: 10 acres to 1 bldg: 2 acres $(0.10$. $0.50)$

c. More than 1 bidg: 2 acres (>0.5)

a. Less than 10 percent $\quad 1.0$

6. From 10 to 50 percent 0.5

c. More than 50 percent

a. More than 80 percent

b. From 20 to 80 percent

c. Less than 20 percent

1.0

0.5

0.1

7. Level of human activity WITHIN WETLAND as evi-

a. Low level: Fow trails in $\quad 1.0$ denced by litter, bike trails, roads, residences, etc. use and/or sparse litter

b. Moderate level: Some used trails, roads, etc.

c. High level: Many trails, roads, etc. within welland 


\begin{tabular}{cccc}
\hline$A$ & $B$ & $C$ & 0 \\
$\begin{array}{c}\text { Evaluation } \\
\text { Questions }\end{array}$ & $\begin{array}{c}\text { Computations } \\
\text { or Actual Value }\end{array}$ & $\begin{array}{c}\text { Evaluation } \\
\text { Criteria }\end{array}$ & $\begin{array}{c}\text { Functional Valt } \\
\text { Index (FVI) }\end{array}$ \\
\hline
\end{tabular}

QUESTIONS TO ANSWER IN THE FIELD (continued):

8. Level of human activity IN UPLAND within 500 feet of the wetland edge as evi denced by litter, bike trails, roads, residences, etc.

9. Percent of welland plant community presently being attered by mowing, grazing, farming, or other activity. (Include areas now dominated by phragmites or purple bosestrife).

10. Percent of wetland actively being drained for agriculture or other purposes.

11. Number of public road and/or railroad crossings per 500 teet of wetland (measured along long axis of wetland).

12. Long-term stability. a. Low level: Few trails in use 1.0 and/or sparse litter

(b) Moderate level: Some trails, 0.5 scattered residences, etc.

c. High level: Many trails, roads, etc. within upland
a. Less than 10 percent
b. From 10 to 50 percent
c. More than 50 percent

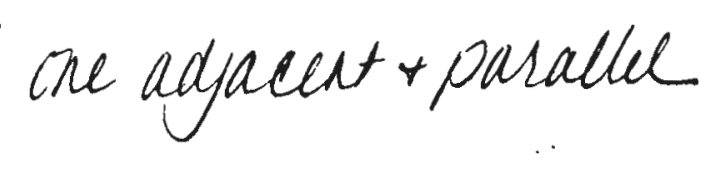

a. None

Two or more a. Wetland appears 10 be
naturally occurring, not impounded by dam or dike

b. Wetland appears to be somewhat dependemt on antificial diking by dam. road, fill, etc.

AVERAGE FVI FOR FUNCTIONAL VALUE $1=$ Average of column D $=.708(8.5 \div 12)$

EVALUATION AREA FOR FUNCTIONAL VALUE 1 = Total area of welland acres. 


\section{NEEDED FOR THIS EVALUATION:}

- USGS topographic map

- Land use map and/or recent aerial photographs

- Ruler or scalo

- A method to calculate area (Dot grid, planimeter, etc.)

- N.H. Water Quality Report to Congress 305(b)

\section{A}

Evaluation

Ouestions
Computations

or Actual Value
Evaluation

Criteria
D

Functional Valu Index (FVI)

\section{QUESTIONS TO ANSWER IN THE OFFICE:}

1. Ecological integrity.

Average FVI from Functional Value 1

2. Area of shallow permanent open water (less than 6 feet deep) including streams

a More than 3 acres

b. From 0.5 to 3 acres

in or adjacent to wetland.

\section{QUESTIONS TO ANSWER IN THE FIELD:}

3. Water quality of the watercourse,

FVI from Question V.1.3 lake, or pond associated with the wetland.

4. Wetland diversity.

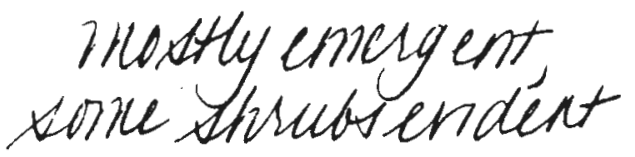

a. Three or more wetland classes present

b. Two wetland classes present

c. One wetland class present

5. Dominant wetland class.

6. Interspersion of vegetation classes and/or open water. a. Emergent marsh and/or shallow $\quad 1.0$ open water

b. Forested and/or scrub-shnub wetland 0.5

c. Scrub-shnub saturated $(\mathrm{bog})$ or $\quad 0.1$ wet meadow

a. At least two wetland classes highly 1.0 interspersed. Areas of each class scattered within wetland like a patchwork quilt

b. Moderate interspersion of wetland 0.5 classes

c. Low degree of interspersion. Each tiguous and separate from the other classes 


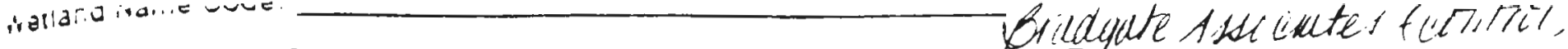

WETLAND WILDLIFE HABITA

(cominued)

\begin{tabular}{cccc}
\hline A & $\mathbf{B}$ & $\mathrm{C}$ & 0 \\
$\begin{array}{c}\text { Evaluation } \\
\text { Questions }\end{array}$ & $\begin{array}{c}\text { Computations } \\
\text { or Actual Value }\end{array}$ & $\begin{array}{c}\text { Evaluation } \\
\text { Criteria }\end{array}$ & $\begin{array}{c}\text { Functional Value } \\
\text { Index (FVI) }\end{array}$ \\
\hline
\end{tabular}

7. Wetland juxtaposition.

8. Number of islands or inclusions of upland within wetland.

9. Wildlife access to other wetlands (overiand). Travel travel leaues wndel 10 ad
lanes should be 50-100 leet wide.
10. Percent of welland edge bordered by upland wildise habitat (brush, woodland, active farmland, or idle land) at least 500 feet in width. arong stream. Coindoris at teast 50' wide. a. Wetland connected to other 1.0 wetlands within a 1 mile radius by perennial stream or lake

b. Wetland connected to other wetlands within a 1 to 3 mile radius by perennial stream or lake, OR other unconnected wellands are present within a 1 mile radius

c. Wetland not hydrologically connected to other wetlands within 3 miles and no other unconnected wetlands within 1 mile

a. Two or more

c. None (a.)

Free access abng well vegetated stream comidor. woodland, or lakeshore

b. Access partially blocked by roads, urban areas, or other obstructions

c. Access blocked by roads, urban areas, or other obstructions

\section{0

5

2. More than 40 percent

(b.) From 101040 percent

c. Less than 10 percent

AVERAGE FVI FOR FUNCTIONAL VALUE 2 = Average of column $0=.801 .(8.008 \div 10)$ EVALUATION AREA FOR FUNCTIONAL VALUE 2 = Total area of wetland = acres. 
जelland name or code KVOKingham Mall

couny Ruckingham town Salem, NH

investigator(s)

A

Functlonal

Value

1. Ecological integrity

2. Wildlife Habitat

3. Finfish Habitat:

3. Finfish Habitat:

Part A - Rivers and Streams

Part $B$ - Ponds and Lakes

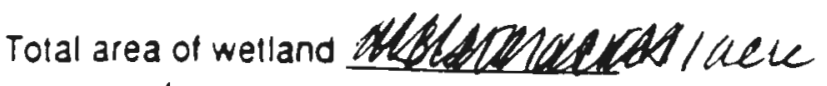

Date Alugust 31,1991

4. Educational Potential

5. VisuaVAesthetic Ouality

6. Water Based Recreation

7. Flood Control Potential

8. Ground Water Use Potential

9. Sediment Trapping

10. Nutrient Attenuation

11. Shoreline Anchoring and

Dissipation of Erosive Forces

12. Utoan Quality of Life

8: Wildlife Habitat

C: Educational Opportunity

D: VisuaVAesthetic Quality

E: Water Based Recreation

13. Historical Site Potential

14. Noteworthiness

\section{B \\ FVI From \\ Data Sheots}

.425

.323

l
Slze of Evaluation

Area (Acres)
Wetland Value Units

$B \times C$

1.425

.373

total .798 
NEEDED FOR THIS EVALUATION:

- Zoning mã̃

- SCS soils map

- N.H. Water Quality Report to Congress 305(b)

- USGS topographic map or recent aerial pholograph

- A method to calculate area (Dot grid, planimeter, etc.)

- Ruler or scale

- Map wheel (Optional)

\section{A}

Evaluation

Questions
Klek Illy llurl que

Functional value 1 Hydric A soils and/or open water.

2. Dominant land use zoning of wetland (see town zoning map). Use currem land use if CommerwallIndustrial different from what is zoned.

\section{QUESTIONS TO ANSWER IN THE FIELD:}

3. Water quality of the watercourse, pond, or lake associated with the wetland.

\section{Porceupine Brook}

$$
" b "
$$

because the wettand

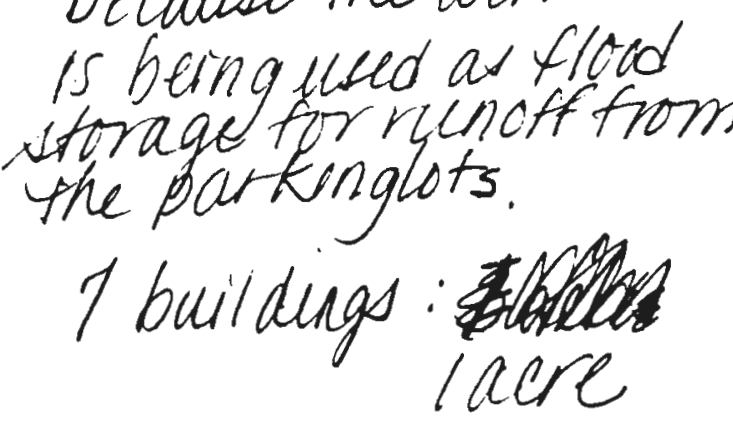

4. Ratio of the number of occupied buildings within 500 feet of the wetland edge to the total area of the wetland (acres).

5. Percent of original wetland fiiled.

filled gaeres

6. Percent of wetland edge bordered by a butfer of woodland or idle land at least 500 feet in width.

7. Level of human activity WITHIN WETLAND as evidenced by litter, bike trails. roads, residences, etc.

\section{all fenced in}

a. More than 50 percent 1.0

b. From 25 to 50 percent 0.5 Less than 25 percent

0.1

a. Agriculture, forestry, or similar open space zoning

b. Rural residential

c. Commercialindustrial, high density residential

1.0

Figh: Minimal pollution.

IActual water quality meets or exceeds Class A

or $\mathrm{B}$ standards

b. Medium: Moderate pollution. Actual water quality is below Class B standards

a. Less than 1 bldg: 10 acres (<0.10)

b. From 1 bldg: 10 acres to 1 blog: 2 acres $(0.10$. 0.50)

C. More than 1 bidg: 2 acres (>0.5)

a. Less than 10 percent b. From 10 to 50 percent c. More than 50 percent

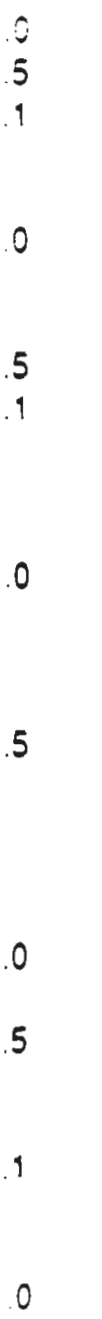

From 20 to 80 percent 0.5

c. Less than 20 percent 0.1

a. Low level: Few trails in 10 use andror sparse litter

b. Moderate level: Some used trails, roads, etc.

c. High level: Many trails, roads, etc. within wetland 


\begin{tabular}{cccc} 
A & B & $C$ & Computations \\
$\begin{array}{c}\text { Evaluation } \\
\text { Questions }\end{array}$ & $\begin{array}{c}\text { Comaluation } \\
\text { Cr Actual Value }\end{array}$ & $\begin{array}{c}\text { Functional Va: } \\
\text { Index (FVI) }\end{array}$ \\
\hline
\end{tabular}

QUESTIONS TO ANSWER IN THE FIELD (continued):

8. Level of human activity in HWW.4 Hall $\$$ Roads + Ree den CES UPLAND within 500 feet of the wetland edge as evi denced by litter, bike trails, roads, residences, etc.

9. Percent of wetland plant community presently being altered by mowing, grazing.

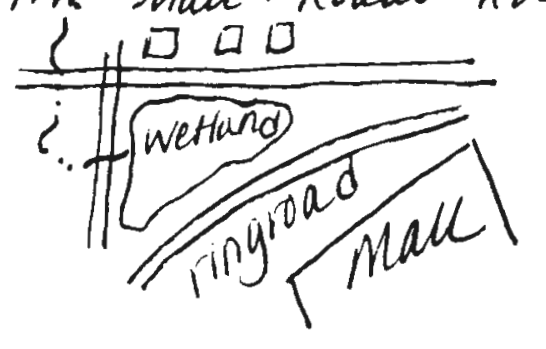
larming, or other activity. (Include areas now dominated by phragmites or purple bosestrife).

10. Percent of wetland actively being drained for agriculture or other purposes.

11. Number of public road and/or railroad crossings per 500 feet of wetland (measured along long axis of wetland).

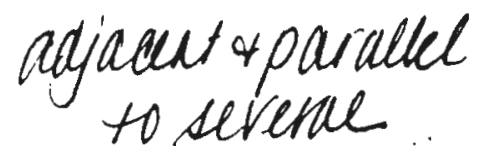

12. Long-term stability.

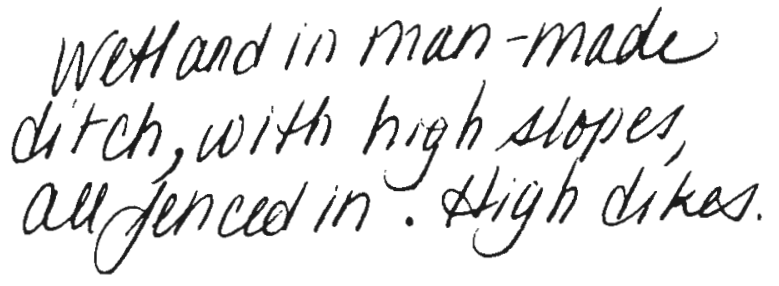

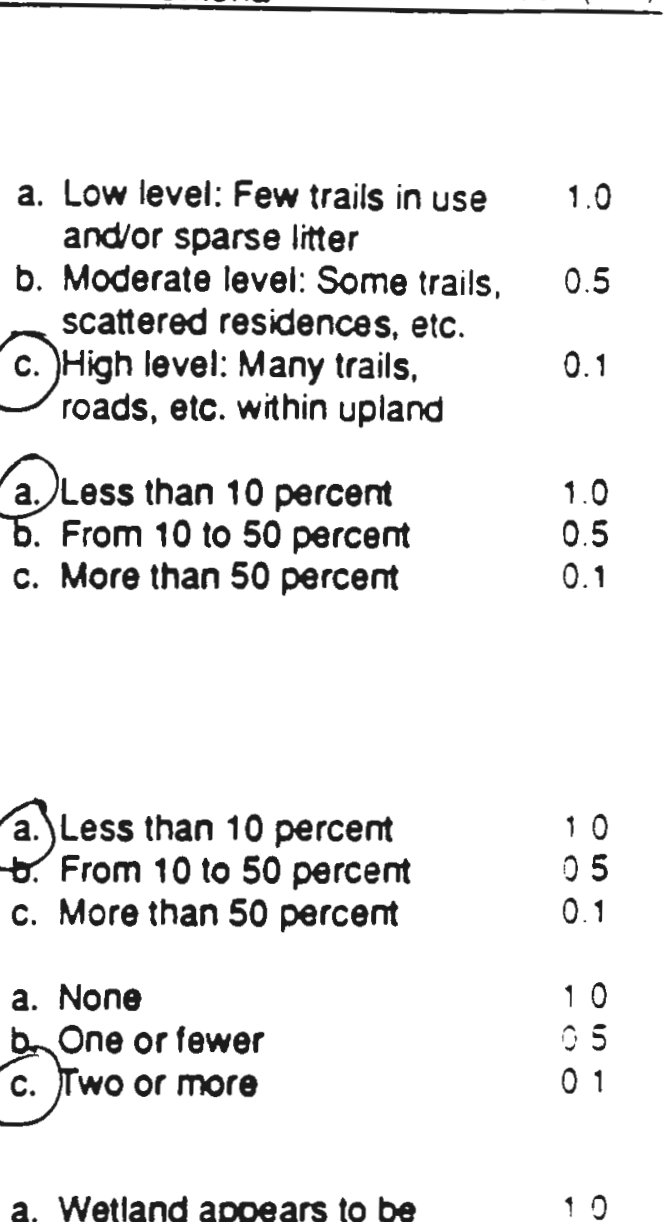

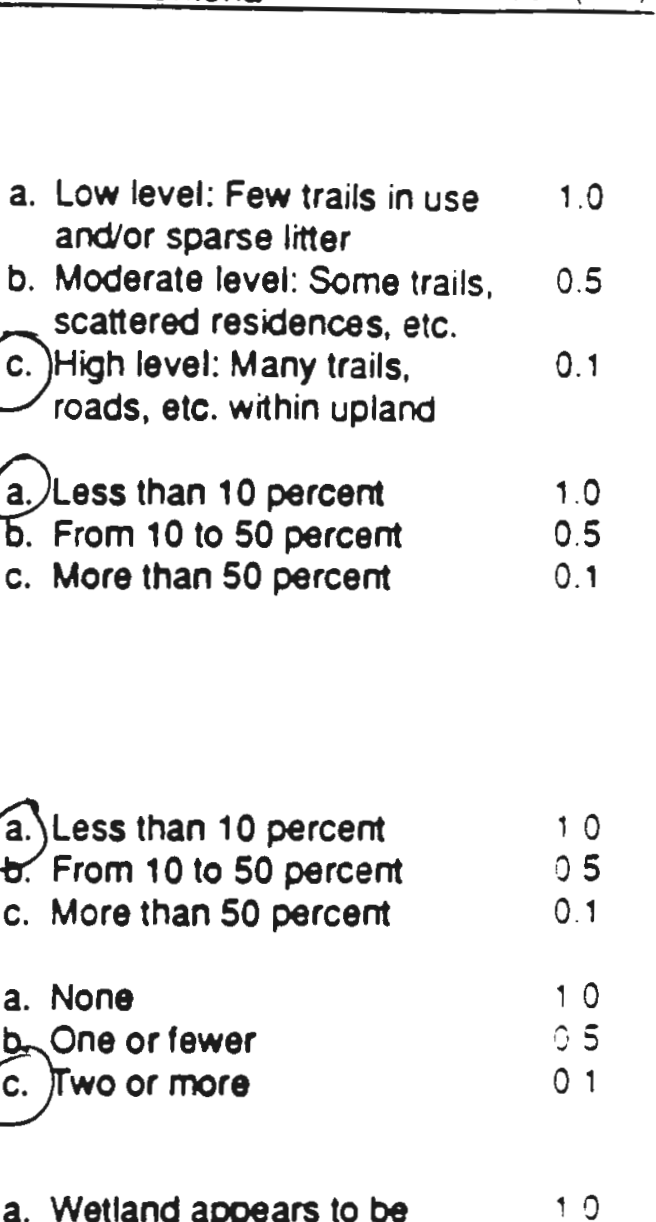

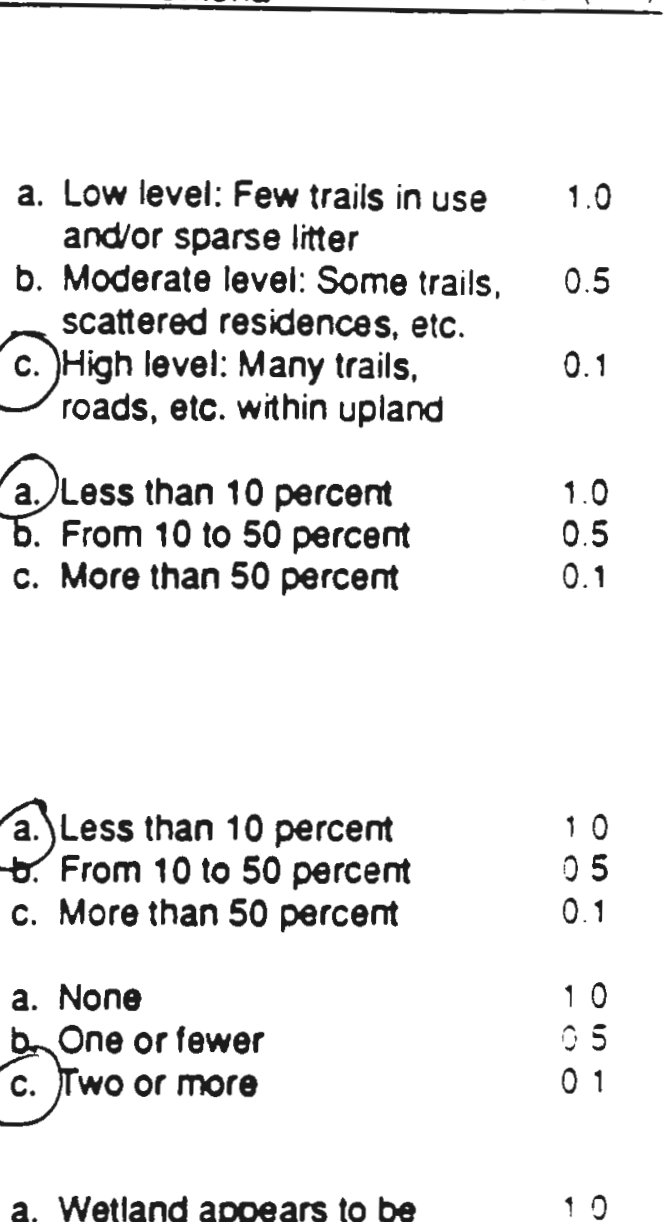

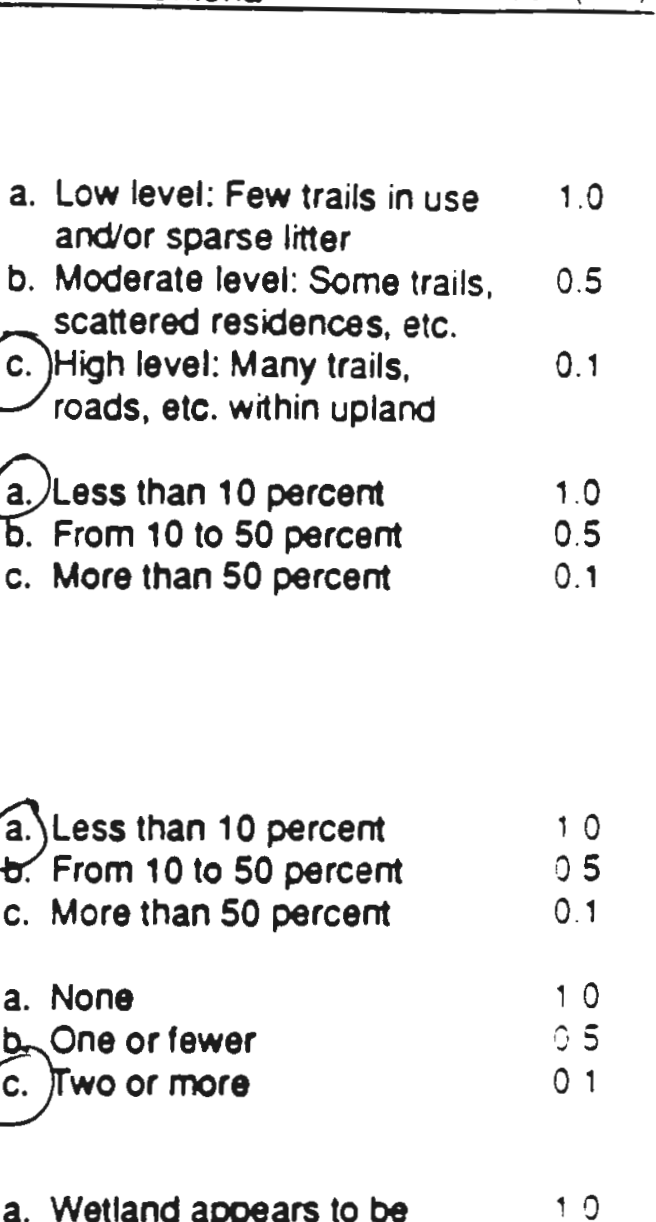

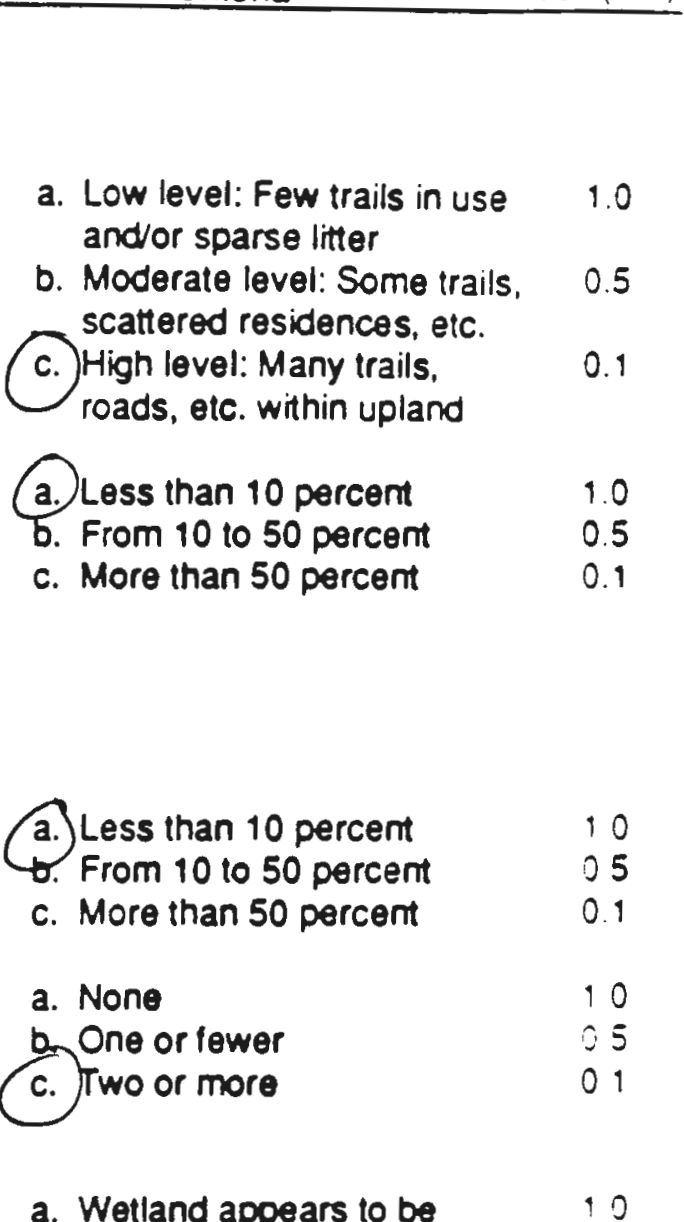

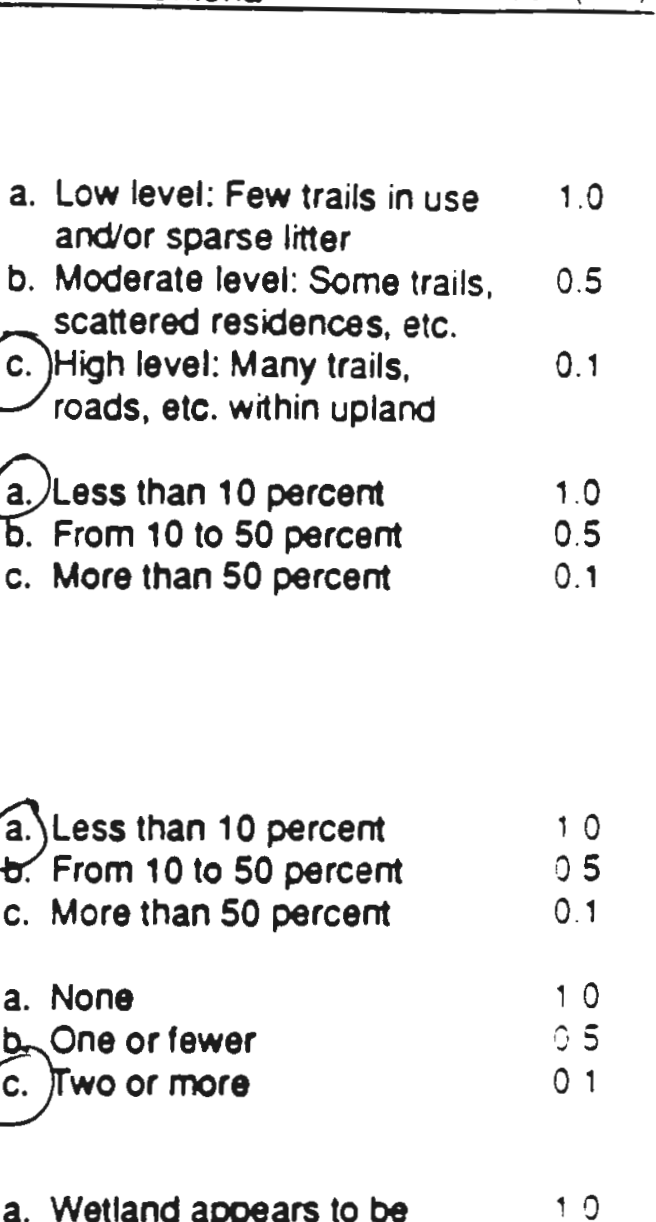

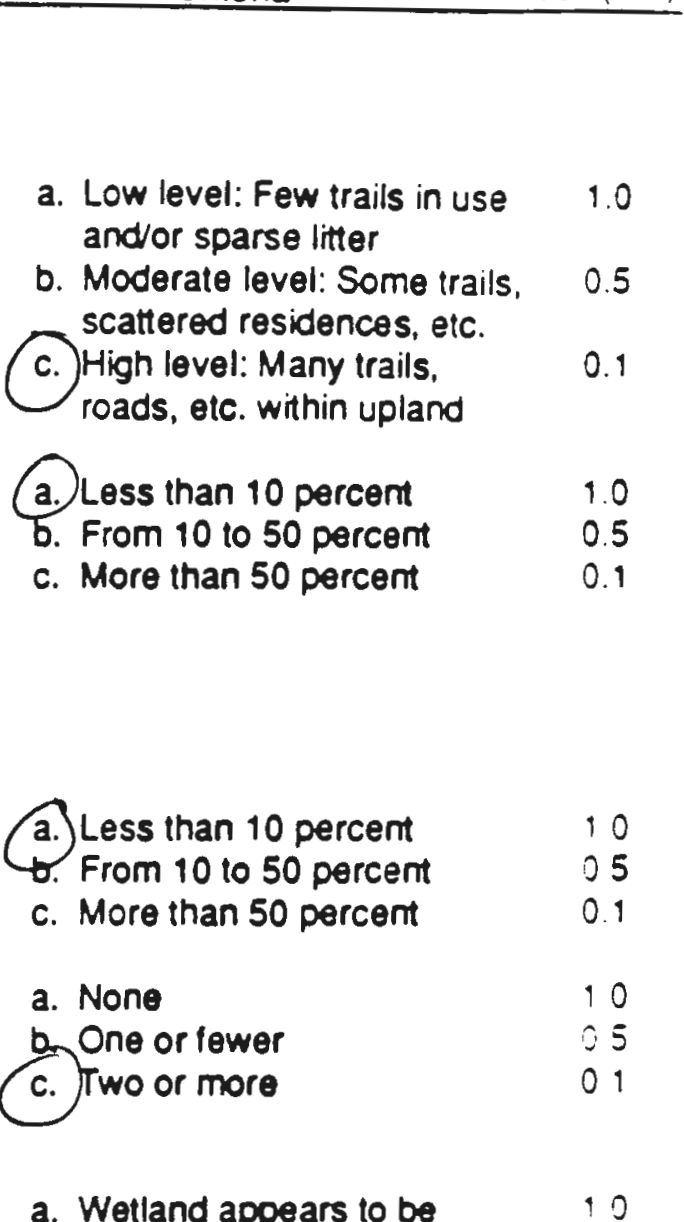

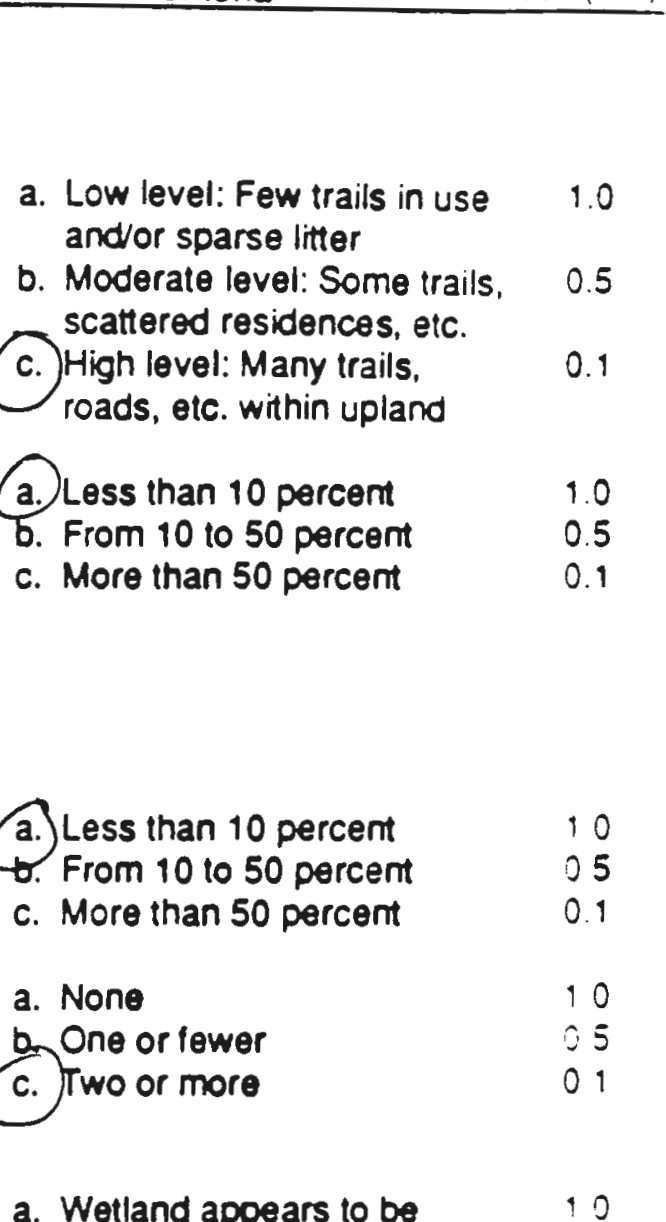

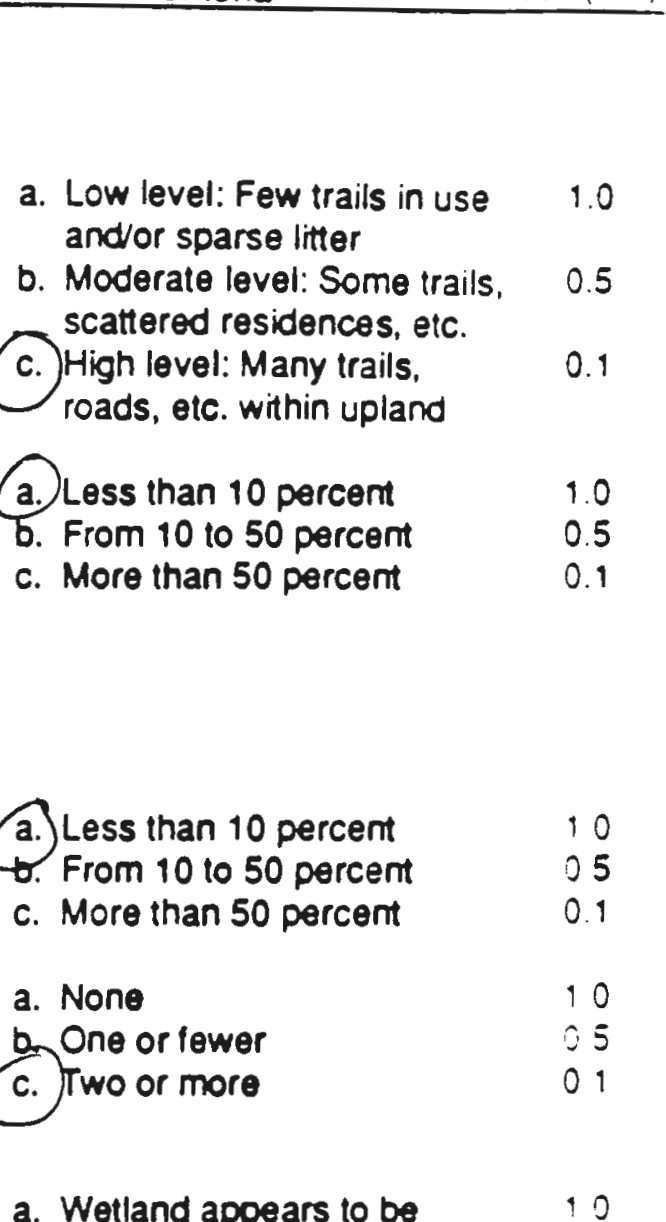

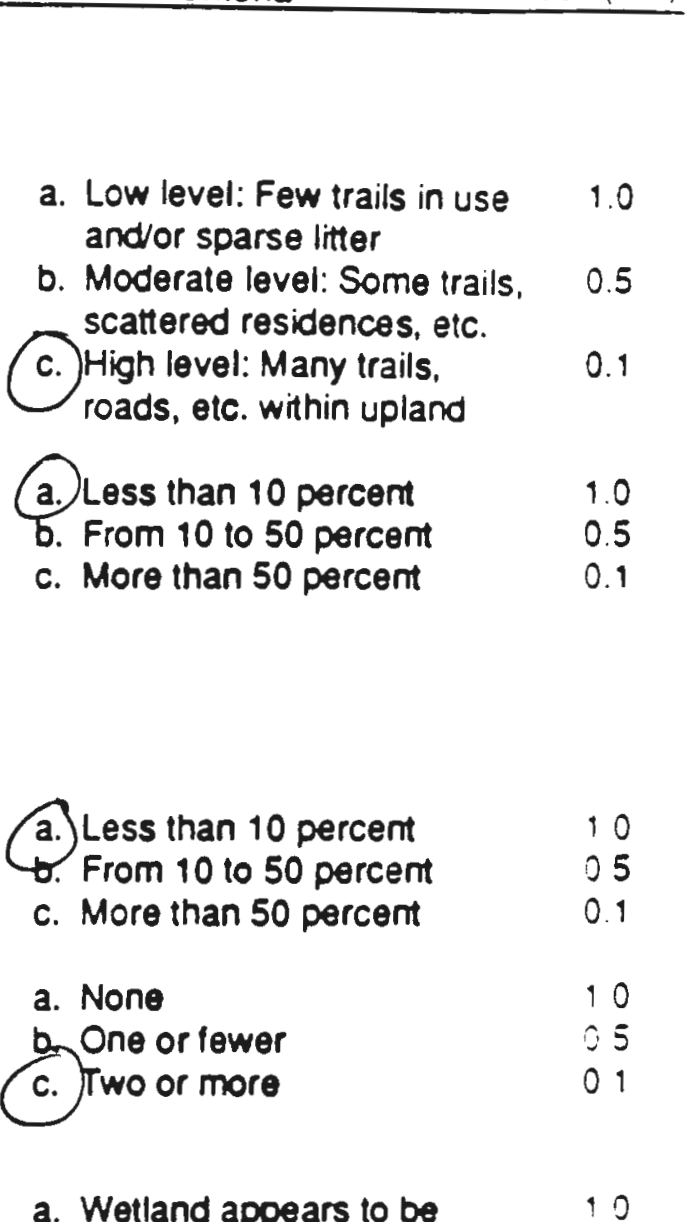

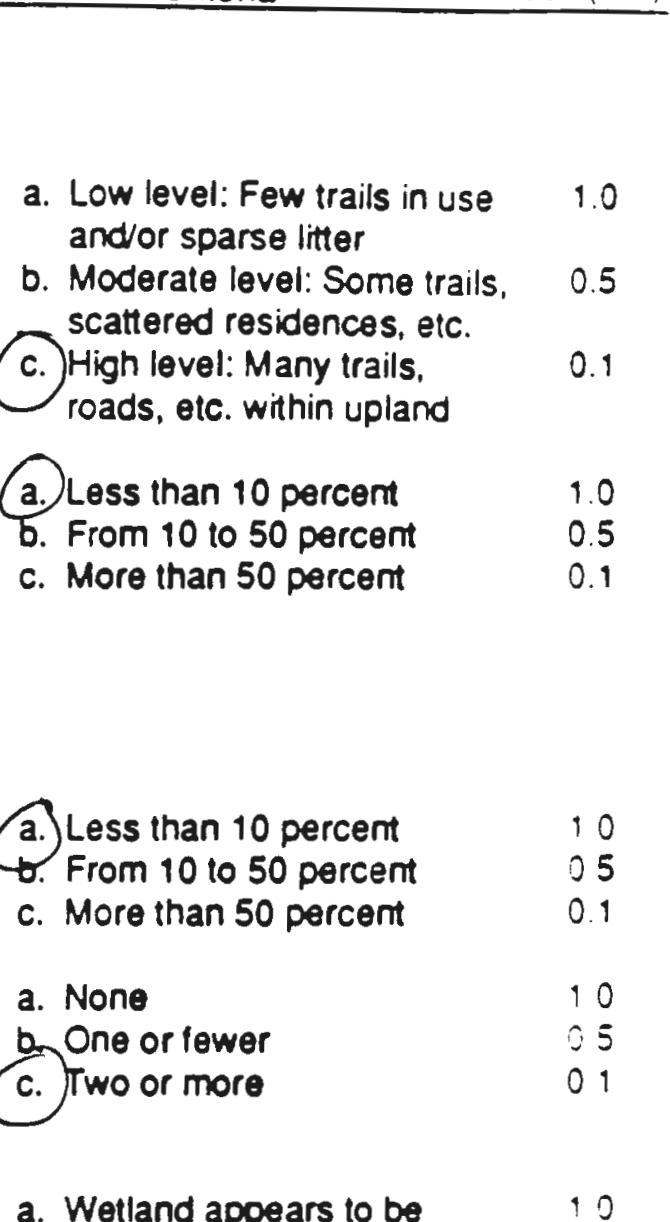

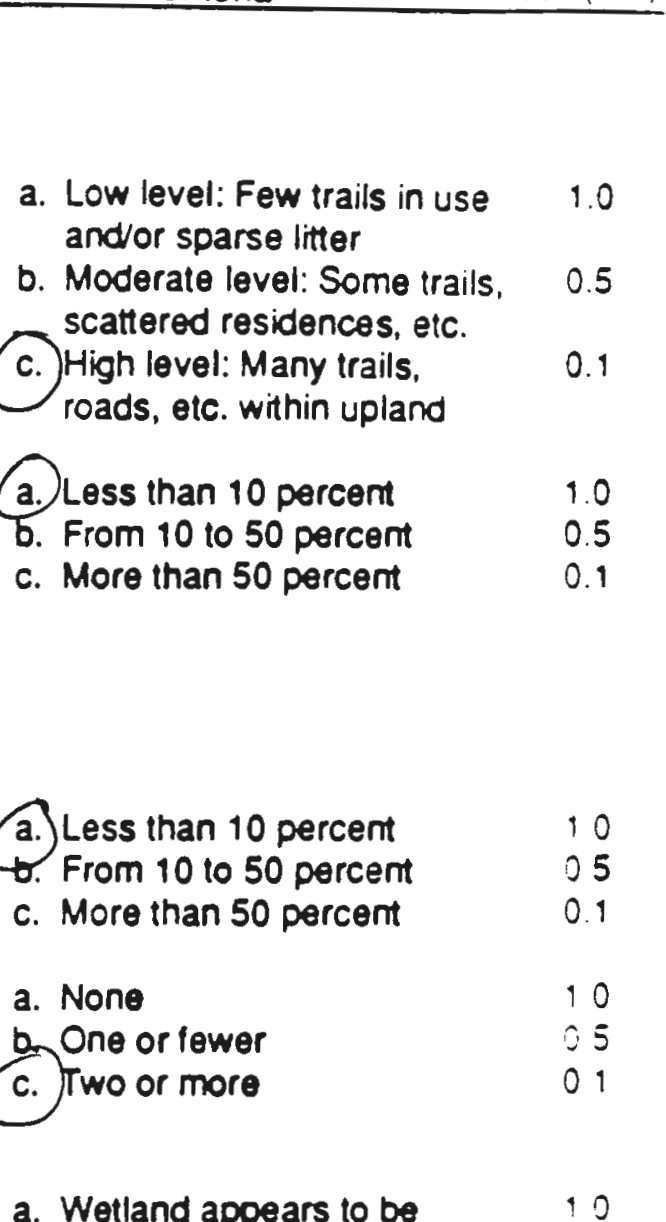

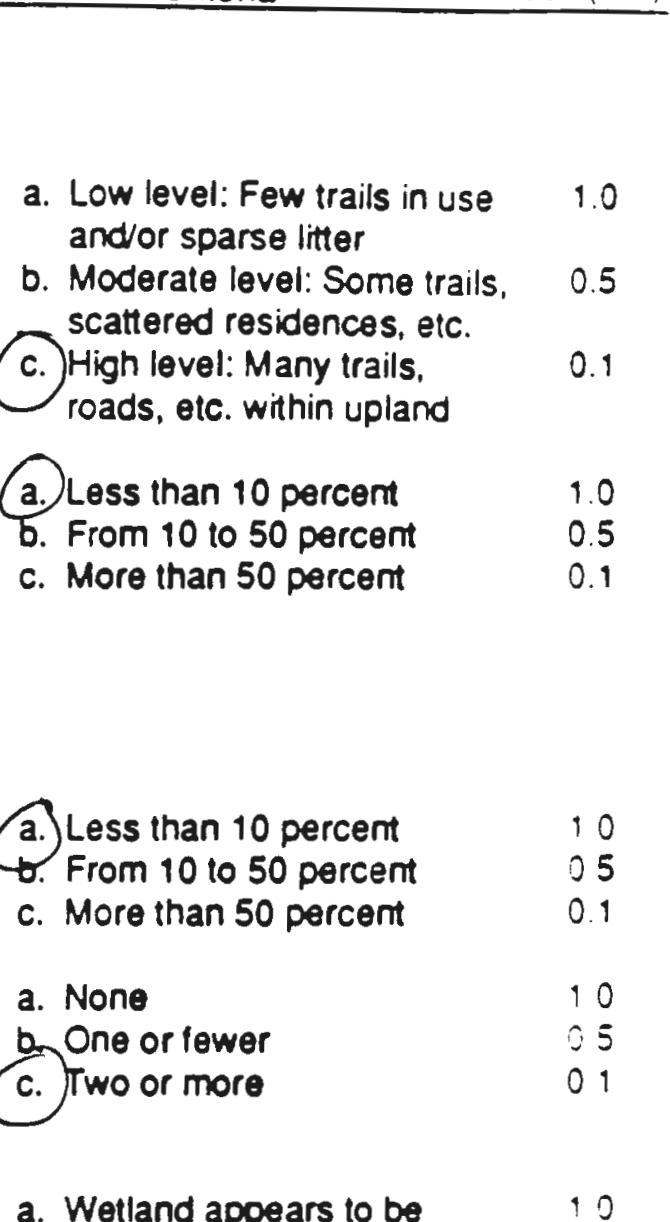

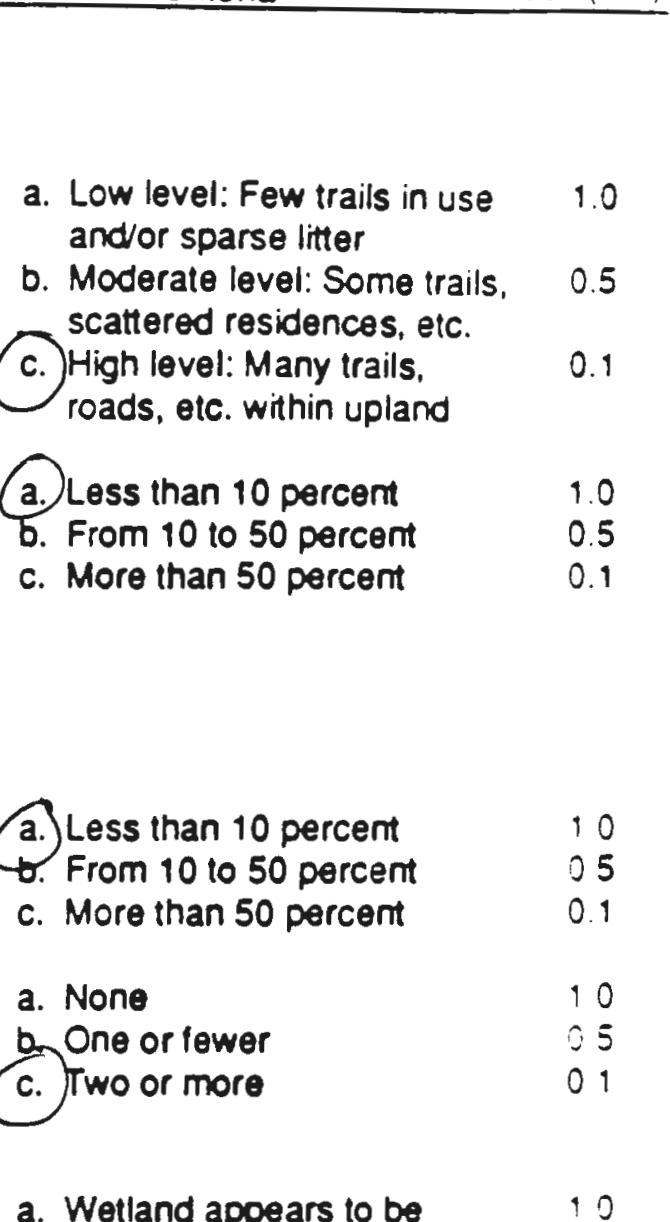

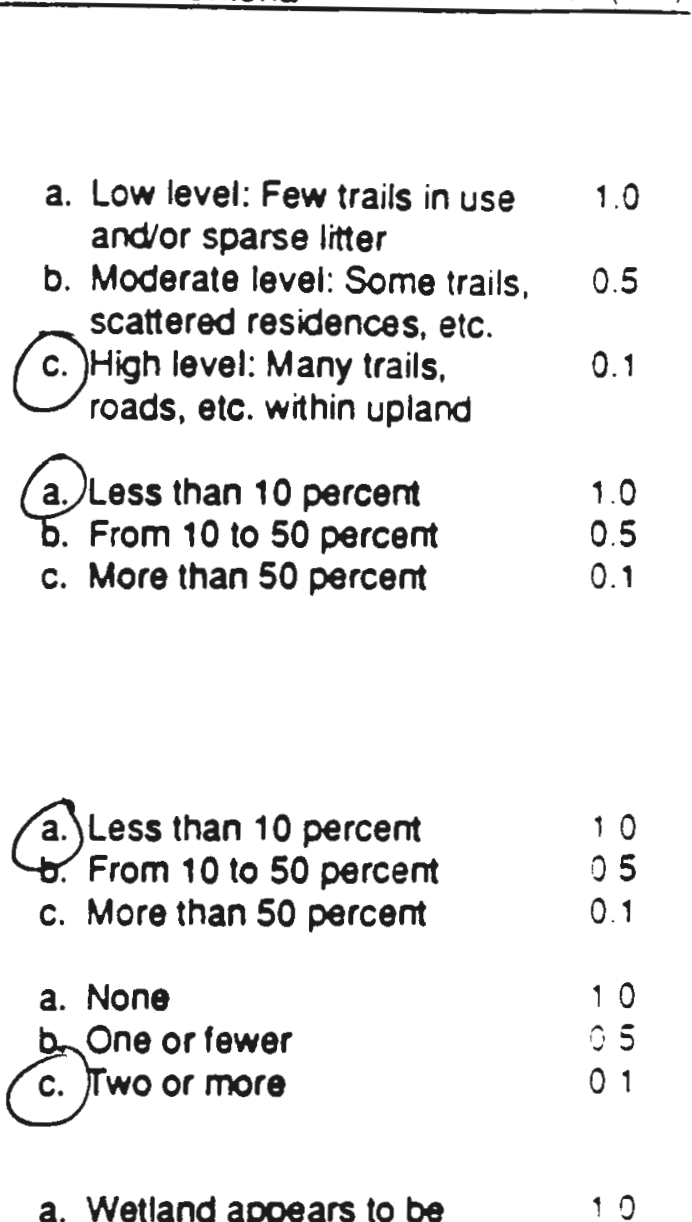

a. Wetland appears to be 10 naturally occurring, not impounded by dam or dike

b. Wetland appears to be $: 5$ somewhat dependent on artificial diking by dam. road, fill, elc.

AVERAGE FVI FOR FUNCTIONAL VALUE $1=$ Average of column D $=.425 \cdot(5.1 \div 12)$

EVALUATION AREA FOR FUNCTIONAL VALUE 1 = Total area of wetland acres. 
- USGS topographic map

- Land use map and/or recent aerial photographs

- Ruler or scale

- A method to calculate area (Dot grid, planimeter, etc.)

- N.H. Water Quality Report to Congress 305(b)

\section{A}

Evaluation

Questions

\section{B}

Computations

or Actual Value
C

Evaluation

Criteria
Functional Value Index (FVI)

\section{QUESTIONS TO ANSWER IN THE OFFICE:}

1. Ecological integrity.

2. Area of shallow permanent open water (less than 6 feet

deep) including streams

in or adjacent to wetland.
Average FVI from Functional Value 1

.425

a. More than 3 acres

1.0

b. From 0.5 to 3 acres

c. Less than 0.5 acre

\section{QUESTIONS TO ANSWER IN THE FIELD:}

3. Water quality of the watercourse,

FVI from Question V.1.3

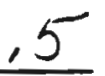

lake, or pond associated with the welland.

4. Wetland diversity.

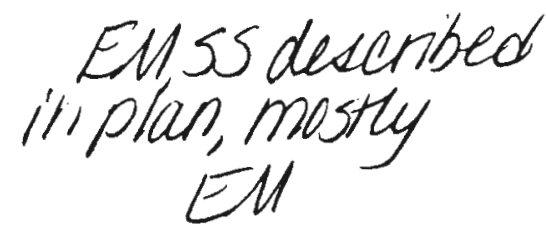

a. Three or more wetland classes

1.0 present

b. Two wetland classes present

c. One wetland class present

0.5

0.1

5. Dominant wetland class.

a. Emergent marsh and/or shallow $\quad 1.0$ open water

b. Forested and/or scrub-shnub wetland 0.5

c. Scrub-shrub saturated (bog) or wet meadow

6. Interspersion of vegetation classes and/or open water.

a. At least two wetland classes highly interspersed. Areas of each class scattered within wetland like a patchwork quilt

b. Moderate interspersion of wetland classes

c. Low degree of interspersion. Each wetland class is more or less contiguous and separate from the other classes 


\begin{tabular}{cccc}
\hline A & $B$ & $C$ & $D$ \\
Evaluation & Computations & Evaluation & Functional Value \\
Questions & or Actual Value & Criteria & incex (FVI) \\
\hline
\end{tabular}

7. Wetland juxtaposition.

8. Number of islands or inclusions of upland within wetland.

9. Wildife access to other wetlands (overland). Travel lanes should be 50-100 leet wide.

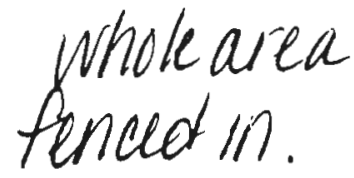

10. Percent of wetland edge bordered by upland wild"te habitat (brush, woodland. active farmland, or idle land) at least 500 feet in width. a. Wetland connected to other wellands within a i mile radius by perennial stream or lake

b. Wetland connected to other wellands within a i 103 mile radius by perennial stream or lake, OR other unconnected wellands are present within a 1 mile radius

c. Wetland not hydrologically connected to other wetlands within 3 miles and no other unconnected wetlands within 1 mile

a. Free access abong well vegetated stream comidor. woodland, or lakeshore

b. Access partially blocked by roads, utban areas, or other obstructions

c. Access blocked by roads, urban areas, or other obstruc.

5
tions 


\section{SUMMARY SHEET FOR THE N.H. METHOD}

welland name or code Rickingham Mall(COmno / Site), rotal area of welland

county Reckingh ail town Sulen, NH

investigators) Sfaci Holcombe, Darid Hulseberg

\section{$A$}

Functional

Value

1. Ecological Integrity

2. Wildife Habitat

3. Finfish Habitat:

Part A - Rivers and Streams

Part 8 - Ponds and Lakes
$\mathrm{C}$

FVI From

Data Shoots

$.8 \gamma 3$

.728

Lize of Evaluation

Area (Acres)

1.5

1.5
Wetland Value Units

$B \times C$

1.325

1.092

4. Educational Potential

5. VisualyAesthetic Quality

6. Water Based Recreation

7. Flood Comrol Potential

8. Ground Water Use Potential

9. Sediment Trapping

10. Nutrient Attenuation

11. Shoreline Anchoring and

Dissipation of Erosive Forces

12. Urian Quality of Life

B: Wildlife Habitat

C: Educational Opportunity

D: VisuaVAesthetic Ouality

E: Water Based Recreation

13. Historical Site Potential

14. Noteworthiness 
- Zoning mấ

- SCS soils map

- N.H. Water Ouality Report to Congress 305(b)

- USGS lopographic map or recent aerial pholograph

- A method to calculate area (Dot grid, planimeter, etc.)

- Map wheel (Optional) (Af Und of VAfs

$$
\text { A }
$$

Evaluation

Questions
Memonial thighway)

Computations

or Actual Value
Evaluation

Criteria
Functional Valu. Index (FVI)

\section{QUESTIONS TO ANSWER IN THE OFFICE:}

1. Percent of welland having very poorly drained soils or Hydric A soils and/or open water.

2. Dominant land use zoning of welland (see town zoning map). Use current land use if

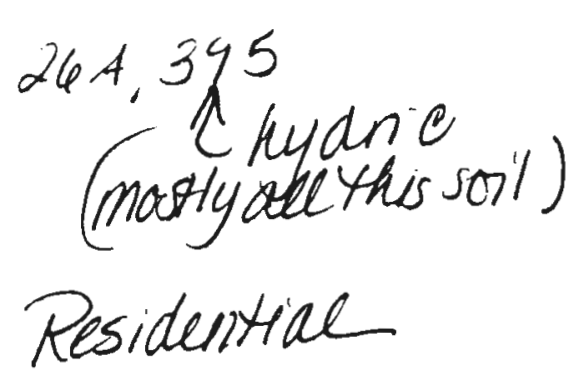
different from what is zoned.
(a. More than 50 percent
b. From 25 to 50 percent 0.5
c. Less than 25 percent
0.1

\section{QUESTIONS TO ANSWER IN THE FIELD:}

a. Agriculture, forestry, or $\quad 1.0$ similar open space zoning

b. Rural residential $\quad 0.5$

c. Commercialindustrial, $\quad 0.1$

3. Water quality of the watercourse, pond, or lake associated with the welland.
4. Ratio of the number of occupied buildings within 500 leet of the wetland edge to the total area of the wetland (acres).

5. Percent of original wetland filled.

6. Percent of welland edge bordered by a butfer of woodland or idle land at least 500 leet in width.

7. Level of human activity WITHIN WETLAND as evidenced by litter, bike trails, roads, residences, etc.

\section{¿ houses: incros}
a. High: Minimal pollution. $\quad 1.0$ Actual water quality meets or exceeds Class A or B standards
b. Medium: Moderate pollu- tion. Actual water quality is below Class B stan- dards

a. Less than 1 bldg: 10 acres $(<0.10)$

b. From 1 blog: 10 acres to 1 bldg: 2 acres $(0.10$ -

(c. 0.50$)$

c. More than $1 \mathrm{bldg}$ : 2 acres $(>0.5)$

a Less than 10 percent

b. From 10 to 50 percent

c. More than 50 percent use andyor sparse litter

b. Moderate level: Some used trails, roads, etc.

c. High level: Many trails, roads, elc. within wetland 


\section{NEEDED FOR THIS EVALUATION:}

- USGS topographic map

- Land use map and/or recont aerial photographs

- Ruler or scale

- A method to calculate area (Dot grid, planimeter, etc.)

- N.H. Water Quality Report to Congress 305(b)

\begin{tabular}{cccc}
\hline A & B & C & D \\
Evaluation & Computations & Evaluation & Functional Valt \\
Questions & or Actual Value & Criteria & Index (FVI) \\
\hline
\end{tabular}

\section{QUESTIONS TO ANSWER IN THE OFFICE:}

1. Ecological integrity.

Average FVI from Functional Value 1

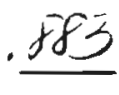

2. Area of shallow permanent

a. More than 3 acres open water (less than 6 feet deep) including streams in or adjacent to wetland.

b. From 0.5 to 3 acres

c. Less than 0.5 acre

\section{QUESTIONS TO ANSWER IN THE FIELD:}

3. Water quality of the watercourse, lake, or pond associated with the wetland.

4. Wetland diversity.

a. Three or more wetland classes presem

b. Two wetland classes present

c. One wetland class present

5. Dominamt wetland class.

a. Emergent marsh andyor shallow

open water

b. Forested and/or scrub-shrub welland 05

c. Scrub-shrub saturated $(\mathrm{bog})$ or wet meadow

6. Interspersion of vegetation classes and/or open water.

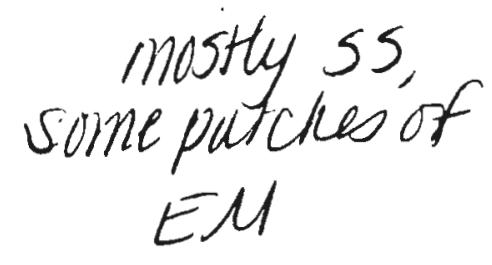

a. At least two wetland classes highly interspersed. Areas of each class scattered within wetland like a patchwork quit

b. Moderate interspersion of wetland

classes

c. Low degree of interspersion. Each welland class is more or less con. tiguous and separate from the other classes 


\begin{tabular}{|c|c|c|c|}
\hline $\begin{array}{c}\text { A } \\
\text { Evaluation } \\
\text { Questions }\end{array}$ & $\begin{array}{c}\text { B } \\
\text { Computations } \\
\text { or Actual Value } \\
\end{array}$ & $\begin{array}{c}\text { C } \\
\text { Evaluation } \\
\text { Criteria } \\
\end{array}$ & $\begin{array}{c}\text { Functional Va! } \\
\text { index (FVI) }\end{array}$ \\
\hline
\end{tabular}

QUESTIONS TO ANSWER IN THE FIELD (continued):

8. Level of human activity IN UPLAND within 500 foel of the wetland edge as evi denced by litter, bike trails, roads, residences, etc.

9. Percent of wetland plant community presently being altered by mowing, grazing. farming, or other activity. (Include areas now dominated by phragmites or purple bosestrite).

10. Percent of wetland actively being drained for agriculture or other purposes.

11. Number of public road and/or railroad crossings per 500 feet of wetland (measured along long axis of wetland).

12. Long-term stability.

\author{
clead end street - 2 house
(a.) Low level: Few trails in use 1.0 and/or sparse litter
b. Moderate level: Some trails, $\quad 0.5$ scattered residences, etc.
c. High level: Many Irails, roads, etc. within upland \\ a. Less than 10 percent \\ b. From 10 to 50 percent \\ c. More than 50 percent \\ 1.0 \\ 0.5 \\ 0.1
}

$\begin{array}{ll}\text { a. Less than } 10 \text { percent } & 10 \\ \text { b. From } 10 \text { to } 50 \text { percent } & 0.5 \\ \text { c. More than } 50 \text { percent } & 0.1\end{array}$

(2) None

b. One or fewer

c. Two or more

1.0

0.5

0.1

a. Wetland appears to be $\quad 1.0$ naturally occurring. not impounded by dam or dike

b. Wetland appears to be somewhat dependent on artificial diking by dam, road, fill, etc.

AVERAGE FVI FOR FUNCTIONAL VALUE $1=$ Average of column $0=.883(10.6-12)$

EVALUATION AREA FOR FUNCTIONAL VALUE 1 = Total area of wetland = acres. 
(continued)

\begin{tabular}{cccc}
\hline Evaluation & $B$ & $C$ & $D$ \\
Questions & Computations & Evaluation & Functional Value \\
Index (FVI)
\end{tabular}

7. Wetland juxtaposition.

8. Number of islands or inclusions of upland within wetland.

9. Wildlife access to other wetlands (overland). Travel lanes should be 50-100 leet wide.

10. Percent of wetland edge bordered by upland wildite habitat (brush, woodland, active farmland, or idle land) $\operatorname{cots} y$ hills at least 500 teet in width. a.

a. Wetland connected to other 1.0 wetlands within a 1 mile radius by perennial stream or lake

b. Wetland connected to other wetlands within a 1 to 3 mile radius by perennial stream or lake, OR other unconnected wetlands are present within a 1 mile radius

c. Wetland not hydrologically connected to other wetlands within 3 miles and no other unconnected wetlands within 1 mile
a. Two or more
1.0
b. One
0.5
c. None
0.1
a. Free access abong well $\quad 1.0$ vegetated stream corridor. woodland, or lakeshore
b. Access partially blocked by roads, uban areas, or other obstructions
c. Access blocked by roads, urban areas, or other obstruc. tions

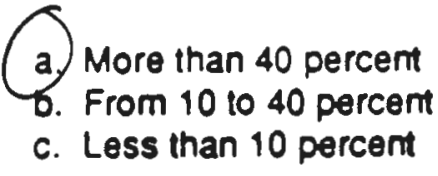

\footnotetext{
AVERAGE FVI FOR FUNCTIONAL VALUE $2=$ Average of column D $=.728 .(1.283 \div 10)$

EVALUATION AREA FOR FUNCTIONAL VALUE $2=$ Tolal area of wetland $=1.5$ acres.
} 


\section{SUMMARY SHEET FOR THE N.H. METHOD}

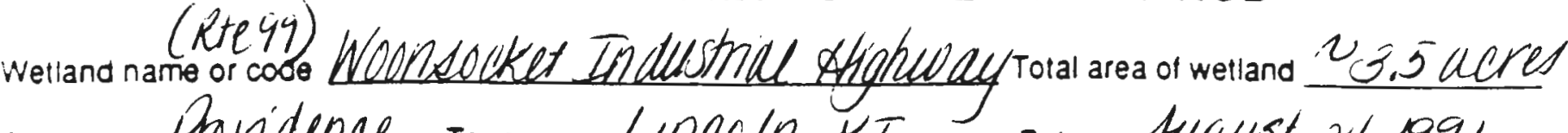

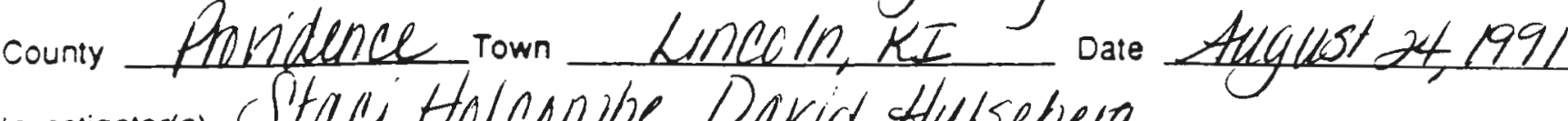
investigator(s) S'fali Holconibe, Darid thuseberg

\begin{tabular}{|c|c|c|c|}
\hline $\begin{array}{c}A \\
\begin{array}{c}\text { Functional } \\
\text { Value }\end{array}\end{array}$ & $\begin{array}{c}\text { 8 } \\
\text { FVI From } \\
\text { Data Shoots }\end{array}$ & $\begin{array}{l}\text { C } \\
\text { Slze of Evaluation } \\
\text { Area (Acres) }\end{array}$ & $\begin{array}{c}0 \\
\text { Wetland Value Unths } \\
8 \times C\end{array}$ \\
\hline Ecological Integrity & .758 & 3.5 & 2.653 \\
\hline 2. Wildirite Habitat & .876 & 3.5 & 3.066 \\
\hline $\begin{array}{l}\text { 3. Fintish Habitat: } \\
\text { Pant A - Rivers and Streams }\end{array}$ & & total & 5.719 \\
\hline
\end{tabular}

4. Educational Potential

5. VisuaVAesthetic Quality

6. Water Based Recreation

7. Flood Control Potential

8. Ground Water Use Potential

\section{Sediment Trapping}

10. Nutrient Attenuation

11. Shoreline Anchoring and

Dissipation of Erosive Forces

12. Urban Quality of Life
B: Wildlife Habitat
C: Educational Opportunity
D: VisuaVAesthetic Quality
E: Water Based Recreation

13. Historical Site Potential

14. Noleworthiness 
NEEDED FOR THIS EVALUATION:

- Zoning mã

- SCS soils map

- N.H. Water Quality Report to Congress 305(b)

- USGS topographic map or rocent aerial pholograph

- A method to calculate area (Dot grid, planimeter, etc.)

- Ruler or scale

- Map wheel (Optional)

A

Evaluation

Questions
Computations or Actual Value
K+e. 94

Functional Value 1

ECOLOGICAL INTEGRITY

\section{QUESTIONS TO ANSWER IN THE OFFICE:}

1. Percent of wetland having very poorly drained soils or Hydric A soils and/or open water.

2. Dominant land use zoning of wetland (see town zoning map). Use current land use it ditferent from what is zoned.
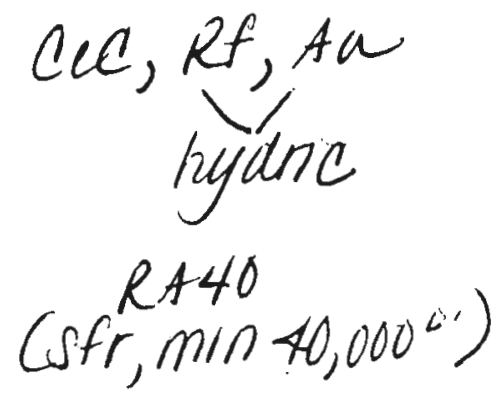

\section{QUESTIONS TO ANSWER IN THE FIELD:}

3. Water quality of the watercourse, pond, or lake associated with the wetland.
4. Ratio of the number of occupied buildings within 500 feet of the wetland edge to the total area of the wetland (acres).

\section{I buildeng :3.5aerd}
2. More than 50 percent
b. From 25 to 50 percent
1.0
c. Less than 25 percent
0.5
0.1

a. Agriculture, forestry, or $\quad 1.0$ similar open space zoning

b. Rural residential

c. Commerciavindustrial, high density residential

a. High: Minimal pollution. $\quad 1.0$ Actual water quality meets or exceeds Class A or B standards

b. Medium: Moderate pollution. Actual water quality is below Class B standards

a. Less than 1 bldg: 10 acres $(<0.10)$

b. From 1 blog: 10 acres to 1 bldg: 2 acres $(0.10$. 0.50 )

c. More than 1 bldg: 2 acres (>0.5)

a. Less than 10 percent filled.

$$
\begin{aligned}
& 6.7 \text { acres impauted } \\
& 1.9+1.3 * 3.5 \text { acres created }
\end{aligned}
$$

b. From 10 to 50 percent c. More than 50 percent

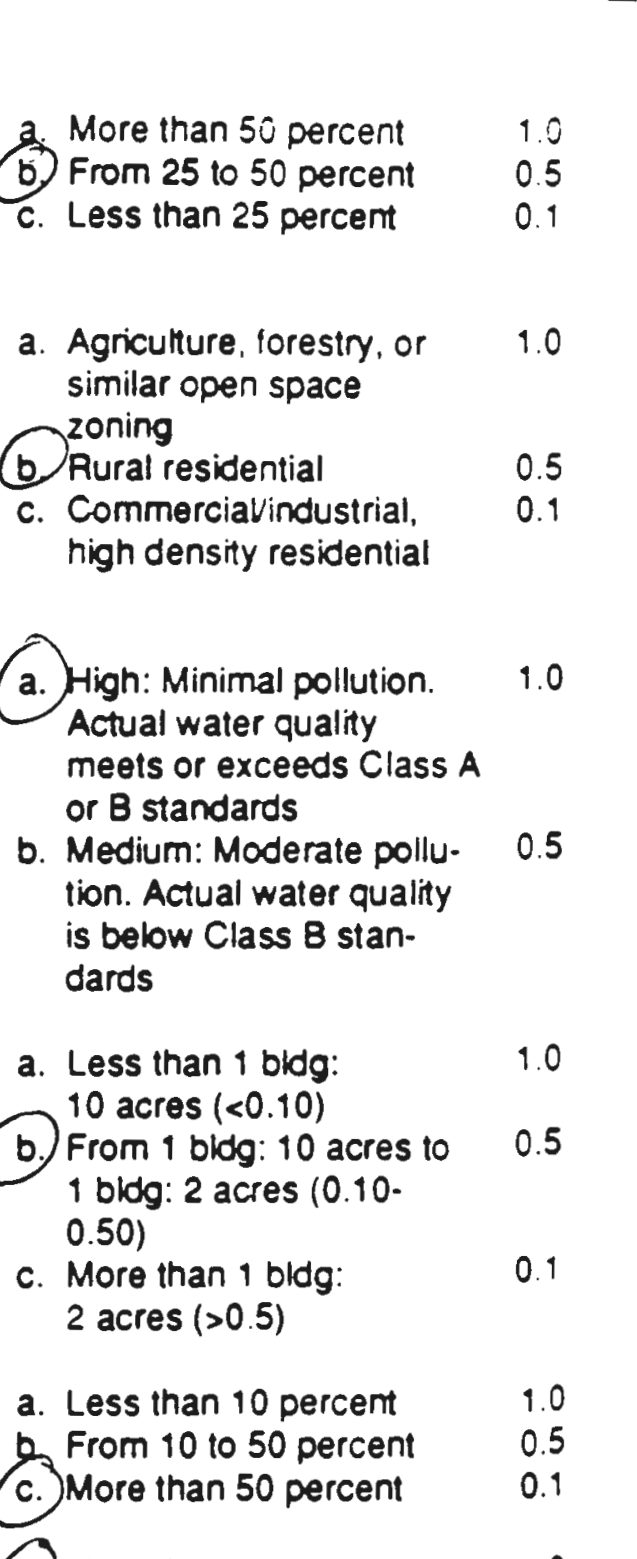

6. Percent of wetland edge bordered by a butfer of woodland or idle land at least 500 feet in width.

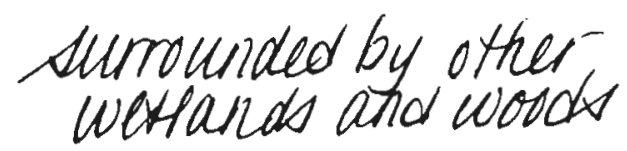

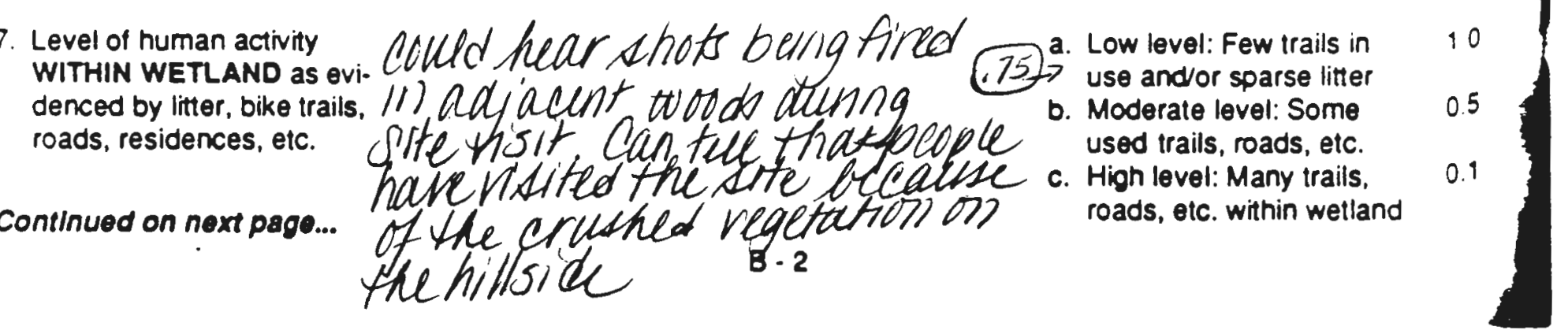




\begin{tabular}{cccc}
\hline A & $B$ & C & E \\
Evaluation & Computations & Evaluation & Functional Valu \\
Questions & or Actual Value & Criteria & index (FV)) \\
\hline
\end{tabular}

\section{QUESTIONS TO ANSWER IN THE FIELD (continued):}

8. Level of human activity IN UPLAND within 500 feet of the wetland edge as evi denced by litter, bike trails, roads, residences, elc.

9. Percent of wetland plant community presently being attered by mowing, grazing. larming, or other activity. (Include areas now dominated by phragmites or purple bosestrite).

10. Percent of wetland actively being drained for agriculture or other purposes.

11. Number of public road andror railroad crossings per 500 feet of wetland (measured along long axis of wetland).

12. Long-term stability.

$$
\begin{aligned}
& \text { lugh banking surnounding, howeves } \\
& \text { Liv sievation und surrounating } \\
& \text { wetlands gire eviden ce that } x \text { wettan of }
\end{aligned}
$$$$
\text { none detectled }
$$$$
\begin{aligned}
& \text { highway to west } \\
& \text { road to north }
\end{aligned}
$$

a. Low level: Few trails in use 1.0 andyor sparse litter

b. Moderate level: Some Irails, $\quad 0.5$ scattered residences, elc.

c. High level: Many trails, roads, etc. within upland

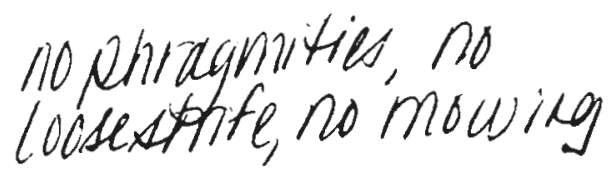

2. Less than 10 percem

b. From 10 to 50 percent

c. More than 50 percent (a) Less than 10 percemt 1.0

b. From 10 to 50 percent

c. More than 50 percent

b. One or fewer

c. Two or more

a. Wetland appears to be naturally occurring, not $\rightarrow$ impounded by dam or dike

b. Wetland appears to be somewhat dependent on artificial diking by dam, road, fill, etc.

AVERAGE FVI FOR FUNCTIONAL VALUE $1=$ Average of column D $=.758 \cdot(9.1 \div 12)$

EVALUATION AREA FOR FUNCTIONAL VALUE 1 = Tolal area of welland = acres. 
- USGS topographic map

- Land use map and/or recent aerial photographs

- Ruler or scale

- A method to calculate area (Dot grid, planimeter, etc.)

- N.H. Water Quality Report to Congress 305(b)

\begin{tabular}{cccc}
\hline A & B & C & C \\
Evaluation & Computations & Evaluation & Functional Valu \\
Questions & or Actual Value & Criteria & Index (FVI) \\
\hline
\end{tabular}

\section{QUESTIONS TO ANSWER IN THE OFFICE:}

1. Ecological integrity.

2. Area of shallow permanent open water (less than 6 feet deep) including streams in or adjacent to wetland.
Average FVI from Functional Value 1

.758

2. More than 3 acres

6. From 0.5 to 3 acres

t. Less than 0.5 acre

\section{QUESTIONS TO ANSWER IN THE FIELD:}

3. Water quality of the watercourse, wetland.

4. Wetland diversity.

$$
\text { S5, EM }
$$

5. Dominamt wetland class.

6. Interspersion of vegetation classes and/or open water. a. Three or more wetland classes present b. Two wetland classes present 0.5

c. One wetland class presem

(a.) Emergent marsh andvor shallow $\quad 1.0$ open water

b. Forested andyor scrub-shrub wetland 0.5

c. Scrub-shnub saturated (bog) or wet meadow

a. At least two wetland classes highly 1.0 interspersed. Areas of each class scattered within wetland like a patchwork quilt

b. Moderate interspersion of wetland 0.5 classes

c. Low degree of interspersion. Each wetland class is more or less contiguous and separate from the other classes 


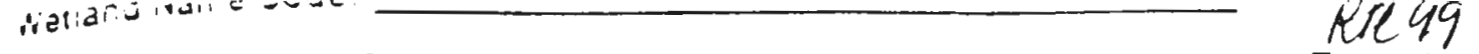

NEEDED FOR THIS EVALUATION:

Functional value 2

WETLAND WIL DLIFE HABITA (continued)

\begin{tabular}{cccc} 
A & 8 & $C$ & $D$ \\
$\begin{array}{c}\text { Evaluation } \\
\text { Questions }\end{array}$ & $\begin{array}{c}\text { Compurations } \\
\text { or Actual Value }\end{array}$ & $\begin{array}{c}\text { Evaluation } \\
\text { Criteria }\end{array}$ & $\begin{array}{c}\text { Functional Value } \\
\text { Index (FVi) }\end{array}$ \\
\hline
\end{tabular}

7. Wetland juxtaposition.

$$
\begin{aligned}
& \text { adjout wet lands, also } \\
& \text { comnected by periennial } \\
& \text { strean, sue mitigatiou } \\
& \text { map }
\end{aligned}
$$

8. Number of islands or inclusions of upland within wetland.

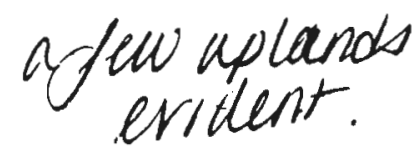

9. Wildlife access to other wetlands (overtand). Travel lanes should be 50-100 feet wide.

10. Percent of wetland edgo bordered by upland wildife habitat (bnush, woodland. active farmland, or idle land) at least 500 feet in width. a. Welland connected to other 1.0 wetlands within a 1 mile radius by perennial stream or lake

b. Wetland connected to other wetlands within a 1 10 3 mile radius by perennial stream or lake, OR other unconnected wetlands are present within a 1 mile radius

c. Wetland not hydrologically connected to other wellands within 3 miles and no other unconnected wetlands within 1 mile
a. Two or more
1.0
b. One
0.5
c. None
0.1

a.) $F$

Free access abong well

1.0 woodland, or lakeshore

b. Access partially blocked by roads, urtan areas, or other obstructions

c. Access blocked by roads, urban areas, or other obstruc. tions

a. More than 40 percent
b. From 10 to 40 percen

c. Less than 10 percent AVERAGE FVI FOR FUNCTIONAL VALUE $2=$ Average of column D $=.876 .(1.758: 10)$
EVALUATION AREA FOR FUNCTIONAL VALUE 2 = Tolal area of wetland $=3.5$ acres. 


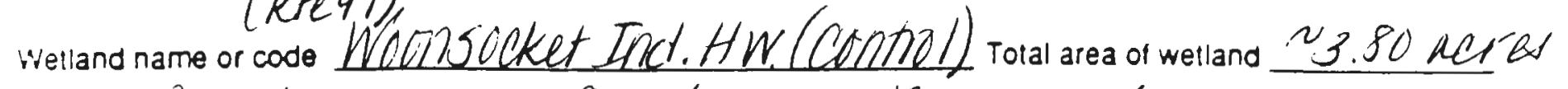

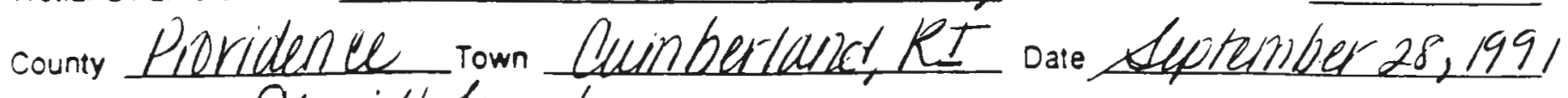
irvesigianorss Stacitoleomibe

\begin{tabular}{|c|c|c|c|}
\hline $\begin{array}{c}\text { A } \\
\text { Functlonal } \\
\text { Value }\end{array}$ & $\begin{array}{c}\text { B } \\
\text { FVI From } \\
\text { Data Sheets }\end{array}$ & $\begin{array}{c}\text { C } \\
\text { Slze of Evaluation } \\
\text { Area (Acres) }\end{array}$ & $\begin{array}{c}\text { D } \\
\text { Wetland Value Units } \\
B \times C\end{array}$ \\
\hline 1. Ecological Integrity & .883 & 3.80 & 3.355 \\
\hline 2. Wildlife Habitat & .618 & 3.80 & 2.348 \\
\hline $\begin{array}{l}\text { 3. Finfish Habitat: } \\
\text { Part A - Rivers and Streams }\end{array}$ & & & 5.703 \\
\hline Part $B$ - Ponds and Lakes & & & \\
\hline
\end{tabular}

\section{Educational Potential}

5. VisuaVAesthetic Quality

\section{Water Based Recreation}

\section{Flood Control Potential}

8. Ground Water Use Potential

\section{Sediment Trapping}

10. Nutriem Attenuation

11. Shoreline Anchoring and Dissipation of Erosive Forces

12. Urban Quality of Life
B: Wildlife Habitat
C: Educational Opportunity
D: VisuaVAesthetic Quality
E: Water Based Recreation

13. Historical Site Potential

14. Noteworthiness 
(lff Pino kiad)

NEEDED FOR THIS EVALUATION:

- Zoning mã

- SCS soils map

- N.H. Water Quality Report to Congress 305(b)

- USGS topographic map or recent aerial pholograph

- A method to calculate area (Dot grid, planimeter, etc.)

- Ruler or scale

- Map wheel (Optional)

\begin{tabular}{cccc}
\hline$A$ & $B$ & $C$ & $D$ \\
Evaluation & Computations & Evaluation & Functional Va: \\
Questions & or Actual Value & Criteria & index: FV! \\
\hline
\end{tabular}

\section{QUESTIONS TO ANSWER IN THE OFFICE:}

1. Percent of wetland having very poorly drained soils or Hydric A soils and/or open water.

2. Dominant land use zoning of wetland (see town zoning map). Use current land use if ditferent from what is zoned.

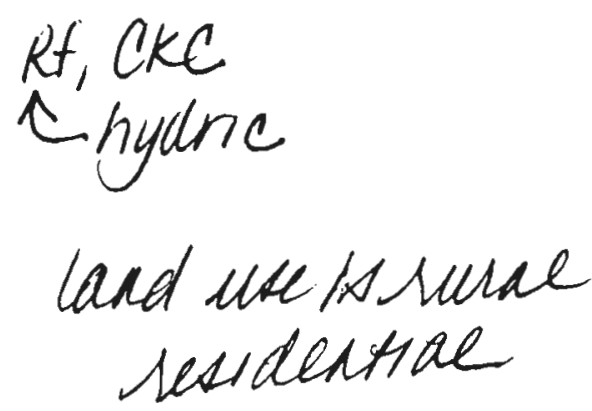

QUESTIONS TO ANSWER IN THE FIELD:

3. Water quality of the watercourse, pond, or lake associated with the wetland.

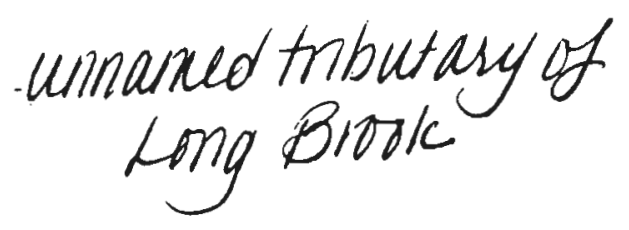

4. Ratio of the number of occupied buildings within 500 feet of the wetland edge to the total area of the wetland (acres).

5. Percent of original wettand filled.

lehouses: 3.8 acres

6. Percent of wetland edge bordered by a butfer of woodland or idle land at least 500 feet in width.

7. Level of human activity WITHIN WETLAND as evidenced by litter, bike trails, roads, residences, etc.
a. More than 50 percent
1.0
b. From 25 to 50 percent 0.5
c. Less than 25 percent
0.1

a. Agriculture, forestry, or 1.0 similar open space zoning

b. Rural residential $\quad 0.5$

c. Commerciavindustrial, high density residential

a. High: Minimal pollution. 1.0 Actual water quality meets or exceeds Class A or B standards

b. Medium: Moderate pollution. Actual water quality is below Class B standards

a. Less than 1 bldg: 10 acres $(<0.10)$

b. From 1 bldg: 10 acres to 1 bldg: 2 acres 10.10 0.50 )

c. More than 1 bldg: 2 acres $(>0.5)$

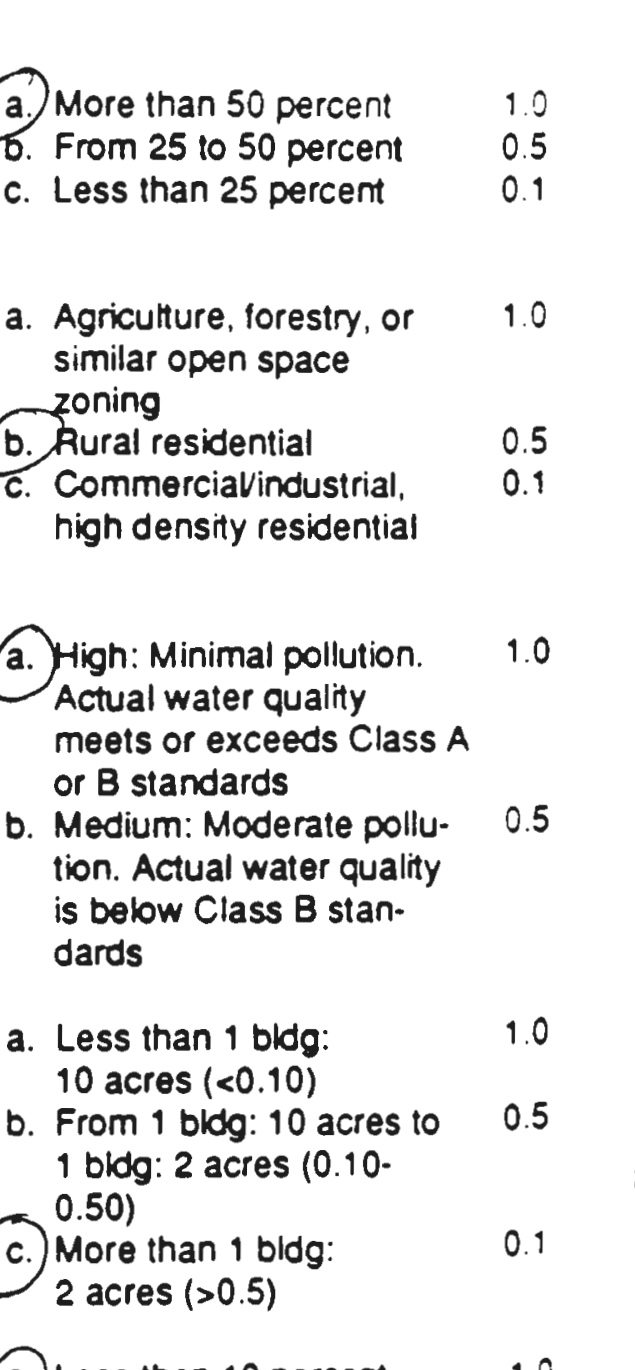
a. Less than 10 percent
b. From 10 to 50 percent
c. More than 50 percent
2. More than 80 percent
b. From 20 to 80 percent
c. Less than 20 percent

a. Low level: Few trails in 1.0 use and/or sparse litter

b. Moderate level: Some used trails, roads, etc.

c. High level: Many trails, roads, etc. within wetland 
(continued)

\begin{tabular}{cccc}
\hline A & $B$ & $C$ & $D$ \\
Evaluation & Computations & Evaluation & Functional Valt \\
Questions & or Actual Value & Criteria & Index (FVI) \\
\hline
\end{tabular}

QUESTIONS TO ANSWER IN THE FIELD (continued):

8. Level of human activity IN UPLAND within 500 feet of the wetland edge as evi denced by litter, bike trails. roads, residences, etc.

9. Percent of wetland plant community presently being attered by mowing, grazing. farming, or other activity. (Include areas now dominated by phragmites or purple bosestrife).

10. Percent of wetland actively being drained for agriculture or other purposes.

11. Number of public road and/or railroad crossings per 500 feet of wetland (measured along long axis of wetland).

12. Long-term stability.
a. Low level: Few trails in use 1.0 and/or sparse litter
b. Moderate level: Some trails, 0.5 scattered residences, etc.
c. High level: Many trails, roads, etc. within upland

$\begin{array}{ll}\text { a. Less than } 10 \text { percent } & 1.0 \\ \text { b. From } 10 \text { to } 50 \text { percent } & 0.5 \\ \text { c. More than } 50 \text { percent } & 0.1\end{array}$
a. None
b. One or fewer
c. Two or more
1.0
05
0.1
a. Wetland appears 10 be naturally occurring, not impounded by dam or dike
b. Wetland appears to be somewhat dependent on antificial diking by dam. road, fill, etc.

AVERAGE FVI FOR FUNCTIONAL VALUE $1=$ Average of column $0=.883 \cdot(10.6 \div 12)$

EVALUATION AREA FOR FUNCTIONAL VALUE $1=$ Tolal area of wetland $=5.80$ acres. 


\section{NEEDED FOR THIS EVALUATION:}

- USGS topographic map

- Land use map and/or recent aerial photographs

- Ruler or scalo

- A method to calculate area (Dol grid, planimeter, etc.)

- N.H. Water Quality Report to Congress 305(b)
Rte 49 (contiol)

\begin{tabular}{cccc}
\hline A & $\mathbf{B}$ & $\mathbf{C}$ & $\mathrm{D}$ \\
$\begin{array}{c}\text { Evaluation } \\
\text { Questions }\end{array}$ & $\begin{array}{c}\text { Computations } \\
\text { or Actual Value }\end{array}$ & $\begin{array}{c}\text { Evaluation } \\
\text { Criteria }\end{array}$ & $\begin{array}{c}\text { Functional Valu } \\
\text { Index (FVI) }\end{array}$ \\
\hline
\end{tabular}

\section{QUESTIONS TO ANSWER IN THE OFFICE:}

1. Ecological integrity.

Average FVI from Functional Value 1

.883

2. Area of shallow permanent open water (less than 6 feet

deep) including streams

in or adjacent to wetland.

a. More than 3 acres

b. From 0.5 to 3 acres

c. Less than 0.5 acre

1.0

0.5

0.1

\section{QUESTIONS TO ANSWER IN THE FIELD:}

3. Water quality of the watercourse,

FVI from Question V.1.3

lake, or pond associated with the wetland.

4. Wetland diversity.

a. Three or more welland classes present

b. Two wetland classes present

c. One wetland class present

5. Dominant wetland class.

a. Emergent marsh and/or shallow open water

b. Forested and/or scrub-shrub welland

c. Scrub-shrub saturated (bog) or wel meadow

6. Interspersion of vegetation classes andyor open water.

a. At least two wetland classes highly interspersed. Areas of each class scattered within wetland like a patchwork quitt

b. Moderate interspersion of welland classes

. Low degree of interspersion. Each wetland class is more or less con. tiguous and separate from the other classes 


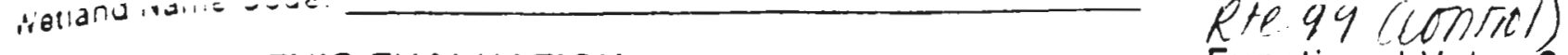

NEEDED FOR THIS EVALUATION:

Functional value 2

WETLAND WILDLIFE HABITAT (continued)

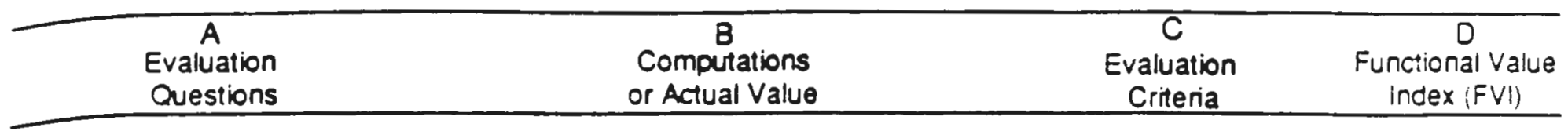

7. Wetland juxtaposition.

a.)

Welland connected to other $\quad 1.0$ wetlands within a 1 mile radius by perennial stream or lake

b. Wetland connected to other wetlands within a 1 to 3 mile radius by perennial stream or lake, OR other unconnected wetlands are present within a 1 mile radius

c. Wetland not hydrologically connected to other wetlands within 3 miles and no other unconnected wetlands within 1 mile

8. Number of islands or inclu-

a. Two or more sions of upland within wetland.

b. One

9. Wildlife access to other wetlands (overland). Travel lanes should be 50-100 feet wide.
a. Free access abng well $\quad 1.0$ vegetated stream corridor, woodland, or lakeshore
b. Access partially blocked by roads, urban areas, or other obstructions
c. Access blocked by roads. urban areas, or other obstruc. tions

10. Percent of welland edge bordered by upland wildte habitat (brush, woodland, active farmland, or idle land) at least $\mathbf{5 0 0}$ feet in widh.

AVERAGE FVI FOR FUNCTIONAL VALUE $2=$ Average of column $0=.618 \cdot(6.183 \div 10)$ EVALUATION AREA FOR FUNCTIONAL VALUE $2=$ Total area of wetland $=3.8$ acres. 
wetland name or code Arthur Nemlen

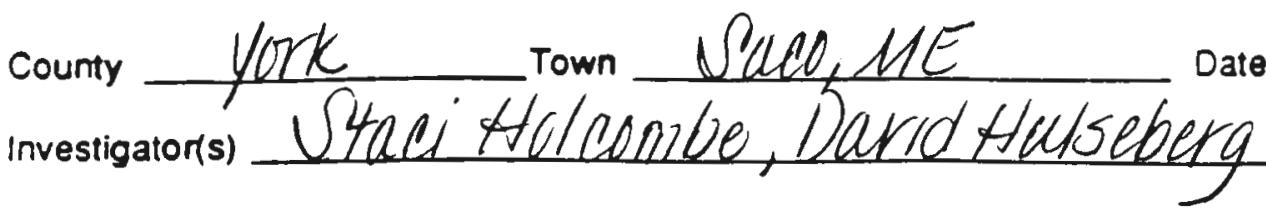
Total area of wetland.5 Leles

\begin{tabular}{cc}
\hline Aunctlonal & B \\
Value & FVI From \\
\hline
\end{tabular}

\section{Slze of Evaluation \\ Area (Acres)}

D

1. Ecological Integrity

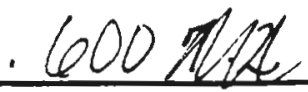

.5

Wetland Value Units $\mathrm{B} \times \mathrm{C}$

2. Wildlife Habitat .300

.5 300

3. Finfish Habitat:

Pant A - Rivers and Streams

Pan $B$ - Ponds and Lakes

4. Educational Potential

5. VisuaVAesthetic Quality

\section{Water Based Recreation}

7. Flood Control Potential

8. Ground Water Use Potential

9. Sediment Trapping

10. Nutrient Attenuation

11. Shoreline Anchoring and

Dissipation of Erosive Forces

12. Urban Quality of Life

B: Wildlifo Habitat

C: Educational Opportunity

D: VisuaVAesthetic Quality

E: Water Based Recreation

13. Historical Site Potential

14. Noteworthiness 
NEEDED FOR THIS EVALUATION:

- Zoning mấ

- SCS soils map

- N.H. Water Quality Report to Congress 305(b)

- USGS topographic map or recent aerial photograph

- A method to calculate area (Dot grid, planimeter, etc.)

- Ruler or scale

- Map wheel (Optional)

\section{A}

Evaluation

Questions
Functional Value 1 ECOLOGICAL INTEGRITY

\section{QUESTIONS TO ANSWER IN THE OFFICE:}

1. Percent of wetland having very poorly drained soils or Hydric A soils andror open water.

2. Dominant land use zoning of welland (see town zoning map). Use current land use if different from what is zoned.

\section{QUESTIONS TO ANSWER IN THE FIELD:}

3. Water quality of the watercourse, pond, or lake associated with the wetland.

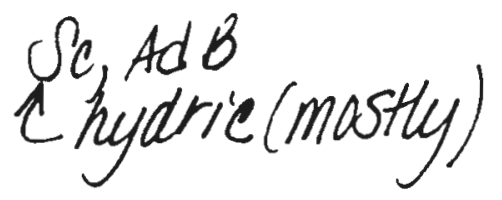

$k 1+(10 n e)$
Evaluation Criteria
Functional Valu Index (FVI)
1.0

0.5

0.1 similar open space zoning

b. Aural residential

c. CommerciaVindustrial. high density residential

a. High: Minimal pollution. $\quad 1.0$ Actual water quality meets or exceeds Class A or $\mathbf{B}$ standards

b. Medium: Moderate pollution. Actual water quality is below Class B standards

a. Less than $1 \mathrm{bldg}$ : 10 acres (<0.10)

b. From 1 bldg: 10 acres to 1 bldg: 2 acres 10.10 $0.50)$

c. More than 1 bldg: 2 acres ( $>0.5$ )

a. Less than 10 percent

c. More than 50 percent

a. More than 80 percent

b. From 20 to 80 percent

c. Less than 20 percent

bordered by a butter of woodland or idle land at least 500 feet in width.

a. Low level: Few trails in use andror sparse litter WITHIN WETLAND as evidenced by litter, bike trails. roads, residences, etc.

b. Moderate level: Some used trails, roads, etc.

c. High level: Many trails. 


\begin{tabular}{cccc}
\hline$A$ & $B$ & $C$ & 0 \\
Evaluation & Computations & Evaluation & Functional Vatl \\
Questions & or Actual Value & Criteria & Index (FVi) \\
\hline
\end{tabular}

QUESTIONS TO ANSWER IN THE FIELD (continued):

8. Level of human activity IN UPLAND within 500 feet of the wetland edge as evi 2 roads guite a few
residences but not guite
as in intense as others denced by litter, bike trails, roads, residences, etc.

9. Percent of welland plant community presently being altered by mowing, grazing, farming, or other activity. (Include areas now dominated by phragmites or purple loosestrife).

10. Percent of wetland actively being drained for agriculture or other purposes.

11. Number of public road and/or railroad crossings per 500 feet of wetland (measured along long axis of wetland).

12. Long-term stability. a. Low level: Few trails in use 1.0 and/or sparse litter

b. Moderate level: Some trails, 0.5

$\rightarrow$ scattered residences, elc.

c. High level: Many trails, roads, etc. within upland

a. Less than 10 percent 1.0

b. From 10 to 50 percent 0.5

c. More than 50 percent a. Less than 10 percem $\quad 10$

b. From 101050 percent 05

c. More than 50 percent 0.1

2 yearallel

a. None

b. One or fewer

c. Two or more

1.0

0.5

0.1

a. Wetland appears to be 10 naturally occurring, not impounded by dam or dike

b. Wetland appears to be somewhat dependent on artificial diking by dam. road, fill, etc.

AVERAGE FVI FOR FUNCTIONAL VALUE $1=$ Average of column $0=(1.20 \div 12), 600$

EVALUATION AREA FOR FUNCTIONAL VALUE $1=$ Total area of wetland $=15$ acres. 
- USGS lopographic map

- Land use map andjor recent aerial photographs

- Ruler or scale

- A method to calculate area (Dot grid, planimeter, etc.)

- N.H. Water Quality Report to Congress 305(b)

\begin{tabular}{|c|c|c|c|}
\hline $\begin{array}{c}\text { A } \\
\text { Evaluation } \\
\text { Questions }\end{array}$ & $\begin{array}{c}8 \\
\text { Computations } \\
\text { or Actual Value }\end{array}$ & $\begin{array}{c}\text { C } \\
\text { Evaluation } \\
\text { Criteria } \\
\end{array}$ & $\begin{array}{c}\text { D } \\
\text { Functional Valu } \\
\text { Index (FVI) }\end{array}$ \\
\hline
\end{tabular}

\section{QUESTIONS TO ANSWER IN THE OFFICE:}

1. Ecological integrity.

2. Area of shallow permanent open water (less than 6 feet deep) including streams in or adjacent to wetland.
Average FVI from Functional Value 1

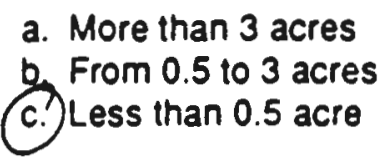

1.0

0.5

0.1

\section{QUESTIONS TO ANSWER IN THE FIELD:}

3. Water quality of the watercourse,

FVI from Question V.1.3 lake, or pond associated with the wetland.

4. Wetland diversity.

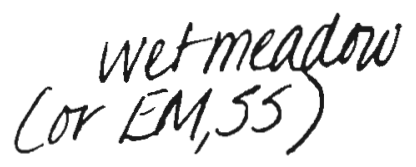

a. Three or more wetland classes present

b. Two wetland classes present

c. One wetland class present

5. Dominant wetland class.

a. Emergent marsh and/or shallow open water

b Forested and/or scrub-shnub wetland 0.5

c. scrub-shnub saturated (bog) or wet meadow

6. Interspersion of vegetation classes and/or open water.

a. At least two wetland classes highly interspersed. Areas of each class scattered within wetland like a patchwork quilt

b. Moderate interspersion of wetland classes

c. Low degree of interspersion. Each wetland class is more or less contiguous and separate from the other classes 
vietland

NEEDED FOR THIS EVALUATION:

Functional value 2

WETLAND WILDLIFE HABITA (continued)

\begin{tabular}{cccc}
\hline A & Bvaluation & $C$ & Com \\
Questions & $\begin{array}{c}\text { Computations } \\
\text { or Actual Value }\end{array}$ & $\begin{array}{c}\text { Evaluation } \\
\text { Criteria }\end{array}$ & $\begin{array}{c}\text { Functional Value } \\
\text { Index (FVI) }\end{array}$ \\
\hline
\end{tabular}

7. Wetland juxtaposition.

8. Number of islands or inclusions of upland within welland. lanes should be 50-100 feet wide. a. Two or more

a. Wetland connected to other wetlands within a 1 mile radius by perennial stream or lake

b. Wetland connected to other wetlands within a 1 to 3 mile radius by perennial stream or lake, OR other unconnected wetlands are present within a 1 mile radius

c. Wetland not hydrologically connected to other wetlands within 3 miles and no other unconnected wetlands within 1 mile

b. One

c. None

a. Free access abng well vegetated stream $\infty$ midor. woodland, or lakeshore roads, urban areas, or other obstructions

c. Access blocked by roads, urban areas, or other obstruc. tions

a. More than 40 percent

b. From 10 to 40 percent

c. Less than 10 percem

0.5

0.1 habitat (brush, woodland, active farmland, or idle land) at least 500 feet in widh.

$50^{\prime}$ decp, adjacent

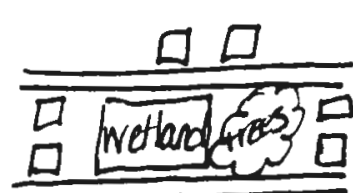

Oakiand Rd

AVERAGE FVI FOR FUNCTIONAL VALUE $2=$ Average of column $0=1300(3 \div 10)$

EVALUATION AREA FOR FUNCTIONAL VALUE 2 - Total area of welland =

15 acres. 


\section{SUMMARY SHEET FOR THE N.H. METHOD}

wetland name or code Arthur Nemon (Control) _otal area or wetland 1.75 aeres county $\frac{\text { Yonk }}{\text { Investigator(s) Staci Hol combe, Darid Hus Seberg }}$

\begin{tabular}{|c|c|c|c|}
\hline $\begin{array}{c}\text { A } \\
\text { Functlonal } \\
\text { Value }\end{array}$ & $\begin{array}{c}\text { B } \\
\text { Fvi From } \\
\text { Data Shoots }\end{array}$ & $\begin{array}{c}\text { C } \\
\text { Slzo of Evaluation } \\
\text { Area (Acres) }\end{array}$ & $\begin{array}{c}D \\
\text { Wetland Value Units } \\
B \times C\end{array}$ \\
\hline 1. Ecological Integrity & .125 & 75 & 544 \\
\hline 2. Wilditite Habitat & 643 & 75 & 482 \\
\hline $\begin{array}{l}\text { 3. Fintish Habitat: } \\
\text { Part A - Rivers and Streams }\end{array}$ & & & 1.026 \\
\hline
\end{tabular}

4. Educational Potential

5. VisuaVAesthetic Quality

6. Water Based Recreation

7. Flood Control Potential

8. Ground Water Use Potential

9. Sediment Trapping

10. Nutrient Attenuation

11. Shoreline Anchoring and

Dissipation of Erosive Forces

12. Urban Quality of Life
B: Wildife Habitat
C: Educational Opportunity
$D$ : Visual/Aesthetic Quality
E: Water Based Recreation

\section{Historical Site Potential}

14. Noteworthiness 
(ut ptes 112+95)

\section{NEEDED FOR THIS EVALUATION:}

- Zoning mẫ

- SCS soils map

- N.H. Water Quality Report to Congress 305(b)

- USGS topographic map or recent aerial photograph

- A method to calculate arga (Dot grid, planimeter, etc.)

- Ruler or scale

- Map wheel (Optional)

Split into

(EM+/SS site)

\section{A}

Evaluation

Questions
Computations

or Actual Value

\section{QUESTIONS TO ANSWER IN THE OFFICE:}

1. Percent of wetland having very poorly drained soils or Hydric A soils and/or open water.

2. Dominant land use zoning of wetland (see town zoning map). Use current land use if different from what is zoned.

\section{QUESTIONS TO ANSWER IN THE FIELD:}

3. Water quality of the watercourse, pond, or lake associated with the wetland.

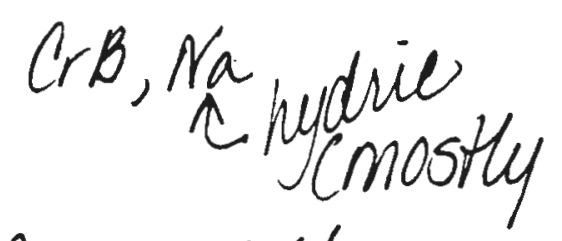

Commerciall Industrial h. Rural residential $\quad 0.5$

b. From 1 bldg: 10 acres to 0.5

2 lowilding: $2,75 a c$ occupied buildings within
500 feet of the wetland edge to the total area of the wetland (acres).

5. Percent of original wetland filled.

6. Percent of wetland edge bordered by a butter of woodland or idle land at least 500 feet in width.

7. Level of human activity WITHIN WETLAND as evidenced by litter, bike trails. roads, residences, etc.

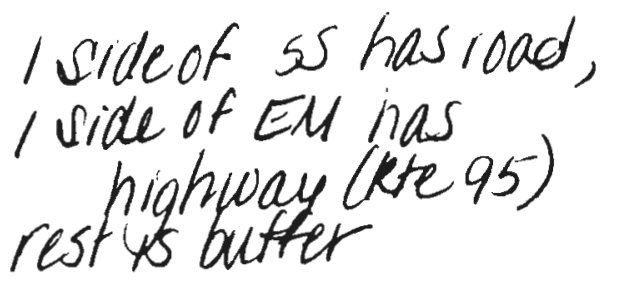

Functional Value 1

ECOLOGICAL INTEGRITY
Evaluation

Criteria
Functional Vah Index (FVI) a. More than 50 percent $\quad 1.0$

b. From 25 to 50 percent 0.5

c. Less than 25 percent 0.1

a. Agriculture, forestry, or $\quad 1.0$ similar open space zoning

c. CommerciaVindustrial, $\quad 0.1$ high density residential a. High: Minimal pollution. $\quad 1.0$
Actual water quality meets or exceeds Class $A$ or B standards

b. Medium: Moderate pollution. Actual water quality is below Class B standards

a. Less than 1 bldg: 10 acres $(<0.10)$ 1 bldg: 2 acres $(0.10$. 0.50 )

C. More than 1 bidg: 2 acres (>0.5)

$\begin{array}{ll}\text { a. Less than } 10 \text { percent } & 1.0 \\ \text { o. From } 10 \text { to } 50 \text { percent } & 0.5 \\ \text { c. More than } 50 \text { percent } & 0.1\end{array}$

More than 80 percent 10

b. From 20 to 80 percent 0.5

c. Less than 20 percent 0.1 
A

Evaluation

Questions
Computations

or Actual Value
C

Evaluation

Criteria
Functional Vai Index (FVI)

QUESTIONS TO ANSWER IN THE FIELD (continued):

8. Level of human activity IN UPLAND within 500 feet of the wetland edge as evi denced by litter, bike trails. roads, residences, etc.

9. Percent of wetland plant community presently being attered by mowing, grazing. farming, or other activity. (Include areas now dominated by phragmites or purple bosestrife).

10. Percent of welland actively being drained for agriculture or other purposes.

11. Number of public road andror railroad crossings per 500 leet of wetland (measured along long axis of wetland).

12. Long-term stability.

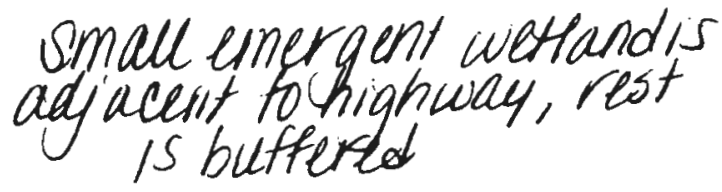

a. Low level: Few trails in use andjor sparse litter

b. Moderate level: Some trails, $\quad 0.5$ scattered residences, elc.

c. High level: Many trails, roads, otc. within upland

a. Less than 10 percent

b. From 10 to 50 percent

c. More than 50 percent

1.0

0.5

0.1 a. Less than 10 percent 1.0

b. From 101050 percent $\quad 0.5$

c. More than 50 percent 0.1

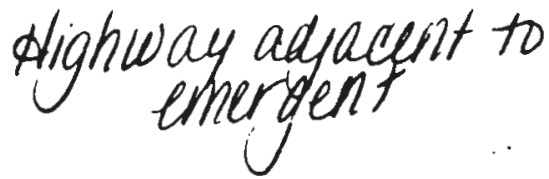

1.0

0.5

0.1

c. Two or more

a. Wetland appears to be naturałly occurring, not impounded by dam or dike

b. Wetland appears to be somewhat dependent on artificial diking by dam, road, fill, etc.

AVERAGE FVI FOR FUNCTIONAL VALUE $1=$ AVerage of column D $=.725(8.7: 12)$

EVALUATION AREA FOR FUNCTIONAL VALUE $1=$ Total area of wetland $=., 75$ acres. 
הat!ar.d Nan.

NEEDED FOR THIS EVALUATION:

7. Wetland juxtaposition.

8. Number of islands or inclusions of upland within wetland.

a. Wetland connected to other wetlands within a 1 mile radius by perennial stream or lake

b. Wetland connected to other wetlands within a 1103 mile radius by perennial stream or lake, OR other unconnected wetlands are oresent withina 1 mile radius

c. Welland not hydrologically connected to other wellands within 3 miles and no other unconnected wetlands within 1 mile
a. Two or more
b. One
c. None

9. Wildlife access 10 other wetlands (overtand). Travel lanes should be 50-100 leet wide. surrounding large scrub shrublettind, also ample aceess from emergent area. a. Fre

Free access along well
vegetated stream corridor, woodland, or lakeshore

b. Access partially blocked by roads, urban areas, or other obstructions

c. Access blocked by roads, urban areas, or other obstruc. tions
10. Percent of wetland edge bordered by upland wild"te habitat (brush, woodland. active farmland, or idle land) at least 500 teet in width. a. More than 40 percent

takmg into consideration of. From 10 to 40 percent the size of the large

c. Less than 10 percent

AVERAGE FVI FOR FUNCTIONAL VALUE $2=$ Average of column D $=.643(1.425 \div 10)$ EVALUATION AREA FOR FUNCTIONAL VALUE 2 - Total area of wetland acres. 
NEEDED FOR THIS EVALUATION:

- JSGS topographic map

- Land use map and/or recent aerial photographs

- Ruler or scalo

- A method to calculate area (Dot grid, planimeter, etc.)

- N.H. Water Quality Repon 10 Congress 305(b)
Nemon(control)

Functional Value 2

WETLAND WILDLIFE HABITA.

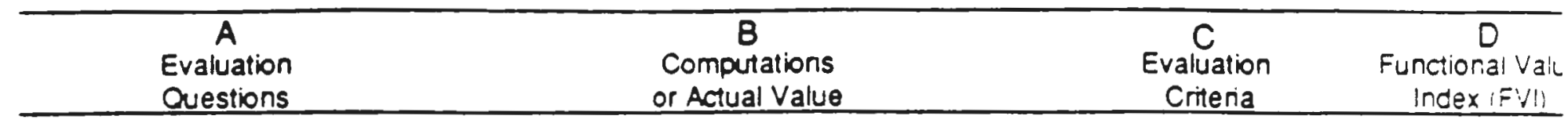

\section{QUESTIONS TO ANSWER IN THE OFFICE:}

1. Ecological imegrity.

2. Area of shallow permanent open water (less than 6 feet deep) including streams

in or adjacemt to wetland.
Average FVI from Functional Value 1

.125

a. More than 3 acres

From 0.5103 acres

Cess than 0.5 acre

\section{QUESTIONS TO ANSWER IN THE FIELD:}

3. Water quality of the watercourse,

FVI from Question V.1.3 lake, or pond associated with the wetland.

4. Welland diversity.

$$
\begin{aligned}
& \text { EM+Ss present, though } \\
& \text { not together; a separate } \\
& \text { sites }
\end{aligned}
$$

a. Three or more wetland classes presemt

b. Two wetland classes present

c. One wetland class present

5. Dominant wetland class.

$$
\begin{aligned}
& \text { Larger site was the } \\
& \text { scribs shurb site, adjacent } \\
& \text { to wondlands }
\end{aligned}
$$

a. Emergent marsh and/or shallow open water

b. Forested and/or scrub-shnub wetland

c. Scrub-shrub saturated (bog) or wet meadow

6. Interspersion of vegetation classes and/or open water.

$$
\text { 2. were separate }
$$

a. At least two wetland classes highly interspersed. Areas of each class scattered within wetland like a patchwork quilt

b. Moderate interspersion of wetland classes

c. Low degree of interspersion. Each tiguous and separate from the other classes 
SUMMARY SHEET FOR THE N.H. METHOD

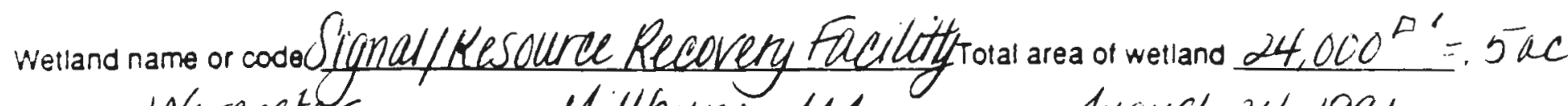
county Weresster Town Millbun, NA Dare August 24 , 1991

Investigator(s)

\begin{tabular}{|c|c|c|c|}
\hline $\begin{array}{l}\text { A } \\
\text { Functlonal } \\
\text { Value }\end{array}$ & $\begin{array}{c}\text { B } \\
\text { FVI From } \\
\text { Data Sheots }\end{array}$ & $\begin{array}{c}\text { C } \\
\text { Slze of Evaluation } \\
\text { Area (Acres) }\end{array}$ & $\begin{array}{c}D \\
\text { Wetland Value Untts } \\
B \times C\end{array}$ \\
\hline 1. Ecological Integrity & .500 & .5 & .250 \\
\hline 2. Wildife Habitat & .530 & & .265 \\
\hline \multirow{2}{*}{$\begin{array}{l}\text { 3. Finfish Habitat: } \\
\text { Part A - Rivers and Streams } \\
\text { Part B - Ponds and Lakes }\end{array}$} & & & . \\
\hline & & & \\
\hline
\end{tabular}

4. Educational Potential

5. VisuaVAesthetic Quality

6. Water Based Recreation

7. Flood Control Potential

8. Ground Water Use Potential

9. Sediment Trapping

10. Nutrient Attenuation

11. Shoreline Anchoring and

Dissipation of Erosive Forces

12. Urtan Quality of Life

B: Wildlite Habitat

C: Educational Opportunity

D: VisuaVAesthetic Quality

E: Water Based Recreation

13. Historical Site Potential

14. Noteworthiness 
NEEDED FOR THIS EVALUATION:

- Zoning mấ

- SCS soils map

- N.H. Water Quality Report to Congress 305(b)

- USGS topographic map or recent aerial photograph

- A method to calculate area (Dot grid, planimeter, etc.)

- Ruler or scale

- Map wheel (Optional)
A

Evaluation

Questions
Computations

or Actual Value ugnal / Kesto

Functional Value 1

ECOLOGICAL INTEGRITY

\section{QUESTIONS TO ANSWER IN THE OFFICE:}

1. Percent of wetland having very poorly drained soils or Hydric A soils and/or open water.

2. Dominant land use zoning of wetland (see town zoning map). Use curremt land use if different from what is zoned.

\section{QUESTIONS TO ANSWER IN THE FIELD:}

3. Water quality of the watercourse, pond, or lake associated with the welland.

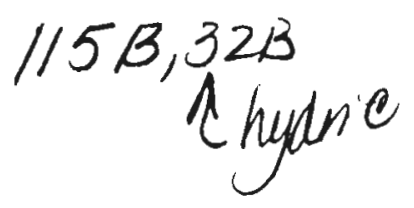

I2

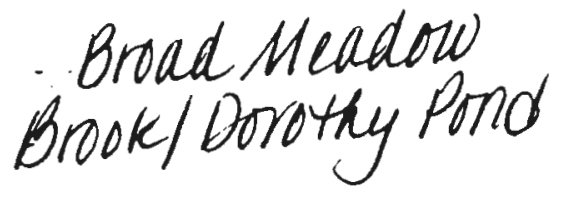

5 buildings: 5 acres
4. Ratio of the number of occupied buildings within 500 feet of the wetland edge to the total area of the welland (acres).
a. More than 50 percent 1.0
b. From 25 to 50 percent 0.5
c. Less than 25 percent 0.1
a. Agriculture, forestry, or $\quad 1.0$ similar open space zoning
b. Rural residential
c. CommerciaVindustrial, high density residential
a. High: Minimal pollution. $\quad 1.0$ Actual water quality meets or exceeds Class A or $\mathbf{8}$ standards
b. Medium: Moderate pollu- tion. Actual water quality is below Class B stan- dards

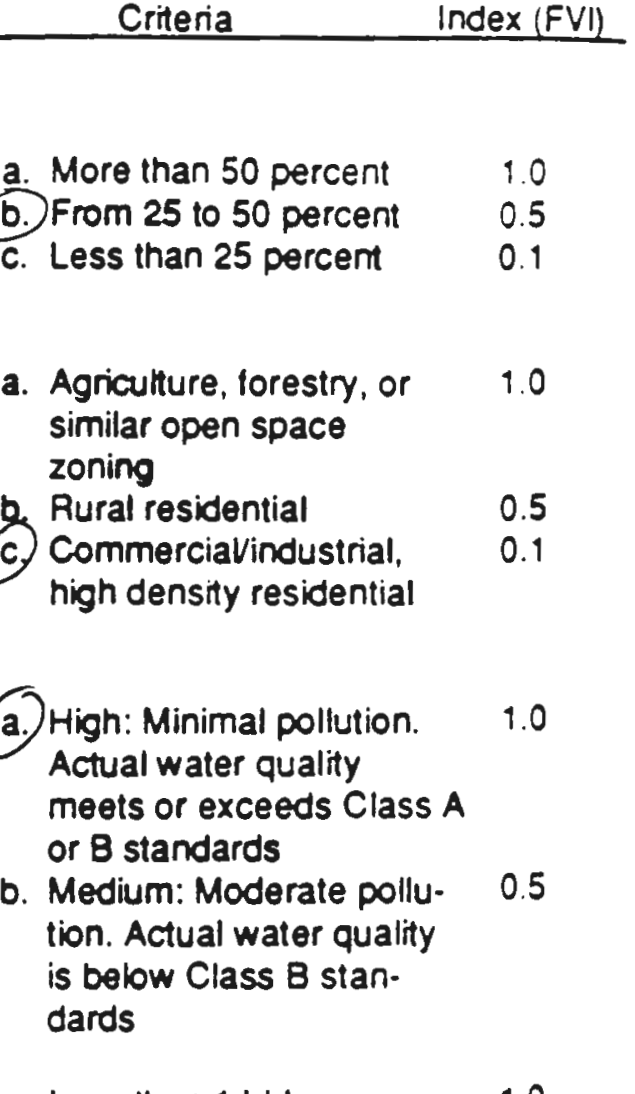
a. Less than 1 bldg:
10 acres $(<0.10)$
b. From 1 bldg: 10 acres to 1 bldg: 2 acres 10.10 . $0.50)$
c. More than 1 bldg: 2 acres ( $>0.5)$
a. Less than 10 percent $\quad 1.0$
b. From 10 to 50 percent 0.5
C. More than 50 percent
$\begin{array}{ll}\text { a. More than } 80 \text { percent } & 1.0 \\ \text { b. From } 20 \text { to } 80 \text { percent } & 0.5 \\ \text { c. Less than } 20 \text { percent } & 0.1\end{array}$

filled.

$$
\begin{aligned}
& \text { 21,500" destroyed; } \\
& \text { 25,000"created }
\end{aligned}
$$

6. Percent of welland edge bordered by a butfer of woodland or idle land at least 500 feet in width.

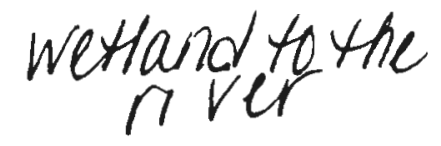

7. Level of human activity WITHIN WETLAND as evidenced by litter, bike trails, roads, residences, etc.

a. Low level: Fow trails in
use and/or sparse litter
b. Moderate level: Some
used trails, roads, etc.
c. High level: Many trails,
roads, etc. within wetland




$\begin{array}{cc}\text { A } & \text { B } \\ \text { Evaluation } & \text { Computations } \\ \text { Questions } & \text { or Actual Value }\end{array}$

\section{Evaluation} Criteria
Functional Valı
Index (FVI)

QUESTIONS TO ANSWER IN THE FIELD (continued):

8. Level of human activity iN UPLAND within 500 feet of the wetland edge as evi denced by litter, bike trails, roads, residences, etc.

$$
\begin{aligned}
& \text { Masspike, Rte } 20 \text {, and } \\
& \text { Faciluty cover } 3 \text { of the } 4 \\
& \text { sides of the wottand }
\end{aligned}
$$

a. Low level: Few trails in use and/or sparse litter

b. Moderate level: Some trails, 0.5 scattered residences, etc.

c. High level: Many trails, roads, etc. within upland

1.0 a. Less than 10 percent

b. From 10 to 50 percent

c. More than 50 percent attered by mowing, grazing. farming, or other activity. loosedtinte (Include areas now dominated by phragmites or purple bosestrife).

10. Percent of wetland actively being drained for agriculture or other purposes.
a. Less than 10 percent
b. From 10 to 50 percent
1.0
c. More than 50 percent
0.5

11. Number of public road and/or railroad crossings per 500 feet of wetland (measured along long axis of welland).

wees road arosses wetland

a. None and nuns pararell.

b. One or fewer thieam suem to make

(a.) Wetland appears to be naturally occurring, not impounded by dam or dike wettland stable

b. Welland appears to be somewhat dependent on antificial diking by dam. road, till, etc.

Ground sumedquite dry, even with all the rain in the aree expenen ced from "therricane Bub" $078 / 20 / 91$

AVERAGE FVI FOR FUNCTIONAL VALUE $1=$ Average of column D $=149.16 .12$

EVALUATION AREA FOR FUNCTIONAL VALUE 1 = Tolal area of wetland acres. 


\section{NEEDED FOR THIS EVALUATION:}

- USGS topographic map

- Land use map and/or recent aerial photographs

- Ruler or scale

- A method to calculate area (Dot grid, planimeter, eic.)

- N.H. Water Quality Report to Congress 305(b) signal / Kesco

\section{A}

Evaluation

Questions
C

Evaluation

Criteria

\section{QUESTIONS TO ANSWER IN THE OFFICE:}

1. Ecological integrity.

2. Area of shallow permanemt open water (less than 6 feet deep) including streams in or adjacem to welland.
Average FVI from Functional Value 1

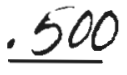
a. More than 3 acres
b. From 0.5 to 3 acres
c. Less than 0.5 acre

3. Water quality of the watercourse,

FVI from Question V.1.3 lake, or pond associated with the wetland.

4. Welland diversity.

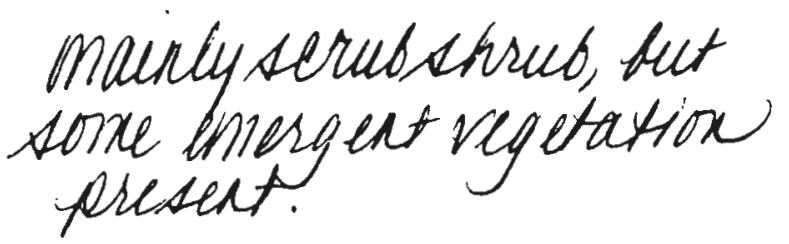

a. Three or more wetland classes present

b) Two wetland classes present

c. One wetland class present

5. Dominant wetland class.

a. Emergemt marsh and/or shallow open water

b. Forested andyor scrub-shrub wetland

c. Scrub-shnub saturated (bog) or wet meadow

6. Interspersion of vegetation classes andyor open water.

a. At least two wetland classes highly interspersed. Areas of each class scattered within wetland like a patchwork quitt

b. Moderate interspersion of wetland classes

c. Low degree of interspersion. Each welland class is more or less con. tiguous and separate from the other classes 
Netland Name Coce:

NEEDED FOR THIS EVALUATION:

Functional value 2

WETLAND WILDLIFE HABITAI (continued)

\begin{tabular}{cccc}
\hline A & B & $C$ & $D$ \\
$\begin{array}{c}\text { Evaluation } \\
\text { Questions }\end{array}$ & $\begin{array}{c}\text { Computations } \\
\text { or Actual Value }\end{array}$ & $\begin{array}{c}\text { Evaluation } \\
\text { Criteria }\end{array}$ & $\begin{array}{c}\text { Functional Value } \\
\text { Index (FVI) }\end{array}$ \\
\hline
\end{tabular}

7. Wetland juxtaposition.

$$
\begin{aligned}
& \text { cther wettands on } \\
& \text { Site of those conineted } \\
& \text { by the strean }
\end{aligned}
$$

a. Wetland connected to other 1.0 wetlands within a 1 mile radius by perennial stream or lake

b. Wetland connected to other wetlands within a 1 to 3 mile radius by perennial stream or lake, OR other unconnected wetlands are present within a 1 mile radius

c. Wetland not hydrologically connected to other wetlands within 3 miles and no other unconnected wetlands within 1 mile

a.) Two or more

b. One

c. None wetland. nigherpatohes of bush

a. Free access along well vegetated stream comidor. woodland, or lakeshore wetlands (overland). Trave lanes should be 50-100 feet wide.

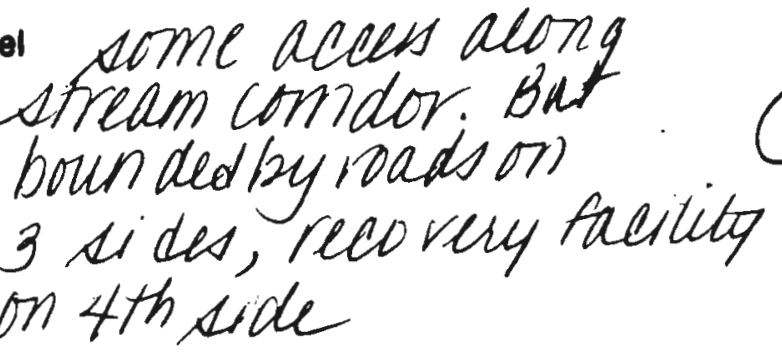

b.) Access partially blocked by roads, urban areas, or other obstructions

c. Access blocked by roads, urban areas, or other obstructions
10. Percent of wetland edge bordered by upland wileme habitat (brush, woodland, active farmland, or idle land) at least $\mathbf{5 0 0}$ feet in width.

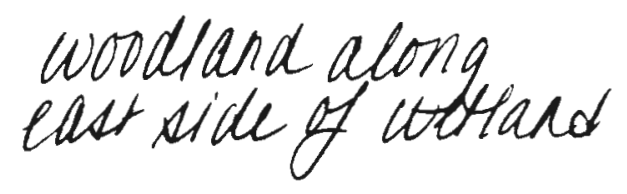

a. More than 40 percent

6. From 10 to 40 percent

c. Less than 10 percent
1.0

0.5

0.1

AVERAGE FVI FOR FUNCTIONAL VALUE 2 - Average of column D $=.530 \cdot(5.3 \div 10)$

EVALUATION AREA FOR FUNCTIONAL VALUE 2 = Total area of wetland = acres. 


\section{SUMMARY SHEET FOR THE N.H. METHOD}

Wetland name or code Uignal/ReSCD (Contolste) Total area of welland $2 /$ acre:

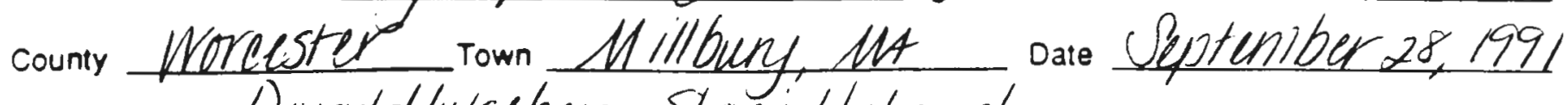
investigator(s) Deirid Atuklberg, Stact Hol combe.

\section{A}

Functional

Value

1. Ecological Integrity

2. Wildlife Habitat

B

FVI From

Data Sheots

.458

.6166

\section{Size of Evaluation}

Area (Acres)
D

Welland Value UnHs $B \times C$

\section{Fintish Habitat:}

Part A - Rivers and Streams .458

Part $B$ - Ponds and Lakes

\section{Educational Potential}

\section{VisuaVAesthetic Quality}

\section{Water Based Recreation}

\section{Flood Control Potential}

\section{Ground Water Use Potential}

9. Sediment Trapping

10. Nutrient Attenuation

11. Shoreline Anchoring and

Dissipation of Erosive Forces

12. Urban Quality of Lifo

8: Wildlife Habitat

C: Educational Opportunity

D: VisuaVAesthetic Quality

E: Water Based Recreation

13. Historical Site Potential

14. Noteworthiness 
NEEDED FOR THIS EVALUATION:

- Zoning mấ

- SCS soils map

- N.H. Water Quality Report to Congress 305(b)

- USGS topographic map or recent aerial pholograph

- A method to calculate area (Dot grid, planimeter, etc.)

- Ruler or scale

- Map wheel (Optional)

\section{A}

Evaluation

Questions

Questions

Computations

or Actual Value
Srinut /Redio (colitiol)

Functional Value 1

ECOLOGICAL INTEGRITY

\section{QUESTIONS TO ANSWER IN THE OFFICE:}

1. Percent of wetland having very poorly drained soils or Hydric A soils and/or open water.
2. Dominant land use zoning of wetland (see town zoning map). Use current land use if ditferent from what is zoned.

\section{QUESTIONS TO ANSWER IN THE FIELD:}

3. Water quality of the watercourse, pond, or lake associated with the welland.
4. Ratio of the number of occupied buildings within 500 feet of the wetland edge to the total area of the wetland (acres).

5. Percent of original welland filled.

6. Percent of wetland edge bordered by a butter of woodland or idle land at least 500 feet in width.

7. Level of human activity WITHIN WETLAND as evi. denced by litter, bike trails, roads, residences, etc.

\section{Suburtban Residentide}

\section{lacre: O buildings}

1.0

$\begin{array}{ll}\text { b. From } 10 \text { to } 50 \text { percent } & 0.5 \\ \text { c. More than } 50 \text { percent } & 0.1\end{array}$

$\begin{array}{ll}\text { a. More than } 80 \text { percent } & 1.0 \\ \text { b. From } 20 \text { to } 80 \text { percent } & 0.5 \\ \text { c. Less than } 20 \text { percent } & 0.1\end{array}$

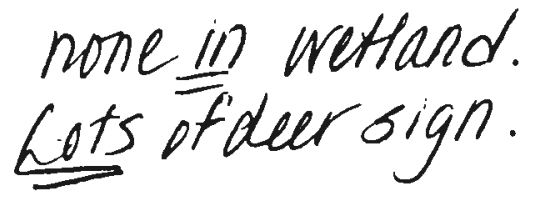

Cow level: Fow trails in 1.0 use and/or sparse litter

b. Moderate level: Some used trails, roads, eic.

c. High level: Many trails, roads, etc. within wetland 


\begin{tabular}{cccc}
\hline A & $B$ & $C$ & \\
Evaluation & Computations & Evaluation & Functional Valt \\
Questions & or Actual Value & Criteria & index (FVI) \\
\hline
\end{tabular}

QUESTIONS TO ANSWER IN THE FIELD (continued):

8. Level of human activity IN UPLAND within 500 feet of the wetland edge as evi denced by litter, bike trails, roads, residences, etc.

9. Percent of wetland plant community presently being attered by mowing, grazing, farming. or other activity. (Include areas now dominated by phragmites or purple bosestrife).

10. Percent of wetland actively being drained for agriculture or other purposes.

11. Number of public road andyor railroad crossings per 500 feet of wetland (measured along long axis of wetland).

12. Long-term stability. hiking trails for

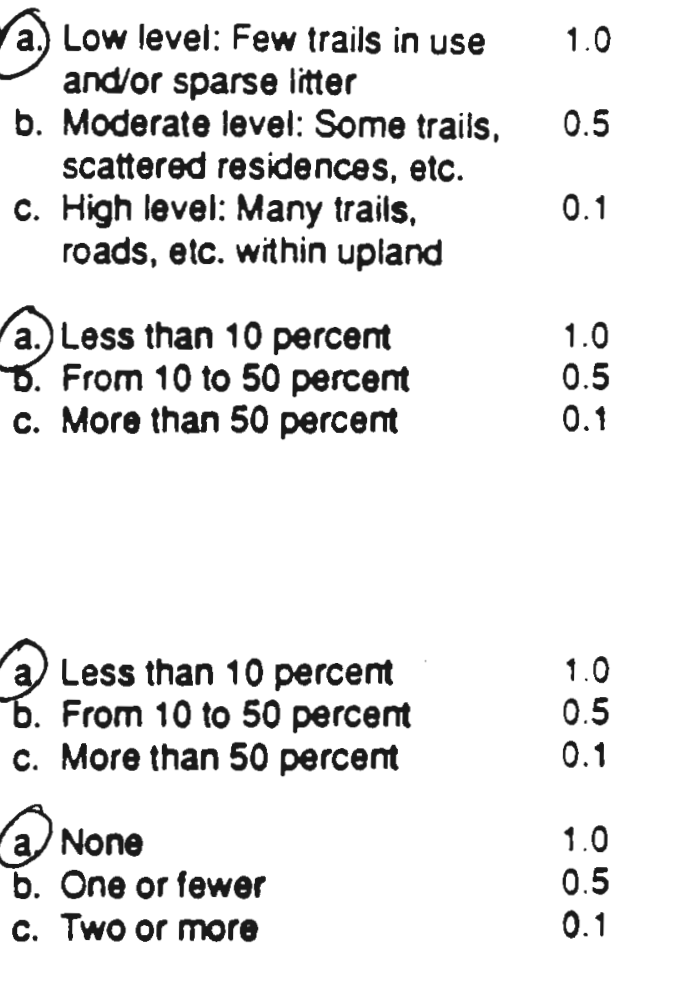

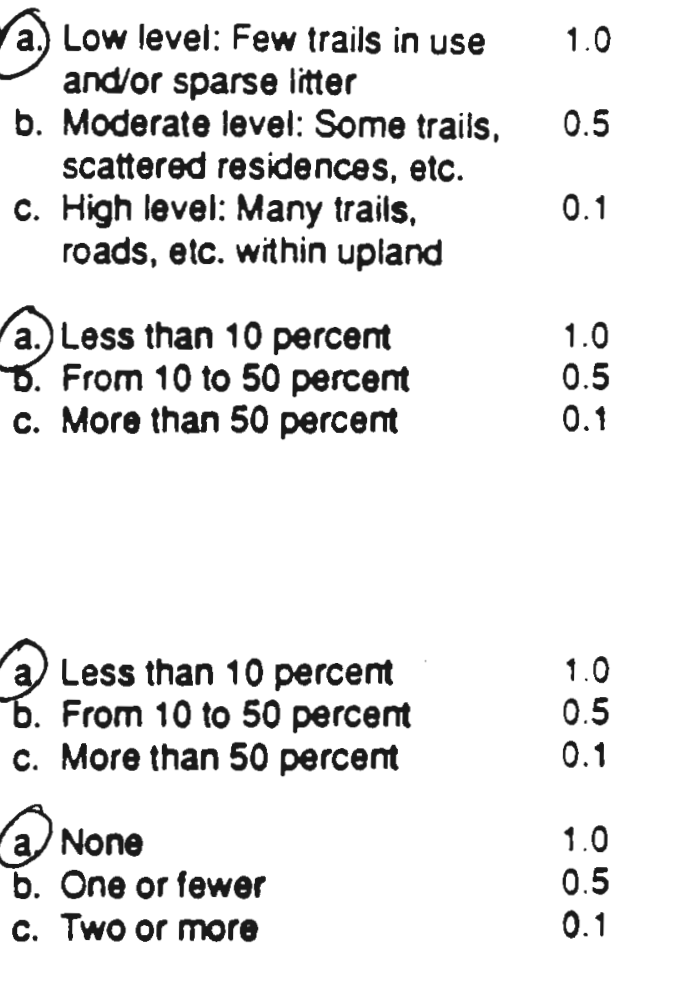

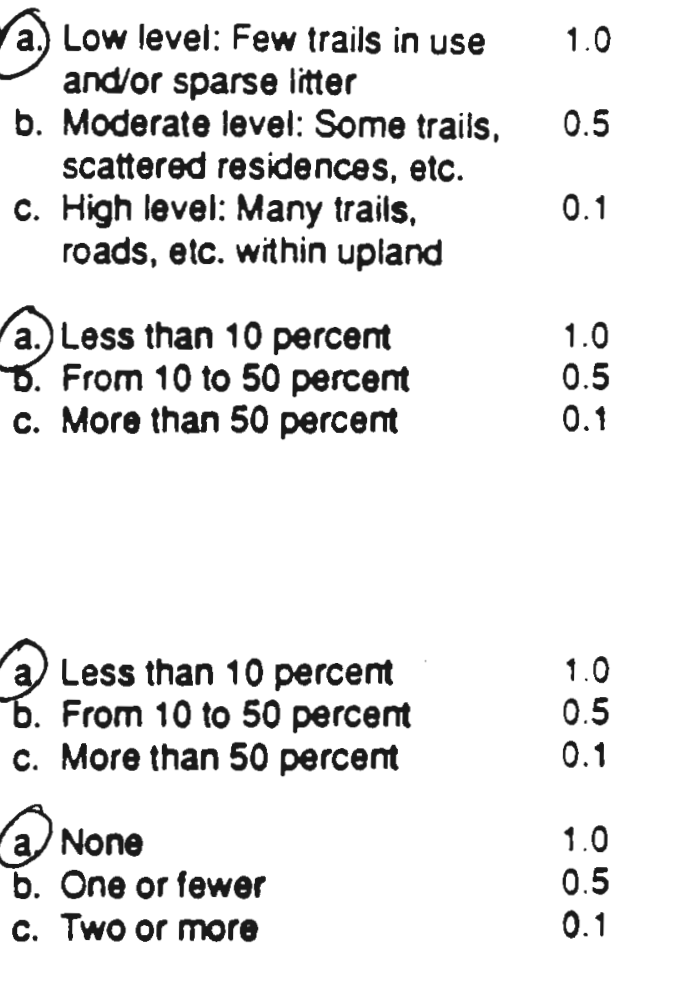

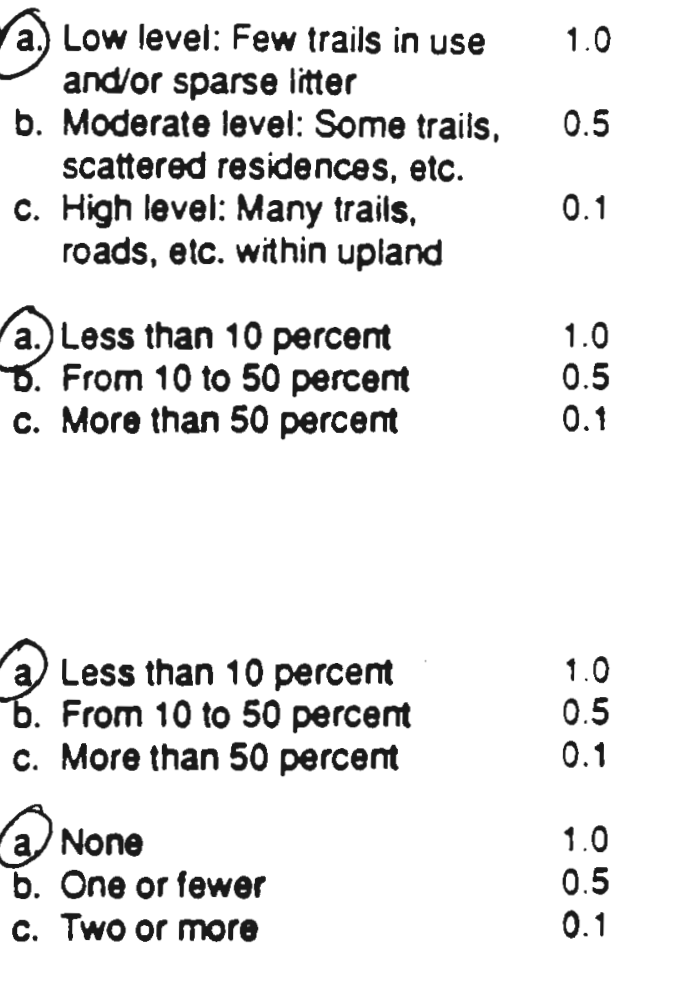

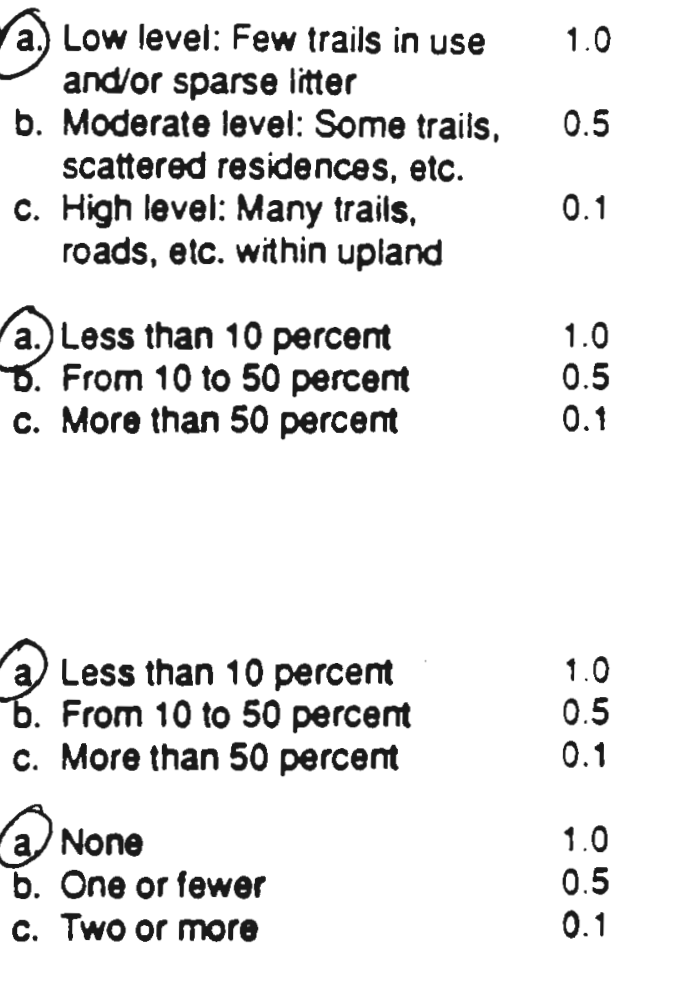

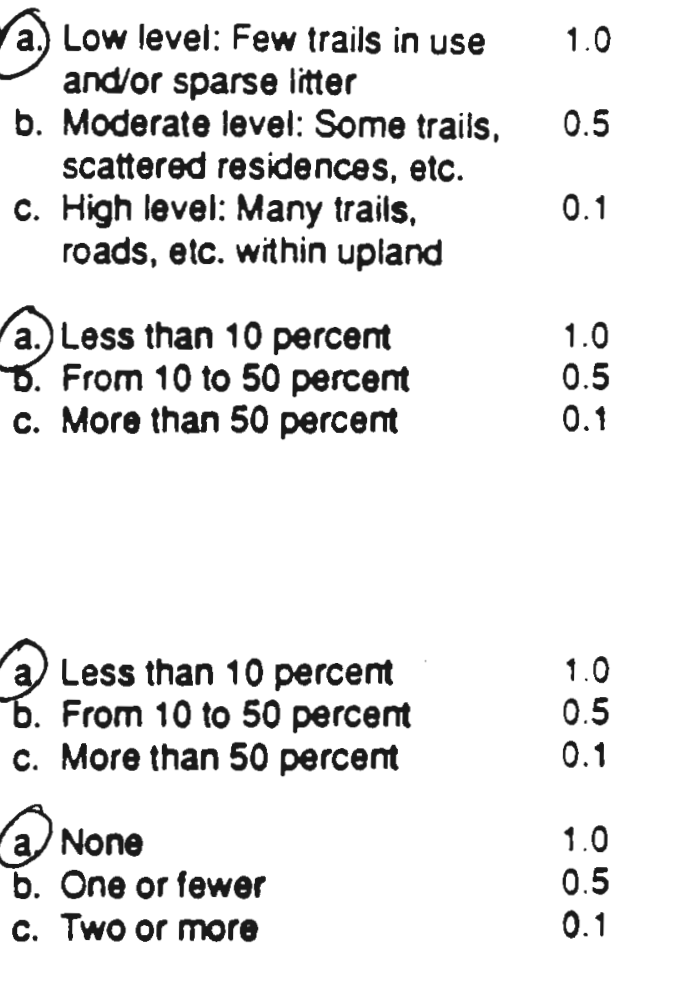

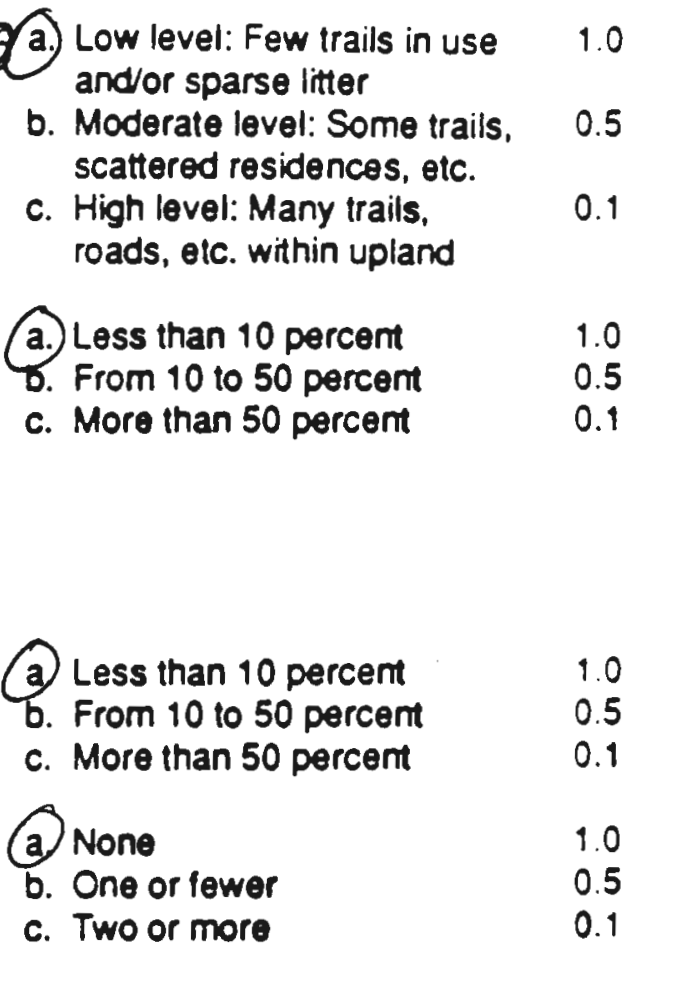

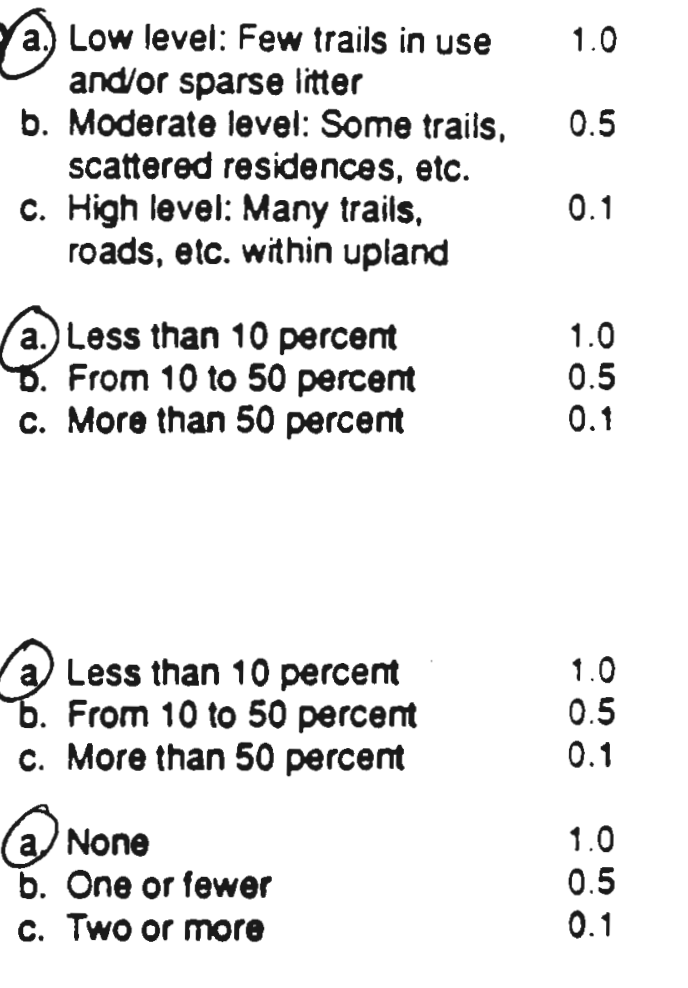

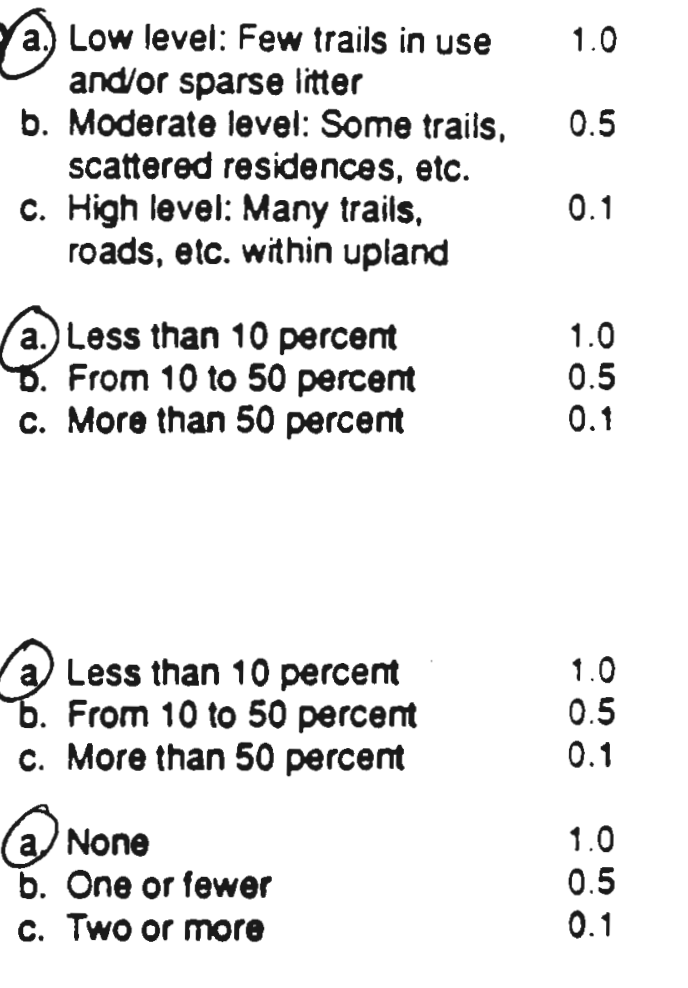

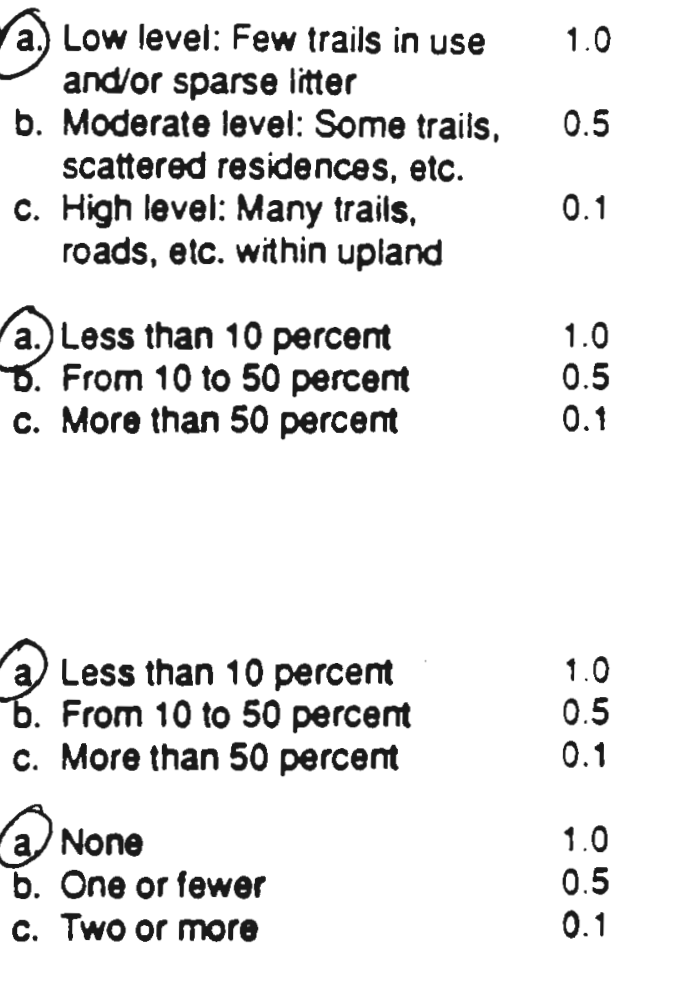

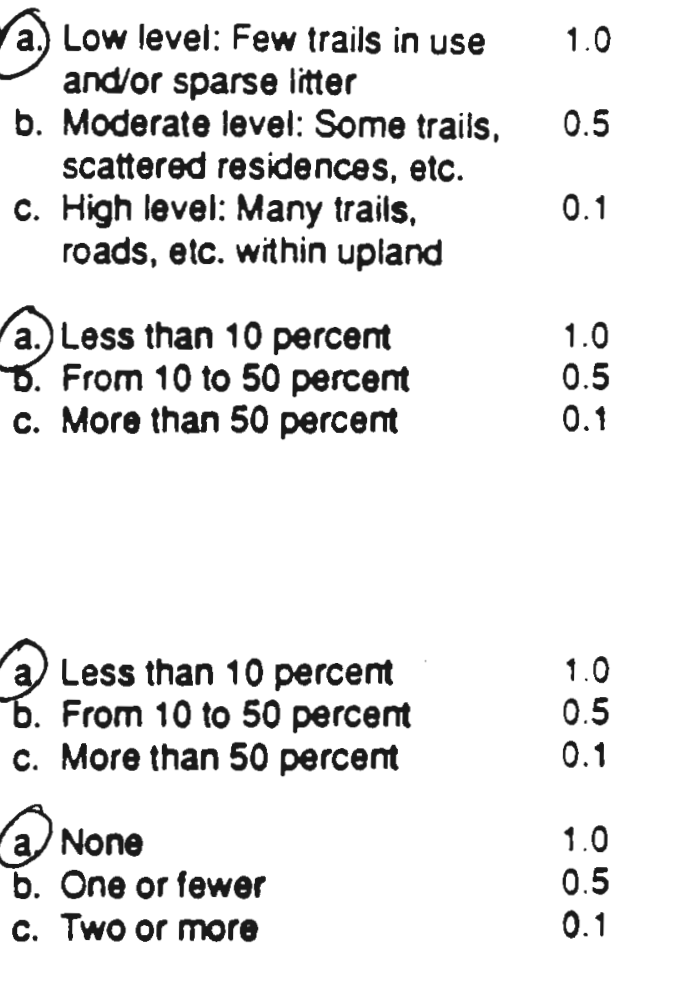

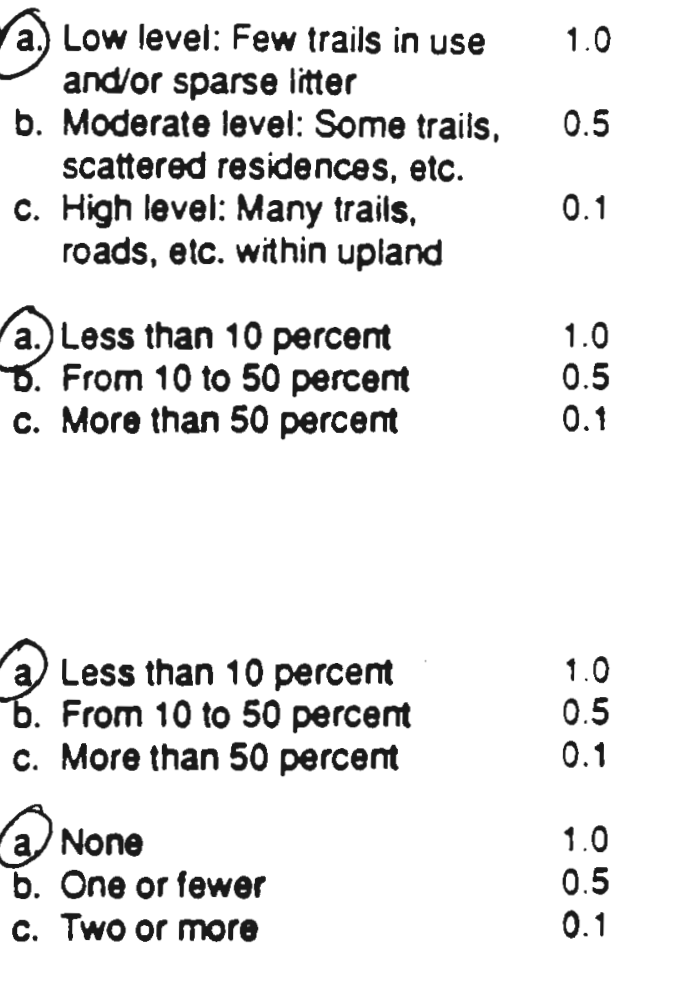

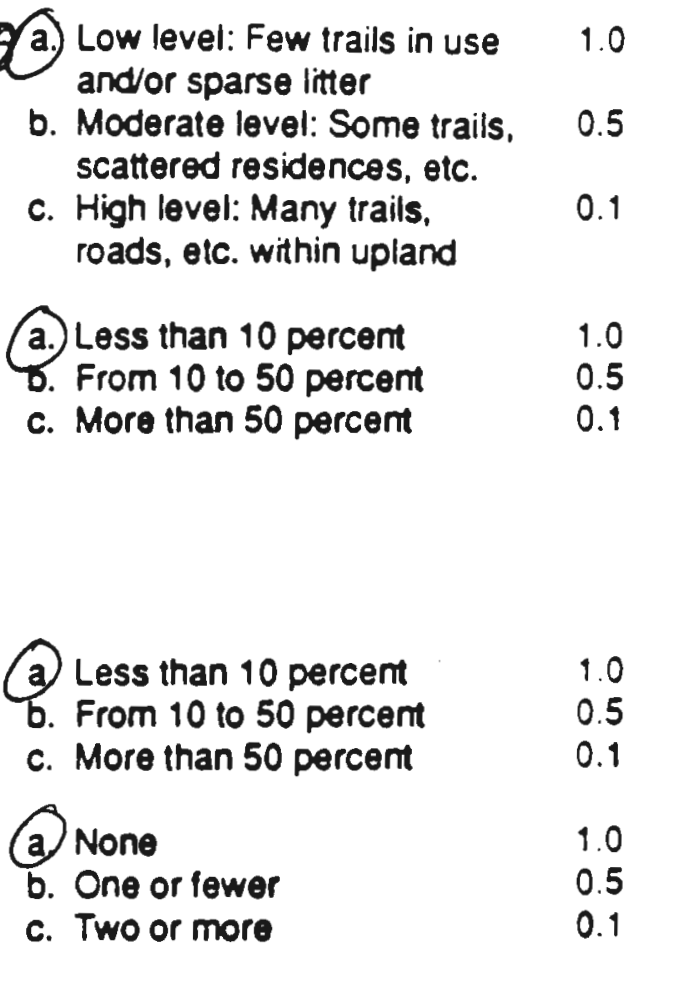

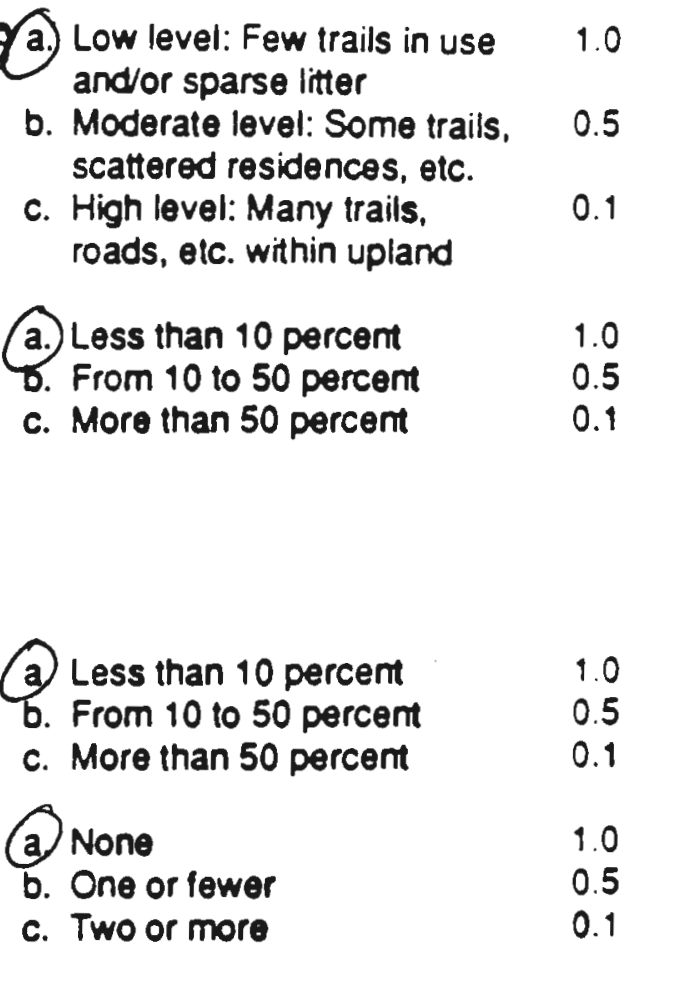

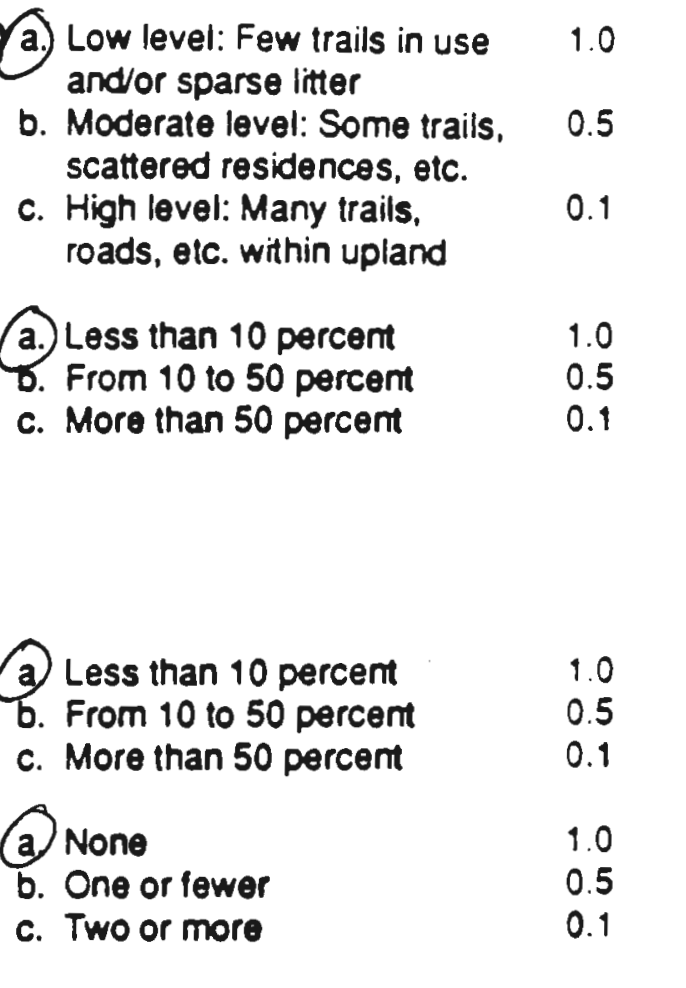

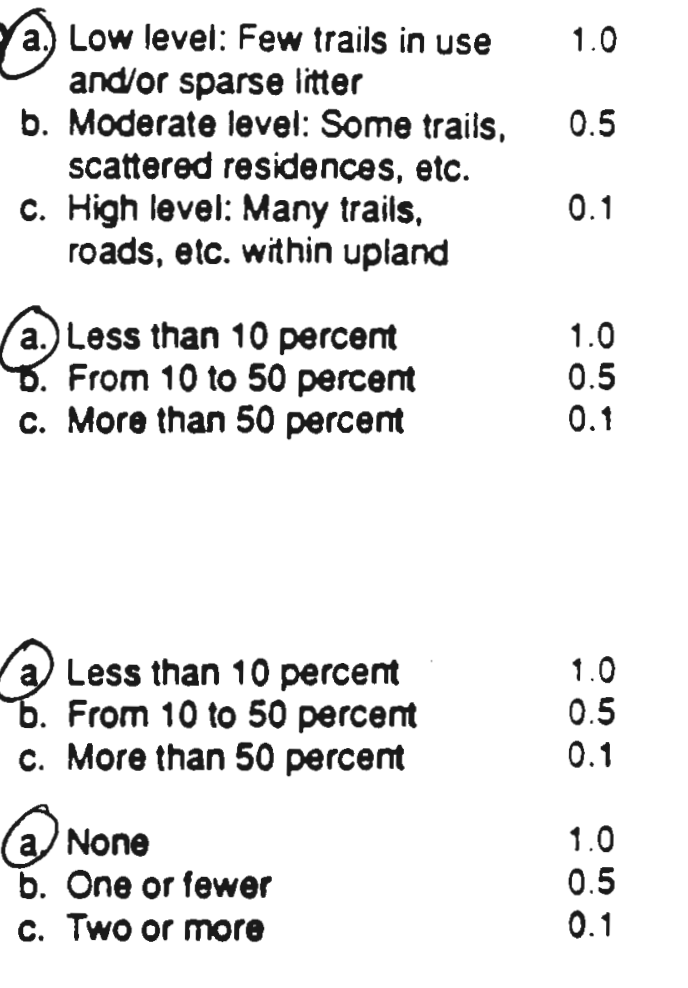

a. Wetland appears to be $\quad 1.0$ naturally occurring, not impounded by dam or dike

b. Welland appears to be somewhat dependent on artificial diking by dam, road, fill, elc.

AVERAGE FVI FOR FUNCTIONAL VALUE $1=$ Average of column D $=1958 \cdot 1 / .5 \div 12$

EVALUATION AREA FOR FUNCTIONAL VALUE 1 - Total area of welland = acres. 


\section{NEEDED FOR THIS EVALUATION:}

- USGS topographic map

- Land use map and/or recent aerial photographs

- Ruler or scale

- A method to calculate area (Dot grid, planimeter, etc.)

- N.H. Water Quality Report to Congress 305(b)
signat/Resce Coritil

Functional Value 2

WETLAND WILDLIFE HABITA
A

Evaluation Questions
Computations

or Actual Value
Evaluation
Criteria

Functional Valu

\section{QUESTIONS TO ANSWER IN THE OFFICE:}

1. Ecological integrity.

Average FVI from Functional Value 1

.958

2. Area of shallow permanent open water (less than 6 feet deep) including streams

in or adjacent to wetland.

a. More than 3 acres

b. From 0.5 to 3 acres

c. Less than 0.5 acre

1.0

0.5

0.1

\section{QUESTIONS TO ANSWER IN THE FIELD:}

3. Water quality of the watercourse,

FVI from Question V.1.3 lake, or pond associated with the wetland.
4. Wetland diversity.

a. Three or more wetland classes present

b. Two wetland classes present

c. One wetland class present

5. Dominamt wetland class.

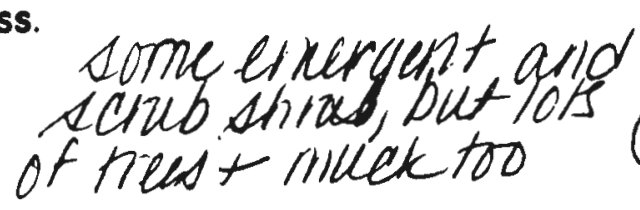

a. Emergent marsh andyor shallow open water

b. Forested and/or scrub-shrub wetland 0.5
c. Scrub-shrub saturated $(b 0 g)$ or wet meadow

6. Interspersion of vegetation

a. At least two wetland classes highly classes and/or open water. interspersed. Areas of each class scattered within wetland like a patchwork quilt

$$
\begin{aligned}
& \text { worle } \\
& \text { interisuersion }
\end{aligned}
$$




\begin{tabular}{cccc} 
A & 8 & $C$ & 0 \\
$\begin{array}{c}\text { Evaluation } \\
\text { Questions }\end{array}$ & $\begin{array}{c}\text { Computations } \\
\text { or Actual Value }\end{array}$ & $\begin{array}{c}\text { Evaluation } \\
\text { Criteria }\end{array}$ & $\begin{array}{c}\text { Functional Value } \\
\text { Index (FVI) }\end{array}$ \\
\hline
\end{tabular}

7. Welland juxtaposition.

8. Number of islands or inclusions of upland within wetland.

9. Wildlife access to other wetlands (overland). Travel lanes should be 50-100 feet wide. lots of hills/bumps

a. Two or more
b. One

c. None
1.0 wetlands within a 1 mile radius by perennial stream or lake

b. Wetland connected to other wetlands within a 1 to 3 mile radius by perennial stream or lake, OR other unconnected wetlands are present within a 1 mile radius

c. Wetland not hydrologically connected to other wetlands within 3 miles and no other unconnected wetlands within 1 mile

Free access along well vegetated stream comidor, woodland, or lakeshore

b. Accoss partially blocked by roads, urban areas, or other obstructions

c. Access blocked by roads, urban areas, or other obstructions

a. More than 40 percent bordered by upland wild"te c. Less than 10 percent active tamiand, or idle land) at least 500 feet in width.

\footnotetext{
AVERAGE FVI FOR FUNCTIONAL VALUE $2=$ Average of column $0 . .666 .(6.658 \div 10)$ EVALUATION AREA FOR FUNCTIONAL VALUE 2 = Total area of wetland acres.
} 


\section{SUMMARY SHEET FOR THE N.H. METHOD}

welland name or code Cheshire Wáste WVater Tunt. PIt. Total area or welland. 85 ackes county Neuitaven Town Cheshire, CT Date tugust 17, 1991 investigator(s) Stacittolcombe, David Hulseberg

\begin{tabular}{|c|c|c|c|}
\hline $\begin{array}{c}\text { A } \\
\text { Functlonal } \\
\text { Value }\end{array}$ & $\begin{array}{c}\text { B } \\
\text { FVI From } \\
\text { Data Sheots } \\
\end{array}$ & $\begin{array}{c}C \\
\text { Size of Evaluation } \\
\text { Area (Acres) }\end{array}$ & $\begin{array}{c}D \\
\text { Wetland Value Units } \\
B \times C\end{array}$ \\
\hline 1. Ecological Integrity & 629 & 85 & 535 \\
\hline 2. Wildlife Habitat & .553 & .85 & 470 \\
\hline $\begin{array}{l}\text { Finfish Habitat: } \\
\text { Part A - Rivers and Streams }\end{array}$ & & & 1.005 \\
\hline
\end{tabular}

4. Educational Potential

5. VisuaVAesthetic Ouality

6. Water Based Recreation

7. Flood Control Potential

8. Ground Water Use Potential

9. Sediment Trapping

10. Nutrient Attenuation

11. Shoreline Anchoring and

Dissipation of Erosive Forces

12. Urban Quality of Life

B: Wildife Habitat

C: Educational Opportunity

D: VisuaVAesthetic Quality

E: Water Based Recreation

13. Historical Site Potential

14. Noteworthiness 
NEEDED FOR THIS EVALUATION:

- Zoning máp

- SCS soils map

- N.H. Water Quality Report to Congress 305(b)

- USGS topographic map or recent aerial photograph

- A method to calculate area (Dot grid, planimeter, etc.)

- Ruler or scale

- Map wheel (Optional)

\section{A}

Evaluation

Questions
Cheshire waste vater Treatmigl

Functional Value 1

ECOLOGICAL INTEGRITY

UESTIONS TO ANSWER IN THE OFFICE:

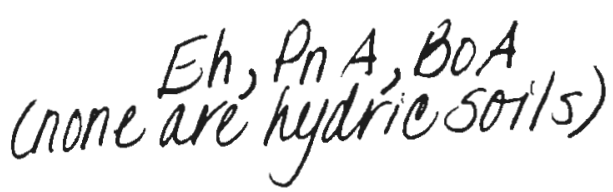

$R 40$

Computations or Actual Value
Evaluation

Criteria
Functional Vah Index (FVI)
1. Percent of wetland having very poorly drained soils or Hydric A soils and/or open water.
2. Dominant land use zoning of wetland (see town zoning map). Use curtent land use if different from what is zoned.

\section{QUESTIONS TO ANSWER IN THE FIELD:}

3. Water quality of the watercourse, pond, or lake associated with the wetland. a. More than 50 percent

b. From 25 to 50 percent

c. Less than 25 percent

1.0

0.5

0.1

a. Agriculture, forestry, or $\quad 1.0$ similar open space zoning

b. Rural residential

c. Commerciavindustrial, high density residential

a. High: Minimal pollution. 1.0 Actual water quality meets or exceeds Class $A$ or $B$ standards

b. Medium: Moderate pollution. Actual water quality is below Class $B$ standards

a. Less than 1 bldg: 10 acres $(<0.10)$

4. Ratio of the number of occupied buildings within 500 feet of the wetland edge to the lotal area of the wetland (acres).

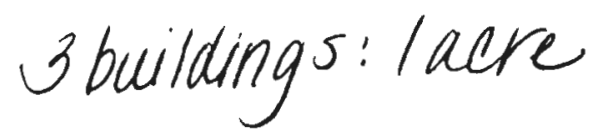

b. From 1 bldg: 10 acres 10 1 bldg: 2 acres $(0.10$. 0.50 )

c. More than 1 bldg: 2 acres $(>0.5)$

a. Less than 10 percent b. From 10 to 50 percent c. More than 50 percent

a. More than 80 percent b. From 20 to 80 percent c. Less than 20 percent 500 feet in width.

7. Level of human activity WITHIN WETLAND as evidenced by litter, bike irails. roads, residences, etc. a. Low level: Few trails in $\quad 1.0$ use and/or sparse litter

b. Moderate level: Some used trails, roads, etc.

c. High level: Many irails. roads, etc. within welland 


\begin{tabular}{cc}
$\begin{array}{c}\text { A } \\
\text { Evaluation } \\
\text { Questions }\end{array}$ & $\begin{array}{c}\text { B } \\
\text { Computations } \\
\text { or Actual Value }\end{array}$ \\
\hline ONS TO ANSWER IN THE FIELD (continued):
\end{tabular}

8. Level of human activity IN UPLAND within 500 feet of the welland edge as evi denced by litter, bike trails, roads, residences, etc.

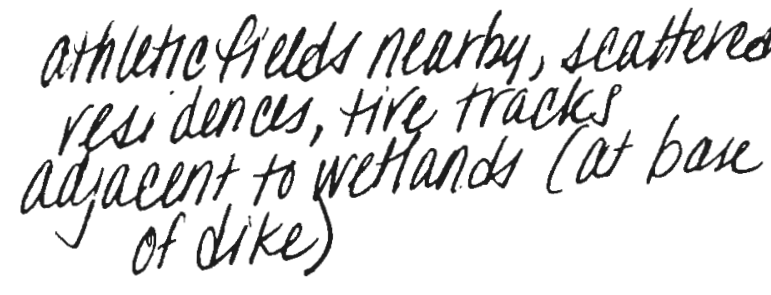

athleticfields nearby, scattered

a. Low level: Few trails in use

1.0 and/or sparse litter

Evaluation Criteria

b. Moderate level: Some trails, 0.5 scattered residences, etc.

c. High level: Many trails, roads, etc. within upland

a. Ress than 10 percent

1.0

some mowng adjacent to wetiand o at base of

b. From 10 to 50 percent

0.5

c. More than 50 percemt community presently being farming, or other activity. (Include areas now dominated dike by phragmites or purple bosestrite).

10. Percent of wetland actively being drained for agriculture

a. Less than 10 percent

r. From 10 to 50 percent or other purposes.

c. More than 50 percent

11. Number of public road and/or

(a.) None railroad crossings per 500 feet of wetland (measured along long axis of wetland).

b. One or fewer

c. Two or more

12. Long-term stability.

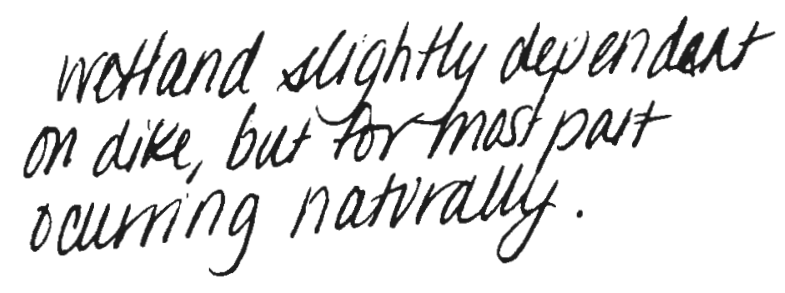

a. Wetland appears to be 75) naturally occurring, not 75. impounded by dam or dike

b. Wetland appears to be somewhat dependent on artificial diking by dam. road, fill, etc.

1.0
1.5
0.1
0.1

1.0
0.5
0.1


1.0
0.5
0.1
1.0
0.5
0.1
1.0
115

AVERAGE FVI FOR FUNCTIONAL VALUE $1=$ Average of column $0=.6+9 \cdot(7.55-17)$ EVALUATION AREA FOR FUNCTIONAL VALUE 1 = Total area of wetland acres. 


\section{NEEDED FOR THIS EVALUATION:}

- USGS topographic map

- Land use map and/or recent aerial photographs

- Ruler or scale

- A method to calculate area (Dot grid, planimeter, etc.)

- N.H. Water Quality Report 10 Congress 305(b)
Cheshire witp

Functional Value 2

WETLAND WILDLIFE HABITA,

\begin{tabular}{cccc}
\hline A & B & $C$ & 0 \\
Evaluation & Computations & Evalion & Functional Va:u \\
Questions & or Actual Value & Criteria & Index IFVIII \\
\hline
\end{tabular}

\section{QUESTIONS TO ANSWER IN THE OFFICE:}

1. Ecological integrity.

Average FVI from Functional Value 1.629

2. Area of shallow permanent open water lless than 6 feet deep) including streams

in or adjacent to wetland.
a. More than 3 acres
b. From 0.5 to 3 acres
C. Less than 0.5 acre

\section{QUESTIONS TO ANSWER IN THE FIELD:}

3. Water quality of the watercourse,

FVI from Question V.1.3

lake, or pond associated with the welland.

4. Wetland diversity.
a. Three or more wetland classes present
b. Two wetland classes present
c. One wetland class present

5. Dominam wetland class.

a. Emergent marsh and/or shallow open water

b. Forested and/or scrub-shrub wetland

0.5

c. Scrub-shnub saturated (bog) or wet meadow

6. Interspersion of vegetation classes and/or open water.

a. At least two wetland classes highly interspersed. Areas of each class scattered within wetland like a patchwork quilt

b. Moderate interspersion of wetland classes

c. Low degree of imterspersion. Each wetland class is more or less contiguous and separate from the other classes 


\begin{tabular}{cccc}
\hline A & Bvaluation & $C$ & C \\
Questions & $\begin{array}{c}\text { Computations } \\
\text { or Actual Value }\end{array}$ & $\begin{array}{c}\text { Evaluation } \\
\text { Critena }\end{array}$ & $\begin{array}{c}\text { Functional Value } \\
\text { Index (FVI) }\end{array}$ \\
\hline
\end{tabular}

7. Welland juxtaposition.

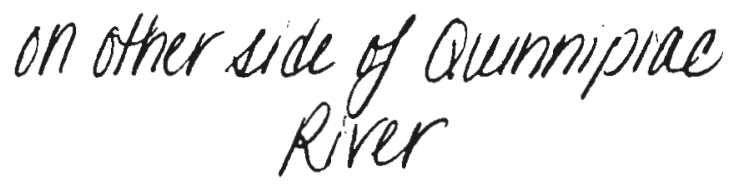

8. Number of islands or inclusions of upland within wetland.

9. Wildlife access to other wetlands (overtand). Travel lanes should be 50-100 feet wide.

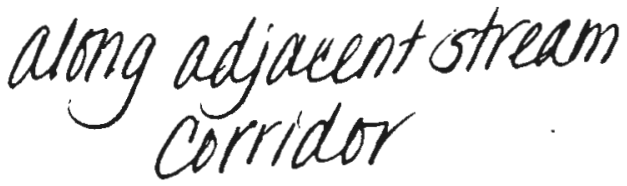

10. Percent of welland edge bordered by upland wildite habitat (brush, woodland, active farmland, or idle land) at least $\mathbf{5 0 0}$ feet in width. a. Welland connected to other 1.0 wetlands within a 1 mile radius by perennial stream or lake

b. Wetland connected to other wetlands within a 1 to 3 mile radius by perennial stream or lake, OR other unconnected wetlands are present within a 1 mile radius

c. Wetland not hydrologically connected to other wetlands within 3 miles and no other unconnected wetlands within 1 mile
a. Two or more
1.0
b. One
0.5
c. None
0.1

a. Free access abng well $\quad 1.0$ vegetated stream corridor, woodland, or lakeshore

b. Access partially blocked by roads, urban areas, or other obstructions

c. Access blocked by roads, urban areas, or other obstructions

a. More than 40 percent 1.0

b. From 10 to 40 percent

0.5

c. Less than 10 percent

AVERAGE FVI FOR FUNCTIONAL VALUE $2=$ Average of column $0=.55 \% \quad(5.529 \div 10)$ EVALUATION AREA FOR FUNCTIONAL VALUE 2 = Total area of welland = .85 acres. 


\section{SUMMARY SHEET FOR THE N.H. METHOD}

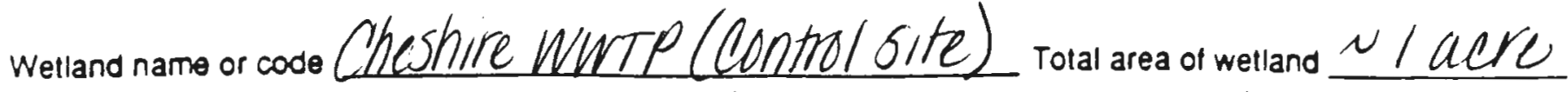
couny New taven rown Meriden, eT Das 9/20/91

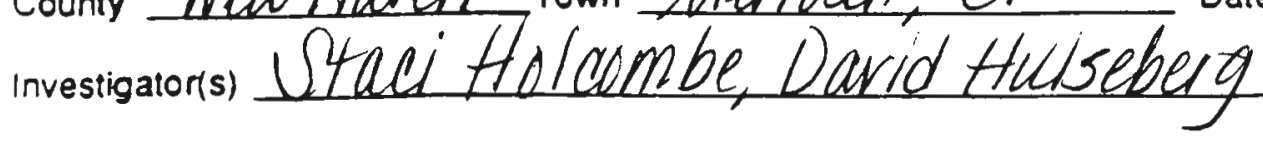

\begin{tabular}{|c|c|c|c|}
\hline $\begin{array}{c}\text { A } \\
\text { Functlonal } \\
\text { Value }\end{array}$ & $\begin{array}{c}\text { B } \\
\text { FVI From } \\
\text { Data Sheots }\end{array}$ & $\begin{array}{c}\text { C } \\
\text { Slze of Evaluation } \\
\text { Ares (Acres) }\end{array}$ & $\begin{array}{c}D \\
\text { Wetland Value Units } \\
B \times C\end{array}$ \\
\hline 1. Ecological Integrity & .675 & 1 & 2esters.625 \\
\hline 2. Wildlife Habitat & .468 & 1 & .400 \\
\hline $\begin{array}{l}\text { 3. Finfish Habitat: } \\
\text { Pant A - Rivers and Sireams }\end{array}$ & & & 1.143 \\
\hline
\end{tabular}

4. Educational Potential

5. VisuaVAesthetic Quality

6. Water Based Recreation

7. Flood Comrol Potential

8. Ground Water Use Potential

9. Sediment Trapping

10. Nutrient Attenuation

11. Shoreline Anchoring and

Dissipation of Erosive Forces

12. Urban Quality of Life
B: Wildifie Habitat
C: Educational Opportunity
D: VisuaVAesthetic Quality
E: Water Based Recreation

13. Historical Site Potential

14. Noteworthiness 
(ciuted off Resenorr Roded)

\section{NEEDED FOR THIS EVALUATION:}

- Zoning mẫ

- SCS soils map

- N.H. Water Quality Repon to Congress 305(b)

- USGS topographic map or recent aerial photograph

- A method to calculate area (Dot grid, planimeter, etc.)

- Ruler or scale

- Map wheel (Optional)

\section{A}

Evaluation

Questions

\section{Cheshire Control}

Functional Value 1 ECOLOGICAL INTEGRITY

\section{QUESTIONS TO ANSWER IN THE OFFICE:}

1. Percent of welland having very poorly drained soils or Hydric A soils and/or open water.

2. Dominant land use zoning of wetland (see town zoning map). Use current land use if different from what is zoned.

\section{QUESTIONS TO ANSWER IN THE FIELD:}

3. Water quality of the watercourse, pond, or lake associated with the wetland.

4. Ratio of the number of occupied buildings within 500 feet of the wetland edge to the total area of the wetland (acres).

5. Percent of original wetland filled.

6. Percent of wetland edge bordered by a butfer of woodland or idle land at least 500 reet in width.
B Computations or Actual Value
Evaluation

Criteria
Functional Vahu Index (FVI)
$R \cdot 80$

a. Agriculture, forestry, or similar open space zoning

b. Rural residential

c. CommerciaVindustrial, high density residential
1.0

0.5

0.1

b. From 25 to 50 percent

L. Less than 25 percent

a. $\mathrm{Hin}$

High: Minimal pollution. meets or exceeds Class $A$ or B standards

b. Medium: Moderate pollution. Actual water quality is below Class B stan. dards

a. Less than 1 bldg: 10 acres $(<0.10)$

$6: 10010$

b. From 1 bldg: 10 acres to 1 bldg: 2 acres 10.10 . 0.50)

c. More than 1 bldg: 2 acres ( $>0.5$ ) 


\begin{tabular}{cccc}
\hline A & $B$ & $C$ & $D$ \\
Evaluation & Computations & Evaluation & Functional Vaht \\
Questions & or Actual Value & Criteria & Index (FVI) \\
\hline
\end{tabular}

\section{QUESTIONS TO ANSWER IN THE FIELD (continued):}

8. Level of human activity IN UPLAND within 500 toet of the wetland edge as evi denced by litter, bike trails, roads, residences, etc.

9. Percent of wetland plant community presently being attered by mowing, grazing. farming, or other activity. (Include areas now dominated by phragmites or purple loosestrife).

10. Percent of wetland actively being drained for agriculture or other purposes.

11. Number of public road anc/or railroad crossings per 500 feet of wetland (measured along long axis of wetland).

12. Long-term stability.

beaver dam

\author{
3 houses wyin 500 feet $\begin{array}{ll}\text { a. Low level: Few trails in use } & 1.0 \\ \text { b. Moderate level: Some trails. } & 0.5 \\ \text { scattered residences, etc. } & \end{array}$ \\ c. High level: Many Irails, \\ roads, etc. within upland \\ a. Less than 10 percent $\quad 1.0$ \\ b. From 10 to 50 percent 0.5 \\ c. More than 50 percent 0.1
}

$\begin{array}{ll}\text { a. Less than } 10 \text { percent } & 1.0 \\ \text { b. From } 10 \text { to } 50 \text { percem } & 0.5 \\ \text { c. More than } 50 \text { percent } & 0.1\end{array}$

a. None 1.0

parking lot

b. One or fewer

0.5

0.1

a. Wetland appears to be naturally occurring, not impounded by dam or dike

0. Wetland appears to be somewhat dependent on artificial diking by dam, road, fill, etc.

AVERAGE FVI FOR FUNCTIONAL VALUE $1=$ Average of column D $=1675(8 \cdot 1-12)$

EVALUATION AREA FOR FUNCTIONAL VALUE 1 - Total area of welland acres. 
NEEDED FOR THIS EVALUATION:

- USGS topographic map

- Land use map and/or recent aerial photographs

- Ruler or scale

- A method to calculate area (Dol grid. planimeter, elc.)

- N.H. Water Quality Report 10 Congress 305(b)
Cheshire WWTH Conitie

\begin{tabular}{cccc}
\hline A & B & C & D \\
Evaluation & Computations & Evaluation & Functional Valu: \\
Questions & or Actual Value & Criteria & Index FVi! \\
\hline
\end{tabular}

\section{QUESTIONS TO ANSWER IN THE OFFICE:}

1. Ecological integrity.

2. Area of shallow permanent open water (less than 6 feet deep) including streams in or adjacent to wetland.
Average FVI from Functional Value 1

.675
a. More than 3 acres
b. From 0.5 to 3 acres
c. Less than 0.5 acre

3. Water quality of the watercourse, lake, or pond associated with the wetland.

4. Wetland diversity.
a. Three or more wetland classes present
b. Two wetland classes present
c. One wetland class present

5. Dominant wetland class.

a. Emergent marsh and/or shallow open water

b. Forested and/or scrub-shrub wetland

0.5

c. scrub-shrub saturated (bog) or 0.1 wet meadow

6. Interspersion of vegetation classes and/or open water.

a. At least two wetland classes highly interspersed. Areas of each class scattered within wetland like a patchwork quilt

b. Moderate interspersion of wetland classes

c. Low degree of interspersion. Each welland class is more or less contiguous and separate from the other classes 
WETLAND WILDLIFE HABITA (continued)

\begin{tabular}{|c|c|c|c|}
\hline $\begin{array}{c}\text { A } \\
\text { Evaluation } \\
\text { Questions }\end{array}$ & $\begin{array}{c}\text { B } \\
\text { Computations } \\
\text { or Actual Value }\end{array}$ & $\begin{array}{c}\text { C } \\
\text { Evaluation } \\
\text { Criteria }\end{array}$ & $\begin{array}{c}D \\
\text { Functional Value } \\
\text { Index (FVI) }\end{array}$ \\
\hline
\end{tabular}

7. Wetland juxtaposition.

a. Welland connected to other wetlands within a 1 mile radius by perennial stream or lake

b. Wetland connected to other wetlands within a 1 to 3 mile radius by perennial stream or lake, OR other unconnected wetlands are present within a 1 mile radius

c. Wetland not hydrologically connected to other wellands within 3 miles and no other unconnected wetlands within 1 mile

8. Number of islands or inclusions of upland within wetland.

9. Wildlife access to other wetlands (overland). Travel lanes should be 50-100 feet wide.

10. Percent of welland edge bordered by upland wildtite habitat (brush, woodland, active farmland, or idle land) at least $\mathbf{5 0 0}$ feet in wioth.
a. Two or more
1.0
b. One
c. None
0.5
0.1
a. Free access along well vegetated stream corridor, woodland, of lakeshore

b. Accoss partially blocked by roads, utban areas, or other obstructions

c. Accoss blocked by roads, urban areas, or other obstructions

AVERAGE FVI FOR FUNCTIONAL VALUE $2=$ Average of column D $=.468 \cdot(4.675 \div 10)$ EVALUATION AREA FOR FUNCTIONAL VALUE 2 = Total area of wetland = acres. 
wetland name or code Aiport 107010550 Nahere Park toral area of wetland 3.8 a eres

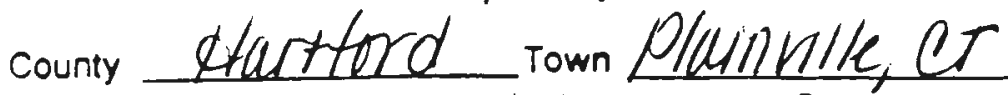
investganors Staci Holcombe, Darid thuseberg

\section{A}

Functlonal

Value

1. Ecological Integrity

2. Wildlife Habitat

3. Finfish Habitat:

Part A - Rivers and Streams

Part $B$ - Ponds and Lakes
B

FVI From

Data Sheots

.563

.806
Size of Evaluation Area (Acres)

3.8

3.8
Date Alyust 17,1991

4. Educational Potential

5. VisuaVAesthetic Quality

6. Water Based Recreation

7. Flood Control Polential

8. Ground Water Use Potential

9. Sediment Trapping

10. Nutrient Attenuation

11. Shoreline Anchoring and

Dissipation ol Erosive Forces

12. Urban Quality of Life

B: Wildlife Habitat

C: Educational Opportunity

D: VisuaVAesthetic Quality

E: Water Based Recreation

13. Historical Site Potential

14. Noteworthiness 
- SCS soils map

- N.H. Water Quality Report to Congress 305(b)

- USGS topographic map or recent aerial pholograph

- A method to calculate area (Dot grid, planimeter, etc.)

- Ruler or scale

- Map wheel (Optional)

$\begin{array}{cc}\text { A } & \text { B } \\ \text { Evaluation } & \text { Computations } \\ \text { Questions } & \text { or Actual Value }\end{array}$

Evaluation

Functional Valu

Criteria

index FVII

\section{QUESTIONS TO ANSWER IN THE OFFICE:}

1. Percent of wetland having very poorty drained soils or Hydric A soils and/or open water.

2. Dominamt land use zoning of wetland (see town zoning map). Use current land use if different from what is zoned.

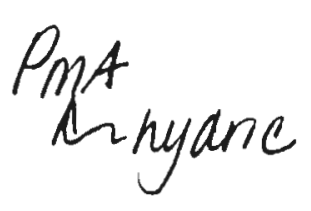

a. More than 50 percent

T. From 25 to 50 percent

c. Less than 25 percent

Resmeted Iridustrial similar open space

\section{QUESTIONS TO ANSWER IN THE FIELD:}

a. Agriculture, forestry, or 1.0 zoning

b. Rural residential

c. CommerciaVindustrial, high density residential

3. Water quality of the watercourse, pond, or lake associated with the wetland. wasteranctiot?

a. High: Minimal pollution. 1.0
Actual water quality meets or exceeds Class A or B standards

b. Medium: Moderate pollu. tion. Actual water quality is below Class B standards

4. Ratio of the number of occupied buildings within 500 feet of the welland edge to the total area of the wetland (acres).

5. Percent of original wetland filled.
N 14 buildings: 3.800 


$\begin{array}{cc}\begin{array}{c}\text { A } \\ \text { Evaluation } \\ \text { Questions }\end{array} & \begin{array}{c}\text { B } \\ \text { Computations } \\ \text { or Actual Value }\end{array} \\ \text { ONS TO ANSWER IN THE FIELD (continued): }\end{array}$

8. Level of human activity iN UPLAND within 500 teet of the wetland edge as evi denced by litter, bike trails, roads, residences, etc.
9. Percent of wetland plamt community presently being altered by mowing, grazing, farming, or other activity. (Include areas now dominated by phragmites or purple bosestrite).

10. Percent of wetland actively being drained for agriculture or other purposes.

11. Number of public road andyor railroad crossings per 500 feet of wetland (measured along long axis of welland).

ho roads /RR's that arz puralle and adjacent- a. Low level: Few trails in use $\quad 1.0$ and/or sparse litter

b. Moderate level: Some trails, $\quad 0.5$ scattered residences, etc.

c. High level: Many trails, roads, etc. within upland

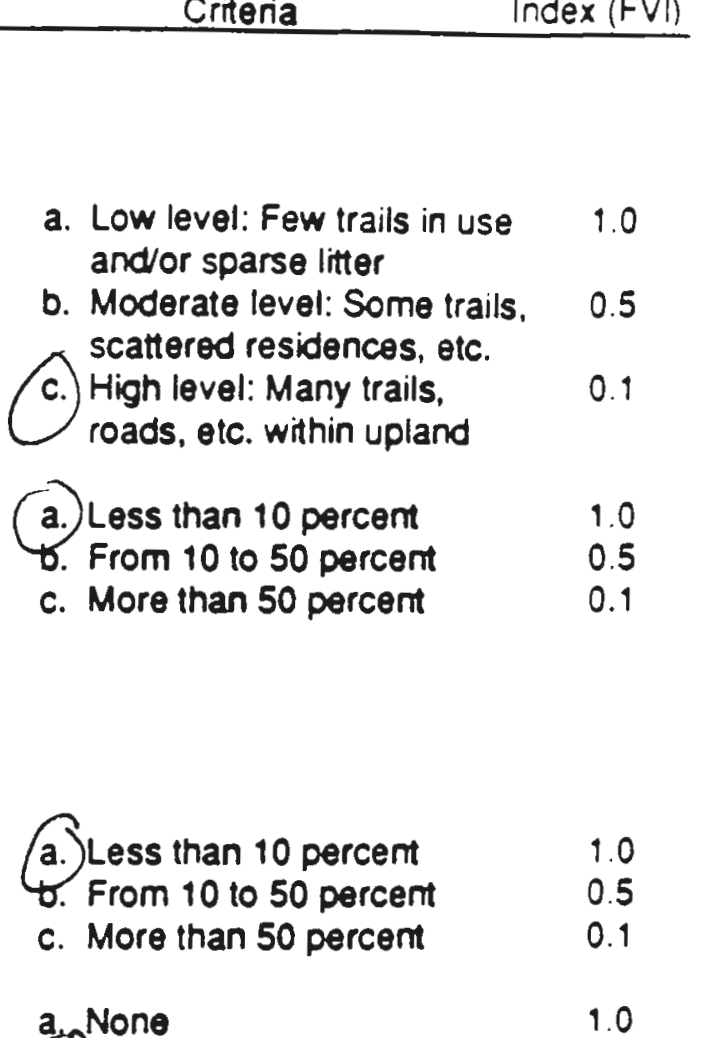
a. Less than 10 percent
t. From 10 to 50 percent
1.0
c. More than 50 percent
0.5
0.1

a. None

b. One or fewer

c. Two or more

0.5

0.1

b. Wetland appears o be dike somewhat dependent on artiticial diking by dam. road, fill, etc.

AVERAGE FVI FOR FUNCTIONAL VALUE $1=$ Average of column $0=.563(6.75 \div 12)$ EVALUATION AREA FOR FUNCTIONAL VALUE $1=$ Total area of welland $=3.8$ acres. 


\section{NEEDED FOR THIS EVALUATION:}

- USGS topographic map

- Land use map and/or recent aerial photographs

- Ruler or scale

- A method to calculate area (Dot grid, planimeter, etc.)

- N.H. Water Quality Report to Congress 305(b)
Ribersom Anpint

Functional Value 2

WETLAND WILOLIFE HABITA

\begin{tabular}{|c|c|c|c|}
\hline $\begin{array}{l}\text { A } \\
\text { Evaluation } \\
\text { Questions }\end{array}$ & $\begin{array}{c}\text { B } \\
\text { Computations } \\
\text { or Actual Value }\end{array}$ & $\begin{array}{c}\text { C } \\
\text { Evaluation } \\
\text { Criteria }\end{array}$ & $\begin{array}{c}\text { D } \\
\text { Functiona! Valu } \\
\text { Index (FVI) }\end{array}$ \\
\hline
\end{tabular}

\section{QUESTIONS TO ANSWER IN THE OFFICE:}

1. Ecological integrity.

2. Area of shallow permanent open water (less than 6 feet deep) including streams in or adjacent to wetland.
Average FVI from Functional Value 1

363
1.0
0.5
0.1

a. More than 3 acres

b. From 0.5 to 3 acres

c. Less than 0.5 acre

\section{QUESTIONS TO ANSWER IN THE FIELD:}

3. Water quality of the watercourse, lake, or pond associated with the wetland.

FVI from Question V.1.3

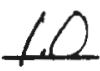

4. Wetland diversity.

a. Three or more wetland classes present

b. Two wetland classes present

0.5

c. One wetland class present

5. Dominamt wetland class.

a.)

Emergem marsh and/or shallow open water

b. Forested and/or scrub-shrub wetland

0.5

c. Scrub-shnub saturated (bog) or wet meadow

6. Interspersion of vegetation classes and/or open water.

a.

At least two wetland classes highly interspersed. Areas of each class scattered within wetland like a patchwork quill

b. Moderate interspersion of wetland classes

c. Low degree of interspersion. Each wetland class is more or less contiguous and separate from the other classes 


\begin{tabular}{cccc} 
A & B & $C$ & \\
$\begin{array}{c}\text { Evaluation } \\
\text { Questions }\end{array}$ & $\begin{array}{c}\text { Computations } \\
\text { or Actual Value }\end{array}$ & $\begin{array}{c}\text { Evaluation } \\
\text { Criteria }\end{array}$ & $\begin{array}{c}\text { Functional Value } \\
\text { Index (FVI) }\end{array}$ \\
\hline
\end{tabular}

\section{Wetland juxtaposition.}

8. Number of islands or inclusions of upland within wetland.

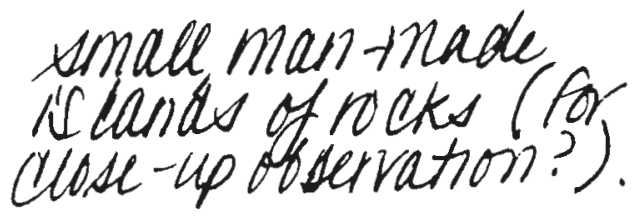

9. Wildife access to other wetlands (overland). Travel lanes should be 50-100 feet wide.

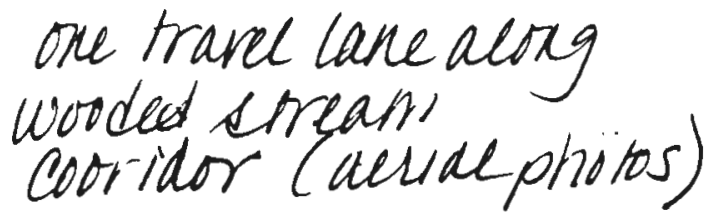

a.) Wetland connected to other
wetlands within a 1 mile radius
by perennial stream or lake

b. Welland connected to other wellands within a 1 to 3 mile radius by perennial stream or lake, OR other unconnected wetlands are present within a 1 mile radius

c. Wetland not hydrologically connected to other wetlands within 3 miles and no other unconnected wetlands within 1 mile
1.0

0.5

0.1

a. Free access along well $\quad 1.0$ vegetated stream comidor, woodland, or lakeshore

b. Access partially blocked by 0.5 roads, urban areas, or other obstructions

c. Access blocked by roads, urban areas, or other obstructions
10. Percent of welland edge bordered by upland wild"ute habitat (brush, woodland, active farmland, or idle land) at least 500 feet in width.

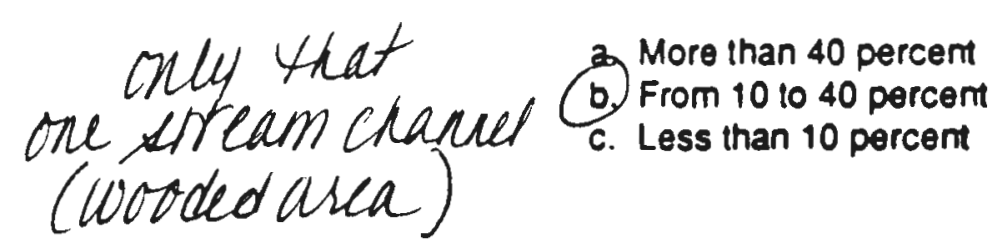

1.0

0.5

0.1

AVERAGE FVI FOR FUNCTIONAL VALUE $2=$ AVerage of column D $=.806 \cdot(8.063: 10)$ EVALUATION AREA FOR FUNCTIONAL VALUE 2 = Total area of wetland = acres. 


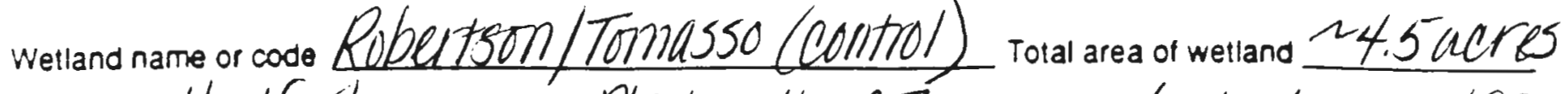

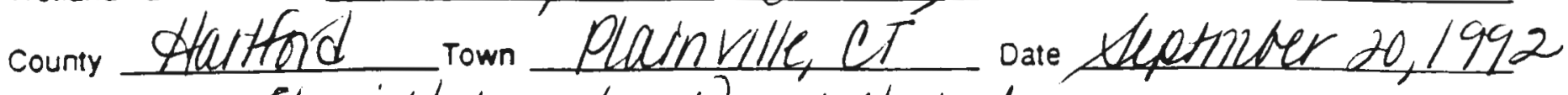

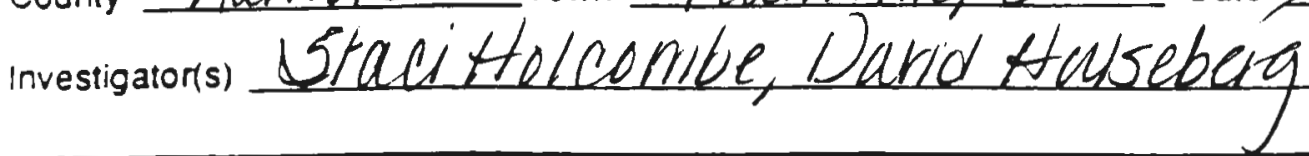

A

Functlonal

Value

1. Ecological Integrity

2. Wildlife Habitat

3. Finfish Habitat:

Part A - Rivers and Streams

Part $B$ - Ponds and Lakes

\section{Size of Evaluation} Area (Acres)

FVI From

Data Shoots

.779

.763
4.5

4.5
Wetland Value Units $B \times C$

4. Educational Potential

5. VisuaVAesthetic Quality

\section{Water Based Recreation}

\section{Flood Control Potential}

8. Ground Water Use Potential

\section{Sediment Trapping}

10. Nutrient Altenuation

11. Shoreline Anchoring and Dissipation of Erosive Forces

12. Urian Quality of Life
8: Wildlife Habitat
C: Educational Opponunity
D: VisuaVAesthetic Quality
E: Water Based Recreation

13. Historical Site Potential

14. Noteworthiness 
(AH Farmily IOO Re $)$
NEEDED FOR THIS EVALUATION:

Ribertanilierianes Conts

- Zoning mấ

ECOLOGICAL INTEGRITY

- SCS soils map

- N.H. Water Quality Repon to Congress 305(b)

- USGS topographic map or recent aerial photograph

- A method to calculate area (Dot grid, planimeter, etc.)

- Ruler or scale

- Map wheel (Optional)

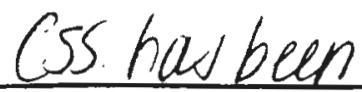

A

Evaluation

Questions
Computations

or Actual Value
C

Evaluation

Criteria
Functional Vah. Index (FVI)

\section{QUESTIOHSS TO ANSWER IN THE OFFICE:}

1. Percent of wetland having very poorly drained soils or Hydric A soils and/or open water.

2. Dominant land use zoning of wetland (see town zoning map). Use current land use if differem Trom what is zoned.

\section{QUESTIONS TO ANSWER IN THE FIELD:}

3. Water quality of the watercourse, pond, or lake associated with the wetland.

4. Ratio of the number of occupied buildings within 500 teet of the wetland edge to the total area of the wetland (acres).

5. Percent of original wetland filled.

6. Percent of welland edge bordered by a buffer of woodland or idle land at least 500 teet in width.

7. Level of human activity WITHIN WETLAND as evidenced by litter, bike trails, roads, residences, etc.
a. More than 50 percent
1.0
b. From 25 to 50 percent
0.5
c. Less than 25 percent
0.1

'b zoneed thicdpluin, 1/3 ared industrial (restrieted). Howerer

a. Agriculture, forestry, or $\quad 1.0$ presentluns use id iural residential similar open space zoning

b. Aural residential $\quad 0.5$

c. CommerciaVindustrial, $\quad 0.1$ high density residential

\section{unnamed tributary of the Pequabueck River.}

thomes: 4.5 acses
a. Aligh: Minimal pollution. Actual water quality meets or exceeds Class A or $\mathbf{B}$ standards
b. Medium: Moderate pollu- tion. Actual water quality is below Class B stan- dards
a. Less than 1 bldg: 10 acres $(<0.10)$
b. From 1 bldg: 10 acres to 1 blog: 2 acres (0.10. $0.50)$
c. More than 1 bidg: 2 acres (>0.5)

t. From 10 to 50 percent

c. More than 50 percent

0.5

0.1

$\begin{array}{ll}\text { 2. More than } 80 \text { percent } & 1.0 \\ \text { b. From } 20 \text { to } 80 \text { percent } & 0.5 \\ \text { c. Less than } 20 \text { percent } & 0.1\end{array}$

a. Low level: Few trails in $\quad 1.0$ use and/or sparse litter

b. Moderate level: Some used trails, roads, etc.

c. High level: Many trails, roads, etc. within wetland 


\begin{tabular}{cccc}
\hline A & $B$ & $C$ & 0 \\
Evaluation & Computations & Evaluation & Functional Val \\
Questions & or Actual Value & Criteria & Index (FVI) \\
\hline
\end{tabular}

QUESTIONS TO ANSWER IN THE FIELD (continued):

8. Level of human activity iN UPLAND within 500 teet of the wetland edge as ovi denced by litter, bike trails, roads, residences, etc.

9. Percent of wetland plant community presently being altered by mowing, grazing, farming, or other activity. (Include areas now dominated by phragmites or purple bosestrife).

10. Percent of wetland actively being drained for agriculture or other purposes.

11. Number of public road and/or railroad crossings per 500 feet of wetland (measured along long axis of wetland).

12. Long-term stability.

\section{few resideness}

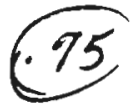

a. Low level: Few trails in use 1.0

$\rightarrow$ and/or sparse litter

b. Moderate level: Some trails, $\quad 0.5$ scattered residences, etc.

c. High level: Many trails, roads, etc. within upland

a. Less than 10 percent

b. From 10 to 50 percent

c. More than 50 percent a. Less than 10 percent

b. From 10 to 50 percent

c. More than 50 percemt

a. None

b. One or lewer

c. Two or more
1.0

0.5

0.1

1.0

0.5

0.1

a. Wetland appears to be naturally occurring, not impounded by dam or dike

b. Wetland appears to be somewhat dependent on antificial diking by dam, road, fill, etc.

AVERAGE FVI FOR FUNCTIONAL VALUE $1=$ Average of column D $=1,179(9.35 \div 12)$
EVALUATION AREA FOR FUNCTIONAL VALUE $1=$ Tolal area of wetland $=\frac{4.5}{4}$ acres. 
NEEDED FOR THIS EVALUATION:

- USGS topographic map

- Land use map and/or recent aerial pholographs

- Ruler or scale

- A method to calculate area (Dot grid, planimeter, etc.)

- N.H. Water Quality Report to Congress 305(b)

\begin{tabular}{cccc}
\hline A & $\mathbf{B}$ & $C$ & D \\
Evaluation & Computations & Evaluation & Functional Valu \\
Questions & or Actual Value & Criteria & Index (FVIi \\
\hline
\end{tabular}

\section{QUESTIONS TO ANSWER IN THE OFFICE:}

1. Ecological integrity.

2. Area of shallow permanent open water (less than 6 leet deep) including streams

in or adjacent to welland.
Average FVI from Functional Value 1

\section{QUESTIONS TO ANSWER IN THE FIELD:}

3. Water quality of the watercourse,

FVI from Question V.1.3 lake, or pond associated with the welland.

4. Wetland diversity.

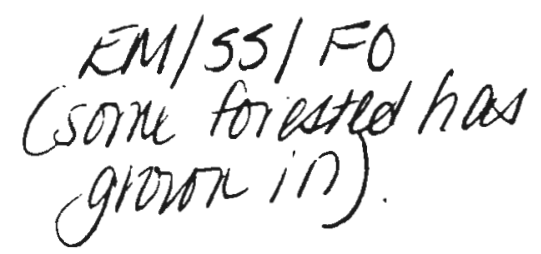

15

a. Three or more wetland classes

1.0

$\rightarrow$ presem

b. Two wetland classes present

0.5

c. One wetland class present

0.1

5. Dominant wetland class.

6. Interspersion of vegetation classes and/or open water. a. Emergent marsh and/or shallow $\quad 1.0$ open water

b. Forested and/or scrub-shnub wetland 0.5

c. Scrub-shrub saturated (bog) or wet meadow

a. Al least two welland classes highly interspersed. Areas of each class scattered within wetland like a patchwork quit

b. Moderate interspersion of wetland classes

c. Low degree of interspersion. Each wetland class is more or less contiguous and separate from the other classes 
WETLAND WILDLIFE HABITA (continued)

\begin{tabular}{cccc}
\hline A & B & $C$ & Cotion \\
Evaluation & $\begin{array}{c}\text { Computations } \\
\text { or Actual Value }\end{array}$ & $\begin{array}{c}\text { Evaluation } \\
\text { Criteria }\end{array}$ & $\begin{array}{c}\text { Functional Value } \\
\text { Index (FVI) }\end{array}$ \\
\hline
\end{tabular}

7. Wetland juxtaposition.

8. Number of islands or inclusions of upland within welland.

9. Wildlife access to other wetlands (overland). Travel lanes should be 50-100 feet wide.

10. Percent of wetland edge bordered by upland wild"le habitat (brush, woodland, active farmland, or idle land) at least 500 feet in width.

\section{a.}

Wetland connected to other wetlands within a 1 mile radius by perennial stream or lake

b. Wetland connected to other wetlands within a 1103 mile radius by perennial stream or lake, OA other unconnected wetlands are present within a 1 mile radius

c. Wetland not hydrologically connected to other wetlands within 3 miles and no other unconnected wellands within 1 mile

a. Two or more $\quad 1.0$

b. One

0.5

c. None

0.1

a. Free access abong well $\quad 1.0$ vegetated stream corridor. woodland, or lakeshore

b. Access partially blocked by roads, uban areas, or other obstructions

c. Access blocked by roads, urtan areas, or other obstruc. tions

AVERAGE FVI FOR FUNCTIONAL VALUE $2=$ Average of column D $=1763 .(7.629 \div 10)$
EVALUATION AREA FOR FUNCTIONAL VALUE $2=$ Total area of wetland $=$\begin{tabular}{l}
4.5 \\
\hline
\end{tabular} 


\section{SUMMARY SHEET FOR THE N.H. METHOD}

Wetland name or code CT. D.T.T - Reute 7 Total area of wetland G.lacres

county Fairtield Town Nonwalk, CT Date August 13,1991

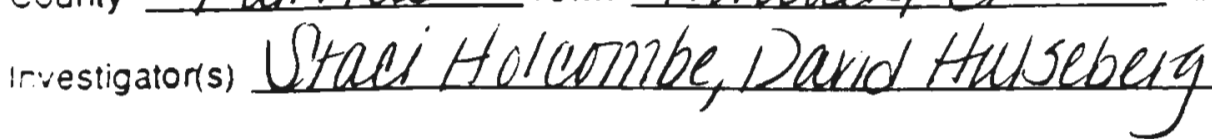

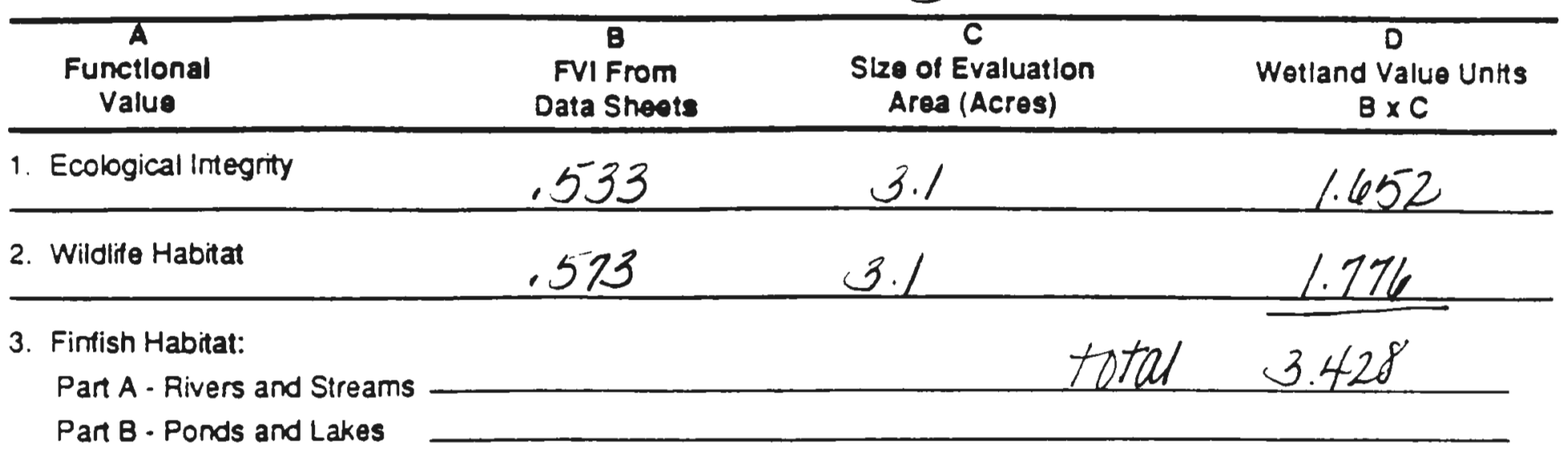

4. Educational Potential

5. VisuaVAesthetic Quality

6. Water Based Recreation

7. Flood Control Potential

8. Ground Water Use Potential

\section{Sediment Trapping}

10. Nutrient Attenuation

11. Shoreline Anchoring and

Dissipation of Erosive Forces

12. Uroan Quality of Life

B: Wildlife Habitat

C: Educational Opportunity

D: VisuaVAesthetic Quality

E: Water Based Recreation

13. Historical Site Potential

14. Noteworthiness 
- Zoning máp

- SCS soils map

- N.H. Water Quality Report to Congress 305(b)

- USGS topographic map or recent aerial photograph

- A method to calculate area (Dot grid, planimeter, etc.)

- Ruler or scale

- Map wheel (Optional)

\section{A}

Evaluation

Questions
Computations

or Actual Value

\section{QUESTIONS TO ANSWER IN THE OFFICE:}

1. Percent of wetland having very poorly drained soils or Hydric A soils and/or open water.

2. Dominant land use zoning of wetland (see town zoning map). Use currem land use if ditferent from what is zoned.

$$
\text { CrC, CAB, Rn, HpC }
$$

RHO a. More than 50 percent 1.0

b. From 25 to 50 percent 0.5

c. Less than 25 percent 0.1
Functional Vah Index (FVI)

a. Agriculture, forestry, or 1.0 similar open space zoning

b) Rural residential $\quad 0.5$

c. Commercialindustrial, $\quad 0.1$

\section{QUESTIONS TO ANSWER IN THE FIELD:} high density residential 3. Water quality of the water-
course, pond, or lake associated with the wetland. soure-intermitten unnaned toteam a. High: Minimal pollution. 1.0 Actual water quality meets or exceeds Class A or $B$ standards

b. Medium: Moderate pollution. Actual water quality is below Class B standards

a. Less than 1 bldg:

10 acres $(<0.10)$
b. From 1 bldg: 10 acres 10
1 bldg: 2 acres $(0.10$. 1 bldg: 2 acres $(0.10$. 0.50)

c. More than 1 bldg: 2 acres (>0.5)

a. Less than 10 percent b. From 10 to 50 percent c. More than 50 percent

6. Percent of wetland edge bordered by a butfer of woodland or idle land at least 500 teet in width.

7. Level of human activity WITHIN WETLAND as evidenced by litter, bike trails, roads, residences, etc.

$$
4.18 \text { ac filled }
$$

very lithe beewese $W+5$ is argued by hiyl ioek clift $E$ acentible rowidife a. More than 80 percent

b. From 20 to 80 percent

c. Less than 20 percent

a. Low level: Few trails in 1.0 use and/or sparse litter

b. Moderate level: Some used trails, roads, etc.

c. High level: Many trails, roads, etc. within wetland 


$\begin{array}{cc}\begin{array}{c}\text { A } \\ \text { Evaluation } \\ \text { Questions }\end{array} & \begin{array}{c}8 \\ \text { Computations } \\ \text { or Actual Value }\end{array} \\ \text { ONS TO ANSWER IN THE FIELD (continued): }\end{array}$

8. Level of human activity IN UPLAND within 500 feet of

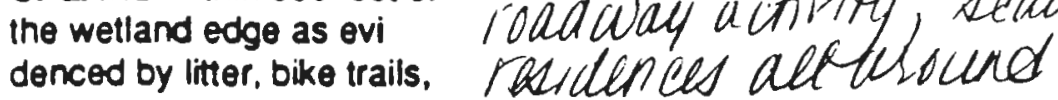
roads, residences, etc.

9. Percent of wetland plant community presently being attered by mowing, grazing. constiuction at preserit ther roadway actinty; stiutted resdences allelound farming, or other activity. (Include areas now dominated by phragmites or purple bosestrife).

10. Percent of wetland actively being drained for agriculture or other purposes.

none detected

11. Number of public road andror railroad crossings per 500 feet of wetland (measured along long axis of wetland).

$$
\text { CTRE } 1
$$

a. Low level: Few trails in use

1.0 and/or sparse litter

b. Moderate level: Some trails, $\quad 0.5$ scattered residences, elc.

c. High level: Many trails, roads, etc. within upland

a. Less than 10 percent

b. From 10 to 50 percem

c. More than 50 percent
Functional $V a$ ! Index (FVI)

\section{QUESTIONS TO ANSWER IN THE FIELD (continued):}

12. Long-term stability.

a. Less than 10 percent $\quad 1.0$

b. From 10 to 50 percent 0.5

c. More than 50 percent 0.1

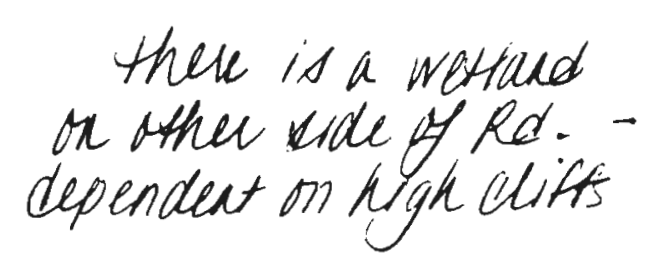
2. None
b. One or fewer
1.0
c. Two or more
0.5
0.1

a. Wetland appears to be naturally occurring, not impounded by dam or dike

b. Wetland appears to be somewhat dependent on antificial diking by dam. road, fill, etc.

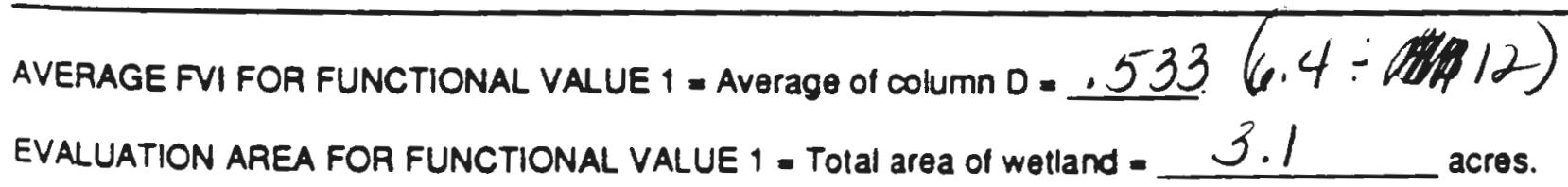
acres. 


\section{NEEDED FOR THIS EVALUATION:}

- USGS topographic map

- Land use map and/or recem aerial photographs

- Ruler or scale

- A method to calculate area (Dot grid, planimeter, etc.)

- N.H. Water Quality Repon to Congress 305(b)

\begin{tabular}{cccc}
\hline$A$ & $B$ & $C$ & $D$ \\
Evaluation & Computations & Evaluation & Functional Va \\
Questions & or Actual Value & Criteria & Index (FVi \\
\hline
\end{tabular}

\section{QUESTIONS TO ANSWER IN THE OFFICE:}

1. Ecological integrity.

2. Area of shallow permanent open water (less than 6 feet deep) including streams

in or adjacent to wetland.
Average FVI from Functional Value 1

533

1.0

0.5

0.1

\section{QUESTIONS TO ANSWER IN THE FIELD:}

3. Water quality of the watercourse,

FVI from Question V.1.3 lake, or pond associated with the wetland.

4. Wetland diversity.

$$
E M / S S
$$
a. Three or more wetland classes present
b. Two wetland classes present
0.5
c. One wetland class present

5. Dominant wetland class.
a. Emergent marsh andjor shallow $\quad 1.0$ open water

b. Forested andror scrub-shrub wetland 0.5
c. Scrub-shrub saturated (bog) or wet meadow

6. Interspersion of vegetation

a. At least two wetland classes highly classes andror open water. interspersed. Areas of each class scaltered within welland like a

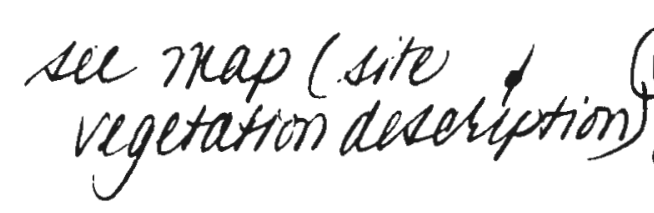
patchwork quilt

b. Moderate interspersion of welland classes

c. Low degree of interspersion. Each wetland class is more or less con. tiguous and separate from the other classes 
WETLAND WILDLIFE HABITA (cominued)

\begin{tabular}{cccc}
\hline A & $B$ & $C$ & $D$ \\
Evaluation & Computations & Evaluation & Functional Value \\
Questions & or Actual Value & Criteria & Index (FVI) \\
\hline
\end{tabular}

7. Wetland juxtaposition.

a. Wetland connected to other wetlands within a 1 mile radius

by perennial stream or lake

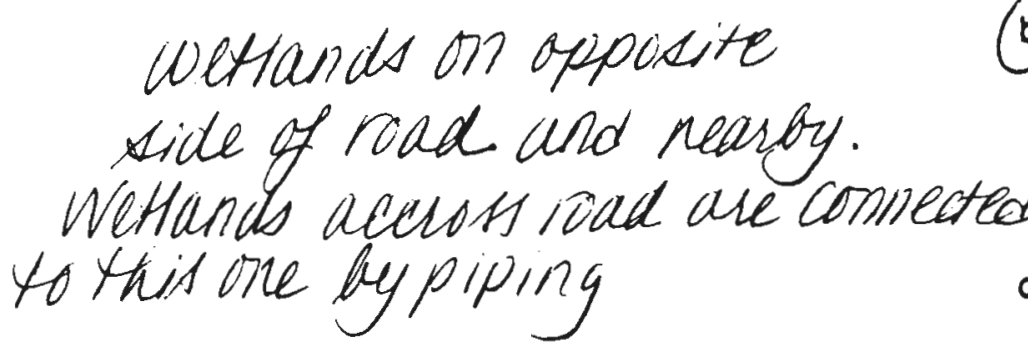

b. Wetland connected 10 other wellands within a 1 to 3 mile radius by perennial stream or lake, OR other unconnected wellands are present within a 1 mile radius

c. Wetland not hydrologically connected to other wetlands within 3 miles and no other unconnected wetlands within 1 mile

8. Number of islands or inclusions of upland within

sle map

a. Two or more
b. One
c. None welland.

9. Wildlife access to other wellands (overland). Travel lanes should be 50-100 feet wide.

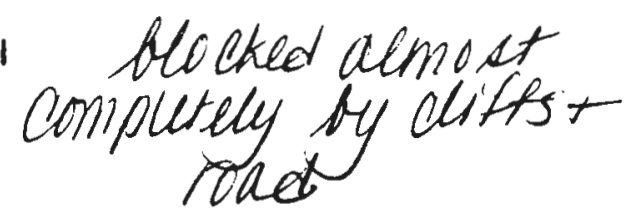
a. Free access along well vegetaled stream comidor. woodland, or lakeshore
b. Access partially blocked by roads, utban areas, or other obstructions
c. Access blocked by roads. urban areas, or other obstruc- tions

10. Percent of wetland edge bordered by upland wild"te habitat (brush, woodland, active farmland, or idle land)

a. More than 40 percent

AVERAGE FVI FOR FUNCTIONAL VALUE $2=$ AVerage of column D $=.573(5.733 \div 10)$

EVALUATION AREA FOR FUNCTIONAL VALUE 2 - Tolal area of wetland $=31$ acres. 


\section{SUMMARY SHEET FOR THE N.H. METHOD}

Welland name or code QT DCT, Nte 7 (cotitrolsite) Total area of wetland 3 aces county Fuirfield Town Wilton Ci

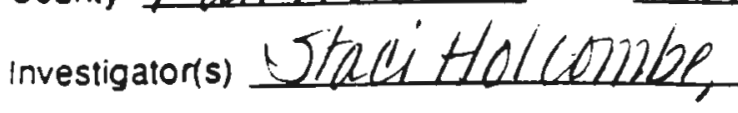

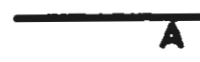

Functional

Value

1. Ecological Integrity

2. Wildlife Habitat

3. Fintish Habitat:

Pan $A$ - Rivers and Streams

Part $B$ - Ponds and Lakes
Dare Lepterafer 30,199,

4. Educational Potential

5. VisuaVAesthetic Quality

6. Water Based Recreation

7. Flood Control Polential

8. Ground Water Use Potential

9. Sediment Trapping

10. Nutrient Attenuation

11. Shoreline Anchoring and

Dissipation of Erosive Forces

12. Urian Quality of Life

8: Wildlife Habitat

C: Educational Opportunity

$D$ : VisuaVAesthetic Quality

$E$ : Water Based Recreation

13. Historical Site Potential

14. Noteworthiness

FVI From
Data Sheot

.683

.498

3

3
D

Slze of Evaluation

Area (Acres)

2.049
Wetland Value Units

$\mathrm{B} \times \mathrm{C}$

1.494 total 3.543 
NEEDED FOR THIS EVALUATION:

- Zoning mã

- SCS soils map

- N.H. Water Quality Report to Congress 305(b)

- USGS topographic map or recent aerial photograph

- A method to calculate area (Dot grid, planimeter, etc.)

- Ruler or scale

- Map wheel (Optional)

A

Evaluation

Questions
Functional Value 1

ECOLOGICAL INTEGRITY

\section{QUESTIONS TO ANSWER IN THE OFFICE:}

1. Percent of wetland having very poorly drained soils or Hydric A soils and/or open water.

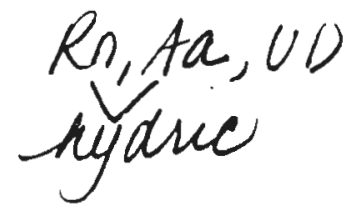

2. Dominant land use zoning of wetland (see town zoning map). Use current land use if<smiles>[Mg][Ca]</smiles>

\section{QUESTIONS TO ANSWER IN THE FIELD:}

3. Water quality of the watercourse, pond, or lake associated with the wetland.
4. Ratio of the number of occupied buildings within 500 teet of the wetland edge to the total area of the welland (acres).

5. Percent of original wetland filled.

none evident a. More than 50 percent
b. From 25 to 50 percent
c. Less than 25 percent
$\begin{aligned} & 0.5 \\ & \text { a. Agriculture, forestry, or } \\ & \text { similar open space }\end{aligned}$
$\begin{aligned} & \text { 2oning } \\ & \text { b. Rural residential } \\ & \text { CommerciaVindustrial, } \\ & \text { high density residential }\end{aligned}$

a. More than 50 percent
b. From 25 to 50 percent
c. Less than 25 percent

$\begin{aligned} & \text { a. Agriculture, forestry, or } \\ & \text { similar open space }\end{aligned}$
$\begin{aligned} & \text { zoning } \\ & \text { b. Rural residential } \\ & \text { CommerciaVindustrial, } \\ & \text { high density residential }\end{aligned}$

a. More than 50 percent
b. From 25 to 50 percent
c. Less than 25 percent

$\begin{aligned} & \text { a. Agriculture, forestry, or } \\ & \text { similar open space }\end{aligned}$
$\begin{aligned} & \text { zoning } \\ & \text { b. Rural residential } \\ & \text { CommerciaVindustrial, } \\ & \text { high density residential }\end{aligned}$

a. More than 50 percent
b. From 25 to 50 percent
c. Less than 25 percent

$\begin{aligned} & \text { a. Agriculture, forestry, or } \\ & \text { similar open space }\end{aligned}$
$\begin{aligned} & \text { zoning } \\ & \text { b. Rural residential } \\ & \text { CommerciaVindustrial, } \\ & \text { high density residential }\end{aligned}$

a. More than 50 percent
b. From 25 to 50 percent
c. Less than 25 percent

$\begin{aligned} & \text { a. Agriculture, forestry, or } \\ & \text { similar open space }\end{aligned}$
$\begin{aligned} & \text { zoning } \\ & \text { b. Rural residential } \\ & \text { CommerciaVindustrial, } \\ & \text { high density residential }\end{aligned}$

a. More than 50 percent
b. From 25 to 50 percent
c. Less than 25 percent

$\begin{aligned} & \text { a. Agriculture, forestry, or } \\ & \text { similar open space }\end{aligned}$
$\begin{aligned} & \text { zoning } \\ & \text { b. Rural residential } \\ & \text { CommerciaVindustrial, } \\ & \text { high density residential }\end{aligned}$

a. More than 50 percent
b. From 25 to 50 percent
c. Less than 25 percent

$\begin{aligned} & \text { a. Agriculture, forestry, or } \\ & \text { similar open space }\end{aligned}$
$\begin{aligned} & \text { zoning } \\ & \text { b. Rural residential } \\ & \text { CommerciaVindustrial, } \\ & \text { high density residential }\end{aligned}$
5 houses: $3 a c$

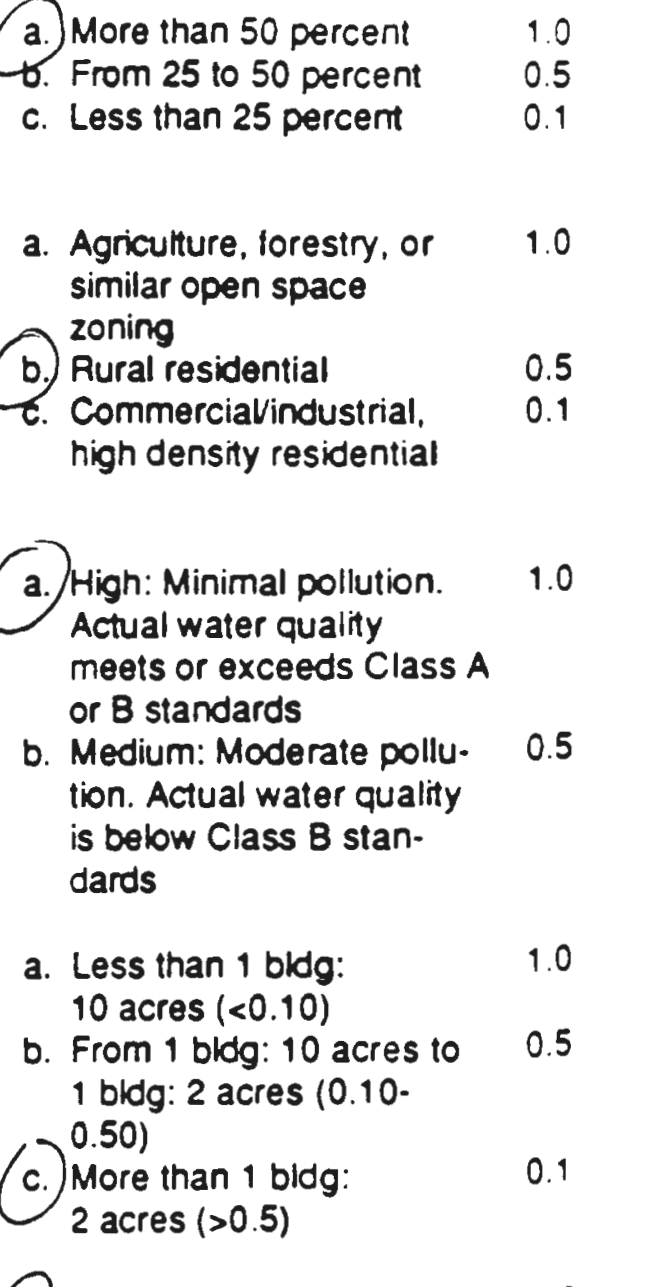
a. Less than 1 bldg: 10 acres $(<0.10)$
b. From 1 blog: 10 acres to 1 bldg: 2 acres $(0.10$.
(c.50)
(c.) More than 1 bidg:
2 acres (>0.5)

Less than 10 percent

6. Percent of wetland edge bordered by a buffer of woodland or idle land at least

2. More than 80 percent

b. From 20 to 80 percent

C. Less than 20 percent

500 leet in width.

7. Level of human activity WITHIN WETLAND as OVidenced by litter, bike trails, roads, residences, etc. 


\begin{tabular}{cccc}
\hline A & Bvaluation & $C$ & 0 \\
Questions & Computations & Evaluation & Functional Valt \\
or Actual Value & Criteria & Index (FVI) \\
\hline
\end{tabular}

QUESTIONS TO ANSWER IN THE FIELD (continued):

8. Level of human activity IN UPLAND within 500 feet of the wetland edge as evi denced by litter, bike trails. roads, residences, etc.

9. Percemt of wetland plant community presently being attered by mowing, grazing. farming, or other activity. (Include areas now dominated by phragmites or purple bosestrife).

10. Percent of wetland actively being drained for agriculture or other purposes.

11. Number of public road and/or railroad crossings per 500 leet of wetland (measured along long axis of wetland).

12. Long-term stability.

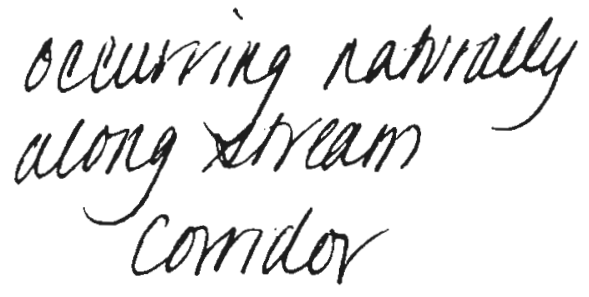

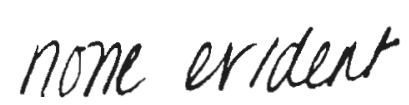

1 crosses wettand
1 Loal Costes sarbouding a. Low level: Few irails in use 1.0 rural redidential meighorizod

and/or sparse litter

b. Moderate level: Some trails, 0.5 scattered residences, etc.

c. High level: Many trails, roads, etc. within upland

a. Less than 10 percent b. From 10 to 50 percent c. More than 50 percent a. Less than 10 percent

6. From 10 to 50 percent

c. More than 50 percent

2. None

b. One or tewer

c. Two or more

a. Wetland appears to be naturally occurring, not impounded by dam or dike

b. Wetland appears to be somewhat dependent on antificial diking by dam, road, lill, etc.
1.0

0.5

0.1

1.0

0.5

0.1

AVERAGE FVI FOR FUNCTIONAL VALUE $1=$ Average of column D $=\operatorname{lele83}(8.2 ; 12)$ EVALUATION AREA FOR FUNCTIONAL VALUE 1 - Total area of welland = acres. 
NEEDED FOR THIS EVALUATION:

- USGS topographic map

- Land use map and/or recemt aerial photographs

- Ruler or scale

- A method to calculate area (Dot grid, planimeter, etc.)

- N.H. Water Quality Report to Congress 305(b)

\begin{tabular}{cccc}
\hline$A$ & 8 & $C$ & $D$ \\
$\begin{array}{c}\text { Evaluation } \\
\text { Questions }\end{array}$ & Computations & Evaluation & Functional Va \\
or Actual Value & Criteria & Index iFV: \\
\hline
\end{tabular}

\section{QUESTIONS TO ANSWER IN THE OFFICE:}

1. Ecological integrity.

2. Area of shallow permanem open water (less than 6 feet deep) including streams in or adjacent to wetland.
Average FVI from Functional Value

.683
a. More than 3 acres
b. From 0.5 to 3 acres
c. Less than 0.5 acre

\section{QUESTIONS TO ANSWER IN THE FIELD:}

3. Water quality of the watercourse, lake, or pond associated with the

FVI from Question V.1.3 wetland.

4. Wetland diversity.

a. Three or more wetland classes present

b. Two wetland classes present

c. One wetland class presem

5. Dominant wetland class.

a. Emergent marsh and/or shallow open water

b) Forested and/or scrub-shnub wetland 0.5

c. Scrub-shrub saturated $(b 0 g)$ or wet meadow

6. Interspersion of vegetation classes and/or open water.

a. At least two wetland classes highly interspersed. Areas of each class scattered within wetland like a patchwork quith

b. Moderate interspersion of wetland 0.5 classes

c. Low degree of interspersion. Each 0.1 wetland class is more or less contiguous and separate from the other classes 
WETLAND WILDLIFE HABITA

(continued)

\begin{tabular}{cccc}
\hline A & $B$ & $C$ & $D$ \\
Evaluation & Computations & Evaluation & Functional Value \\
Questions & or Actual Value & Criteria & index (FVI) \\
\hline
\end{tabular}

7. Wetland juxtaposition.

a.

Wetland connected 10 other wellands within a 1 mile radius by perennial stream or lake

b. Wetland connected to other wellands within a 1 to 3 mile radius by perennial stream or lake, OR other unconnected wellands are present within a 1 mile radius

c. Wetland not hydrologically connected to other wetlands within 3 miles and no other unconnected wetlands within 1 mile

8. Number of islands or inclu-

a. Two or more sions of upland within wetland.

b. One

c. None

9. Wildlife access to other wetlands (overland). Travel lanes should be 50-100 leet wide.

a. Free access abng well vegetated stream corridor, woodland, or lakeshore

b. Access partially blocked by roads, urban areas, or other obstructions

c. Access blocked by roads, urban areas, or other obstruc. tions

10. Percent of welland edge bordered by upland wildite habitat (brush, woodland,

AVERAGE FVI FOR FUNCTIONAL VALUE $2=$ AVerage of column D $=.498 \cdot(4.983-10)$ EVALUATION AREA FOR FUNCTIONAL VALUE 2 - Total area of wetland = 3 acres. 


\section{5, Marh}

SUMMARY SHEET FOR THE N.H. METHOD res/07atiTT

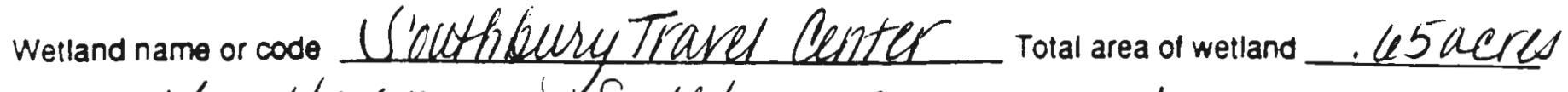

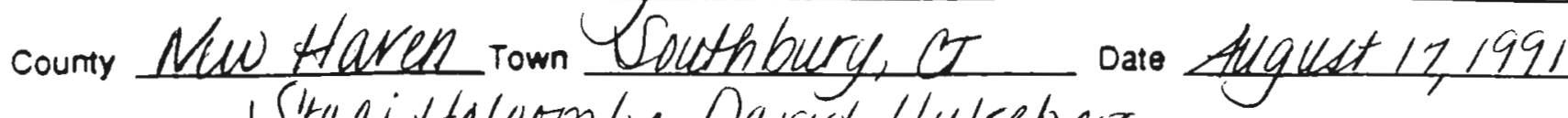

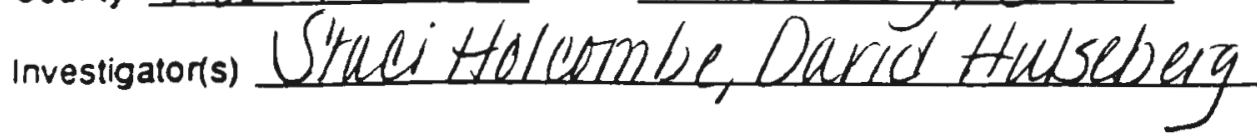

\begin{tabular}{|c|c|c|c|}
\hline $\begin{array}{c}\text { A } \\
\text { Functlonal } \\
\text { Value }\end{array}$ & $\begin{array}{c}\text { B } \\
\text { FVI From } \\
\text { Data Sheets }\end{array}$ & $\begin{array}{c}\text { C } \\
\text { Slze of Evaluation } \\
\text { Area (Acres) }\end{array}$ & $\begin{array}{c}D \\
\text { Wetland Value Units } \\
B \times C\end{array}$ \\
\hline 1. Ecological Integrity & .525 & .65 & 1341 \\
\hline 2. Wildlife Habitat & .463 & $.165^{-}$ & 301 \\
\hline $\begin{array}{l}\text { 3. Finfish Habitat: } \\
\text { Pan A - Rivers and Streams }\end{array}$ & & t & .642 \\
\hline Pant B - Ponds and Lakes & & & \\
\hline
\end{tabular}

4. Educational Potential

5. VisuaVAesthetic Ouality

6. Water Based Recreation

7. Flood Control Potential

8. Ground Water Use Potential

9. Sediment Trapping

10. Nutriem Attenuation

11. Shoreline Anchoring and

Dissipation of Erosive Forces

12. Urban Quality of Life

B: Wildlife Habitat

C: Educational Oppontunity

D: VisuaVAesthetic Quality

E: Water Based Recreation

13. Historical Site Potential

14. Noteworthiness 
NEEDED FOR THIS EVALUATION:

- Zoning má

- SCS soils map

- N.H. Water Quality Report to Congress 305(b)

- USGS topographic map or recent aerial pholograph

- A method to calculate area (Dot grid, planimeter, etc.)

- Ruler or scale

- Map wheel (Optional)

\section{A}

Evaluation

Questions
Soutiousy Havel Center 245

Functional Value 1

ECOLOGICAL INTEGRITY

\section{QUESTIONS TO ANSWER IN THE OFFICE:}

1. Percent of wetland having very poorly drained soils or Hydric A soils and/or open

2. Dominant land use zoning of welland (see town zoning map). Use current land use if different from what is zoned. water.
Evaluation Criteria
Functional Valu Index (FVI)

$$
\begin{aligned}
& R b, A f A, U D, N n \\
& 0 \text { hydne (most of dite is this } \\
& \text { solitype) }
\end{aligned}
$$

BLE-busines a. More than 50 percent 1.0

o. From 25 to 50 percent 0.5

c. Less than 25 percent 0.1

a. Agriculture, forestry, or $\quad 1.0$ similar open space zoning

b. Aural residential

c. CommerciaVindustrial, high density residential

\section{QUESTIONS TO ANSWER IN THE FIELD:}

3. Water quality of the watercourse, pond, or lake associated with the wetland.

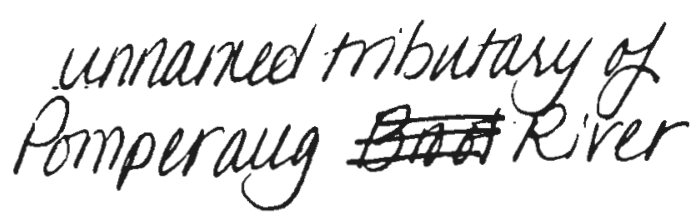

4. Ratio of the number of occupied buildings within 500 feet of the wetland edge $\sim 9: 1 a c$ to the total area of the wetland (acres).

5. Percent of original wetland filled. a.)

$$
\begin{aligned}
& \text { a. } \\
& \text { b. }
\end{aligned}
$$

High: Minimal pollution Actual water quality meets or exceeds Class A or B standards

b. Medium: Moderate pollution. Actual water quality is below Class B standards

a. Less than 1 bldg: $\quad 1.0$ 10 acres $(<0.10)$

b. From 1 bidg: 10 acres to 0.5 1 bldg: 2 acres 10.10 . $0.50)$

c. More than 1 bidg: 2 acres (>0.5)

a. Less than 10 percent $\quad 1.0$

b. From 10 to 50 percent 0.5 c. More than 50 percent 0.1

6. Percent of wetland edge bordered by a butfer of woodland or idle land at least 500 leet in width. a. More than 80 percent 1.0

b. From 20 to 80 percent 0.5

c. Less than 20 percent

a. Low level: Few trails in $\quad 1.0$ use andor sparse litter

b. Moderate level: Some used trails, roads, etc.

c. High level: Many trails, roads, elc. within wetland 


\begin{tabular}{cccc}
\hline A & $B$ & $C$ & $D$ \\
$\begin{array}{c}\text { Evaluation } \\
\text { Questions }\end{array}$ & $\begin{array}{c}\text { Computations } \\
\text { or Actual Value }\end{array}$ & $\begin{array}{c}\text { Evaluation } \\
\text { Criteria }\end{array}$ & $\begin{array}{c}\text { Functional Valt } \\
\text { Index (FVI) }\end{array}$ \\
\hline
\end{tabular}

QUESTIONS TO ANSWER IN THE FIELD (continued):

8. Level of human activity IN UPLAND within 500 feet of the wetland edge as evi denced by litter, bike trails. roads, residences, etc. surrounded ay travel center and radson all sides a. Low level: Few trails in use $\quad 1.0$ and/or sparse litter

b. Moderate level: Some trails, 0.5 scattered residences, etc.

c. High level: Many trails,
roads, etc. within upland

1.0

0.5

0.1 a. Less than 10 percent b. From 10 to 50 percent altered by mowing, grazing. farming, or other activity. (Include areas now dominated by phragmites or purple bosestrite).

mowing of the ap tand edges of the wettand, mach of the southwertern wetlands full of priagmites (uominant)

10. Percent of wetland actively being drained for agriculture or other purposes.

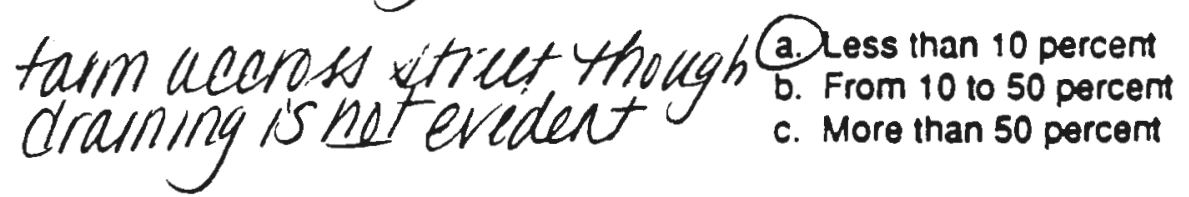

11. Number of public road and/or railroad crossings per 500 feet of wetland (measured along long axis of wetland).

oxlyou road is adjacent t parallel a. None

6. One or fewer

C. Two or more

a. Wetland appears to be naturally occurring, not
impounded by dam or dike

b. Wetland appears to be somewhat dependent on artiticial diking by dam. road, fill, etc.

up 07 kills. Appears. Hiat lilat

runotf from suthoulding area would end up diaining to here.

AVERAGE FVI FOR FUNCTIONAL VALUE $1=$ AVerage of column D $=.525 .(6.3-12)$

EVALUATION AREA FOR FUNCTIONAL VALUE 1 - Total area of welland acres. 


\section{NEEDED FOR THIS EVALUATION:}

- USGS lopographic map

- Land use map and/or recent aerial photographs

- Ruler or scale

- A method to calculate area (Dot grid, planimeter, etc.)

- N.H. Water Quality Reporn 10 Congress 305(b)
Shuthbury Tiarel Cerite

\section{A}

Evaluation

Questions
Computations

or Actual Value
C

Evaluation

Criteria
D

Functional Valu Index (FVI)

\section{QUESTIONS TO ANSWER IN THE OFFICE:}

1. Ecological integrity.

2. Area of shallow permanem open water (less than 6 feet deep) including streams

in or adjacent to wetland.
Average FVI from Functional Value 1
2. More than 3 acres
b. From 0.5 to 3 acres
c. Less than 0.5 acre

3. Water quality of the watercourse, lake, or pond associated with the wetland.

4. Welland diversity.

a. Three or more wetland classes present

5. Dominant wetland class.

a. Emergent marsh and/or shallow open water

b. Forested and/or scrub-shnub welland

0.5

c. Scrub-shnub saturated (bog) or wet meadow

6. Interspersion of vegetation classes and/or open water.

a. At least two wetland classes highly interspersed. Areas of each class scattered within wetland like a patchwork quilt

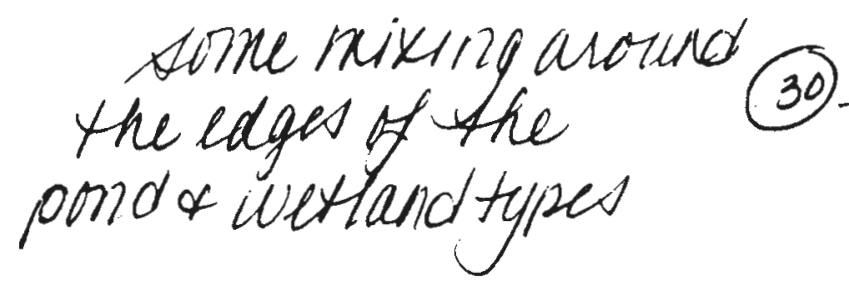

b. Moderate interspersion of welland

classes

c. Low degree of imterspersion. Each wetland class is more or less contiguous and separate from the other classes 
WETLAND WILDLIFE HABITAi

(comtinued)

\begin{tabular}{cccc}
\hline Evaluation & $\mathbf{B}$ & $\mathrm{C}$ & $\mathrm{D}$ \\
Questions & Computations & Evaluation & Functional Value \\
Index (FVI) & Criteria & octual Value & Index (FV \\
\hline
\end{tabular}

7. Welland juxtaposition.

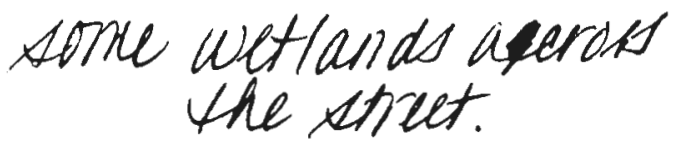

8. Number of islands or inclusions of upland within wetland.

9. Wildlife access to other wetlands (overland). Travel lanes should be 50.100 leet wide. a. Welland connected to other wetlands within a 1 mile radius by perennial stream or lake

b. Welland connected to other wetlands within a 1 to 3 mile radius by perennial stream or lake, OR other unconnected wetlands are present within a 1 mile radius

c. Wetland not hydrologically connected to other wetlands within 3 miles and no other unconnected wetlands within 1 mile
a. Two or more
b. One
c. None

1.0

0.5

a. Free access abng well vegetated stream corridor. woodland, or lakeshore

b. Access partially blocked by roads, urban areas, or other obstructions

c. Access blocked by roads, urban areas, or other obstruc. tions

a. More than 40 percent bordered by upland wildite habitat (brush, woodland, active farmland, or idle land) c. Less than 10 percent at least $\mathbf{5 0 0}$ feet in width.

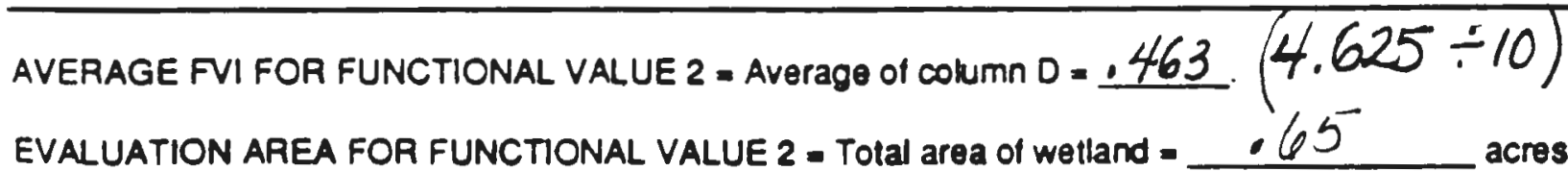
acres. 


\section{SUMMARY SHEET FOR THE N.H. METHOD}

Welland name or code Sollth buly Truvel Af (Comtid) Total area or welland 2.25 ace county New Haren Town Southbury, CT Dato septenbes 20,199

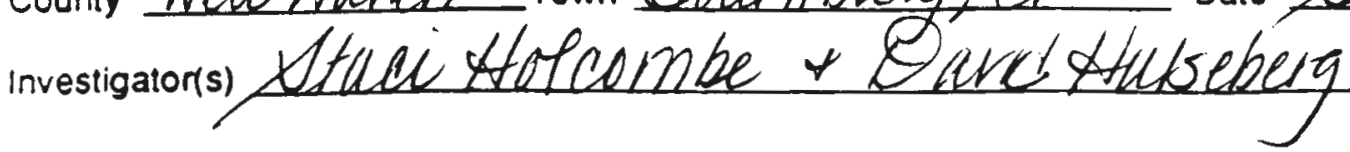

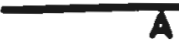

Functlonal

Value

1. Ecological integrity

2. Wildlife Habitat

.643

3. Finfish Habitat:

Part A - Rivers and Streams

Pant $B$ - Ponds and Lakes
B

FVI from

Data Sheots
Size of Evaluation

Area (Acres)
D

Wetland Value Units

$\mathrm{B} \times \mathrm{C}$
.725

1.25

.906

1.25

$\frac{.804}{1.710}$

4. Educational Potential

5. VisuaVAesthetic Quality

6. Water Based Recreation

7. Flood Control Potential

8. Ground Water Use Potential

9. Sediment Trapping

10. Nutriem Attenuation

11. Shoreline Anchoring and

Dissipation of Erosive Forces

12. Urban Quality of Life

B: Wildife Habitat

C: Educational Opportunity

$D$ : VisuaVAesthetic Quality

E: Water Based Recreation

13. Historical Site Potential

14. Noteworthiness 


\section{NEEDED FOR THIS EVALUATION:}

- Zoning mã̃

- SCS soils map

- N.H. Water Quality Report to Congress 305(b)

- USGS topographic map or recent aerial pholograph

- A method to calculate area (Dot grid, planimeter, etc.)

- Ruler or scale

- Map wheel (Optional)

- Map wheel (Oplion

Evaluation

(off Hollow Suane koad)

Questions
Computations

or Actual Value
Functional Value 1 ECOLOGICAL INTEGAITY

QUESTIONS TO ANSWER IN THE OFFICE:

1. Percent of welland having very poorly drained soils or Hydric A soils and/or open water.

2. Dominant land use zoning of wetland (see town zoning map). Use current land use if differem from what is zoned.

\section{QUESTIONS TO ANSWER IN THE FIELD:}

3. Water quality of the watercourse, pond, or lake associated with the wetland.

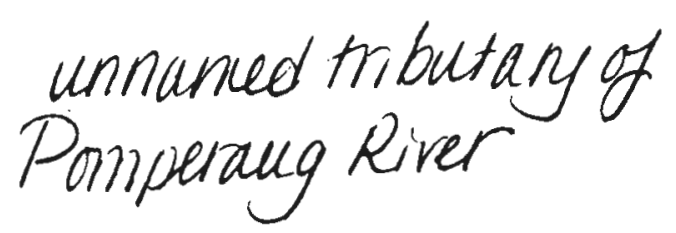

4. Ratio of the number of occupied buildings within 500 feet of the wetland edge to the lotal area of the wetland (acres).

5. Percent of original wetland filled.

6. Percent of welland edge bordered by a butfer of woodland or idle land at least 500 feet in width.

$$
\begin{aligned}
& \text { AFB, AA, HSE } \\
& \text { Ahydrie (mistly } \\
& \text { Uhis soll type) }
\end{aligned}
$$

B2E- GWAINES a More than 50 percent

b. From 25 to 50 percent

c. Less than 25 percent

1.0

0.5

0.1

a. Agriculture, forestry, or similar open space zoning

b. Rural residential

c. Commercialindustrial, high density residential

(a.)

High: Minimal pollution. Actual water quality meets or exceeds Class $A$ or B standards

b. Medium: Moderate pollution. Actual water quality is below Class B standards

a. Less than 1 bldg: 10 acres $(<0.10)$

b. From 1 bldg: 10 acres to 1 bldg: 2 acres $(0.10$ -

c. More than 1 bldg: 2 acres $(>0.5)$ 


\begin{tabular}{|c|c|c|c|}
\hline $\begin{array}{c}\text { A } \\
\text { Evaluation } \\
\text { Questions }\end{array}$ & $\begin{array}{c}8 \\
\text { Computations } \\
\text { or Actual Value }\end{array}$ & $\begin{array}{c}\text { C } \\
\text { Evaluation } \\
\text { Criteria }\end{array}$ & $\begin{array}{c}\text { Functional Va:t } \\
\text { Index (FVI) }\end{array}$ \\
\hline
\end{tabular}

QUESTIONS TO ANSWER IN THE FIELD (continued):

8. Level of human activity IN UPLAND within 500 feet of

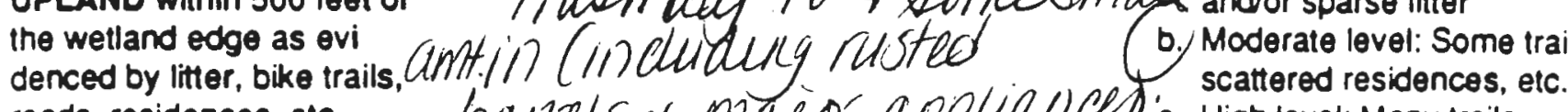

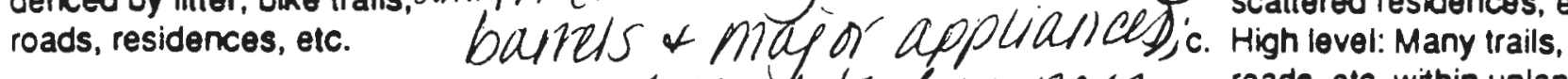
acess had to beerress roads, etc. within upland

9. Percent of wetland plant community presently being altered by mowing, grazing, farming, or other activity.

(a. Less than 10 percent

b. From 10 to 50 percent

0.5 (Include areas now dominated

c. More than 50 percent by phragmites or purple losestrite).

10. Percent of wetland actively being drained for agricutture

a. Less than 10 percent being drained for agrix
or other purposes.

b. From 10 to 50 percent

c. More than 50 percent

Number of public road and/or railroad crossings per 500 leet of wetland (measured along long axis of wetland).

12. Long-term stability.

a. Welland appears to be
naturally occurring, not impounded by dam or dike

b. Welland appears to be somewhat dependent on artificial diking by dam. road, fill, etc.

AVERAGE FVI FOR FUNCTIONAL VALUE $1=$ Average ol column $0=.725 \cdot(8.7 \div 12)$ EVALUATION AREA FOR FUNCTIONAL VALUE $1=$ Total area of wetland $=1.25$ acres. 


\section{NEEDED FOR THIS EVALUATION:}

- USGS topographic map

- Land use map andjor recent aerial photographs

- Ruler or scale

- A method to calculate area (Dot grid, planimeter, etc.)

- N.H. Water Quality Report to Congress 305(b)

\begin{tabular}{|c|c|c|c|}
\hline $\begin{array}{c}\text { A } \\
\text { Evaluation } \\
\text { Questions }\end{array}$ & $\begin{array}{c}\text { B } \\
\text { Computations } \\
\text { or Actual Value }\end{array}$ & $\begin{array}{c}\mathrm{C} \\
\text { Evaluation } \\
\text { Criteria }\end{array}$ & $\begin{array}{c}D \\
\text { Functionie valu } \\
\text { Index }=. \cdots\end{array}$ \\
\hline
\end{tabular}

\section{QUESTIONS TO ANSWER IN THE OFFICE:}

1. Ecological integrity.

2. Area of shallow permanent open water (less than 6 feet deep) including streams in or adjacent to wetland.
Average FVI from Functional Value 1

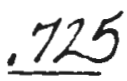
a. More than 3 acres
b. From 0.5 to 3 acres
c. Less than 0.5 acre

10

05

0 :

\section{QUESTIONS TO ANSWER IN THE FIELD:}

3. Water quality of the watercourse,

FVI from Question V.1.3 lake, or pond associated with the wetland.

4. Wetland diversity.
a. Three or more wetland classes
present
(b Two wetland classes present
0.5
c. One wetland class present

5. Dominant wetland class.

a. Emergent marsh and/or shallow open water

b. Forested and/or scrub-shrub wetland

0.5

c. Scrub-shrub saturated (bog) or wet meadow

6. Interspersion of vegetation classes and/or open water.

a. At least two wetland classes highly interspersed. Areas of each class scattered within wetland like a patchwork quith

b. Moderate interspersion of wetland classes

c. Low degree of interspersion. Each welland class is more or less con. tiguous and separate from the other classes 
WETLAND WILDLIFE HABITA

(continued)

\begin{tabular}{cccc}
\hline A & 8 & $C$ & $D$ \\
Evaluation & Computations & Evaluation & Functional Value \\
Questions & or Actual Value & Criteria & Index (FVI) \\
\hline
\end{tabular}

7. Wetland juxtaposition.

8. Number of islands or inclusions of upland within wetland.

9. Wildlife access to other wellands (overland). Travel lanes should be 50.100 leet wide.

10. Percent of wetland edgs bordered by upland wildile habitat (brush, woodland, active farmland, or idle land) at least 500 foet in width. a. Wetland connected to other 1.0 wetlands within a 1 mile radius by perennial stream or lake

b. Wetland connected to other wetlands within a 1 to 3 mile radius by perennial stream or lake, OR other unconnected wetlands are present within a 1 mile radius

c. Wetland not hydrologically connected to other wellands within 3 miles and no other unconnected wetlands within 1 mile

a. Two or more $\quad 1.0$

b. One

0.5

c. None

a. Free access along well $\quad 1.0$ vegetated stream comidor, woodland, or lakeshore

b. Access partially blocked by roads, urban areas, or other obstructions

c. Access blocked by roads, urban areas, or other obstruc. tions

a. More than 40 percent

c. Less than 10 percemt

\footnotetext{
AVERAGE FVI FOR FUNCTIONAL VALUE $2=$ AVerage of column D $=.643(6,425 \div 10)$

EVALUATION AREA FOR FUNCTIONAL VALUE $2=$ Total area of wetland $=1,25$ acres.
} 
Appendix B

\section{PERMITS}




\section{DEPARTMENT OF THE ARMY PERMIT}

Permittee Rhode Island Dept. of Transportation, James R. Capaldi, State Office Building, Providence, Rhode Island 02903

Permit No. RI-PAWT-87-04/ APPLICATION NUMBER: $12-86-852$

Issuing Office New England Division

NOTE: The term "you" and its derivatives, as used in this permit, means the permittee or any future transferee. The term "this office" refers to the appropriate district or division office of the Corps of Engineers having jurisdiction over the permitted activity or the appropriate official of that office acting under the authority of the commanding officer.

You are authorized to perform work in accordance with the terms and conditions specified below.

Project Description:

place fill in waters and wetland in conjunction with the construction of the Woonsocket Industrial Highway, Route 99. The project involves the placement of fill material within 5 freshwater wetland sites adjacent to the crook Fall Brook totaling 7.2 acres. In addition, temporary fill will impact 0.2 acres of wetland adjacent to the Blackstone River. Approximately 141,200 cubic yards of fill will be placed within the 5 wetland areas whereas, approximately 770 cubic yards of temporary fill will be placed below ordinary high water in order to facilitate bridge construction across the Blackstone River. In accordance with the atcached plans entitled "Woonsocket Industrial Highway/Route 99 at Cumberland, Lincoln, Woonsocket, Providence County, State of Rhode Island" in 18 sheets dated $1 / 5 / 87$.

Project Location:

In wetlands adjacent to Crook Fall Brook and the Blackstone River At Lincoln and Cumberland, Rhode Island

Permit Conditions:

General Conditions:

1. The time limit for completing the work authorized ends on December 31, 1990 . If you find that you need more time to complete the authorized activity, submit your request for a time extension to this office for consideration at least one month before the above date is reached.

2. You must maintain the activity authorized by this permit in good condition and in conformance with the terms and conditions of this permit. You are not relieved of this requirement if you abandon the permitted activity, although you may make a good faith transfer to a third party in compliance with General Condition 4 below. Should you wish to cesse to maintain the authorized activity or should you desire to abandon it without a good faith transfer, you must obtain a modification of this permit from this office, which may require restoration of the ares.

3. If you discover any previously unknown historic or archeological remains while accomplishing the activity authorized by this permit, you must immediately notify this office of what you have found. We will initiate the Federal and state coordination required to determine if the remains wartant a recovery effort or if the site is eligible for listing in the National Register of Historic Places. 
4. If you sell the property associated with this permit, you must obtain the signature of the new owner in the space provided and forward a copy of the permit to this office to validate the transfer of this authorization.

5. If a conditioned water quality certification has been iscued for your project, you must comply with the conditions specified in the certification as special conditions to this permit. For your convenience, a copy of the certification is attached if it contains such conditions.

6. You must allow representatives from this office to inspect the authorized activity at any time deemed necessary to ensure that it is being or has been accomplished in accordance with the terms and conditions of your permit.

Special Condition:

1. All areas of wetlands which are disturbed during construction shall be restored to their approximate original elevation (but not higher) and condition by careful protection, and or removal, and replacement of existing soil and vegetation. In addition, if upland clearing, grubbing or other construction activity rasults in or may result in soil erosion with transport and deposition into wetland, devices such as hay bales, sediment trenches, etc., shall be installed and properly maintained to minimize such impacts during construction. These devices must be removed when no longer needed.

Further Information:

ISPECIAL CONDITIONS CONTINUED ON PAGE 4

1. Congressional Authorities: You have been authorized to undertake the activity described above pursuant to:

( ) Section 10 of the Rivers and Harbors Act of 1899 (33 U.S.C. 403).

(x) Section 404 of the Clean Water Act (33 U.S.C. 1344).

( ) Section 103 of the Marine Protection, Research and Sanctuaries Act of 1972 (33 U.S.C. 1413).

2. Limits of this authorization.

a. This permit does not obviate the need to obtain other Federal, state, or local authorizations required by law.

b. This permit does not grant any property rights or exclusive privileges.

c. This permit does not authorize any injury to the property or rights of others.

d. This permit does not authorize interference with any existing or proposed Federal project.

3. Limit of Federal Liability. In issuing this permit, the Federal Government does not assume any liability for the following:

a. Damages to the permitted project or uses thereof as a result of other permitted or unpermitted activities or from natural causes.

b. Damages to the permitted project or uses thereof as a result of current or future activities undertaken by or on behalf of the United States in the public interest.

c. Damages to persons, property, or to other permitted or unpermitted activities or structures caused by the activity authorized by this permit.

d. Design or construction deficiencies associated with the permitted work. 
e. Damage claims associated with any future modification, suspension, or revocation of this permit.

4. Reliance on Applicant's Data: The determination of this office that issuance of this permit is not contrary to the public interest was made in reliance on the information you provided.

5. Reevaluation of Permit Decision. This office may reevaluate its decision on this permit at any time the circumstances warrant. Circumstances that could require a reevaluation include, but are not limited to, the following:

2. You fail to comply with the terms and conditions of this permit.

b. The information provided by you in support of your permit application proves to have been false, incomplete. or inaccurate (See 4 above).

c. Significant new information surfaces which this office did not consider in reaching the original public interest decision.

Such a reevaluation may result in a determination that it is appropriate to use the suspension, modification, and revocation procedures contained in 33 CFR 325.7 or enforcement procedures such as those contained in 33 CFR 326.4 and $326 . \pm$. The referenced enforcement procedures provide for the issuance of an administrative order requiring you to comply with the terms and condition of your permit and for the initiation of legal action where appropriate. You will be required to pay for any corrective measures ordered by this office, and if you fail to comply with such directive, this office may in certain situations (ouch as those specified in 33 CFR 209.170) accomplish the corrective measures by contract or otherwise and bill you for the cost.

6. Extenuion. General condition 1 establishes a time limit for the completion of the activity authorized by this permit. Cniese there are circumstances requiring either a prompt completion of the authorized activity or a reevaluation of the public interest decision, the Corps will normally give favorable consideration to a requeat for an extension of this time limit.

Your signature below, as permittee, indicates that you accept and agree to comply with the terms and conditions of this permit.
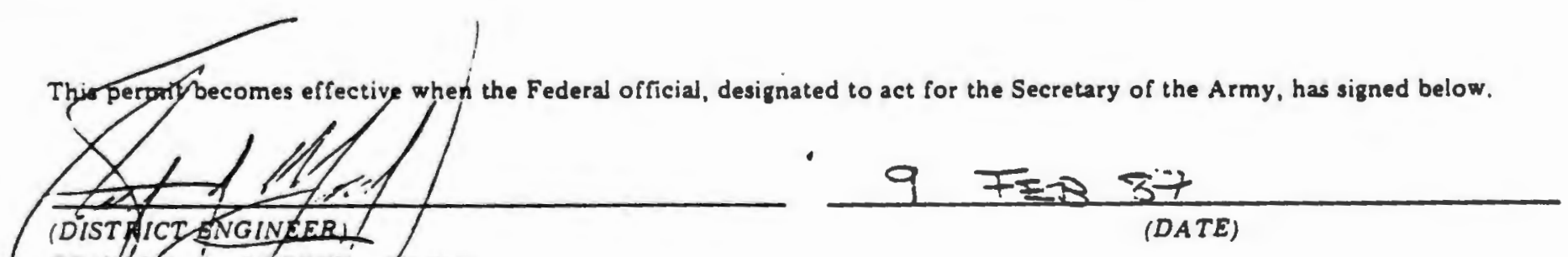

STAYRY \$. MURPHY, MAAJOR

(DATE) 


$\frac{23-85-610}{81 \text { ganl Eavironmentel syotem, Inc. }}$

Expiration Dato (I/ appllioblo)

\section{DEPARTMENT OF THE ARMY PERMIT}

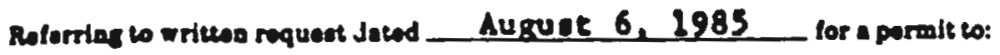

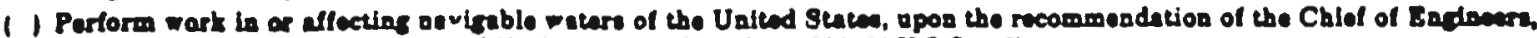
purouent wo Soctoa 10 of the Rivers and Harbors Aet of Mareb S. 2090 iss U.S.C. task

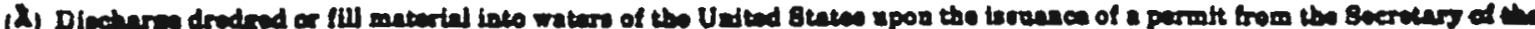

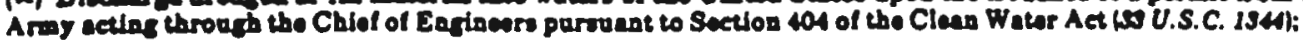

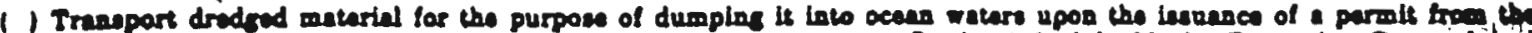

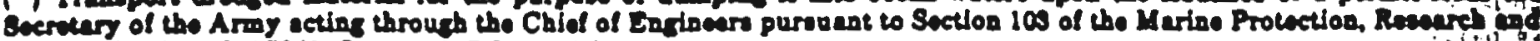

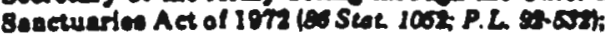

Slganl suvironoental syotems, Ine. Liberey Lane

Hempeo, New Himpatize 03842

en

Lo heroby authorized by the Secrotery of the Army: to

place apprósimetely 400 cuble yarde of metertal into a 21,300 eq. fe. weland ares in order to construct a colld wate resource recovery facllity. In idditión - 25,000 eq. It. wetland ares will be created, a companeatlon for the welmda being Illied.

N

6.)

In

tributary to Broed Madow Brook

$\ldots+\cdots$

2.

af Mllibury, Maseachusetcs

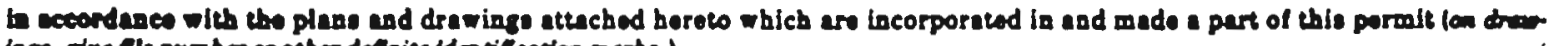

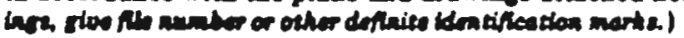

"Millbury Resource Recovery Recilley"

In 4 undated theets.

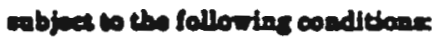

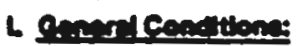

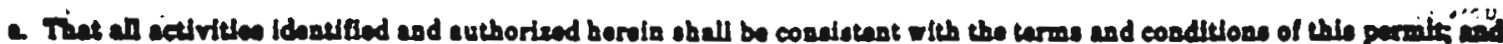

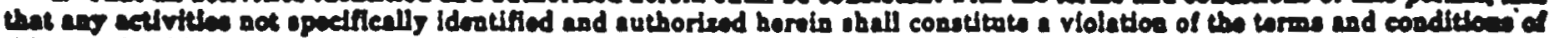

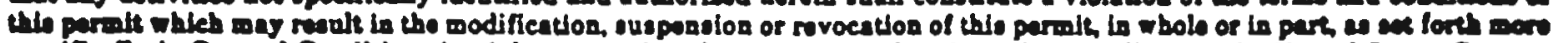

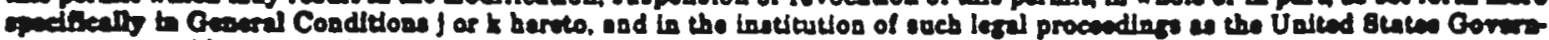

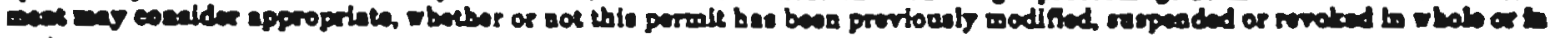
iant

ENO FOAM 1721, SOP 82

EDTON of I JUL $n$ w OASOLTE

ailcision.

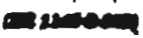




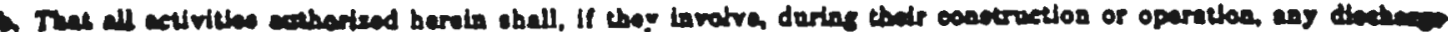

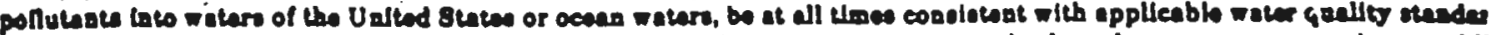

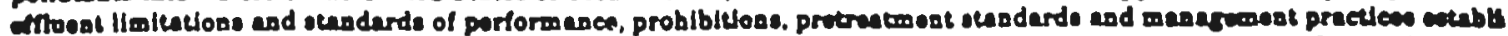

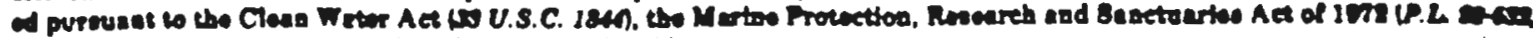

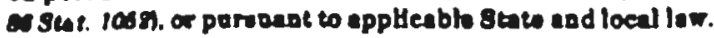

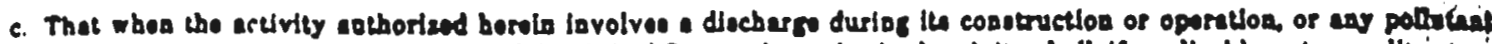

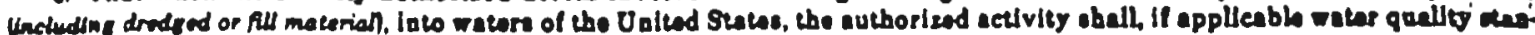

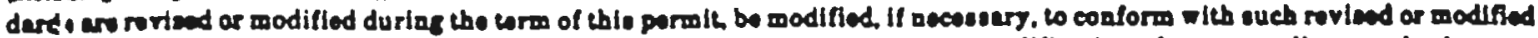

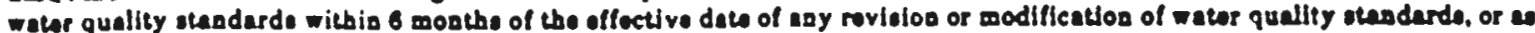

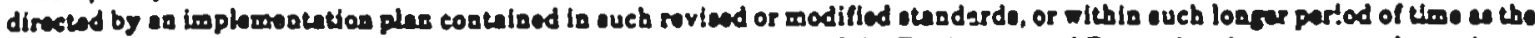

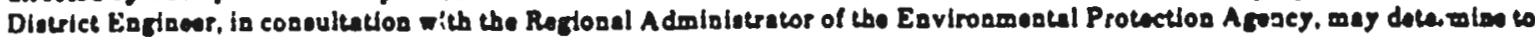
be reasonablo under the cireumataneas.

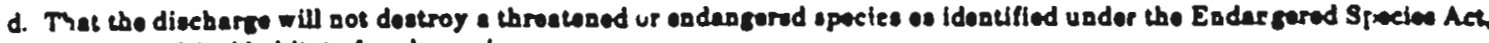
or endanger the crillical habitat of such epecioe.

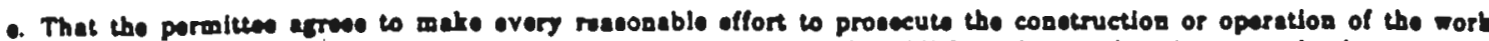

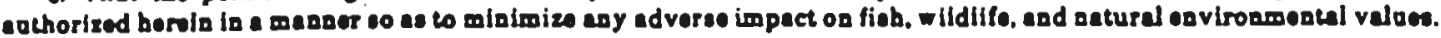

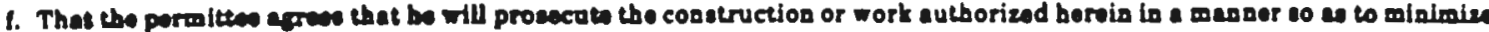
any derradotion of mater quality.

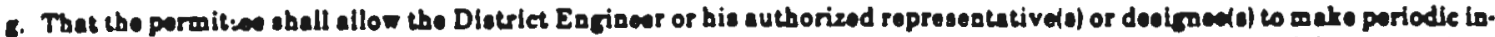

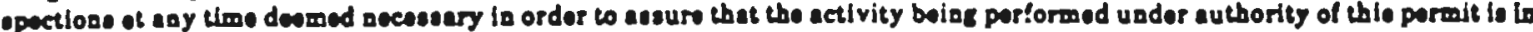
accordances with the torms and conditlone preseribod borin.

in

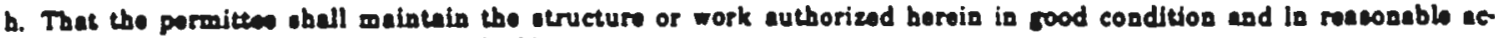
cordence with the plane and draninge atuebed boroto.

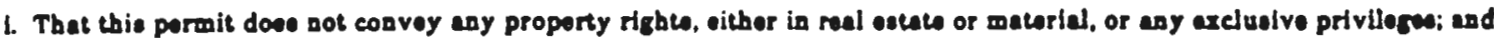
that it does con authories any lojury to proporty or invajios of righen of any infriagement of Fedaral. State, or local lawt of ropulaticos.

1. That this permit does not obviate the requiremeat wo oblain atate or locel asenat required by lew for the cecivity autboris. ad berala.

k. That this parmit may be oithor modified. ousponded of sovoked in whole or is part puraune to the polleteo asd procodures of 3S CFR 326.7.

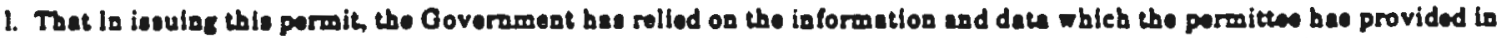

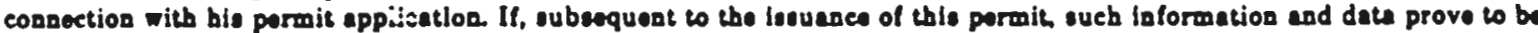

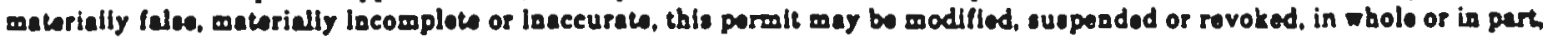
and/or tho Goverament may, in addition, Inetitute appropriate lagel procendioge.

m. That any modification, ounpension, or rovocation of this permit shall aot be the banie for any claim for damages seainat the Uaitad States.

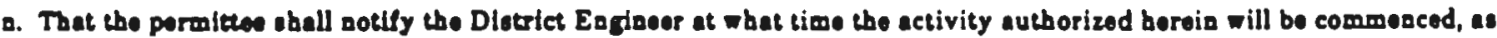
far is advance of the timo of commencement as the Dlotrict Enginear may apocify, and of any suspenslon of work, If for a pariod of more than one week, resumption of work and ite complotion.

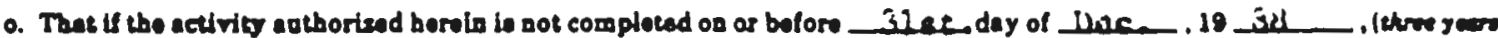

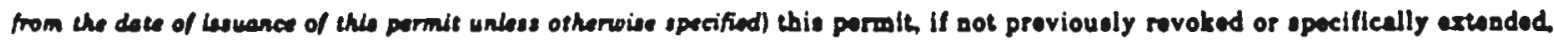
iball automatically expirs.

p. That this parmit does not authorize or approve the cosetruction of perticular acructures, the euthorization of approvel of which may requils autbortzation by the Congross or otber egencioe of the Federal Government.

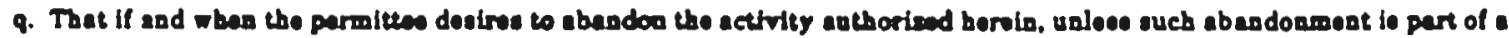

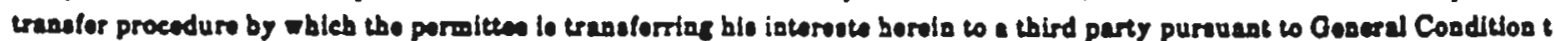
boreof, bo muat rentore tho area to e cosdition entisfectory wo the District Engioces.

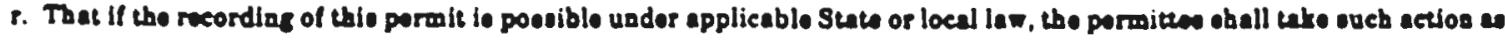

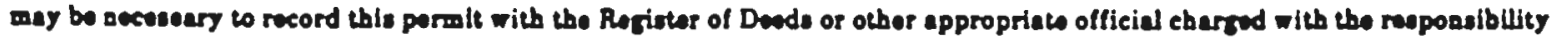
for maintaialng recorde of vitlo to and intarests io real proparty. 


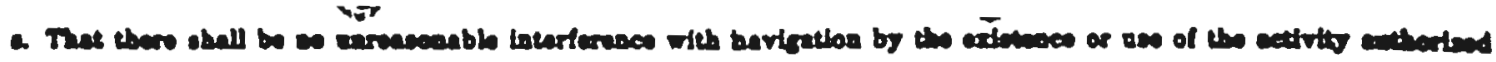
sand.

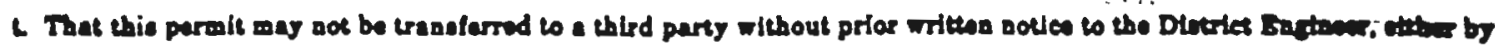

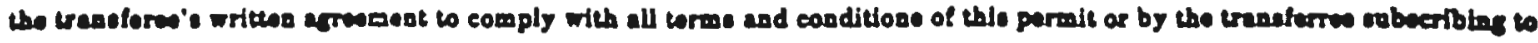

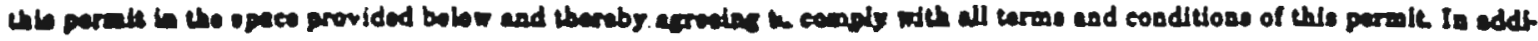

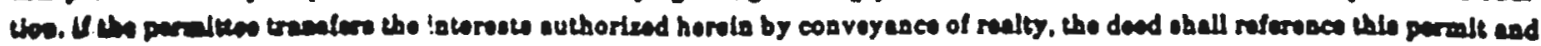

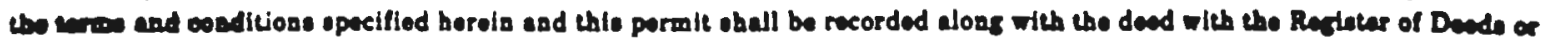
other epproprtat official

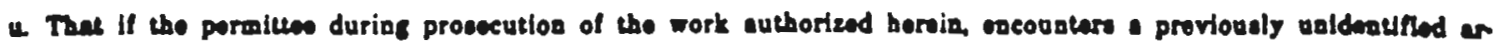

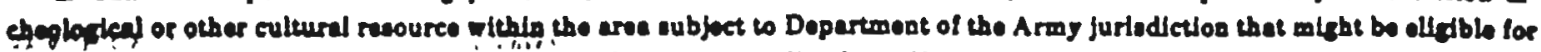

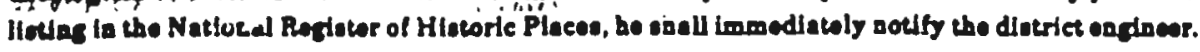

$\therefore, \ldots, \cdots$

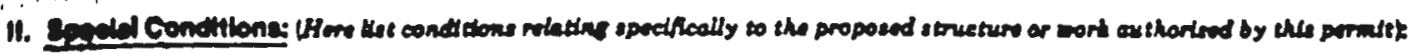

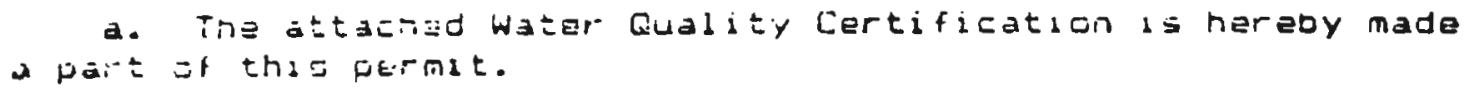

b. A 25, J00 square foot wetland araa will be created,as. comperisation for the wetlands being flliej. 


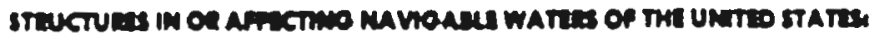

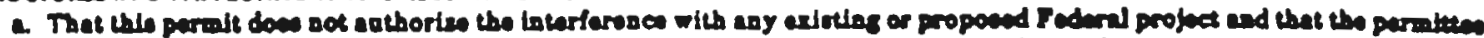

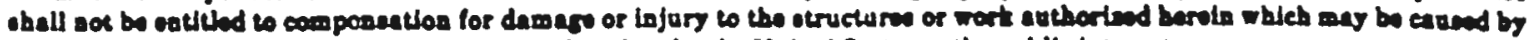

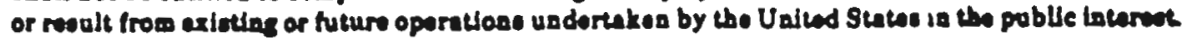

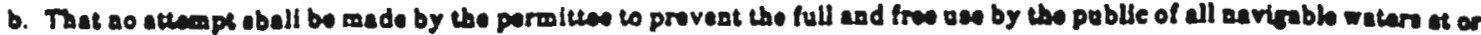
adjecent to the activity suthoriand by this pormile.

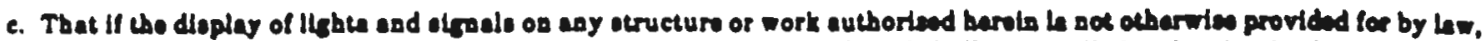

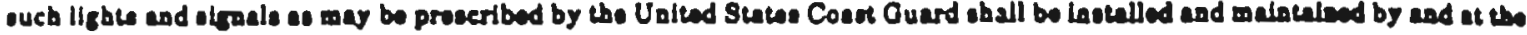
expeses of che parmiltare.

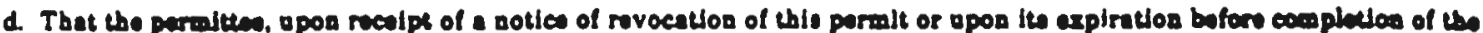

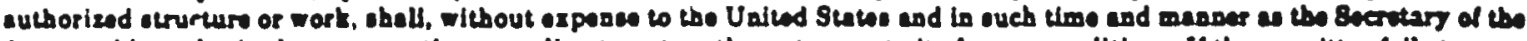

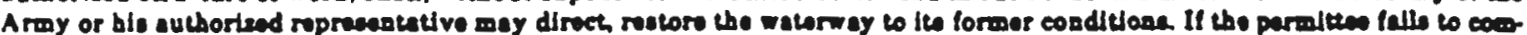

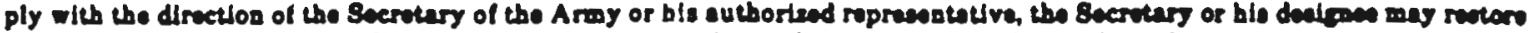

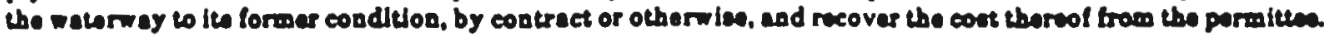

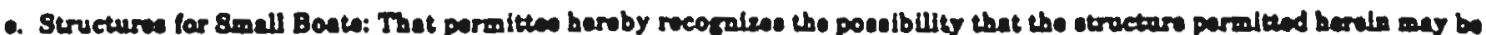

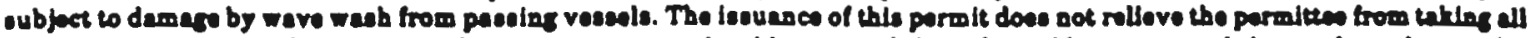

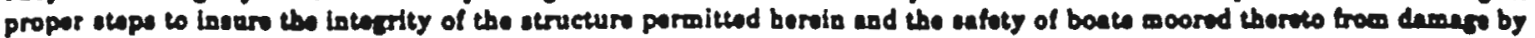

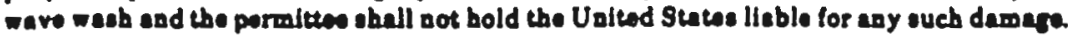

\section{MaimThanca Disocines}

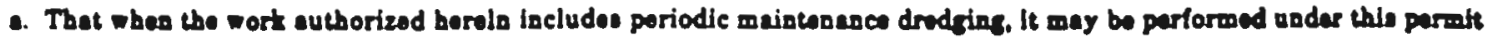
tor.

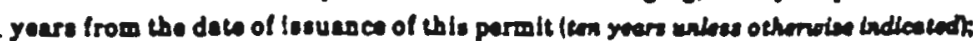

b. That the parsitten will advies the Dintrict Eagisear in writing at leant two weeks bofore bo lotoude lo undartake any melntaner se drodelas.

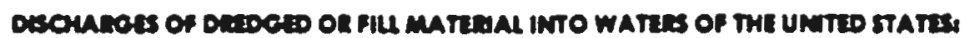

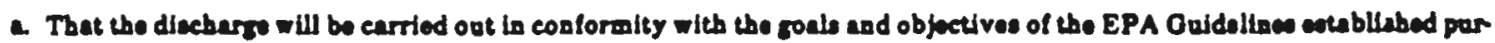
ourat wo Saction 404b) of the Cleen Watar Act and publlabed in 40 CFR 230;

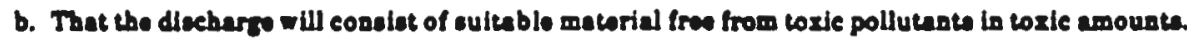

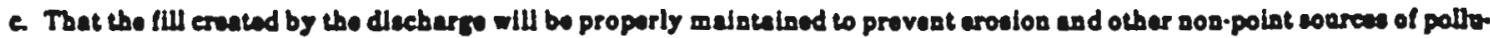
in doe.

42

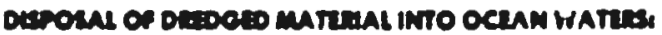

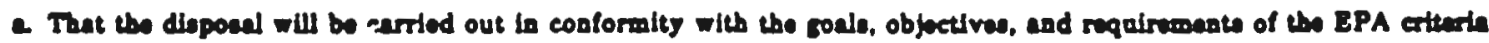

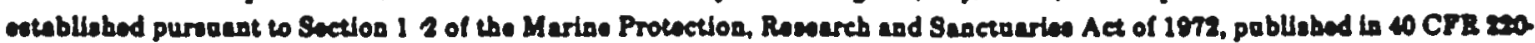
202.

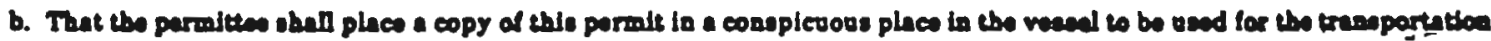
and/or disposel of the drodend wetarial as autboriead berole.

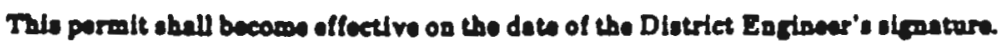

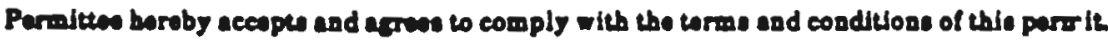
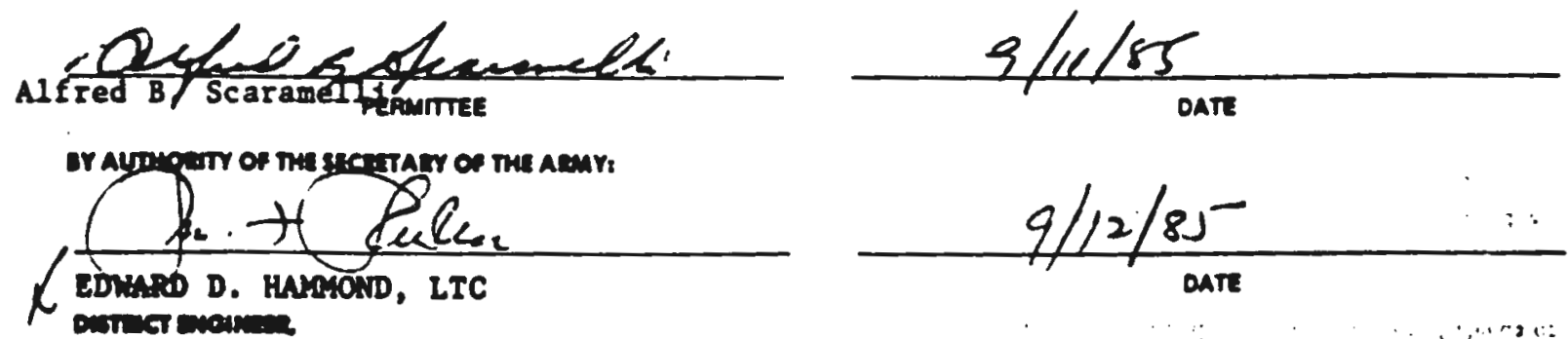

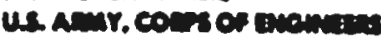

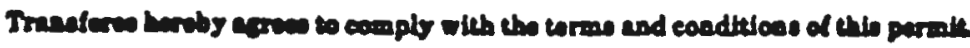

Thumbrente
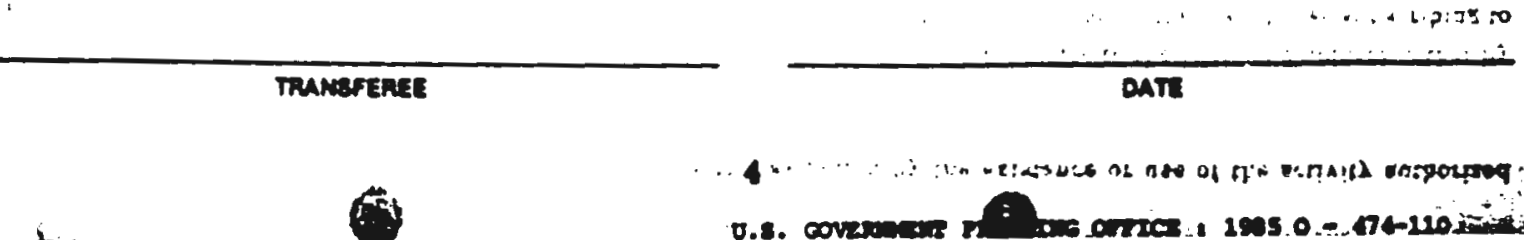

(1)

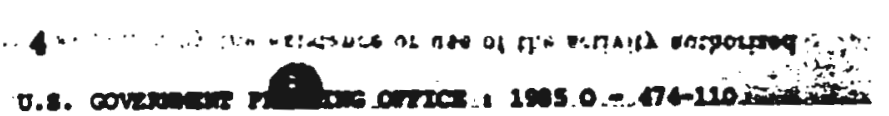


Permilee $\frac{\text { Stephen Barton, Connecticut Dept. ul Wrarsportation }}{\text { P.O. Drawer A, wetherstield, CT 06109-0801 }}$

Permit No. CTATPLICATIOIN NLMBER: $\quad 14-85-871-88-\alpha$

Isuing Orfice New England Division

NOTE: The tem "you" and th derivatives, as used in this permit, means the permillee or any future trancieree. The term "this office" refere to the appropriate district or division sffice of the Corps of Engireen having jurisdiction over the permitted activity or the appropriate official of that office acting under the authority of the commanding officer.

You are authorized to perform work in accordance with the terms and conditions opecified below.

Project Deacription :

This project is the second in a series to complete the relocation of Route 7 from Norwalk to Danbury, Connecticut. This permit authorizes the placement of fill material within 10 freshwater wetland sites, totalling 7.8 acres. In addition, 2.89 acres of Deering Pond will be filled and approximately 1,200 -eet of the Silvermine River will be relocated to support the highway embankment.

(DESCRIPTION OF WOR.. CONTINUED ON PAGE 1-A)

Project Location:

In Norwalk River

At Norwalk, Connecticut

Pormit Conditions:

Oeneral Condition:

1. The time limit for completipg the work suthorized end on 31 December 1991 . If you nnd that you aced more time to complete the authorized activity, submit your requeat for a time extonsion to this ofnes for conelderation at leart one month before the sbove date is reached.

2. You mut malatuin the ectivity authorized by this permit in good condtion and in conformace with the tarme and coadt. tions of this jermit. You are not relleved e" this requirement if you abandos the pomalted activity, although you may make - good futh transfor to a thled party in complience with Generd Condition 4 bolow. Bhould you whe to casen to waintaln

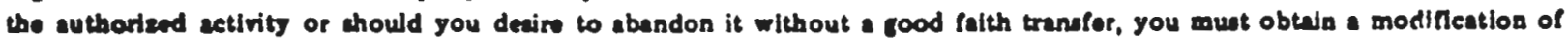
thib parralt from this office, whleh may require restoration of the ares.

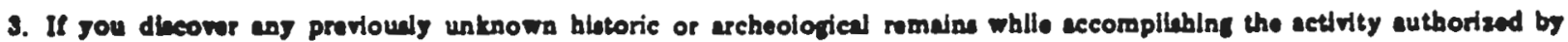

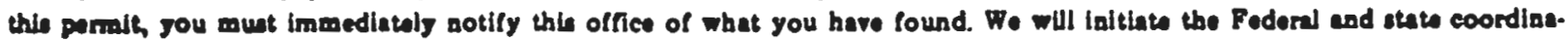

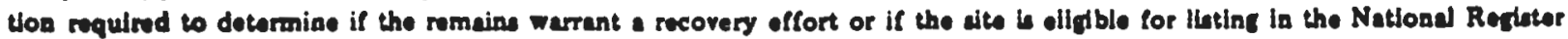
of Hitorie Blecen.

ENo FonM 1721, Mer es

EDITION OF SEP O2 IS OBSOLETE.

(39 CFR 328 (Appendix A)) 


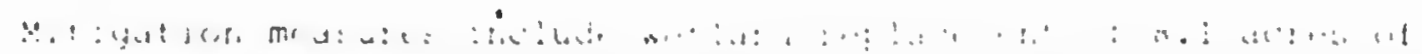

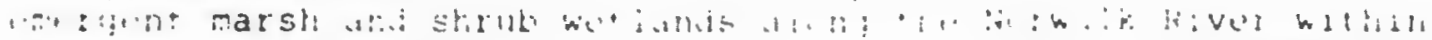

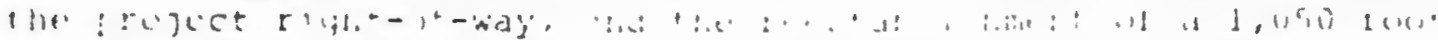

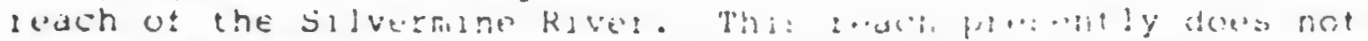

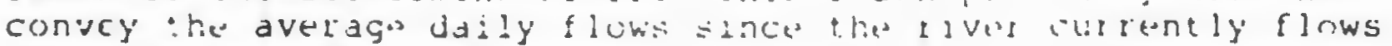

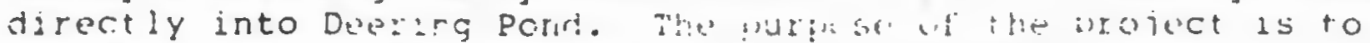

provide dequate survice to the traviling publis: 1 h the Norwalk

area and better access to the Merrit Parkway.

Site 1

This site is located between the Norwdlk River and existing southbound on-ramp to Route 7. just south of New Caanan Avenie. At this site a 1.1 acre emergent marsh and shrub wetland will be created by excavation, deposition of a minimum of 12 " of organic substrate, planting 258 of the area with shrubs, and seeding the area with herbaceous emergent vegetation.

Site 2

At this site, the Ruute 7 mainline will cross Deering Pond, causing fill encroachment into 2.9 acres of the pond. A $171^{\prime}$ bridge consisting of two $85.5^{\prime}$ spans and a center pier support will be built over the river. An upland animal passage way, and two shallow emergent habitat areas will be constructed on both sides of the embankment.

Site 3

This site is located east of Riverview Drive between Broad Street and Perry Avenue at the Silvermirie River. Approximately 1,200 feet of the existing channel will be filied or abandoned, and approximately $890^{\circ}$ of new channel will be constructed. The new channel will consist of a $30^{\circ}$ bottom width for low flows which is desiqned to create a meandering thalweo. Riffle and pool complexes will be incorporated into the channel. In addition. the original (now abandoned) streambed of the silvermine River, west of Deering Pond, will be restored as a mitigation. A 1,050 foot reach of the river will be the new permanent low-flow channel.

Site 4

The construction of the eastbound and westbound detour roads and :amps will rejuire filling of $i .24$ acres of wetlands. These wetlands are located near the Merritt Parkway overpass of Perry Avenue. The three wetlands are located northwest, northeast and southedst of the crossing of these two roads. A wetland creation area will be constructed at site 4 totalling 0.60 acres. 
$\therefore 1 \cdot 5$

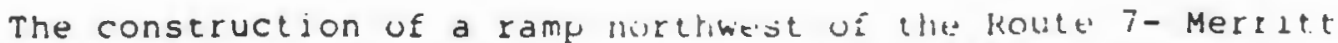
parkway intercharae will necesslicis the filling of 0.94 acres of wetlands, consisting of about 0.62 acies of wooded swamp and 0.32 acres of marsh. The impacted wetland system consists of three small interconnect.ed wetlands.

Site 6

This site is located north of the Merritt Parkway near Louden Street. Two wetlanci parcels will be impacted by the construction. North of Louden Streat, ramp construction will impact 0.40 acres of wetland. South of Louden street, the ramp will impact 0.29 acres of wetland. A new drainage system under the ramps will also be installed.

Site 7

This site is located along the NUSCO power lines between Louden street and Seir Hill Road. A total of $4.10 \mathrm{acres}$ of wetland will be filled for the construction of Route 7. Two wetland creation areas, totalling approximately 3.8 acres, will also be constructed at site 7 .

\section{Site 8}

The Route 7 project will require relocating Oakwood Avenue to the west of the new highway. The north edge of a small wetland will be filled to accommodate this relocation. The total wetland area impacted is approximately 0.15 acres, comprised of shrub and wooded swamp.

\section{Site 9}

Wetland impacts at this site consist of three wetland areas. Approximately 0.38 acres of wooded swamp between Oakwood Avenue and Glover Avenue will be filled by the Route 7 embankment. The highway construction and relocated Grist Mill Road will necessitate the filling of 0.18 acres of wooded swamp. The third wetland fill area is near the intersection of Oakwood Avenue and Grist Mill Road. The relocation of Grist Mill Road will result in the filling of 0.3 acres of wooded swamp.

Site 10

This mitigation site is located north of Deering Pond along the east side of the proposed Route 7 highway. The mitigation will consist of two creation areas. The northern area will total 0.70 asres and will initially be utilized as a sedimentation basin. Following construction, it will be cleaned out and vegetated to create an emergent marsh wetland. South of Perry Road, a $200^{\circ}$ long narrow rlprap and grass drainage swale will be constructed to divert the highway runoff from the northern marsh wetland to Deering Pond.

$$
1-\mathbf{B}
$$


4. If you sell the roperty asociated with this permit. you rrust oblain the sugnalure of the new uwner in the opace growided and forward a copy of the permit to this sffice to validate the tranafer of this authorization.

8. If a conditioned wator quality certification has been iesued for your project, you muat comply with the conditione ipecified In the certification se special cunditione to this permit. For your convenience, a copy of the certification is atiached if it con. Leir: such conditions.

6. You must ellow ropresentatives from this offen to inspect the suthorized activity at any time doemed necousry to ensure that it is boing or hew boen accomplished in accordence with the terma and conditions of your permit.

8pectal Condition:

$$
\text { (SPECIAL CONDITIONS LISTED ON PAGE 4) }
$$

Further Information:

1. Congmalonal Authoritie: You have been suthorized to undertake the estivity described above punuant to:

? ) Bection 10 of the Rivers and Harbors Act of 1899 (33 U.S.C. 403).

(X) Bection 404 of the Clean Water Aet (33 U.S.C. 1344).

( ) Bection 103 of the Marine Protection, Research and Sansiuariea Act of 1972 (33 U.8.C. 1413).

2. Limite of this suthorization.

2. Thlo pormit dow not obviate the need to obtuin other Fediral, alse, or locul euthorization required by lew.

b. This pormit doen not grent any proparty right or exclunive privileges.

c. Thle perwit dow not authorize eny injury to the property or elichts of othere.

d. This pormit dow sot authorize Interference with any existing or propoced Federal project.

5. Limite of Fedord Llability. In inuing this parmit, the Federd Govemment does not anume any liability for the following:

2. Damagen to the pesanitted project or usen thereoi an a result of ocher permitted or unpermitted ectivities or from anturd causes.

b. Dameges to the permitied project or uees thereof a a resulf of curreat of futire activities undertaken by or on bahalf of the Unitod gtate in the publle Interent.

e. Damenes to person, property, or to other permitied or unpermitted activities or atructures cauned by the setivity autborised by thit pormit.

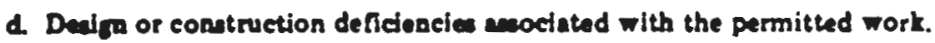




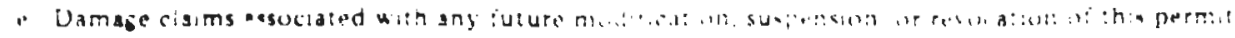

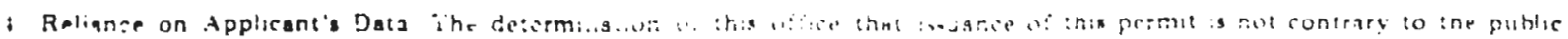
interes: wa made in reliance on the information siou provided

5 Reraluation of Permit Decision. Thi offin me." peavaluate th accioion on this nermit at any time the circumatances warrant. Circumatances that could require a reevaluation incluoe, but are not limited to, ihe following

- You fait to comply with the terms and conditions of this permit

b. The information provided by you in upport of your permis application proves to have been ralse, incomplete, or incecurate (Bee $\$$ above).

c. Significent new information surfaces which this office did not consider in remching the original public interest decision.

8uch a reevaluation may result in a determination that it is appropriate to use the suspension, modification, and revolation procedures contained in 33 CFR 325.7 or enforcement procedures auch at thove containod in 33 CFR 323.4 and 826.5 The referenced erforcement procedures provide fur the iseunce of an adminiatrative order requiring you to comply with the terma and condition of your permit and for the Initiation of legal action where appropriats. You will be roqulred to pay for any corrective mesuret ordered by this office, and if you fujl to comply with such directive, thls offles may in certaln aituntions (euch en those epecined in 33 CFR 209.170) accomplish the corrective mesures by contract or otherwlee and blll you for the cont.

6. Extenulon. Oenord condition 1 erebilahee a time limit for the completion of the ectivity suthortzed by this permit. Undme there are circumutence requiring either a prompt completion of the authorized activity or a seevaluntion of the publle Intareat jecidon, the Corpe will normally give favorable consideration to a requeat for nn exte:sion of thle time liant.

Your algature below, a permittes, indleates that you eccept and arree to comply with the torme and conditlon of thle parmit.

This perfnit becomes offective when the Federal official, designeted to act for the Secretary of the Army, bes aimed below.

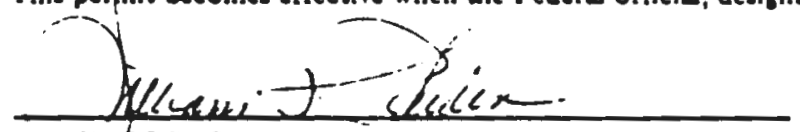

(DISTRCT LNGINEEK)

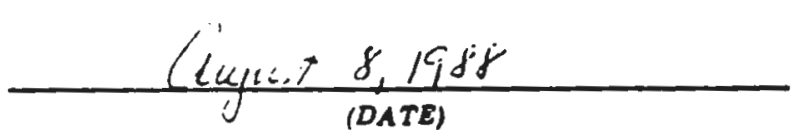

i stanley J. Murphy, LTC

- Corps of Engineers

When the atructures or work authorized by this permit are still in exintence at the time the property is tranaterred, the terms and cor dition of this permit a .' coatinup to be biading on 4.2 new owner(a) of the property. To validate the transfor of this permit and the anocistad liabilities anociated with complience with its term and condition, have the trantores sim and dato bolow. 
DEPARTMENT OF THE ARMY PERMIT

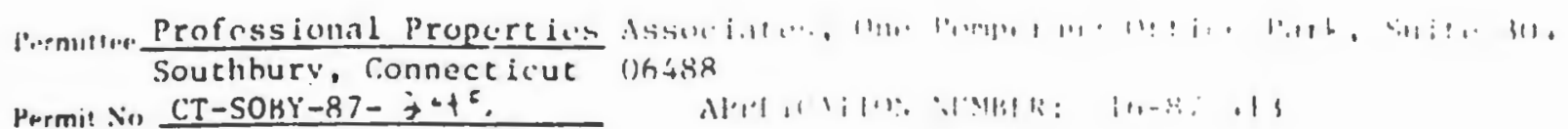

Issuing orrice New Fngland Division

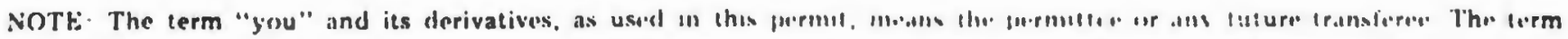

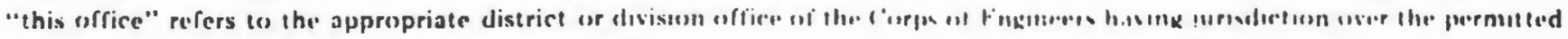

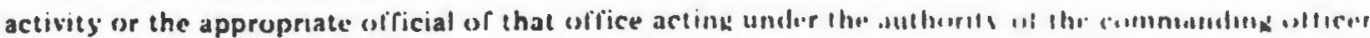

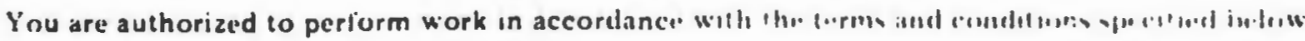

Project Drscription :

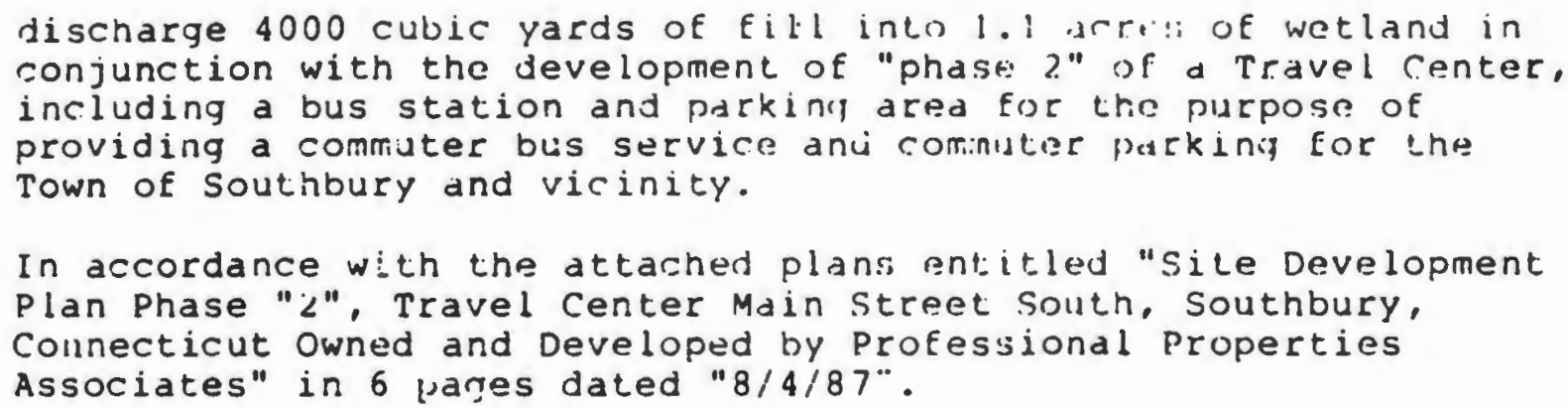

Project Location:

Southbury, Ct at the southwest conner of Connecticut Routr 172 and Main Strest South.

Permit Conditions:

General Conditions:

1. The time limit for completing the work authorized unds on December 31, 1990 If you find that you need morr lime tu omplete the authorized activity. subnil your request for a time extencion to this office for consideration at least one month before the above date is reached.

2. You must maintain the activity authorized by this permil in kood condition and in conformence with the terms and condi. tions of this permit. You are not pelieved of this requiremint if yuu abariJon the permitted astivity. although you may make - guud faith l.m.nsfer to a third party in a smpliance with Gelleral Condition $t$ below. Should you wish. to cease to maintain the suthorized activity or should !nu desire t) abandon it without a good faith transfer, you must obtain a modification of this permit from this office, which mav requirc resturation of the area.

3. If you discoser any previnusly unknown historic or archeoluxical remains while accomplishils the activity authorized by this permit, you must immediately notify this oflice of what you have found. We will initiate the federal and state coordina. tion required to determine if the remaths harrant a recovers effort or if the site is eligible for listing in the National Register of Historic Places 


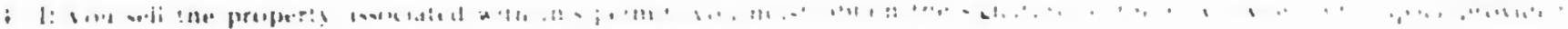

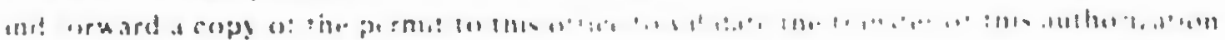

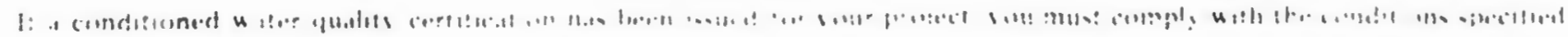

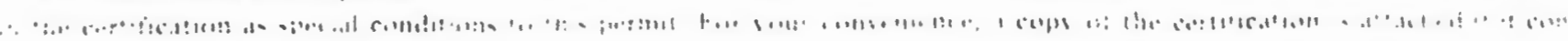

$1, .11,-$ urs conditims

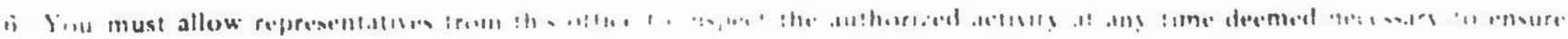

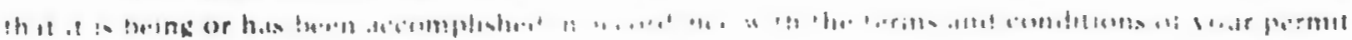

Sipectos linstritus.,

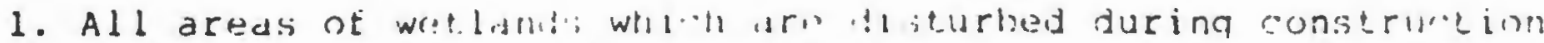
shall be resturei to kmir mproxinale orisinal elevation lbi:

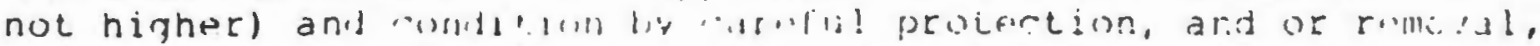
and replacement of "uist.tm soil and vegetation. In addition, if

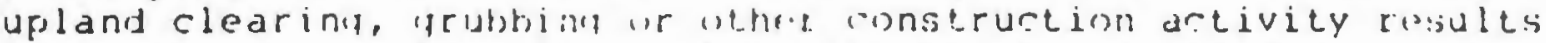
in or may result in soil arosion with transport and deposition into wetland, devire!s ill!h d.: hay bales, sediment trenches, etc.. shall be installord alll proprerly maintained to minimize such impacts during constru'tiun. These devices must be removed when no longer needmi.

Further Intormation. (EPECIAL, CONDITIONS CONTINUED ON PAGE 4)

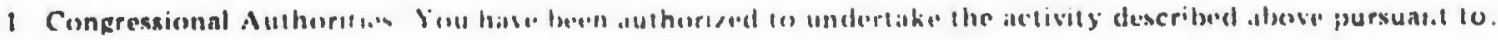

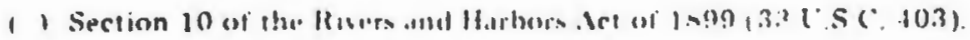

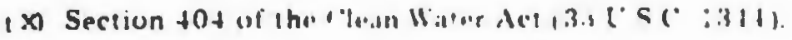

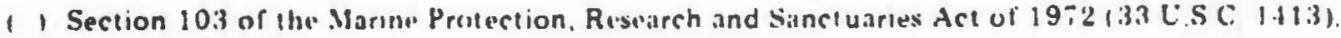

2 Linits of this authorizatıın

a. This permit does not obviate the reed to obtan uther Federal, state. or local authoieaturn required by law

b. This permit does not grant any propert! rents or : xclusise privileges

c. This permit does nui authorize any injury to the property or rights of others

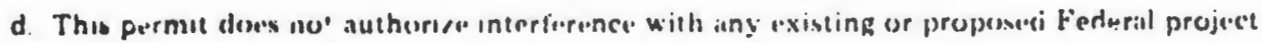

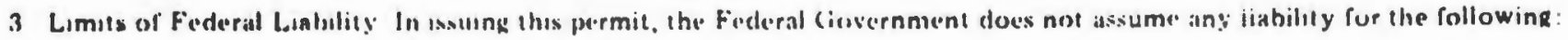

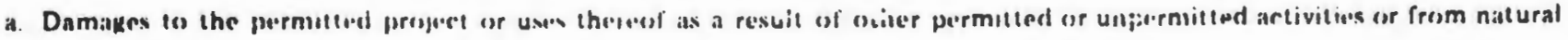
raum's

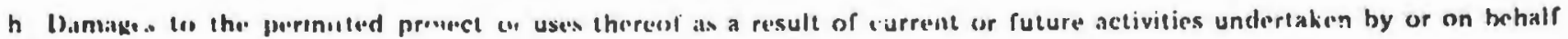
of the Linited stales is the puhlile interens.

c. Damises to pencons, property, or to other permitted or unpermilled activities or structuriss caused by the activity authoriead by this permil.

d. Disign our construction deficiencies assuciated with the permitted work. 


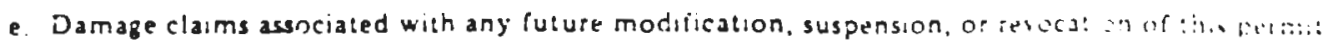

4 Reliance on Applieant's Dala: The determination of this office that isuance of this neritus, nub cuniraty the the publis interest was made in reliance on the information ;ou provided.

5. Reevaluation of Permit Decision. This office may reevaluste it decizion on this permit at any ame the circumstance" worrant. Circumstances that could :equire a reevaluation include, but are not limited to, the following

- You fail to comply with the terma and conditiona of this permit.

b. The information provided by $j, j$ in suppor: of your permit application proves to have been false, incomplete, or ineccurate (See 4 abovi).

c. Simificant new information aurfaces which this office did not consider in reaching the original public intrest decision.

Buch a reeraluation may result in a delemination that it is appropriate to use the supenaion, moditication, and revocotion procedures contained in 33 CFR 325.7 or enforcement procedures such ss those contsined in 33 CFR 328.4 and 328.6 . The referenced enforcement procedures provide for the isuance of an adminiatrative order requiring you to comply with the Lerms and condition of your permit and for the initiation of legal action where appropriate. You will be required to pay for any corrective meaures ordered by this office, and if you fail to comply with auch directive, this office may in certain .ituations isuch se those specified in 33 CFR 209.170) sccomplinh the corrective messures by contract or otherwise and bill you for the en.

6. Extenion. General condition 1 eatablithes a time limit for the completion of the activity authorized by this permit. Unleos there are circumstances requiring sither a prompt completion of the authorized ectivity or a reevaluation of the publlc intereat decision, the Corps will normally give favorable consideration to a requeat for an extencion of this time limls.

Your aignature below, a permittee, indicates that you accept and agree to comply with the torms and condltions of this permit. PROFESSIONAL PROPERTIES ASSOCIATES, INC.

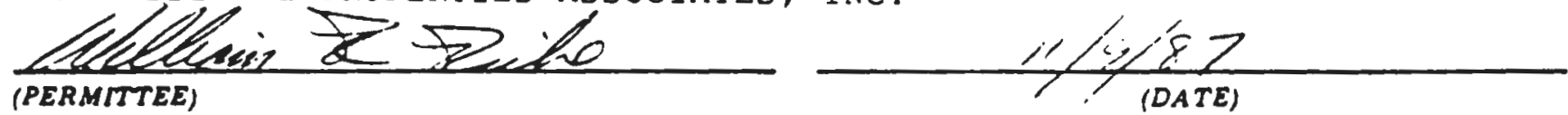

This pepmit becomes effective when the Federal official, designated to act for the Secretary of the Army, has signed below.

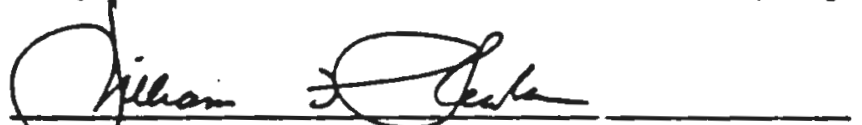

(DISTH(ICT ENGINEER)

\section{Nen 1982}

(DATE)

STANLEY J. MURPHY, LTC. CORPS OF ENGINEERS

When the structures or work authorized by this permit are still in existence at the time the property is transfered, the terms and conditions of this permit will continue to be bincing on the new owner(s) of the property. To validate the tranufer of this permit and the asociated liablities asociated with compliance with its terms and conditions, have the transferee sign and date below. 
BIBLIOGRAPHY 


\section{BIBLIOGRAPHY}

Ammann, Alan P. and Amanda Lindley Stone. Method for the Comparative Evaluation of Nontidal Wetlands in New Hampshire. Concord, NH: New Hampshire Department of Environmental Services, March 1991.

Association of Wetland Mangers, Inc. 1985. Proceedings: National Wetlands Assessment Symposium. Vermont: Association of Wetland Mangers.

1986. Proceedings: National Wetland Symposium. Mitigation of Impacts and Losses. Vermont: Association of Wetland Mangers.

Baldwin, Malcolm F. 1987. "Wetlands: Fortifying Federal and Regional Cooperation." Environment. Volume 29, Number 7, September 1987.

Bennett, Kyla. 1991. Wetland Specialist, U.S. Environmental Protection Agency, Region 1. Personal Communications, 6/17/91, 7/11/91, $7 / 17 / 91,7 / 25 / 91$, and 7/26/91.

Burke, David G., et. al. 1988. Protecting Nontidal Wetlands. APA PAS, Chicago: American Planning Association.

Council on Environmental Quality. 1988. Special Report: Conclusions and Recommendations of the Council on Environmental Quality Regarding the Use of Wetlands Creation to Mitigate Wetlands Impacts. March 1988.

Cowardin, L.M., V. Carter, F.C. Golet and E.T. LaRoe. 1979. Classification of Wetlands and Deepwater Habitats of the United States. Washington D.C.: U.S. Fish and Wildlife Service.

Dahl, T.E. 1990. Wetlands Losses in the United States 1780's to 1980's. Department of the Interior, Fish and Wildlife Service, Washington, D.C. 21 pp. 
Dumanoski, Dianne. 1989. "Nature not easy to match." The Boston Globe. Monday, August 14, 1989.

Gwin, Stephanie E., and Mary E. Kentula. 1990. Evaluating Design and Verifying Compliance of Wetlands Created Under Section 404 of the Clean Water Act in Oregon. Corvallis, Oregon: US EPA Environmental Research Laboratory. July 1990.

Hall, Eric. Water Quality Specialist, US Environmental Protection Agency, Region 1. Personal Communication on May 5, 1992.

Herke, Scott W. Regulatory Wetland Specialist, US Army Corps of Engineers - New England Division. Personal Communication $7 / 92$.

Howland, William. 1989. "Wetlands." Lake Champlain Committee Newsletter. Summer/Fall 1989.

Kriz, Nancy. 1988. "Is Wetlands Creation Effective Mitigation?" New England Environmental Network News. Fall 1988.

Krohe, James Jr. 1989. "When It Comes to Wetlands, There's Nothing Like the Real Thing" Planning. Chicago: American Planning Association, February, 1989.

Kusler, Jon A. 1990. Wetlands Creation and Restoration. The Status of the Science. Washington DC: Island Press.

1987. Wetland Restoration/Creation: A Science Perspective. A Draft Discussion Paper, 10/21/87.

Larson, Joseph. 1986. Mitigating Freshwater Wetlands in the Glaciated Northeast United States: An Assessment of the Science Base.

1987. Wetland Creation and Restoration: An Outline of the Scientific Perspective. Presented at the National Wildlife Federation Symposium "Increasing Out Wetland Resources," Washington, D.C., October 5, 1987.

Lyons, Janet. 1989. Walking the Wetlands, a Hiker's Guide to Common Plants and Animals of Marshes, Bogs, and Swamps. United States: John Wiley and Sons, Inc. 
Mantell, Michael A., et. al. 1990. Creating Successful Communities: A Guidebook to Growth Management Strategies. Washington DC: Island Press.

Mitchell, John H. Introduction. Life in and Around Freshwater Wetlands: A Handbook of Plant and Animal Life In and Around Marshes. Bogs, and Swamps of Temperate North America East of the Mississippi. New York: Thomas Y. Crowell Company, 1975.

Mitsch, William J. and James G. Gosselink. 1986. Wetlands. New York: Van Nostrand Reinhold.

Niering, William A. 1989. The Audubon Society Nature Guides: Wetlands. United States: Alfred A. Knopf, Inc.

Office of Technology Assessment. 1984. Wetlands: Their Use and Regulation.

Pontius, Frederick, W. 1990. "Federal Laws Protecting Wetlands." Journal AWWA.

Reimold, Dr. Robert J, and Sue A. Cobler, of Metcalf \& Eddy, Inc. 1986. Wetlands Mitigation Effectiveness. US EPA. February 1986

Salvesen, David. 1990. Wetlands, Mitigating and Regulating Development Impacts. Washington D.C.: The Urban Land Institute.

Shields, Pamela. 1985. "Report on Success Rates of Wetland Creation for Mitigation." EPA Memo to Douglas Thompson, EPA Region 1 Wetlands Coordinator. April 27, 1985.

Smith, Brian R. 1989. "Wetlands Regulation and Enforcement: A Perspective for Developers." Robinson \& Cole. The Law and The Land. Connecticut: Robinson \& Cole.

Stevens, William K. 1991. "Restoring Lost Wetland: It's Possible But Not Easy." The New York Times. Tuesday, October 29, 1991.

Thompson, Douglas A. and Ann H. Wiliams-Dawe. Key 404 Program Issues in Wetland Mitigation. US EPA - Region 1. No Date. 
Tiner, R.W. 1988. America's Wetlands. Our Vital Link Between Land and Water. Washington, D.C.: U.S. Fish and Wildlife Service, February 1988.

- 1989. Wetlands of Rhode Island. U.S. Fish and Wildlife Service, National Wetlands Inventory, Newton Corner, MA. 71 pp. + Appendix.

United States Army Corps of Engineers, New England Division. 1989. Evaluation of Freshwater Wetland Replacement Projects in Massachusetts. Massachusetts: Department of the Army. December 1989.

United States Department of the Interior. 1984. "Wetlands of the United States: Current Status and Recent Trends." National Wetlands Inventory. March 1984.

United States EPA. 1988. America's Wetlands: Our Vital Link Between Land and Water. February 1988.

1988. "Wetlands." Environmental Backgrounder. Washington D.C.: Office of Public Affairs, November 1988.

1987. New England's Wetlands: An EPA Strategy for Protection. February 1987.

1981. New England Wetlands, Plant Identification and Protective Laws. Washington D.C.: U.S. Government Printing Office, May 1981.

- Wetlands Protection. No Date.

United States Fish and Wildlife Service. 1989. Federal Manual for Identifying and Delineating Jurisdictional Wetlands. January 1989.

Weller, Milton W. 1987. Freshwater Marshes: Ecology and Wildlife Management. Minneapolis: University of Minnesota Press.

Wood, Duncan. Goldberg, Zoino \& Associates (GZZ), a Consulting Firm that worked on the Rockingham Mall Project. Personal phone communication on August 28, 1991. 